1982

\title{
Excavations at Sites 41LK31/32 and 41LK202 in the Choke Canyon Reservoir, South Texas
}

Robert F. Scott IV

Center for Archaeological Research

Daniel E. Fox

Center for Archaeological Research

Follow this and additional works at: https://scholarworks.sfasu.edu/ita

Part of the American Material Culture Commons, Archaeological Anthropology Commons, Environmental Studies Commons, Other American Studies Commons, Other Arts and Humanities Commons, Other History of Art, Architecture, and Archaeology Commons, and the United States History Commons

Tell us how this article helped you.

This Article is brought to you for free and open access by the Center for Regional Heritage Research at SFA ScholarWorks. It has been accepted for inclusion in Index of Texas Archaeology: Open Access Gray Literature from the Lone Star State by an authorized editor of SFA ScholarWorks. For more information, please contact cdsscholarworks@sfasu.edu. 


\section{Excavations at Sites 41LK31/32 and 41LK202 in the Choke Canyon Reservoir, South Texas}

\section{Creative Commons License}

\section{(c) (1) \&}

This work is licensed under a Creative Commons Attribution-NonCommercial 4.0 International License 


\title{
EXCAVATIONS AT SITES 41 LK $31 / 32$ AND 41 LK 202 IN THE CHOKE CANYON RESERVOIR, SOUTH TEXAS
}

\author{
Part I: Prehistoric Investigations \\ by Robert F. Scott IV
}

Part-II: Historic Investigations by Daniel E. Fox

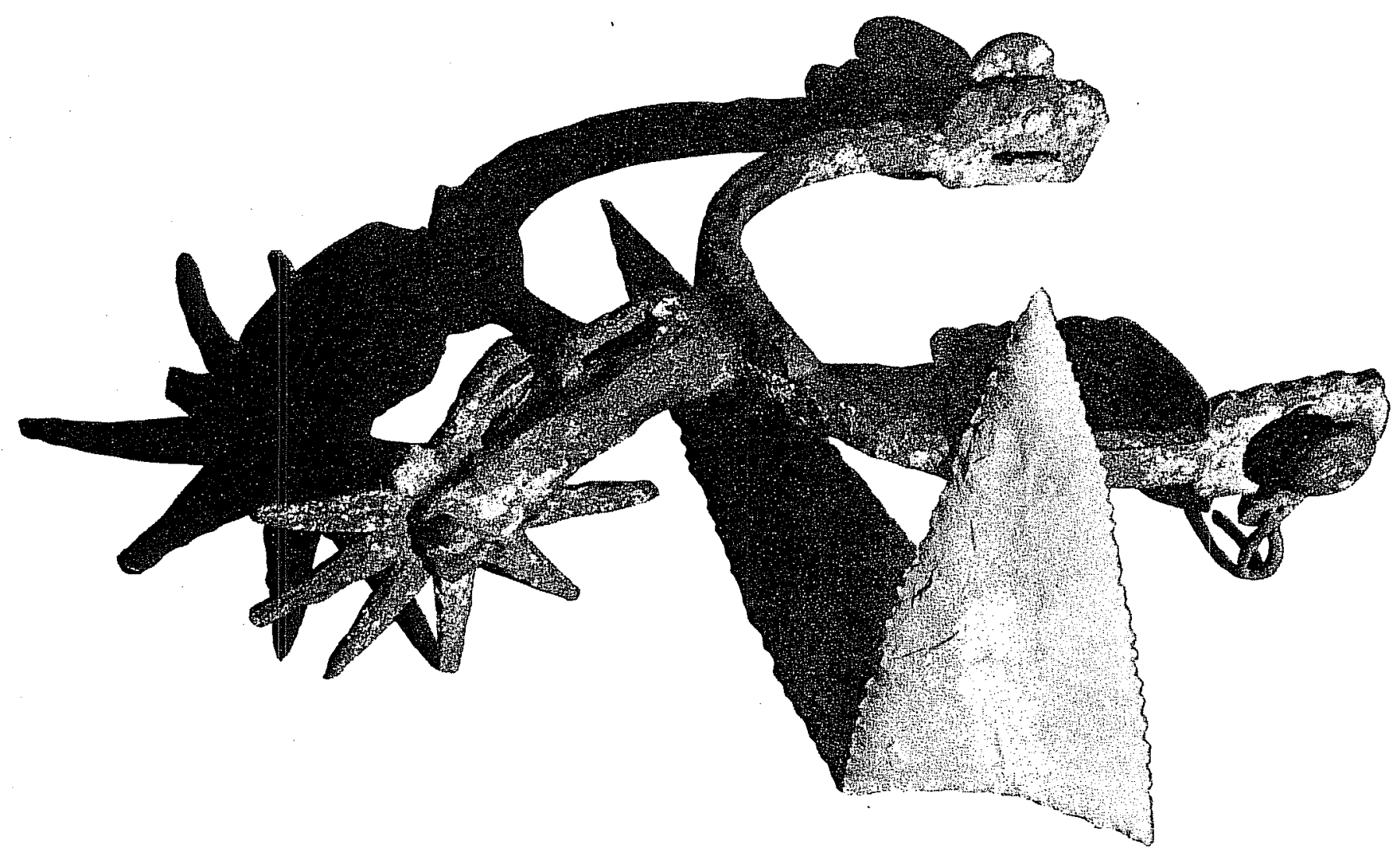

Center for Archaeological Research

The University of Texas at San Antonio

Choke Canyon Series: Volume 8 


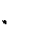


Center for Archaeological Research

The University of Texas at San Antonio

78285

Thomas R. Hester, Director

Volumes in the Phase I Choke Canyon Series.

Volume 1 Historic Indian Groups of the Choke Canyon Reservoir and Surrounding Area, Southern Texas. By T. N. Campbe11 and T. J. Campbe11.

Volume 2 Part I - Historical Resources of the Choke Canyon Reservoir Area in McMullen and Live Oak Counties, Texas. By Dianna Everett.

Part II - Historical Archaeological Resources of the ChokeCanyon Reservoir Area in McMul len and Live Oak Counties, Texas. By Philip A. Bandy.

Volume 3 An Archaeological Survey of a Portion of the Choke Canyon Reservoir Area in McMullen and Live Oak Counties, Texas. By Alston V. Thoms, John L. Montgomery, and Alice W. Portnoy.

Volume 4 The 1979 Archaeological Survey of Portions of the Choke Canyon Reservoir in Live Oak and McMullen Counties, Texas. By Erwin Roemer, Jr.

Volume 5 Archaeological Investigations at Choke Canyon Reservoir, South Texas: The Phase I Findings. By Grant D. Ha11, Stephen L. Black, and Carol Graves.

Volume 6 Archaeological Testing and Collecting at Choke Canyon Reservoir, Nueces River Project, Texas. By Carol S. Weed and Harry J. Shafer.

Volume 7 Excavations at 41 LK 67, A Prehistoric Site in the Choke Canyon Reservoir, South Texas. By Kenneth M. Brown, Daniel R. Potter, Grant D. Ha 11, and Stephen L. Black.

Volume 8 Excavations at Sites 41 LK $31 / 32$ and 41 LK 202 in the Choke Canyon Reservoir, South Texas. By Robert F. Scott IV and Daniel E. Fox.

Volume 9 Phase I Archaeological Investigations at Choke Canyon Reservoir, South Texas: A Summary and Synthesis. By T. R. Hester and Grant D. Ha11.

NOTE: Titles of the above volumes are tentative and may change at time of publication. 


\author{
EXCAVATIONS AT SITE 41 LK $31 / 32$ \\ AND 41 LK 202 IN THE \\ CHOKE CANYON RESERVOIR, SOUTH TEXAS
}

PART I: PREHISTORIC INVESTIGATIONS

by Robert F. Scott IV

PART II: HISTORIC INVESTIGATIONS

by Daniel E. Fox

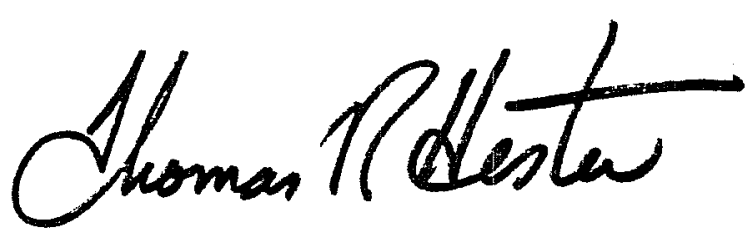

Thomas R. Hester

Principal Investigator

Center for Archaeological Research

The University of Texas at San Antonio

Choke Canyon Series: Volume 8

1982 



\section{ABSTRACT}

Site 41 LK $37 / 32$ is located in Live Oak County, southern Texas on a wide horseshoe bend of the Frio River, approximately $16 \mathrm{~km}$ west of the Frio's confluence with the Nueces River. Construction of the Choke Canyon Reservoir by the Bureau of Reclamation (USBR) had necessitated an excavation program at the site prior to destruction. Investigations conducted by the Center for Archaeological Research, The University of Texas at San Antonio, were carried out in two stages, culminating in a major excavation during the summer of 1978. An indication of the depth and significance of cultural deposits at the site occurred in 1977 when the Bureau of Reclamation dug a series of $9 \mathrm{~m}$ deep geological test pits. Prehistoric occupation zones beginning at a depth of 2.5 meters and continuing to the surface were exposed. The coincidental location of necessary dam ingredients--specific clays and gravel and the site-prompted testing and, later, intensive excavation by the Center for Archaeological Research. Artifacts and depositional information derived from the field work established 41 LK $31 / 32$ as the location of intermittent occupation by hunting and gathering peoples for more than 5000 years stretching from the Early Archaic through the Late Archaic.

KEYWORDS: archaeology, south Texas, Live Oak County, Archaic, Historic. 
ABSTRACT ..........................

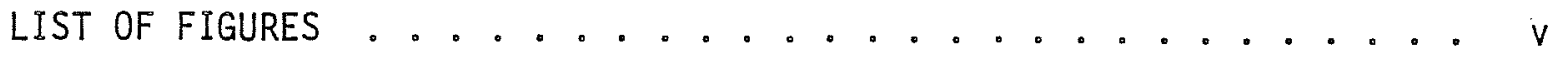

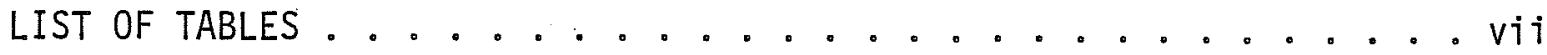
ACKNOWLEDGMENTS .............................

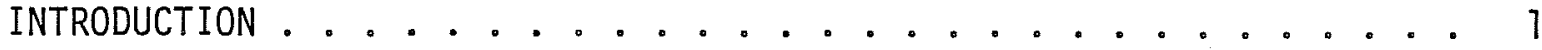
PART I: PREHISTORIC INVESTIGATIONS ............ 5 ETHNOHISTORIC BACKGROUND ............... . . 7

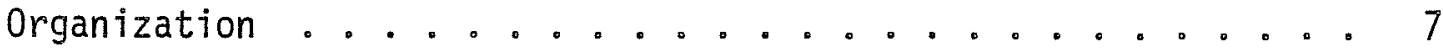
Seasonal Movements ................. 8

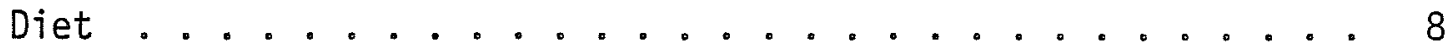

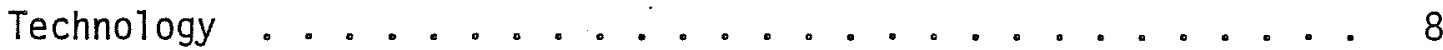

CONTEMPORARY ENVIRONMENT AND GEOLOGICAL SETTING . . . . . . . 9

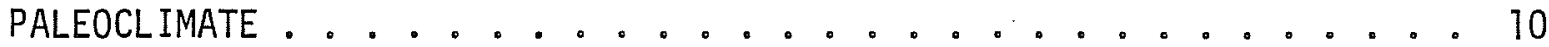
EXCAVATION METHODOLOGY ................ 12 STRATIGRAPHY AND SOILS ............... 16

Soil Samples .................... 17

Soil Monoliths ................... 20

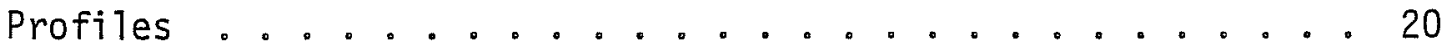

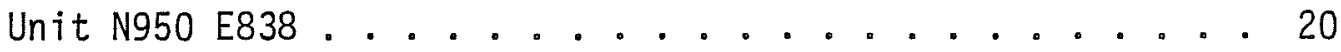

Units N1094 E998 and N1116 E998 .............. 21

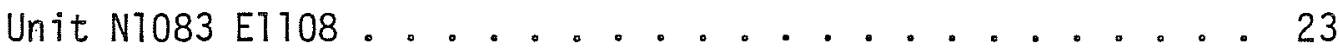

$\mathrm{TPC}-364 \ldots \ldots \ldots 25$

Summary ...................... 32

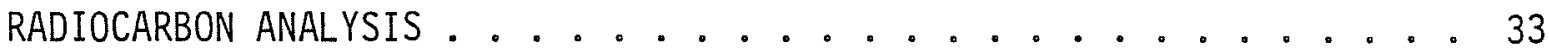


Page

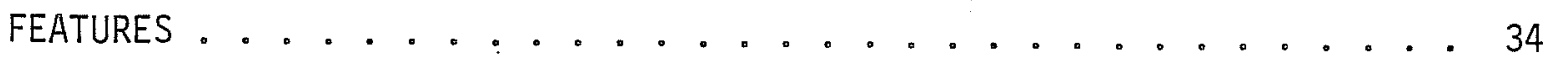

Feature Descriptions ................ 36

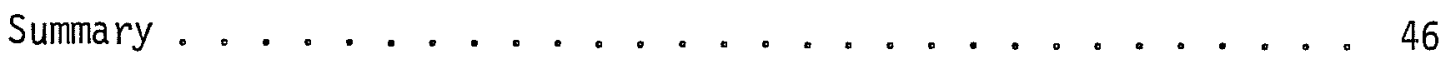

ARTIFACT ANALYSIS ......................... 47

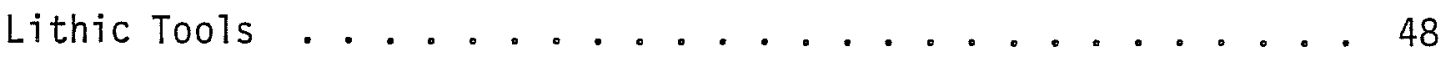

Cores ........................... 48

Thick Bifaces .................. 54

Thin Bifaces.................... 59

Distally Beveled Bifaces and Unifaces ....... 70

Debitage Analysis .............. 73

Ground Stone Artifacts . . . . . . . . . . 77

FAUNAL ANALYSIS . . . . . . . . . . . . 79

SNAIL SHELL ANALYSIS................. 81

MUSSEL SHELL ANALYSIS .............. 81

INTERPRETATIONS AND SUMMARY OF PREHISTORIC OCCUPATION AT 41 LK 31/32 • 82

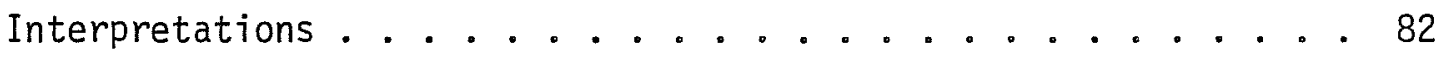

Horizontal Distributions . . . . . . . . . 83

Subsistence Strategies ........... 85

Hester-Collins Mode1 ............ 87

Chronological Implications ............ 88

Summary .................... $89^{\circ}$

PART II: HISTORIC INVESTIGATIONS . . . . . . . . . . 91

HISTORIC SITES INVESTIGATIONS ................. 93

Historic Component at 41 LK $31 / 32 \ldots . . . . . . . . ~ 93$

Historic Component at 41 LK 202 . . . . . . . . . . . . 97

Site Histories . . . . . . . . . . . . . . 97 
Analysis of Historic Artifacts .......... 102 Construction Materials . . . . . . . . 102 Food-, Medicine-, and Beverage-Related Materials . . . 109 Household Items ................ 112 Harness Trappings and Agricultural Equipment . . . . . 175 Personal Items ................... 115 Firearm-Related Items ............... 118 Miscellaneous and Unidentifiable Metal . . . . . . 118 Summary and Interpretations ............ 118

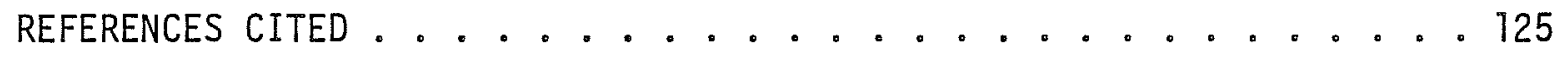

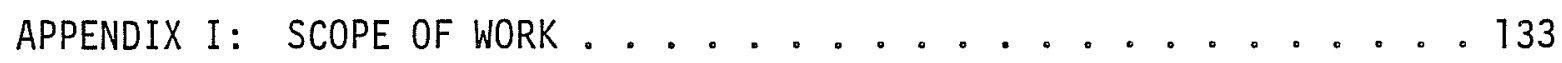
APPENDIX II: RATES OF RECOVERY FOR SELECTED CLASSES OF DEBRIS BY

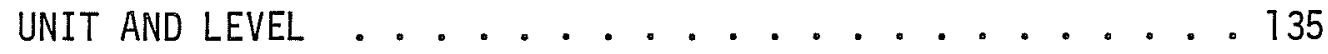

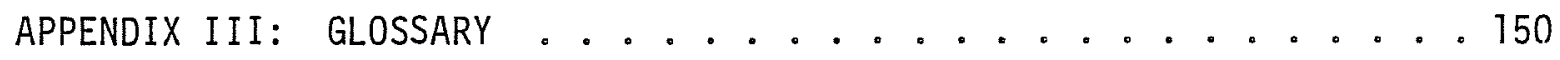




\section{LIST OF FIGURES}

Page

1. Views of $41 \mathrm{LK} 31 / 32 \ldots \ldots 2$

2. Frio River Valley Environmental Zones ......... 11

3. Extent of Sites, Unit and Trench Locations, and Local Topography .............. . . 14

4. Soil Profiles; East Wall of Units N1094 E998 and N1716 E998 along E1000 Line ............... 22

5. North Wal1 Profile--N1083 E1108 ........... 24

6. General Photos--Prehistoric . . . . . . . . 27

7. General Photos--Prehistoric ........... 29

8. Plan View of Zone 2 Features ................ 31

9. 41 LK 31/32 Feature Thickness and Relative Stratigraphic Position 35

10. Plan View and Cross Section of Feature 10 . . . . . . 40

11. Plan View and Cross Section of Feature 11 . . . . . . 41

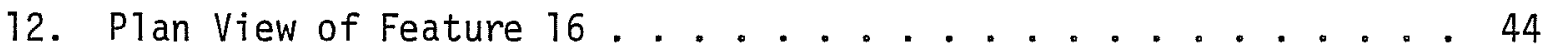

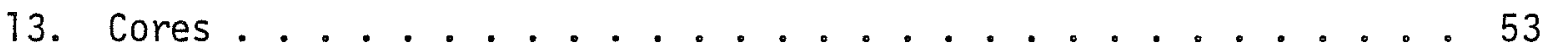

14. Thick Bifaces ............... . . 57

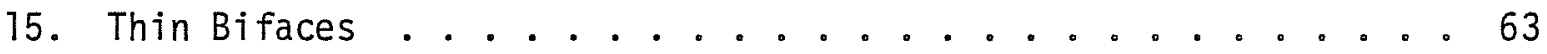

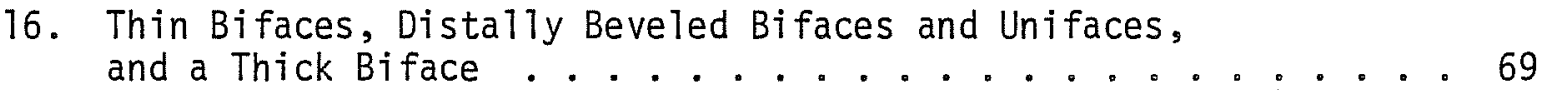

17. General Photos--Historic . . . . . . . . 95

18. 41 LK $31 / 32$ Historic Component--PTan Map

19. 41 LK 202 Historic Structure--Plan View and Excavations . . . . 100

20. Metal Items and Construction Materials . . . . . 103

21. Food-, Medicine-, and Beverage-Related Materials ..... 111

22. Historic Ceramics .............. 113 


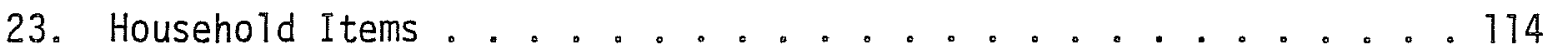

24. Harness Trappings and Mower Blade Fragment ........ 116

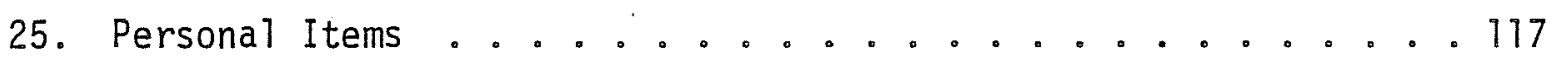
26. Firearm-Re1ated Items . . . . . . . . . 119 27. Sketch of Historic Sites Reconstructed .......... 120 
Page

1. Chemical Soil Anatysis ................... 18

2. Summary of Radiocarbon Dates .............. 34

3. Provenience of Cores Recovered in Excavations ....... 50

4. Provenience and Metric Data of Thick Bifaces ....... 55

5. Provenience and Metric Data for Stemmed Thin Bifaces .... 60

6. Provenience and Metric Data for Unstemmed Thin Bifaces Recovered in Excavations ....... 64

7. Provenience and Metric Data for Distally Beveled Bifaces and Unifaces ............... 71

8. Provenience and Metric Data for Ground Stone Artifacts . . . 78

9. Vertebrate Fauna .............. 80

10. Identified Mussels from 41 LK $31 / 32 \ldots \ldots 82$

11. Chronology of Historic Sites 41 LK $31 / 32$ and 41 LK 202 . . . 98

12. Historic Artifacts from 41 LK 202 and 41 LK 31/32 ..... 104 


\section{ACKNOWLEDGMENTS}

The successful completion of this project required numerous people performing dozens of tasks in the field and during analysis. I am particularly indebted to a field crew which performed under cruel weather conditions and maintained their professionalism at all times. They are: Cristi Assad, David Ayers, David Brown, Will Day, Curtis Dusek, Margarita Vazquez Dusek, Jane Laurens, Rick Hubbard, Daniel R. Potter, Cindy Slayton, and Don White. Bob Stiba's help as Field Assistant deserves a special note of thanks.

Volunteers provided much needed help in the closing days of the project. Al McGraw, Fred Valdez, Mary Ann Slayton, and Janet Stock provided this extra help.

Bob Oram of the Bureau of Reclamation was a major help in the necessary dealings with construction schedules and bureaucratic questions.

The often tedious process of sorting, cataloging, and analyzing the excavated materials fell to Lynn Highley, Janet Stock, and Daniel R. Potter. Mary Lou Ellis and Karen Scott adeptly administered office matters and helped keep people and equipment in the field.

Dr. Thomas R. Hester supplied suggestions, literature, and sage advice throughout the project, as well as considerable patience in dealing with the manuscript. Likewise, Grant D. Hall's help, advice, and consultation were vital to the project. His initial work at 41 LK $31 / 32$ delineated the importance of the site and established procedures followed in later investigations.

Daniel E. Fox analyzed material remains from the historic sites and did the necessary historical background research. Karen Scott aided in research, as well as supplying patience far beyond the call of duty.

Bil1 Fawcett and Dr. Charles Reher of the University of Wyoming provided source material and stimulating conversations on the occupations at 41 LK $31 / 32$. Karen Bridger, also of the University of Wyoming, assisted in critical, 1astminute drafting duties.

Dr. Thomas R. Hester, Sharon Quirk, Lynn Highley, Al Wesolowsky, and Mary Lou Ellis assisted in editing the manuscript. Typing was done by Pat Wallace. 


\section{INTRODUCTION}

Sites 41 LK 31 and 41 LK 32 were first recorded by the Coastal Bend Archaeological Society (CBAS) in February 1972. Both sites were described as prehistoric lithic scatters* occupying a low terrace east and south of a bend in the Frio Riven (Fig. 1,a). This locale was on the Schwartz estate, roughty $12 \mathrm{~km}$ west of Three Rivers, Texas. 41 LK 31 had surface evidence that included dart point fragments, burned chert, 7 ithic debitage, and freshwater mussel shells according to the CBAS records. Testing was recommended. Site $41 \mathrm{LK} 32$, roughly $400 \mathrm{~m}$ east of 41 LK 31 , was likewise subjected to surface collection by the CBAS. Lithic debitage, mussel she11, and burned chert were noted and collected. This site was not felt to be of extensive occupational duration and consequently was not recommended for further work or testing. Plowing and grazing had disrupted the surface over parts of both 41 LK 31 and 41 LK 32, although roughly half of 41 LK 31 remained wooded (Fig. 1,b).

The Cultural Resources Institute (CRI) of Texas Tech University, under subcontract with the Center for Archaeological Research. The University of Texas at San Antonio (CAR-UTSA), conducted more extensive surveys as specified under Phase I survey requirements (Contract No. 7-07-50-V0897). By the time the CRI had surveyed the area, the Bureau of Reclamation had excavated several deep geological test pits in search of clay and gravel deposits. Among other geological test pits, one each had been placed on 41 LK 31 and 41 LK 32. The pit designated by the Bureau of Reclamation as TPC-364 revealed that an extensive cultural zone lay buried some $2 \mathrm{~m}$ below ground surface in the vicinity of $41 \mathrm{LK} 31$. Several additional cultural zones were noted, between $35 \mathrm{~cm}$ and $2 \mathrm{~m}$ depth, with associated chipped stone, mussel she1l, and burned rock. In particular, a thick, dark cultural zone at approximately 2 m deep was felt to be significant in light of the scarcity of such buried occupations in the reservoir area. TPC-363, in the middle of 41 LK 32, showed the same buried cultural zones, particularly the thick, dark horizon also noted at 41 LK 31. Similar exposures of mussel shells, burned rocks, and lithic debitage to at least $2 \mathrm{~m}$ were also noted. Knowledge of the burned materials led to the modification of the site's evaluation as an extensive surface scatter to that as one with considerable depth and potential for contributing to the prehistory of south Texas. Additionally, the exposure of continuous subsurface cultural zones allowed the site numbers to be combined into 41 LK 31/32, more correctly describing the unified nature of the site.

A previously overlooked historic ruin was discovered in a wooded area on the southwest edge of $41 \mathrm{LK} 31 / 32$ during the testing phase. Bottle glass, foundation stones, and a collapsed chimney marked the smal1 19th century structure. No separate site number was awarded it, as it was felt the structure actually represented the final episode of the prehistoric-historic continuum, and as such, rightfulty should be considered a part of 41 LK $31 / 32$.

The Bureau's designation of the area occupied by 41 LK 31/32 and 41 LK 202 (a historic site located $250 \mathrm{~m}$ south of $41 \mathrm{LK} 31 / 32 * *$ ) as a primary borrow area

*A "Glossary" is included as Appendix III to this report. $\star \star 41$ LK 202 was initially recorded by CRI; see Thoms, Montgomery, and Portnoy 1981 for background information. 
Figure 1. Views of 41LK31/3Z. a, aerial photo; $b$, site contour map.

PAGE 16 REDACTED 
for fill in the Choke Canyon Dam necessitated immediate attention to the sites. Both sites had been accorded sufficient merit to undertake extensive subsurface excavation to retrieve all information possible prior to destruction.

Field work under Contract No. 7-07-50-V0897 began in late January 1978 by personnel from the CAR-UTSA (Appendix I). The duration of the field work was spent in testing 11 sites, six of which were located on the Schwartz property and included 41 LK $31 / 32$ and 41 LK 202. A series of 44 backhoe trenches across 41 LK $31 / 32$ helped confirm the continuous and unified nature of the subsurface deposits, while two hand-excavated $3 \times 4-\mathrm{m}$ test units revealed the existence of at least four distinct prehistoric cultural horizons ranging from Early Archaic to Late Archaic. Radiocarbon assays from two features yielded absolute dates of 3380-3350 B.C. from the deepest cultural horizon, and 23602340 B.C. (MASCA corrected) from a cultural horizon roughly $1 \mathrm{~m}$ below ground surface. Further work at the site resulted in placement of vertical controls and an east-west baseline running the length of the site, sketching wall profile segments in the geological test pits, photographing and describing five cultural features exposed in the walls of the geologic pit, and preparation of a plane table map complete with locations of geological test pits, backhoe trenches, controlled excavation units, and historic remains. In addition, plan mapping and exposure of the collapsed chimneys was undertaken on the historic component of $41 \mathrm{LK} 37 / 32$.

Intensive excavation of 41 LK $31 / 32$ and 41 LK 202 began in late June 1978, under Bureau of Reclamation Contract No. 8-07-5B-V0335. Four 2-m² test units were hand dug and screened to sterile levels in three peripheral areas of $41 \mathrm{LK} \mathrm{31/32}$. A broad area of ten $2-\mathrm{m}^{2}$ hand tests was placed adjacent to the geological test pit on the western section of the site. Excavation in this western area was facilitated by the removal of $1 \mathrm{~m}$ of overburden, providing easier access to the Middle Archaic component. Removal of the cultural material in the upper $1 \mathrm{~m}$ of soil was felt to be justifiable for two reasons: the scattered Late Archaic materials it contained were wel1 represented elsewhere in the Choke Canyon area as well as in the remainder of 41 LK 31/32; and time saved by not having to dig through the overburden was invaluable in exploring the little known Early and Middle Archaic. Additionally, the initial field work had tested these upper levels in the immediate area of extensive excavations.

A total of 20 cultural features was mapped during both phases of field work/excavations of the prehistoric component at $41 \mathrm{LK} \mathrm{31/32}$. These yielded charcoal as well as artifacts and significant cultural clues to the uses of the site. Detailed profiles were drawn to facilitate geomorphological and stratigraphic investigations. Phytolith and soil samples were taken and water screening was employed to maximize recovery of lithic debris in the unusually hard silty-sand. Part of this water screening employed a window screen to facilitate recovery of botanical samples (seeds, charcoal) and small bones. Soil columns from representative locations in the profiles were framed and plasticized, giving a permanent record of the profiles for future use.

Final work on the historic component of 41 LK $31 / 32$ consisted of ful1 exposure and further detailed mapping of one chimney foundation and a series of bisecting $1-m^{2}$ units designed to reveal any remaining floor or foundation. Artifact 
recovery was also done via water screening, again to increase material recovery and decrease time expenditures.

Historic site 41 LK 202 was extensively tested. Both chimney foundations were cleaned and mapped, six $2-\mathrm{m}^{2}$ test units were excavated and hand screened, and detailed foundation mapping was executed. Artifacts recovered, as well as historic archival research, allowed for a detailed study of the historic occupation. 
Part I: Prehistoric Investigations by Robert F. Scott IV 



\section{ETHNOHISTORIC BACKGROUND}

We have little in the way of ethnohistoric records for the Indians of south Texas. If not for Cabeza de Vaca's misfortune of being shipwrecked on the Texas coast in 1528, even our earliest glimpse of prehistoric south Texas would have been lost. Despite the continuing debate over the route of Cabeza de Vaca (Campbel1 and Campbel1 1981) and the interpretation of what he encountered (ibid.; Fawcett 1977; Newcomb 1961), his account remains the earliest document of an aboriginal existence in south Texas.

Newcomb (1961) summarized what was known about the aboriginal populations of south Texas. Summaries of European chroniclers in the area have been presented in Hester (1977, 1980), Hester and Hi11 (1975), Fawcett (1977, 1979), Campbe11 (1975a), and Campbel1 and Campbe11 (1981). While not rejecting the generalizations on the south Texas hunters and gatherers presented in Newcomb (1961), the more recent studies have elaborated more on seasonal movements and subsistence activities. Additional1y, Campbe11 (1975a), Campbel1 and Campbe11 (1981), and Hester (1980) have tried to break away from the concept of grouping al1 Indians encountered in the early contact literature as either Coahuiltecoor Karankawan-related speakers. For example, Hester (1980:39) notes that at least seven languages (including Karankawa and Coahuilteco) were spoken in south Texas in early historic times.

The extent to which early European accounts can be used to reconstruct prehistoric subsistence is a matter of argument. Fawcett $(1977,1979)$ had drawn heavily upon these chronicles in his reconstructions of annual subsistence cycles around the Palmetto Bend (Jackson County) area. Hester (1980) and Campbe11 (1975a) rely on the early accounts as we11, although warning that inaccuracies and bias inherent in the records should serve to temper the reliability with which the prehistoric condition is actually presented.

It is preferable here to discuss a few of the pitfalls in the use of ethnohistoric documents. Initially, the translations themselves are often a source of question, as the clarity and precision of the observed people or event is subject to a strong European bias. Additionally, it is necessary to question how much of a subsistence regime followed by Late Prehistoric hunters and gatherers would have been followed by their Archaic antecedents 1000 years or more before. With climatic data on south Texas still incomplete, but suggestive of one prone to fluctuations, such a question is valid when annual subsistence rounds and adaptive strategies in the Archaic are archaeologically tested.

What is known about aboriginal peoples (or "Coahuiltecans") in south Texas, regardless of linguistic affiliation, can be summarized as follows.

\section{Organization}

Campbe11 (1975b:21) reports that aboriginal groups may have been substantialiy large, approaching 100 people. Members were related patrilineally and group size was probably dictated by resource density. These bands remained autonomous for most of the year, except when bands coalesced during the summer prickly pear season (NewComb 1961:46). Movement from camp to camp is reported 
as occurring every few weeks or less for the Coahuiltecans (ibid.:39) and around every two to three days for the Mariames (Campbe11 and Campbe11 1981:14). Summer was also a time of ceremonies and trade among the Coahuiltecans (Newcomb $1961: 54-55)$.

\section{Seasonal Movements}

This subject has created the most lively debate among the interpreters of the ethnohistoric record. Campbel1 and Campbe11 (1981:14) note that the Mariames inhabited the lower Guadalupe River region during fall, winter, and spring, then moved toward the dense prickly pear areas around the lower Nueces River for summer. The Avavares, exploiting an area more inland than the Mariames, apparently did not synchronize their subsistence cycle very closely with the seasons (ibid.:24), preferring to exploit an area nearer the prickly pear grounds year round.

Spring, at least for the Mariames, was a time when fish could be collected from overbank flood pools. Campbell and Campbel1 (1981:17) also note that fish bones were saved for grinding and consumption. Snails were eaten in the summer (as well as prickly pears) and pecans in the fall (ibid.:17-18). Winter, the season of greatest food scarcity, was dominated by root foods, a search which often sent the women five to eight miles from camp (Campbell and Campbe11 1981:18).

\section{Diet}

In addition to prickly pears, snails, roots, and pecans, Newcomb (1961:41-43) states that a wide variety of plants and insects, bark, soil, and fecal matter were consumed, in addition to small mammals and fish. Big game--deer, antelope, and bison--were taken when available, but perhaps never contributed more than a small overall percentage of yearly protein needs.

Plant foods in general contribute $60 \%$ to $80 \%$ of the normal diet among hunters and gatherers (Lee and DeVore 1968:7). Prickly pear, pecans, and acorns were important, as well as maguey (Agave americana). These plant foods could be processed or stored as necessary (Newcomb 1961:41). Many more plants were undoubtedly consumed, but confirmation of particulars through the literature is difficult.

\section{Technology}

Special emphasis is placed on this portion of ethnohistoric research. Besides residues of certain food items (animal bones, mussel, and snail shells) that survive in sites, it is the technology used in subsistence activities that is most frequently represented in archaeological assemblages. Hester and Hill (1975:22) have defined a Late Prehistoric "tool kit" that included stone tools (bifaces, scrapers, hammerstones, and perforators), modified bone tools, and bone-tempered ceramic vessels. What Cabeza de Vaca's recollections can actually add to this is minimal. Newcomb (1961:44) notes the bow and arrow, 
rabbit sticks, and woven baskets in use. In addition to weapons (ibid.:41), pits, traps, and brush burning were used as hunting techniques.

Food preparation often leaves traces, most commonly the darkened, thermally fractured stones of a cooking hearth or pit. Campbe11 and Campbe11 (1981:19) referred to the Mariames preparing roots in an unspecified pit oven. A similar reference is found for the Cuchendados who inhabited an area in or near southwestern Jim Hogg County (ibid.:39). Green prickly pear pads were prepared in a pit oven. Other food processing activities by the Cuchendados include pounding mesquite beans in ground pits (Campbel1 and Campbel1 1981). Hi11, Holdsworth, and Hester (1972:10-11) present a modern example of yucca exploitation that utilizes above-ground burning.

Shelter receives 1 ittle attention in south Texas ethnohistory. Newcomb (1961:43) mentions temporary shelters of bent saplings covered by reeds or hides among the Coahuilteco. Campbel1 and Campbel1 (1981:16) describe temporary shelters of bent saplings covered by reeds or hides. They also mention a shelter with four main poles, covered by mats, among the Mariames.

Although the early sources may be inadequate for the purposes of the archaeologist, particularly covering foodstuffs and tools, they are nonetheless essential for interpreting archaeological sites. More detailed data for climatic reconstruction is needed in order to understand the context of the shift from the Archaic to the Late Prehistoric. The ethnohistorical information available at present does permit generalizations that could be applied to the portable technology, seasonal exploitation of resources, and band organization of the Archaic. Particulars of adaption to the Archaic environment, however, must be gleaned from continued archaeological investigation.

\section{CONTEMPORARY ENVIRONMENT AND GEOLOGICAL SETTING}

$41 \mathrm{LK} 31 / 32$ is 1ocated $145 \mathrm{~km}$ south of the Balcones Escarpment and $12 \mathrm{~km}$ west of the town of Three Rivers, Texas. It occupies a terrace in a wide bend in the Frio River. The Nueces River, the second largest drainage on the Rio Grande Plain, has its confluence with the. Frio approximately $9 \mathrm{~km}$ southeast of the site. The U.S. Department of the Interior Environmental Statement (1975: $\mathrm{B}-9)$ describes streamflow in the Frio River as produced in large by "erratic and unpredictable storm rainfal1." Flow derived from springs in the area of the Balcones Fault is largely lost through percolation into the Edwards Aquifer (ibid.). Thus, flood runoff, with additions through tributaries such as the Atascosa River, accounts for the major portion of the streamflow.

The Frio River rises approximately $230 \mathrm{~km}$ northwest of the study area in the dissected and eroded southern margin of the Edwards Plateau and south of the Balcones Escarpment. In Live Oak County, the Frio River is underlain by geological deposits in the Jackson Group (Eocene) including the Frio Formation (01igocene clays) and the Catahoula Formation (Miocene) (Se11ards, Adkins, and P1 ummer 1975:677-727; Russe11 Bunker, personal communication). The Catahoula Formation is composed of "continental sands, clays, and pyroclastics interbedded with fluviatile sediments" (ibid.:720). Volcanic ash and tuffs make up the majority of the Catahoula, forming a friable sandstone which outcrops in many places along the Frio River. The Miocene Oakville Formation and its 
gravel deposits of chert, petrified wood, and limestone are prominent in the southeast part of the county approximately $25 \mathrm{~km}$ from the Choke Canyon area (Weeks 1933:457-458). Additional lag gravels, derived from the Edwards Plateau, are interspaced along the Frio River and provide another source of raw Tithic material. Existence of thin deposits of Uvalde gravel were additionally noted in the area by Russell Bunker (personal communication).

Climate on the Rio Grande Plain can be described as semiarid (Johnson 1931), with peak rainfall occurring during late spring and early fall. Across south Texas rainfall averages vary from 25 inches at Corpus Christi in the east to 20 inches in Starr County in the west ( $i$ bid.:42). Rainfall is often spaced by droughts of varying duration, with one recorded from 1947 through 1956 (U.S. Department of the Interior 1975:B-7). Average annual temperature as given in Johnson (1931) is between $70^{\circ} \mathrm{F}$ and $72^{\circ} \mathrm{F}$. Winters are generally mild and summers long and hot.

Today thorn bush vegetation is predominant. Mesquite (Prosopis juliflora), huisache (Acacia farnesiana), and live oak (Quercus virginiana), and other trees are found in riparian zones. Various cacti also abound, among them prickly pear (Opuntia lindheimeri) and tasajillo.

Blair (1950) places south Texas in the Tamaulipan Biotic Province. No less than 61 species of mammals, 36 species of snakes, 19 lizards, 2 land turtles, 3 toads/frogs, and 19 salamanders occur within the Tamaulipan Province (ibid.: 103). Several species of catfish (Ictalurus sp.), drum (Aplodinotus grunniens), and gar (Lepisosteus) live in the river. Freshwater mussel species include Cyrtonaias tampicoensis, Lampsilis anodontoides, Carunculina parva, and Amblema plicata, among others (Harold Murray, personal communication).

Four broad local environments were recognized in the area: riparian, floodplain, valley wall, and upland (Fig. 2). Deciduous trees dominate the riparian zones, including huisache (Acacia farnesiana), oak (Quercus sp.), and ash (Fraxinum berlandieriana). Floodplains were dominated historically by dense stands of mesquite and thorny shrubs broken by open prairie (Inglis 1964:4246). Mesquite, however, represents a recent intrusion into south Texas and was probably not widespread in prehistoric times as today (Hester 1980:34). The eroded valley walls and uplands are covered by dense xeric shrubs and cacti (notably prickly pear). The valley wall represents the eroded margins of Pleistocene terraces. Rich deposits of cherts and silicified woods are available in the Uvalde gravels associated with these low terraces. Access to all of the local environments is possible within a $6 \mathrm{~km}$ radius of $41 \mathrm{LK} 31 / 32$.

\section{PALEOCLIMATE}

One of the goals of the research at Choke Canyon and at 41 LK 31/32 was to enhance what little is known about the paleoclimate of south Texas. Increasing recognition of climate as having regional variability and being punctuated by episodes not characteristic of the long-term trend has necessitated a more careful view of prehistoric hunting and gathering adaptation (Gunn and Mahula 1977). Techniques utilized during excavation of $41 \mathrm{LK} 31 / 32$, including samples extracted for pollen and phytolith research and detailed soil profiles, were aimed at broad coverage of available techniques indicative of past climatic 


\section{FRIO RIVER VALLEY}

ENVIRONMENTAL ZONES
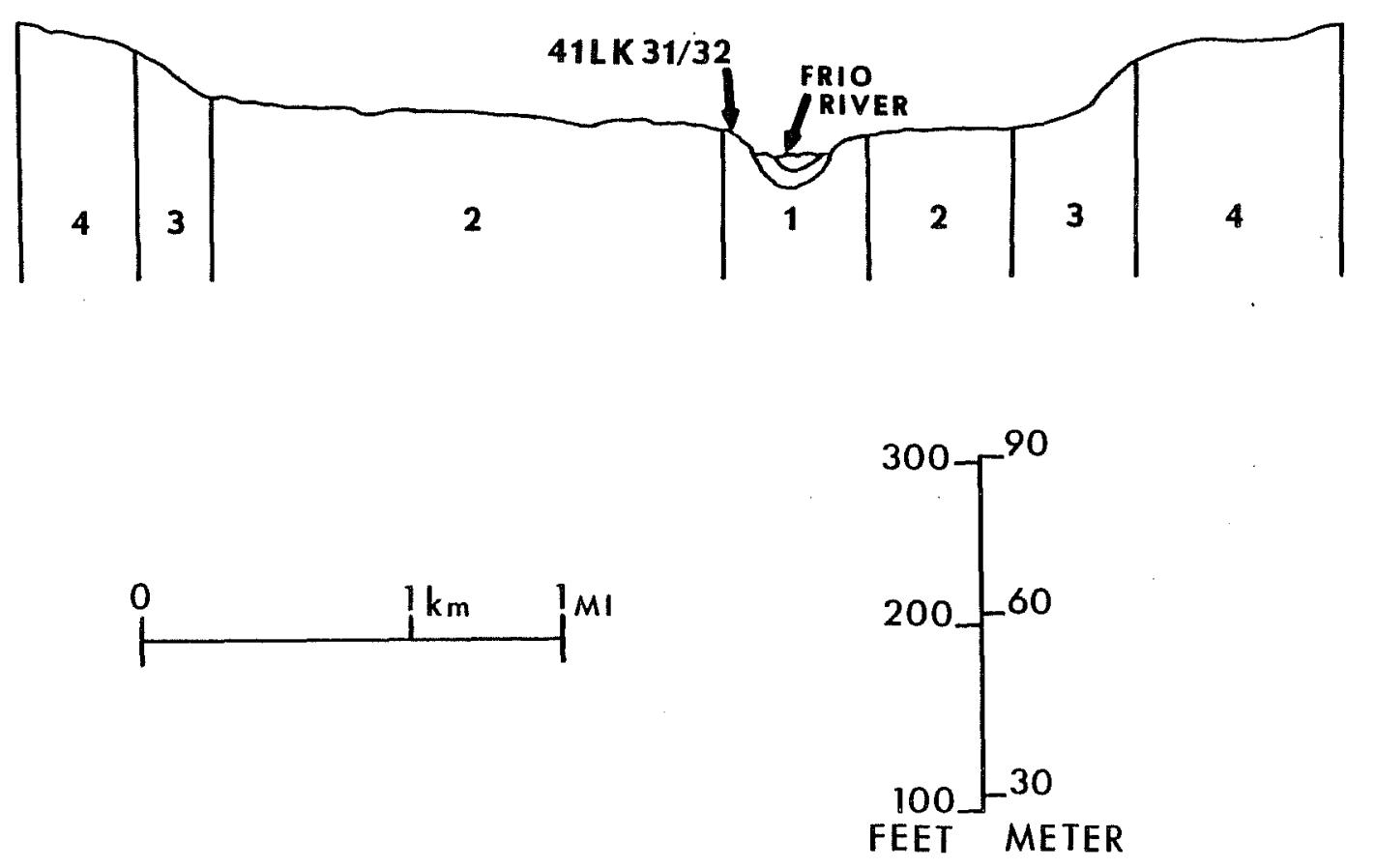

Figure 2. Frio River Valley Environmental Zones. 1-Riparian, 2-Floodplain, 3-Valley Wal1, 4-Upland. 
conditions. Unfortunately, pollen does not preserve well in open sites on the Rio Grande Plain, placing a heavier emphasis on interpretation of the phyto1 ith and sediments.

In general, Texas climate has been growing progressively warmer and drier for the last 10,000 years (Bryant and Shafer 1977). Pollen samples from peat bogs (Bryant 1978) and dry caves (Bryant 1975; Bryant and Shafer 1977) give evidence for this, but apparently not in quantities detailed enough to spot short-term fluctuations. Until techniques of pollen extraction increase in sophistication, alternate methods of analysis, phytoliths for example, hold considerable promise.

Climatic episodes lasting several hundred to several thousand years potentially alter the floral and faunal environment. To what extent is unclear, but phytolith research offers tantalizing clues. At the Hudson-Meng site in Nebraska, use of the silicified (or opalized) plant cells helped identify changing conditions of short grass/tall grass prairie as well as horizontal identification of intersite features (Lewis 1978:211-216). In Texas, Robinson (ms.) has noted a fluctuating climate (wet/dry) with concomitant variation of short/tall grasses and various trees at 41 GD 21 . Unfortunately, comparing the coastal 41 GD 21 with the inland 41 LK $31 / 32$ was not possible at the time of this writing due to incomplete analysis of the 41 LK $31 / 32$ samples.

Indirect archaeological and geological evidence has also contributed to understanding regional climatic fluctuations. Antevs' (1955) suggestion of an Altithermal on the Great Plains from 5500 B.C. -2000 B.C. was an early attempt to identify sporadic climatic change within hemispherical trends. Dillehay (1974) used climatic influences on grasslands to account for shifts in ranges of bison between 10,000 B.C. and 1300-1550 A.D. Three major influxes of the herd animals were accounted for from archaeological evidence in Texas, highlighting the floral and faunal consequences of changes even on the level of several hundred years duration.

Geomorphologically, work by Baker and Penteado-Orellana (1977), Looney and Baker (1977), and Bunker (personal communication) has highlighted climatic fluctuations evidenced in terrace building along the Colorado and Frio Rivers. Baker and Penteado-Orellana (1977) studied the terraces flanking the Colorado River, as well as sediments included in these terraces, for clues about grain size and stream discharge. Their data indicated changes in channel size, meander, and sediments transported during the last 100,000 years of the river's existence. The Colorado River responded to the late Quaternary arid/humid fluctuations which the authors attribute to changes in the Gulf and Continental air masses over central Texas. Bunker's (1982) work at sites along the Frio River suggests that the Rio Grande Plain was under the same influences at the same time.

\section{EXCAVATION METHODOLOGY}

Excavation procedures differed slightly from the limited testing phase to the extensive excavation program contingent upon the goals of each investigation. The necessity of sampling the site and determinating its extent and importance 
dictated the initial testing work, whereas the excavations reported here were specifically designed to extensively document the sites (Fig. 3).

The initial, limited testing (Ha11, Black, and Graves 1982) began with the placement. of horizontal control via the establishment of an east-west baseline running the length of the site. Measurement was determined in meters from this line, eventually extending north and south in addition to being coordinated with the USBR grid system. Location of any given point on the site was then given with a north and east metric coordinate. Two datum points were established for vertical control. Datum 1 was a nail driven into the base of a large mesquite tree roughly $60 \mathrm{~m}$ west of the geological test pit TPC-364,

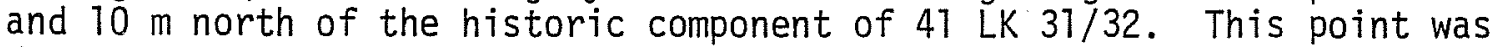
designated an arbitrary $100 \mathrm{~m}$ elevation. Absolute elevation of the datum as determined by the USBR was $50.637 \mathrm{~m}$ above ms 1 . Work on the eastern edge of the site necessitated the placement of a second datum point due to the considerable distance between excavations. Datum 2 was driven into the trunk of a small huisache tree, $25 \mathrm{~m}$ west of geologic test pit TPC-363. Its elevation, relative to Datum 1, was $100.34 \mathrm{~m}$ arbitrary elevation or $50.977 \mathrm{~m}$ above ms 1 .

A series of 44 backhoe trenches was excavated at intervals across the site, eventually sectioning the entire width and breadth of the site (Fig. 3 ). Profiling within these trenches revealed buried features and stratigraphic evidence linking 41 LK 31 and 41 LK 32 as continuous in subsurface cultural evidence. The backhoe trenches were placed in accordance with east-west baseline stakes for the purposes of mapping and testing in the event of a significant feature being exposed. Analys is of stratigraphic information from the backhoe trenches revealed that the heaviest cultural debris (chert flakes, mussel shel1s, snails) occurred in a crescent-shaped area, roughly following the curvature of the present bend in the Frio River. The backhoe trenches indicated the most extensive cultural debris occurred in the upper $100 \mathrm{~cm}$ of deposit between the geologic test pits. The areas adjoining the USBR test pits TPC-364 and TPC-363 indicated deeper deposits of cultural debris, consistent with that noted in the deep profiles of the geologic test pits.

Surveyors from Texas Tech University had originally noted five features occurring in the walls of TPC-364 at 41 LK 31 . A11 of these were described, photographed, and placed on a profile done for four sides of the deep, irregular pit. Eight zones were described from bottom to top of the test pit, with four of the five features occurring in Zone 2, a dark, distinct soil zone some $2.5 \mathrm{~m}$ below ground surface. Radiocarbon samples were collected from the features.

Profiles, drawn as CAR personnel hung hazardously from ropes, were completed for both geologic test pits. The geologic test pit (TPC-363) at 41 LK 32 revealed only 6 gross zonal separations in the pit wall profile, two less than the 41 LK 31 TPC-364 profile. Finer profiles were undertaken during hand excavation of the test units.

Test units were placed over features visible in the geologic pit walls at 41 LK 31 (Fig. 3). Unit N1067 E875 (southwest corner stake coordinate) was placed over Feature 1, a basin-shaped charcoal lens visible in the test pit profile. Dimensions of the test unit were established at $3 \mathrm{~m}^{2}$ to sufficiently encompass the feature and any surrounding cultural debris. To the west of 


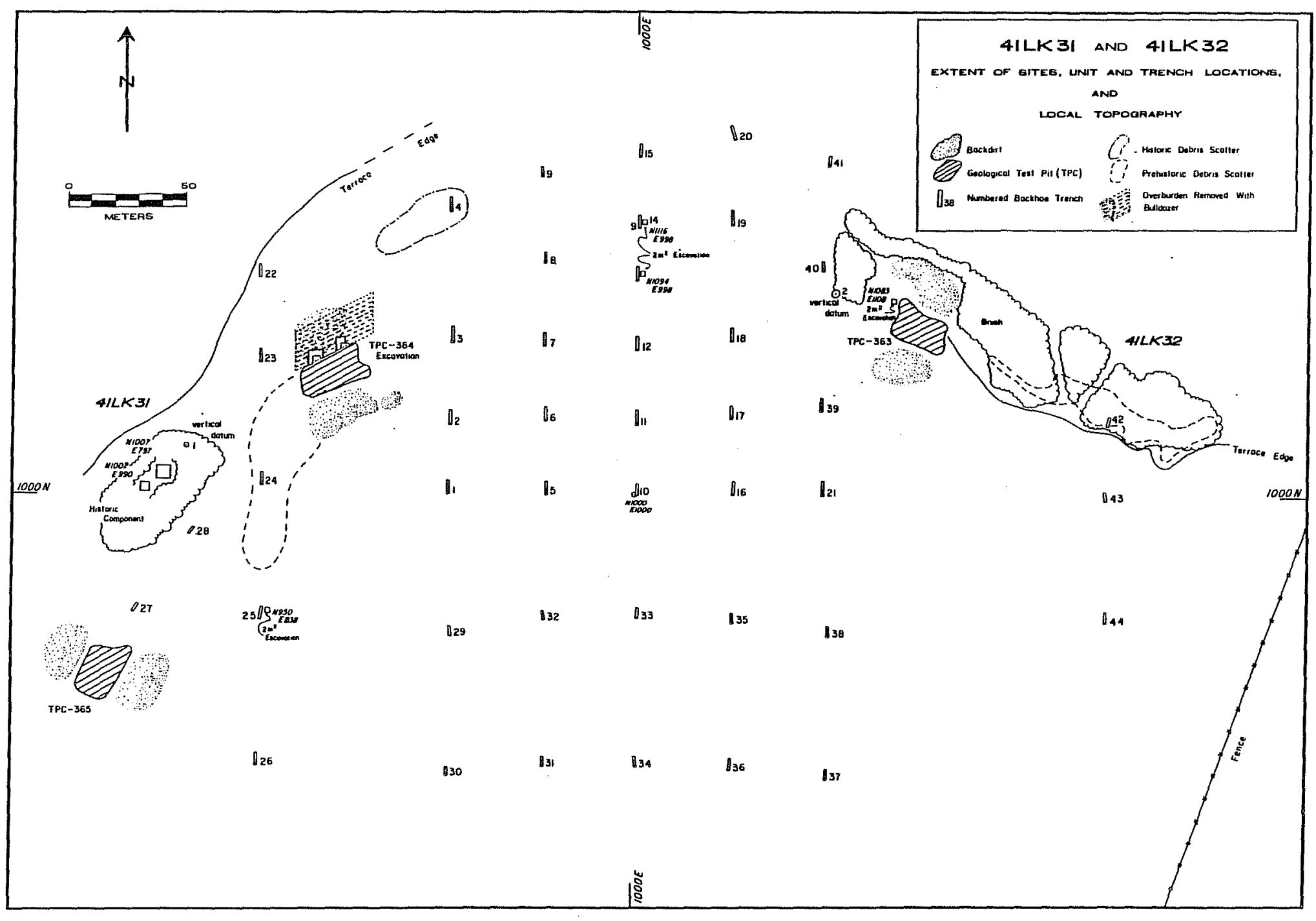

Figure 3. Extent of Sites, Unit and Trench Locations, and Local Topography. 
that unit, Features 2 and 3 were enclosed within the $3-\mathrm{m}^{2}$ boundary of Unit N1056 E863. Both units were established on the north edge of the geologic test pit and suffered from its irregular outline and orientation. Both Units N1056 E863 and N7062 E875 increased in size per level (as the south wal1 slope increased), and eventually involved a $3 \times 4-\mathrm{m}$ unit at a depth of $2.5 \mathrm{~m}$. This problem was dealt with on a level by level basis, and recorded on sketch maps as increases occurred.

Levels were measured in 25-cm increments as excavation began. However, after the completion of level 7 (175 cm below ground surface), thickness was reduced to $10 \mathrm{~cm}$ as it was felt the decreased size would enhance identification of living floors. A brief attempt to excavate in natural levels failed when it became apparent that vertical zone recognition was virtually impossible. This attempt, however, produced a distinct living surface at $225 \mathrm{~cm}$, approximately Zone 4 in the soil profile. When Zone 2, the prominent Archaic leve1, was reached, $3-\mathrm{m}^{2}$ Unit $N 1056$ E863 was subdivided into nine 1-m ${ }^{2}$ units. Each $1-\mathrm{m}^{2}$ unit was then subdivided into four $50-\mathrm{cm}^{2}$ units for excavation in $5-\mathrm{cm}$ levels. It was felt this buried Archaic horizon, a rarity in south Texas archaeology, deserved such detailed scrutiny. After exposure of the cultural remains, size in Unit N1056 E863 was again increased from $50 \mathrm{~cm}^{2}$ to $1 \mathrm{~m}^{2}$ as signs of cultural activity decreased.

Excavated soil was passed through 1/4-inch hardware mesh screens. Unfortunately, time limitations and soil conditions were such that less than 100\% of the actually dug soil was screened. Dryness and soil compaction necessitated constant pulverizing by wooden stakes, a time-consuming and wearisome method. Screens were picked clean of cultural debris prior to full breakdown of soil clods. The vast majority of cultural debris was recovered, however, with any loss being insignificant to the purposes of the mitigation. All 1ithic debitage, burned and unburned rock, mussel shell, snail shell, and stream pebbles were retained for analysis.

Prior to the extensive excavations, the top $1 \mathrm{~m}$ of overburden was removed from an area north of geologic test pit TPC-364 (Fig. 3). Justification for this was felt to be twofold: the initial testing had shown the upper $1 \mathrm{~m}$ of cultural deposits to contain scattered Late Archaic cultural debris, well documented elsewhere in the Choke Canyon Reservoir investigation; time was also a critical factor as the site was situated over essential sands and clays vital for dam construction. The area of heaviest cultural debris, as determined by backhoe trenching, examination of geological test pit profiles, and test excavations was selected and scraped to a depth of $1 \mathrm{~m}$ by a mechanical road scraper. Members of the testing crew monitored the process to maximize data recovery. Eventually an area measuring roughly $30 \mathrm{~m}$ east-west by $15 \mathrm{~m}$ north-south was exposed, encompassing test Units N7056 E863 and N1062 E875.

Generally, our excavation procedures were based on methods deemed to be most appropriate after the initial testing. Three major shifts in methodology distinguished the two excavations: water screening replaced hand screening of soil; a constant unit size of $2 \mathrm{~m}^{2}$ was established, and a constant level of 10-cm increments was used in the scraped area. Units outside of the scraped area, N1083 E1108, N1094 E998, N1116 E998, and N950 E838, were excavated in constant $20-\mathrm{cm}$ levels due to their less complex stratigraphy and lower yield of cultural debris. Additionally, $50 \mathrm{~cm}^{2}$ of soil from each was passed through 
window screen in addition to the 1/4-inch hardware mesh used. Phytolith samples were extracted by a sterile trowel in each 10-cm unit-level in four places, centrally chosen from the four $1-\mathrm{m}^{2}$ subunits enclosed within each $2-\mathrm{m}^{2}$ division. Soil was removed by shovel or with trowels and brushes as features or artifacts were encountered.

Soil profiles were closely detailed for each exposed wall. Records of these profiles were not only drawn, but sampled permanently by plasticizing a soil monolith from a vertical profile section. Six of these monoliths were taken from profiles at 41 LK $31 / 32$ and stored at the Center for Archaeological Research for future use.

A11 material recovered from water screening was retained. After sun drying, the material was sorted and counted for entry onto a field computer form developed by Dr. Joel Gunn of The University of Texas at San Antonio. These forms, coupled with standard unit-level data sheets, helped provide level summaries prior to detailed laboratory recording and analysis.

A11 features were documented by drawings and photographs. Feature fill was also passed through window screens to insure full recovery of small bones, flakes, or seeds. Levels were constantly checked by transit reading.

Finally, all material recovered during excavation was returned to the Center for Archaeological Research at The University of Texas at San Antonio for complete analysis.

\section{STRATIGRAPHY AND SOILS}

Initial excavation of geologic test pits by the Bureau of Reclamation resulted in exposure of graphic soil profiles which, in turn, helped illuminate the importance of $41 \mathrm{LK} \mathrm{31/32}$. The geologic test pits, 10-15 $\mathrm{m}$ in depth, indicated that cultural features and debris extended nearly $2.5 \mathrm{~m}$ below ground surface. In particular, a dark, well-defined soil stratum (later designated Zone 2) appeared to have a preponderance of cultural features and lithic debitage.

Extensive profiling of Bureau of Reclamation test pits TPC -364 and TPC-363 during the testing phase, provided a "road map" of strata which would guide excavations and pose questions for both phases of investigation. Determination of the extent to which cultural activity and riverine flooding influenced the character and evolution of the complex stratigraphic sequence first recognized in the walls of these geologic test pits became one of the major goals of the archaeological investigation at 41 LK 31/32. Coroilary to this objective would be the effort to make inferences concerning paleoclimatic conditions, either local7y or regionally, which may have influenced rates of alluvial deposition as well as prehistoric human activity on the site.

The excavations carried out during the testing phase in Units N1056 E863 and N1062 E875 were initially conducted in arbitrary levels. Below ground surface, a homogeneous deposit of brown to $\tan$ sandy-silt and clay extended to roughly $1 \mathrm{~m}$ in depth. The next 1-1.5 m exhibited a complex sequence of overbank sediments in often discontinuous lenses ranging from light tan to grayish brown in color. It was in this lower $1.5 \mathrm{~m}$ that procedures were briefly 
modified in an attempt to test the feasibility of excavating by natural levels. Unfortunately, this attempt yielded negligible results as the various strata encountered were rarely discernible from the vertical perspective of the excavator and were prone to discontinuity even in the restricted areas excavated. Zone 2 was an exception to this, as it could be readily distinguished by its darker brown hue, block structure, and relative abundance of cultural debris.

Excavating in this manner did suggest that, again with the exception of Zone 2 , darker strata present in the profile were not necessarily associated with cultural activity. This, combined with the difficulty of discerning individual strata during excavation, resulted in the use of arbitrary unit-levels throughout the remainder of the testing phase and continued through the extensive excavation phase.

The test excavations established a stratigraphic sequence that equates the upper meter of soil with the Late Archaic period of occupation and the deeper, complex strata with Early and Middle Archaic occupation. With time considerations for excavation weighing heavily in the decision, the upper meter of soil was removed from an area approximately $30 \times 15 \mathrm{~m}$ adjoining the north boundary of geologic test pit .TPC-364. Loss of Late Archaic materials was felt to be compensated for through gain of additional time to excavate the rarer, wel1stratified earlier cultural remains.

The extensive excavation phase initiated a more extensive investigation of soils and stratigraphy as an extension of earlier findings. Additions of the retrieval of soil samples by zone, the taking of soil monoliths, and the use of a consulting geomorphologist greatly aided in interpreting the depositional and occupational history of the site.

\section{Soil Samples}

After profiles were completed, a soil sample from each identifiable zone was taken; each sample was in excess of $10 \mathrm{~cm}^{2}$ and was extracted for submission to the Texas A\&M Soil Testing Laboratory. Samples were taken from individual units except in the units of the scraped area adjoining TPC-364. Here they were taken from the E861 and N1061 line, and the E873 Tine after excavation ceased.

Particular emphasis was placed on values obtained for phosphorus and organic matter in the chemical soil analysis. Sjoberg's (1976) discourse on phosphates being fixed in soil by human activity was hoped to be found in evidence. However, values of $\mathrm{P}_{2} \mathrm{O}_{2}$ were often found to be the reverse of the expected, falling lower in zones high in cultural debris and higher in zones low on the amount of cultural remains recovered. Organic matter behaved similarly with one notable exception, $N 1176$ E998, exhibiting virtually no variation aside from upper levels. Note Table 1 for summaries of the data.

Deviation from expected variations in $\mathrm{P}_{2} \mathrm{O}_{2}$ and organic matter among levels exhibiting cultural remains might be attributed to sampling narrow vertical areas rather than broad horizontal ones. Unfortunately, the data obtained are incomplete to confirm or refute high counts of organic matter in Unit $N 1116$ E998, Teve1 7, and Unit N1062 E875, Tevel 2. 
TABLE 1. CHEMICAL SOIL ANALYSIS*

\begin{tabular}{|c|c|c|c|c|c|c|c|c|}
\hline Unit & Sample \# & Level/Zone & $\mathrm{pH}+$ & Cas & $\mathrm{P}_{2} \mathrm{O}_{2} \Delta$ & $\mathrm{Fe} \theta$ & $O M_{\pi}$ & $\begin{array}{l}\text { Approximate depth } \\
\text { below datum }(\mathrm{cm})\end{array}$ \\
\hline $\begin{array}{ll}\text { N1083 } & \text { El108 } \\
\text { N1083 } & \text { E1108 } \\
\text { N1083 } & \text { E1 } 108\end{array}$ & $\begin{array}{l}26 \\
27 \\
28\end{array}$ & $\begin{array}{l}2 \\
7 \\
9\end{array}$ & $\begin{array}{l}8.4 \\
8.9 \\
9.0\end{array}$ & $\begin{array}{r}16,400 \\
14,600 \\
110,000\end{array}$ & $\begin{array}{r}181 \\
16 \\
69\end{array}$ & $\begin{array}{l}6.4 \\
9.6 \\
8.4\end{array}$ & $\begin{array}{l}0.6 \\
0.3 \\
0.3\end{array}$ & $\begin{array}{r}40 \\
140 \\
180\end{array}$ \\
\hline $\begin{array}{ll}\text { N11116 } & \text { E998 } \\
\text { N1116 } & \text { E998 } \\
\text { N11116 } & \text { E998 } \\
\text { N1116 } & \text { E998 }\end{array}$ & $\begin{array}{l}29 \\
30 \\
31 \\
32\end{array}$ & $\begin{array}{r}2 \\
5 \\
7 \\
10\end{array}$ & $\begin{array}{l}8.3 \\
8.5 \\
8.5 \\
8.7\end{array}$ & $\begin{array}{r}108,000 \\
20,600 \\
83,600 \\
93,200\end{array}$ & $\begin{array}{r}51 \\
150 \\
114 \\
120\end{array}$ & $\begin{array}{l}6.6 \\
7.2 \\
8.4 \\
5.2\end{array}$ & $\begin{array}{l}0.5 \\
0.4 \\
0.7 \\
0.1\end{array}$ & $\begin{array}{r}40 \\
100 \\
140 \\
200\end{array}$ \\
\hline $\begin{array}{ll}\text { N950 } & E 838 \\
\text { N950 } & E 838\end{array}$ & $\begin{array}{l}1 \\
2\end{array}$ & $\begin{array}{l}2 \\
4\end{array}$ & $\begin{array}{l}8.2 \\
8.5\end{array}$ & $\begin{array}{l}41,800 \\
94,400\end{array}$ & $\begin{array}{r}120 \\
5\end{array}$ & $\begin{array}{l}5.0 \\
7.6\end{array}$ & $\begin{array}{l}0.8 \\
0.4\end{array}$ & $\begin{array}{l}40 \\
80\end{array}$ \\
\hline $\begin{array}{ll}\text { N1062 } & \text { E875 } \\
\text { N1062 } & \text { E875 } \\
\text { N1062 } & \text { E875 }\end{array}$ & $\begin{array}{l}23 \\
24 \\
25\end{array}$ & $\begin{array}{l}1 \\
2 \\
3\end{array}$ & $\begin{array}{l}8.3 \\
8.3 \\
8.4\end{array}$ & $\begin{array}{l}49,200 \\
46,600 \\
96,000\end{array}$ & $\begin{array}{r}181 \\
69 \\
65\end{array}$ & $\begin{array}{l}6.8 \\
6.0 \\
7.8\end{array}$ & $\begin{array}{l}1.3 \\
0.7 \\
0.4\end{array}$ & $\begin{array}{l}10 \\
20 \\
30\end{array}$ \\
\hline $\begin{array}{ll}\text { N1061-2 } & \text { E873 } \\
\text { N1061-2 } & \text { E873 } \\
\text { N1061-2 } & \text { E873 } \\
\text { N1061-2 } & \text { E873 } \\
\text { N1061-2 } & \text { E873 } \\
\text { N1061-2 } & \text { E873 } \\
\text { N1061-2 } & \text { E873 }\end{array}$ & $\begin{array}{r}13 \\
12 \\
11 \\
10 \\
9 \\
8 \\
7\end{array}$ & $\begin{array}{l}10 \\
9 \\
8 \\
6 \\
5 B \\
3 \\
2 B\end{array}$ & $\begin{array}{l}8.6 \\
8.6 \\
8.6 \\
8.6 \\
8.7 \\
8.7 \\
8.7\end{array}$ & $\begin{array}{l}67,600 \\
65,200 \\
67,600 \\
61,600 \\
61,600 \\
71,600 \\
88,000\end{array}$ & $\begin{array}{r}114 \\
87 \\
132 \\
107 \\
132 \\
103 \\
78\end{array}$ & $\begin{array}{l}5.6 \\
5.2 \\
5.0 \\
5.4 \\
5.2 \\
6.4 \\
7.2\end{array}$ & $\begin{array}{l}0.2 \\
0.1 \\
0.2 \\
0.2 \\
0.2 \\
0.2 \\
0.3\end{array}$ & $\begin{array}{l} \pm 140 \\
\pm 155 \\
\pm 145 \\
\pm 160 \\
\pm 180 \\
\pm 200 \\
\pm 220-240\end{array}$ \\
\hline
\end{tabular}

*From Soil Testing Laboratory, Texas Agricultural Extension Service, The Texas A\&M University System. tAcidity or alkalinity $<7=$ acid; $>7=$ alkaline

¿Calcium

$\triangle$ Phosphates

$\theta$ Iron

mOrganic Matter 
TABLE 1. (continued)

\begin{tabular}{|c|c|c|c|c|c|c|c|c|}
\hline Unit & Sample \# & Level/Zone & $\mathrm{pH}+$ & $\operatorname{Ca} \Sigma$ & $\mathrm{P}_{2} \mathrm{O}_{2} \Delta$ & $\mathrm{Fe} \theta$ & $0 M_{\pi}$ & $\begin{array}{l}\text { Approximate depth } \\
\text { below datum }(\mathrm{cm})\end{array}$ \\
\hline $\begin{array}{ll}\text { N1057 } & \text { E861 } \\
\text { N1057 } & \text { E861 } \\
\text { N1057 } & \text { E861 } \\
\text { N1057 } & \text { E861 }\end{array}$ & $\begin{array}{l}3 \\
4 \\
5 \\
6\end{array}$ & $\begin{array}{r}4 \\
9 \\
14 \\
18\end{array}$ & $\begin{array}{l}8.5 \\
8.6 \\
8.6 \\
8.5\end{array}$ & $\begin{array}{l}83,600 \\
63,600 \\
72,400 \\
96,000\end{array}$ & $\begin{array}{r}74 \\
94 \\
78 \\
103\end{array}$ & $\begin{array}{l}7.4 \\
6.0 \\
6.6 \\
8.0\end{array}$ & $\begin{array}{l}0.3 \\
0.1 \\
0.2 \\
0.2\end{array}$ & $\begin{array}{l} \pm 140 \\
\pm 190 \\
\pm 240 \\
\pm 280\end{array}$ \\
\hline $\begin{array}{ll}\text { N1061 } & \text { E866-7 } \\
\text { N1061 } & \text { E866-7 } \\
\text { N1061 } & \text { E866-7 } \\
\text { N1061 } & \text { E866-7 } \\
\text { N1061 } & \text { E866-7 } \\
\text { N1061 } & \text { E866-7 } \\
\text { N1061 } & \text { E866-7 } \\
\text { N1061 } & \text { E866-7 } \\
\text { N1061 } & \text { E866-7 }\end{array}$ & $\begin{array}{l}22 \\
21 \\
20 \\
19 \\
18 \\
17 \\
16 \\
15 \\
14\end{array}$ & $\begin{array}{l}11 \\
10 \\
8 \\
6 A \\
5 \\
4 \\
3 \\
2 A \\
1\end{array}$ & $\begin{array}{l}8.6 \\
8.6 \\
8.6 \\
8.6 \\
8.5 \\
8.5 \\
8.5 \\
8.5 \\
8.2\end{array}$ & $\begin{array}{l}69,200 \\
65,200 \\
66,400 \\
71,600 \\
66,400 \\
74,800 \\
67,600 \\
86,000 \\
89,600\end{array}$ & $\begin{array}{r}120 \\
120 \\
125 \\
114 \\
125 \\
150 \\
120 \\
69 \\
65\end{array}$ & $\begin{array}{l}4.8 \\
5.0 \\
5.6 \\
6.0 \\
6.2 \\
5.0 \\
5.2 \\
6.8 \\
5.4\end{array}$ & $\begin{array}{l}0.1 \\
0.1 \\
0.2 \\
0.3 \\
0.2 \\
0.3 \\
0.1 \\
0.3 \\
0.2\end{array}$ & $\begin{array}{l} \pm 120 \\
\pm 140 \\
\pm 170 \\
\pm 180 \\
\pm 190 \\
\pm 200 \\
\pm 210 \\
\pm 220-240 \\
\pm 260\end{array}$ \\
\hline
\end{tabular}

\footnotetext{
*From Soil Testing Laboratory, Texas Agricultural Extension Service, The Texas A\&M University System. +Acidity or alkalinity $<7=$ acid; $>7=$ alkaline

¿Calcium

$\Delta$ Phosphates

$\theta$ Iron

mOrganic Matter
} 
Soil Monoliths

Five soil monoliths were taken to preserve a permanent soil record. These monoliths were vertical soil columns, 6-8 inches wide, that were plasticized and wood-framed on three sides. After removal, monoliths were stored at the Center for Archaeological Research and examined by Russell Bunker, the consulting geomorphologist. Seven monoliths were taken from three areas of the site and, collectively, represent the range of variation in stratigraphy found across the site.

Russell Bunker (personal communication) was able to utilize the monoliths in grain-size analysis and soil zone correlations. His report (Bunker 1982) notes that 41 LK $31 / 32$ was built by a series of overbank flood sediments composed of sand, silt, and clay. Characteristic settling of these sediments during overbank flooding tended to produce alternating layers of light sand and darker silt and clay layers found at $41 \mathrm{LK} 31 / 32$. This confirms the findings of the testing phase, indicating that cultural activity is not directly linked to observable soil zones.

Soil Zone 2 was only identifiable in two of the soil monoliths (Monolith 1 and Monol ith 5A-5B) according to Bunker (1982). Zone 2 was well-developed soil, which had developed a blocky structure due to longer exposure. Dating of Zone 2 came from Features 1 and 3 , dated at $4710 \pm 80$ B.P. (TX-2920) and $4690 \pm 80$ B.P. (TX-2921), respectively. Cultural debris was also extensive in Zone 2.

\section{Profiles}

Profiles were drawn for at least one wall in each excavation unit. These drawings emphasized the difference in stratigraphy across the site. Generally, the stratigraphic differences ranged from shallow deposits (less than $1 \mathrm{~m}$ to sterile soil labeled Zone 1) on the western edge of the site, to deep complex deposits adjoining TPC -364 , to deep (over $2 \mathrm{~m}$ ) deposits of simpler structure adjoining TPC-363 on the far eastern portion of the site. Zones were not necessarily contiguous across the entire site. Zone 2, for example, could only be clearly distinguished in units excavated in the vicinity of TPC-364. Profiles are summarized below.

\section{Unit N950 E838}

This unit was placed southwest of TPC-364 in an area that had yielded a large number of surface-collected dart points and stone tools (Fig.3). Excavations ceased at a depth of $1 \mathrm{~m}$ (at culturally sterile basal sandy clay), revealing three soil zones containing cultural evidence. A layer of compact gray-brown silty clay extended to roughly a $40-\mathrm{cm}$ depth where it graded into a brown silty clay, less compact in texture. By $60-\mathrm{cm}$ depth the soil had become more consolidated and lighter in color with evidence of caliche formation and a blocky structure. This trend continued to $1 \mathrm{~m}$ at which point excavation ceased. 
Artifacts and lithic debitage occurred from the surface through level 4 of the five-level excavation. Heavy concentrations of chipping debris occurred in levels 2 and 3 , roughly above the point of soil consolidation and the beginning of caliche formation. Soil zones and stratigraphic occurrence of artifacts could not be tightly defined in the vague profiles. Density of lithic debris fell sharply in level 4 and declined to almost nothing by level 5 , at which point excavation ceased.

\section{Units N1094 E998 and N1116 E998}

Placement for these two units (Fig. 3) was determined by the proximity of the area roughly half-way between TPC-364 and TPC-363 on an east-west grid 1 ine. Evidence of deep cultural deposits (in excess of $2 \mathrm{~m}$ below ground surface) occurred in both geological test pits, dictating placement of two central units to test for uniformity in stratification or cultural evidence between the two.

Despite lying on the same grid line (East 998) and only $22 \mathrm{~m}$ apart, the two units were distinctly different and highlighted basic problems encountered at 41 LK 31/32 with discontinuous soil zones (Fig.4). Comparison of the profiles notes the relative lack of complexity throughout Unit N1094 E998 and in the upper $1 \mathrm{~m}$ of Unit N1116 E998. However, the lower meter of the latter unit exhibits a confusing sequence of soil lenses and discontinuous thin strata.

Descriptions of soil zones for Unit N1094 E998 indicates that sandy silt, grading from gray to light tan, occurred from the surface through Zone 3 (approximately $60 \mathrm{~cm}$ below ground surface). Zone 3 was marked by filled intrusions (rodent runs?) and graded into a gray sandy-silt by Zone 4 (Fig. 4). Extending to a depth of $240 \mathrm{~cm}$, Zone 5 was divided by color gradation into subzones $A, B$, and $C$. Soil at this depth exhibited a compact, angular structure and was basically gray in color.

By contrast, soil zones represented in the east wall profile of Unit N1116 E998 showed a somewhat complex process of formation (Fig. 4). Zone 1 graded into Zone 2 as the surface soil of sandy clay and silt graded indistinctly into a blockier, clay-rich layer. Variations in blockiness and clay content marked boundaries between Zones 2 and 3 (approximately $90 \mathrm{~cm}$ below surface) and Zones 3 and 4 (approximately $130 \mathrm{~cm}$ in depth). Zone 5 marked an increase in sandiness which characterized the poorly defined stratification through Zones 11 and 12. Sandiness increased markedly by Zone 11 which extended to a final depth of $270 \mathrm{~cm}$.

Artifact frequency was quite low throughout the excavation of Unit N1094 E998. Fragments of snails and mussel shells were encountered (along with three chert flakes in level 1) until leve1s 7 and 8 when 22 and 10 chert flakes, respectively, were recovered. These levels roughly correspond to the indistinct contact of soil Zones 5A and 5B. Cultura 1 evidence disappeared after level 8 with no recovery in levels 9 or 10 .

Again by contrast, Unit N1716 E998 was quite different from Unit N1094 E998 in subsurface recovery. Land snails were present thoughout, and traces of 1 ithic debris appeared in level 3. Level 5 produced over one dozen chert flakes, 


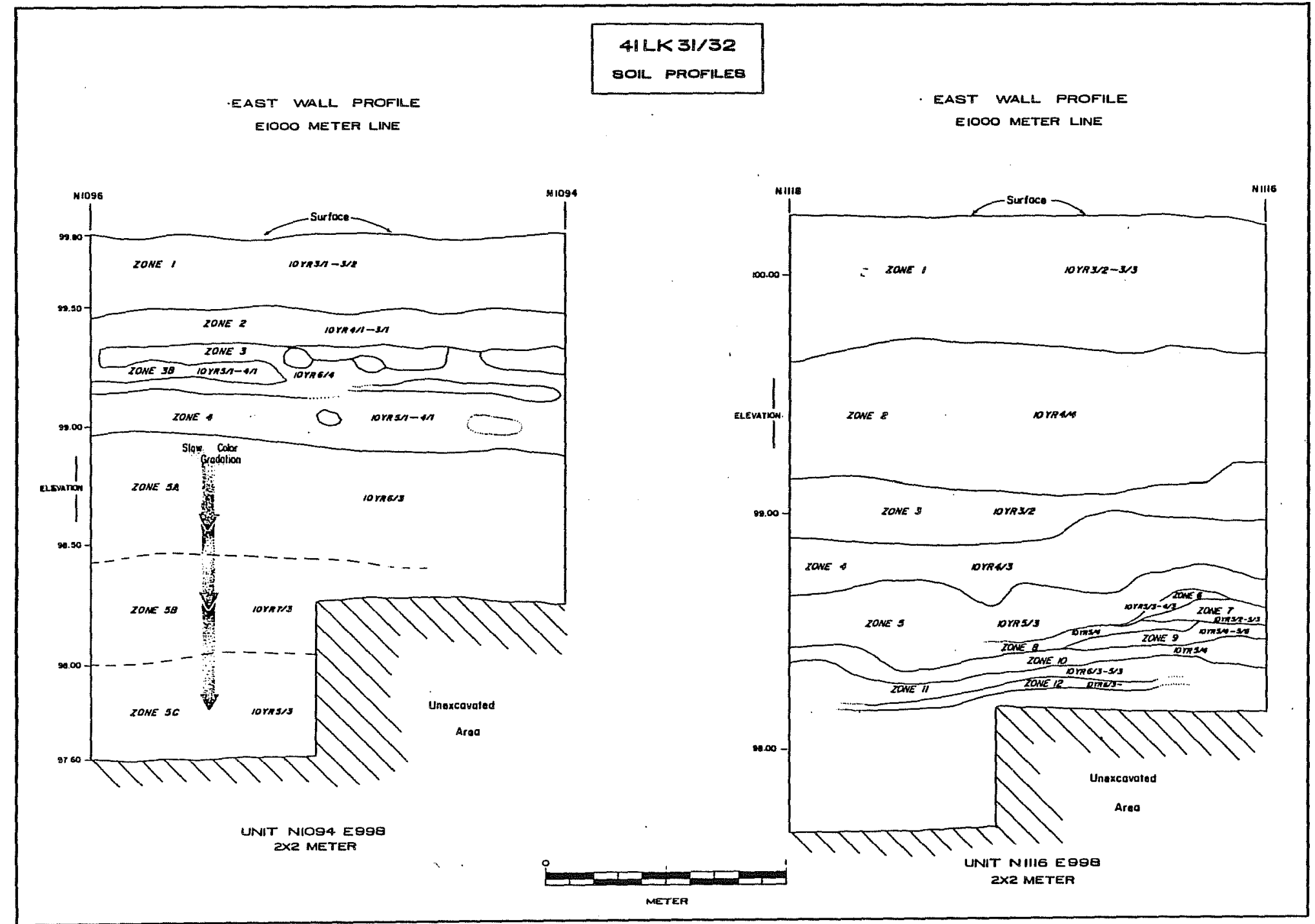

Figure 4. Soil Profiles; East Wall of Units $N 1094$ E998 and N1116 E998 along E1000 Line. 
with another dozen flakes and a biface fragment in level 6 . Feature 12 was uncovered in level 7 (corresponding to soil Zone 3), with a dart point and several chert tools associated with a scatter of burned siltstone rocks. Burned clay, a single chert tool (a retouched flake) and 200 land snails were recovered in level 8 . Density of cultural debris declined in levels 9 through 12 (the final level).

What 1ittle cultural evidence existed in Unit N1094 E998 was noted in two levels occurring between elevations 98.65 and 98.25 or $135 \mathrm{~cm}$ to $175 \mathrm{~cm}$ below surface. Soil in this wide area (Zones $5 \mathrm{~A}$ and $5 \mathrm{~B}$ ) did not correlate in elevation with that of Zone 3 in Unit N1116 E998 (which contained Feature 12) but retained similar features of blockiness in structure. Continuity between the strata represented in the two units could not be established with any certainty.

Unit N1083 E1108

Establishment of this unit (Fig. 3), the easternmost test of $41 \mathrm{LK} 31 / 32$, was necessitated by the cultural debris exposed by the digging of TPC-363 by the Bureau of Reclamation. Initial testing of the site had not extended to this particular area (aside from backhoe trenches and extensive profiling of the geologic pit wal1s) but had determined that deep cultural deposits were present. The unit was established approximately 20 m west of TPC-363.

Despite the depth of Unit N1083 E1108 $(320 \mathrm{~cm})$, complex zonation resembling Unit N1116 E998 and units adjoining TPC-364 was not in evidence (Fig. 5). The profile was quite simple in structure, showing thick soil zones divided by i11-defined areas of contact. Zone 7 was composed of a loosely consolidated light brown sand with traces of clay. This graded upward to Zone 2, darkening to a yellowish brown silty sand. The lower portion of Zone $2 \mathrm{~A}$ is denoted by calcareous mottling and a lack of cultural debris. Zone $2 \mathrm{~B}$ was defined by the presence of snails, mussel shells, and chert apparent in the profile. Again, this grades indistinctly into Zone 3, a dark, grayish brown clay and sand layer. Zone 4 was distinguished by a darker gray hue and a decrease in clay texture. A change to a gray-brown sandy clay marked Zone 5 which graded into a brown sandy loam in Zone 6 . Surface soil in Zone 7 was slightly richer in clay than the preceding zones.

Cultural remains were substantial in several of the excavated levels. From $80-200 \mathrm{~cm}$ below ground surface (levels 4-10), between 10 and 40 chert flakes were recovered per level. Bifaces, cores, and burned sandstone were often associated. Heaviest concentrations of debitage occurred in levels 6,8 , and 9. Leve 6 occupied the lower portion of Zone 3 , whereas levels 8 and 9 occurred at the contact of Zones 3 and $2 B$, respectively. Flake and too 1 density declined dramatically in level 10 (to 115 chert flakes and no tools) and to no cultural recovery in level 11 . Feature 13 was found within level 9 in Zone $2 \mathrm{~B}$.

Correlation with soil zones of other units across the site proved difficult. Diagnostic artifacts were entirely lacking from Unit N1083 E1108, as were the complex, thin, compact zones which characterized Unit N1116 E998 and the units adjacent to geologic test pit TPC-364. Thick zones, slightly differentiated in structure, resembled Unit N1094 E998 in profile but included high proportions 
$41 \mathrm{LK} 31 / 32$

NORTH WALL PROFILE

NIOES METER LINE

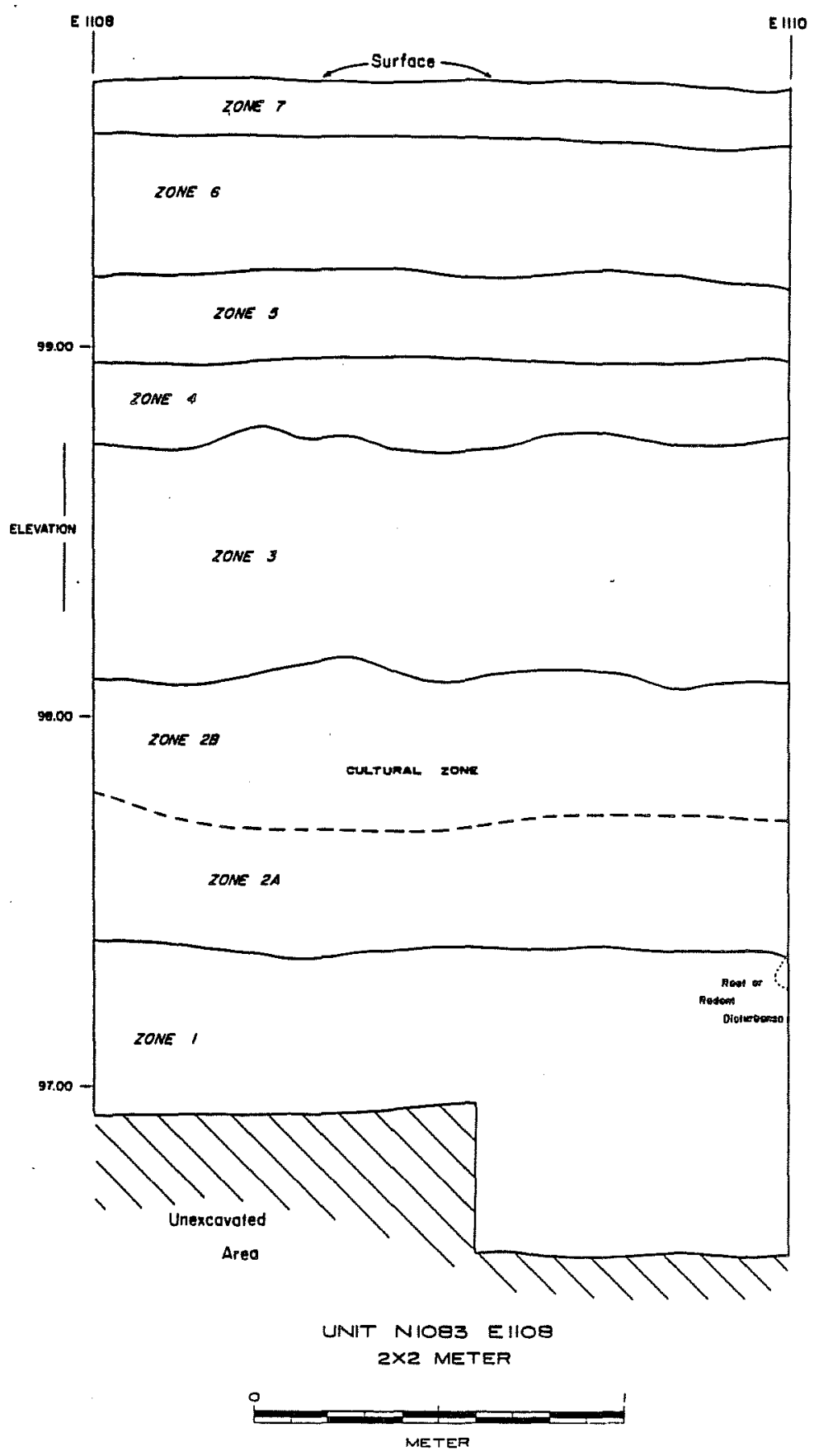

Figure 5. North wall Profile - N1083 E1108. 
of sand in the lower zone, contrasting the clayey, developed structure of the lower zone in Unit N1094 E998. Notation of blocky soil development was in level 5, corresponding to the contact of soil Zones 3 and 4 . This is, interestingly, the final level in which cultural debris was abundant.

TPC-364

The designation for the geologic test pit on the western portion of the site is used to encompass a series of $2-\mathrm{m}^{2}$ excavation units which were established north of and adjoining its edge (Figs. $3 ; 6, a)$. These units were the subject of extensive testing during both phases of investigation, and produced three radiocarbon dates. The testing units included in this series are: N1056 E863 $\left(3 \mathrm{~m}^{2}\right)$, N1055 E863 $\left(1 \mathrm{~m}^{2}\right)$, N1055 E864 $\left(1 \mathrm{~m}^{2}\right)$, N1062 E875 $(3 \times 2 \mathrm{~m})$. Intensive excavation units included are: N1055 E861 $\left(2 \mathrm{~m}^{2}\right)$, N1057 E861 $\left(2 \mathrm{~m}^{2}\right)$, N1059 E861 $\left(2 \mathrm{~m}^{2}\right), \mathrm{N} 1059 \mathrm{E} 863\left(2 \mathrm{~m}^{2}\right), \mathrm{N} 1059 \mathrm{E} 865\left(2 \mathrm{~m}^{2}\right), \mathrm{N} 1057 \mathrm{E} 865(1 \mathrm{x} 2 \mathrm{~m}), \mathrm{N} 1061$ E873 $\left(2 \mathrm{~m}^{2}\right), \mathrm{N} 1063 \mathrm{E873}\left(2 \mathrm{~m}^{2}\right), \operatorname{N1065E873}\left(2 \mathrm{~m}^{2}\right), \operatorname{N1065E875}\left(2 \mathrm{~m}^{2}\right)$.

TPC-364 had yielded the first evidence of deep cultural evidence at 41 LK $31 / 32$ (Fig。7,a,b). Features exposed in the walls of the geologic test pit led to the placement of test units which, in turn, led to the more extensive excavations. Of the 20 cultural features identified during both phases, 18 occurred within the units listed above, as did the three radiocarbon dates.

Extensive profiling undertaken of all excavated units revealed up to 16 soil zones present, beginning with a culturalily sterile soil occurring approximately $250 \mathrm{~cm}$ below ground surface (Fig. 6,e,f). Profiles could generally be divided into an upper meter of thick deposits of silt and sand and a lower meter of thin, discontinuous strata. Zone 2 was the first cultural level in the vertical sequence of deposits, resting atop a light tan sandy clay which was void of cultural evidence. The upper 100-120 cm of deposits appear to represent a dramatic change in deposition from the lower 100-140 cm.

Deposition that resulted in the upper meter of sediment appears to have been the result of a few large overbank floods of substantial sediment load. Deposits were not exposed for enough time to permit pedological processes to "imprint" a new surface before flooding reoccurred. By contrast, deposits occurring below the level of $150 \mathrm{~cm}$ below datum, indicate a series of overbank floods settling as thin layers. Bunker (1982) attributes the stratification to sands, silts, and clays filtering from suspension during falling water levels. Zone 2, thicker and darker than the overlying meter of complex strata, exhibited a well-developed blocky structure, suggesting that it had been exposed to weathering long enough to undergo pedological development.

Soil in the area of TPC-364 was general1y friable in texture and light tan to brown in color. With the exception of Zone 2, blocky gray to brown soils characteristic of the three units on the eastern half of $41 \mathrm{LK} 31 / 32$ did not appear. Zone 2 apparentiy was not contiguous across the site, as units other than those associated with TPC-364 lacked evidence of a deep, wel1-developed, cultura17y rich stratum.

Cultural evidence in the units adjoining TPC-364 (referred to as the scraped area due to the removal of the upper meter of soil prior to extensive excavation) 
Figure 6. General Photos--Prehistoric. a, view west from TPC-363 (4T LK 32) to TPC-364 (41 LK 31). Crew people are working in unit; $b$, overview of Feature 19 in Unit N1063 E873, level 8 (97.97-97.85 elevation). The semicircular collar is an artificial construct marking an area of fired earth left in situ around the rock concentration; $c$, overview of Feature 11 in Unit N1057 E861, level 6 (98.35-98.25 elevation); d, cross section (east to west) of Feature 6 . Note the thin, basin-shaped lense of carbon beneath the rock layer. This feature yielded a radiocarbon date of 2340-2360 B.C. (TX-2922, MASCA corrected). Scale is $30 \mathrm{~cm}$ in length and points upward; e, west wall profile of Units N1055 to N1058 along the E861 line; $f$, north wall profile along N1061 line from E861 (left) to E865 (right). 

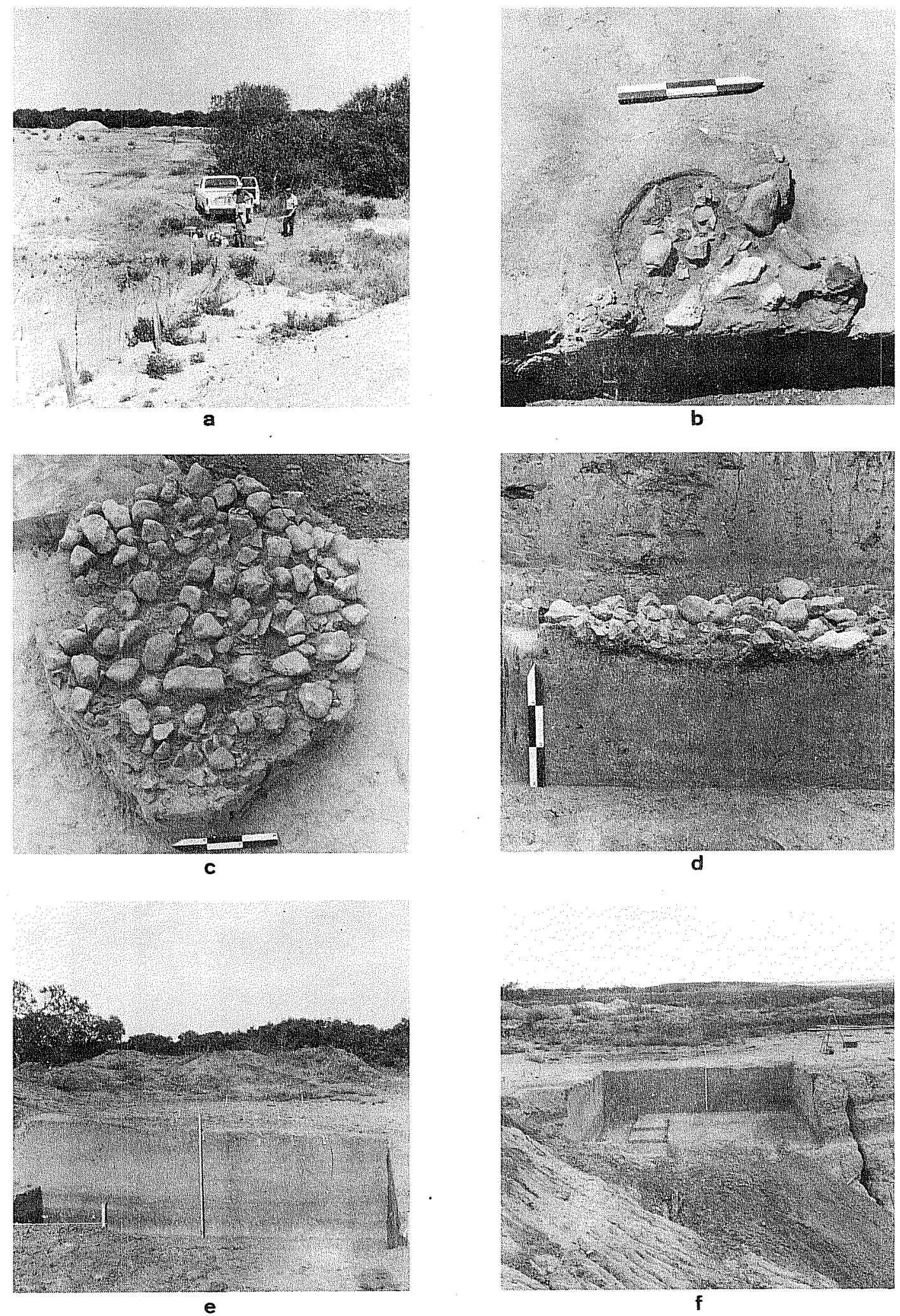
Figure 7. General Photos--Prehistoric. a, view east from TPC364 (41 LK 31) to TPC-363 (41 LK 32), marked by backdirt piles. The line of trees along the horizon follows the Frio River channel. The area in the left foreground was cleared of brush shortly before 41 LK $31 / 32$ was tested in January 1978. To the right is pasture land; $b$, view north acrosS TPC-364 to the test units excavated during initial assessment of the site. Unit N1056 E863 is to the left (west). Unit N1062 E875 is to the right. The backdirt pile behind the units came out of the geologic test pit. The channel of the Frio River is marked by the 7 ine of trees in the background. The earliest cultural remains found on the site occur in the dark soil layer seen roughly $1 \mathrm{~m}$ below the unit floors; c, view north of Features 2 and 3 (on floor) and Feature 6 (shown in cross section on pedestal). Note the zonation of soil deposits in the unit's north wal1; d, detail of mussel she 17 concentration in Feature 20, Unit N1065 E875, leve1 9 (97.85-97.75 elevation); e, overview of Feature 10 in Unit N1062 E875; f, west and north (partial) wall profiles of Unit N1062 E875. A cross section of Feature 10 is visible on the floor of the unit. 


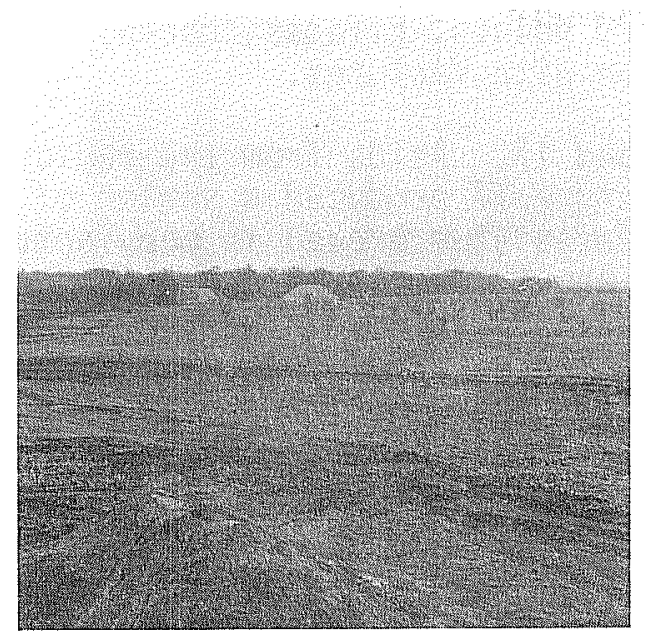

$a$

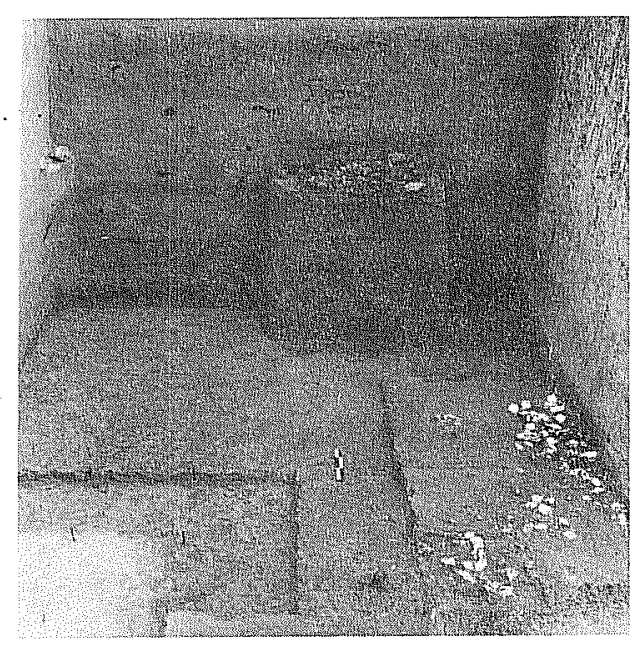

6

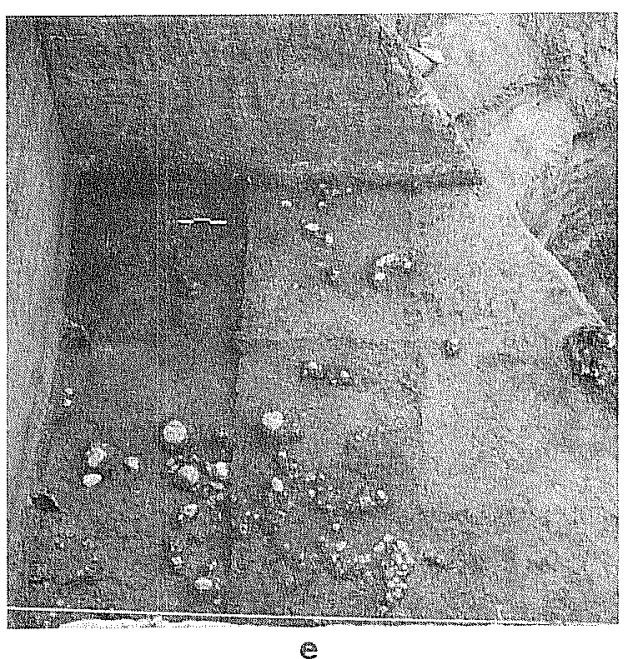

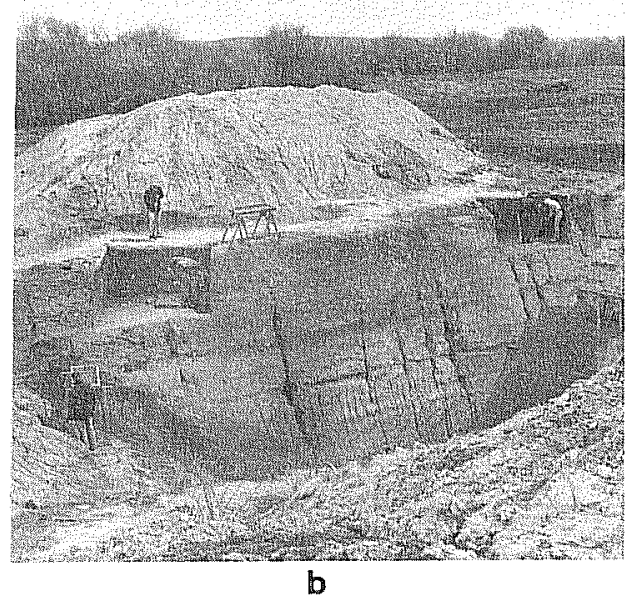
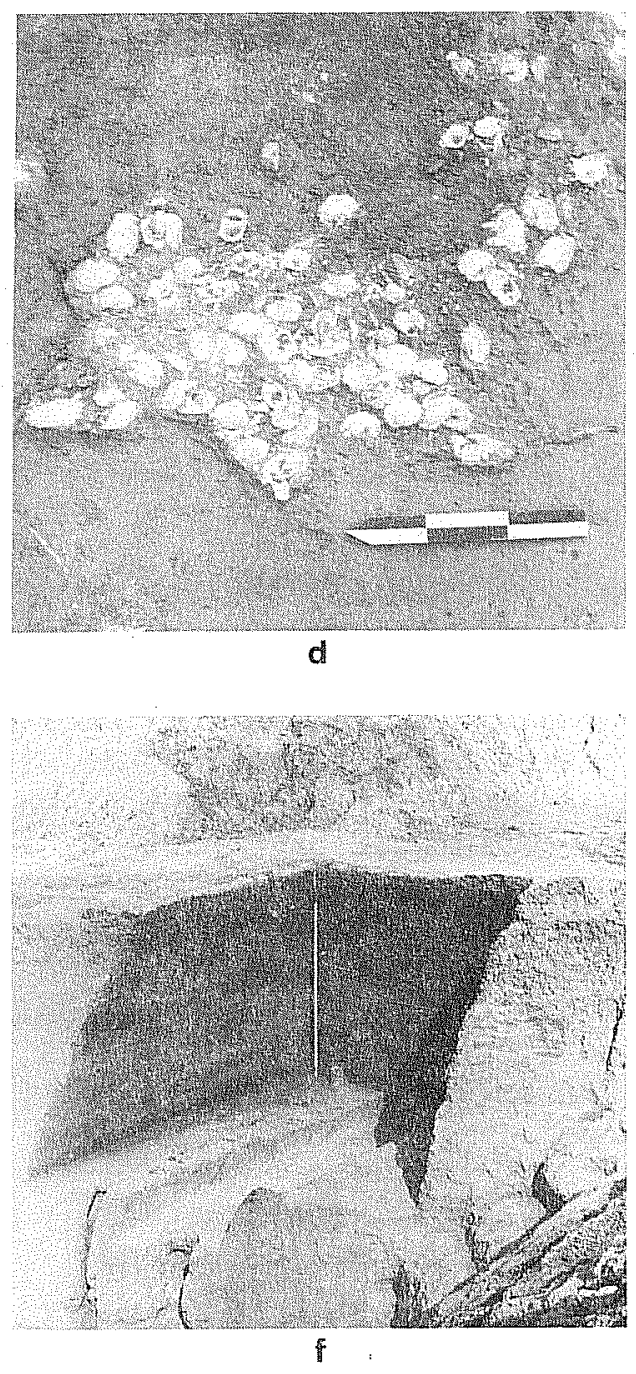
was thinly spaced, occurring as features, concentrations of mussels or snails, and chert flake scatters. Chert tools--dart points, bifaces, cores, etc.,-were rare and tended to occur in association with features.

Zone 2 contained Features 1,2, 3, 5, 10, and 17. Aside from the radiocarbon dates extracted from Features 2 and 10, Feature 17 produced a series of tools which included three concave-based thin bifaces (two broken in manufacture), one thick biface, two utilized flakes, and about 200 flakes and chips of lithic debitage. Feature 2 contained a fish otolith amid a compact lense of mussel shells and snails, but only a single flake. Feature 3, located $1 \mathrm{~m}$ west of Feature 2, contained four chert flakes and very few snails or mussel shel1s. In general, Zone 2 cultural debris was associated with features and not scattered throughout the zone (Figs. $7, \mathrm{C} ; 8$ ).

Soil Zones 3 and 4 (depth approximately 235-255 cm below datum) were grouped into a single cultural stratum. Included with this were Features 9, 14, 15, and 20 , and the only two typologically definable dart points recovered in the extensive excavations. A Travis point (Suhm and Jelks 1962:251-252) was recovered at elevation 97.70 but was not associated with any other cultural evidence. In Feature 14, a Lange point (tentatively identified from Suhm and Jelks 1962:203-204) was recovered in association with a circular soil stain, several siltstones, and several dozen mussel shells. Feature 9 appeared as a charcoal stain with no directly associated cultural debris. A charcoal sample extracted from the feature for purposes of wood identification proved inadequate (Phil Dering, personal communication). Features 15 and 20 were noncompact scatters of burned siltstone. Mussel shells were associated with Feature 20 (Fig. 7,d), but neither contained evidence of lithic tools or flaking debris. Isolated artifacts, recovered in no definite association with features, included two cores, a biface fragment, a unifacial tool, and a ground stone fragment.

Cultural evidence appeared to group again at an elevation of 195-225 cm below datum. Features 8,18 , and 19 occupy this somewhat thick series of soils (identified as $5,5 \mathrm{~A}$, and $5 \mathrm{~B}$ or 4,5 , and 6 depending on location in the vertical profile), as well as numerous isolated artifacts. Feature 19, a small basin-shaped hearth, containing fire-fractured chert and siltstone cobbles was associated with a concentration of Rabdotus snails and a scatter of chert flakes. Feature 18, $2 \mathrm{~m}$ south of Feature 19, contained only scattered burned rocks. More complex in makeup was Feature 8 which covered almost $2 \mathrm{~m}^{2}$ when fully exposed. A large charcoal (?) stain was surrounded by several flint flakes and a core fragment. Burned earth was evident near the center of the scatter. Artifacts which occurred within the cultural zone included two gouges, a ground stone fragment, two cores, a biface fragment, one edge worn flake, and a concentration of approximately 150-200 chert flakes in level 7 of Unit N7065 E873.

Features 6 and 11, morphologically identical in size, construction, and content, centered at $182 \mathrm{~cm}$ and $175 \mathrm{~cm}$ depth, respectively. Each was ambiguously assigned to soil Zone 7. Cultural evidence at these elevations was virtually nonexistent, including only a single edge worn flake in the tool category. Flaking debris was likewise scant, and neither feature had associated tools or lithic debitage. 


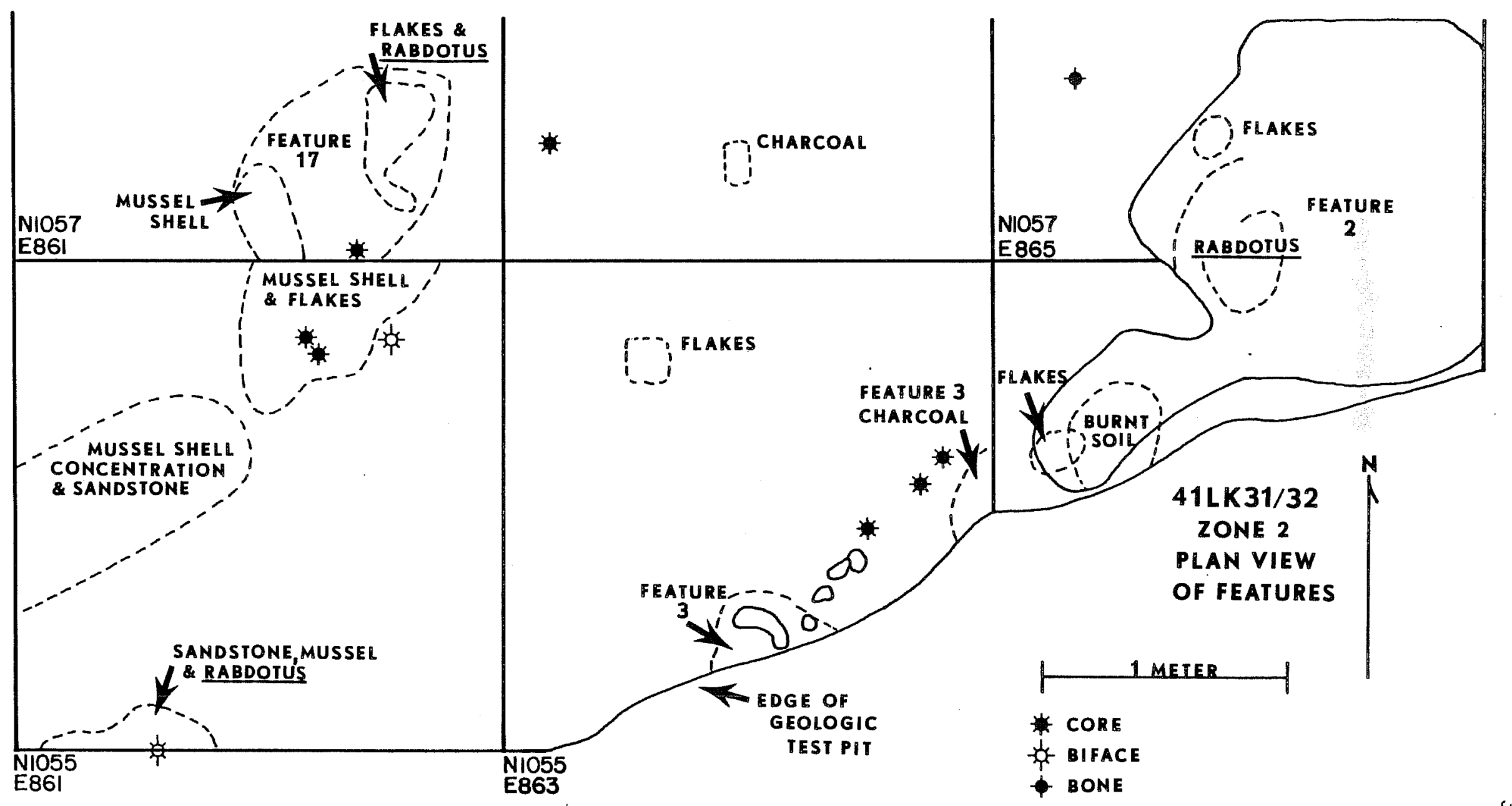

Figure 8. Plan View of Zone 2 Features. Southern half of Feature 17 is $5 \mathrm{~cm}$ higher than the northern portion. $\omega$ 
The final cultural zone identified occurred between 140-155 cm depth. Corresponding soil zones at this depth were Zones 10 and 11 as defined in vertical profiles exposed during the extensive excavation phase. Features 7 and 16 occurred within this cultural zone, as did isolated artifacts. Of the two, Feature 7 was a small soil stain associated only with scattered burned rocks. Feature 16, however, exhibited an excellent sequence of chert cobble reduction and testing, retaining the original cores, a hammerstone, and over 125 flakes and chips detached from them. A large concentration of mussel shells was also associated with Feature 16. Isolated artifacts recovered included two biface fragments, several core fragments, and an edge worn flake. In Unit N1059 E861 (level 2) a concentration of 90 burned chert flakes was recovered.

The test excavations had defined a fifth cultural horizon $50 \mathrm{~cm}$ below the contemporary ground surface. It produced no features or diagnostic artifacts and was removed with the meter of overburden prior to extensive excavations.

Profiles in the scraped area (adjoining TPC-364) generally were structured in the following manner: a culturally sterile basal stratum of clayey silt was overlain by a well-developed soil zone rich in cultural evidence. Radiocarbon dates from this zone (Zone 2) indicate that human occupation had occurred by 4710 B.P. The next 1-1.2 m of deposits of horizontal deposits was marked by numerous thin strata and discontinuous soil zones, generally composed of very fine silty sands. The remaining meter of deposits deposited after 3970 B.P. (Feature 6, elevation $180 \mathrm{~cm}$ below datum, TX-2922) were thicker, representing only three to four soil zones up to the modern surface.

The basic pattern of sediments was studied by Bunker (1982) in relation to the terraces he defined. Basically, four terraces were recognized by Bunker, corresponding to those identified by Lynn, Fox, and O'Ma1ley (1977) as "Modern Floodplain," "Floodplain," "Fossil Floodplain," and "Pleistocene Terrace." These are described by Bunker (1982) as being generalized and ranging in age from youngest to oldest, numbered 1 through 4 respectively. Other terraces were present but described as "isolated, discontinuous, and of .. . sma11 areal extent ..." and were not considered in the study.

\section{Summary}

Human occupation at site 41 LK $31 / 32$ was first established during development of the phase 3 terrace building. Bunker (ibid.) characterized this as a period of river aggradation and floodplain construction as the Frio River became established as a fine-grained meander belt system. Phase 2 of the floodplain building began sometime after 2000 B.P. as noted in sediments from 41 MC 29. Occupation of the Frio River floodplain may have preceded 4710 B.P., but as Bunker (1982) notes, this evidence would have been destroyed by scour of the yet-established phase 3 floodplain. Early stages of phase 3 were marked by a course bedload braided stream and migrating channel which would have tended to destroy cultural evidence. Zone 1 is considered indicative of early phase 3 stabilization, whereas Zone 2 with the radiocarbon date of 4710 B.P. is considered to be evidence of phase 3 river stabilization. Phase 2 soils are felt to be represented in the upper meter of soils at $41 \mathrm{LK} 31 / 32$ 
indicating less frequent flooding with greater amounts of sediments being deposited in each flood.

Baker and Penteado-Orellana (1977) attempted to make statements about climatic influences affecting the Colorado and San Gabriel Rivers in central Texas. Bunker (1982) correlated terrace phases with those found by Baker and PenteadoOrellana, assuming that broad climatic controls influencing the Colorado and San Gabriel Rivers also influence the deposition sequences of the Frio River. Phase 3 of the Frio River is correlated with Phase 5 of deposition along the San Gabriel and Colorado Rivers, based on a change from a braided to a meandering stream. Bunker (ibid.) states that:

Sometime before 4710 years B.P. the phase 3 Frio River was aggrading its channel and constructing a floodplain by lateral point bar growth and vertical overbank sedimentatation. The aggradation was probably in response to a mesic interval. Increased precipitation and the resultant improvement in vegetal cover on side slopes resulted in finergrained weathering products being supplied to the Frio River as sediment. The consequent change in sediment load from coarse sediment to fine sediment, together with more uniform base flow and reduced flood discharge, caused the Frio River to develop a floodplain occupied by a relatively stable, meandering channel.

Phase 3 is tentatively dated by Bunker (1982) to have lasted from 4710-2000 years ago. During this time the Frio ". . . straightened, narrowed, and downcut . . " in what could be a response by the river to more xeric climatic conditions.

Finally, Bunker (ibid.) suggests that the 41 LK $31 / 32$ profiles suggest climatic episodes that can be correlated with sites such as Arenosa Shelter on the Devil's River and Loeve-Fox on the San Gabriel River. Sediments in these sites suggest that at least the same broad climatic episodes affected all three rivers from 3000-2000 years ago. Earlier relationships in sedimentation were not necessarily well correlated, as the phase 5 of the Colorado and San Gabriel Rivers is absent in the Frio River terrace (Bunker 1982).

\section{RADIOCARBON ANALYSIS}

Despite the collection of what, at the time, appeared to be significant amounts of charcoal, the extensive excavations produced no radiocarbon assays. This was a particular disappointment in view of the illuminating dates obtained as a result of the initial test excavations. It was hoped that this original suite of assays could be confirmed and expanded through additional dates. Unfortunately, the samples recovered through our work were not large enough to result in reliable assays.

Before submission to the Radiocarbon Laboratory, The University of Texas at Austin, charcoal samples underwent basic processing to remove impurities and facilitate dating. Samples were hand picked of larger organic fragments then 
subjected to flotation in regular tap water. When all of the charcoal had been separated from the other sediments, it was dried under strong 1 ight and then repackaged.

Feature 11, in particular, yielded several foil pouches of charcoal. However, upon cleaning and drying the sample, less than the desired 4 gm was actually obtained. Considering the proximity of Feature 11 and Feature 6 (dated earlier), this was not crucial. Feature 14, occurring stratigraphically between Zone 2 and Feature 11, was felt to be a crucial element in the occupation sequence. It was therefore a considerable disappointment when barely $2 \mathrm{gm}$ of charcoal could be cleaned from the collected fill. Samples from Features 15 and 19 were additionally floated and picked but produced so little that a date could not be obtained.

Isolated pieces of charcoal occurred occasionally in the western block of excavation units. Their lack of association with features or occupation negated their effectiveness in site interpretation. However, charcoal occurring in this manner was submitted to the Texas A\&M Paleobotany Laboratory for plant species identification. Table 2 presents a summary of the radiocarbon dates obtained.

\section{TABLE 2. SUMMARY OF RADIOCARBON DATES*}

\begin{tabular}{|c|c|c|c|c|c|}
\hline Feature & Elevationt & $\underline{T X \# \nabla}$ & B.P. $\theta$ & A.D./B.C. & MASCA Corrected $\pi$ \\
\hline $\begin{array}{l}1 \\
3 \\
6\end{array}$ & $\begin{array}{l}97.54-97.50 \\
97.20 \\
98.33-98.10\end{array}$ & $\begin{array}{l}2920 \\
2921 \\
2922\end{array}$ & $\begin{array}{l}4710 \pm 80 \\
4690 \pm 80 \\
3970 \pm 160\end{array}$ & $\begin{array}{l}2760 \text { B.C. } \\
2740 \text { B.C. } \\
2020 \text { B.C. }\end{array}$ & $\begin{array}{ll}3380 & \text { B.C. } \\
3350-70 & \text { B.C. } \\
2340-60 & \text { B.C. }\end{array}$ \\
\hline
\end{tabular}

*All samples dated were collected during test excavations. Samples collected from Features 11 and 20 in Phase II a 11 proved to be inadequate for radiocarbon assay.

+A11 depths relative to arbitrary datum of 100.0 meters.

VTX: University of Texas at Austin Laboratory Number.

ӨB.P.: before present (i.e., before 1950).

$\pi$ Ralph, Michael, and Han 1973.

\section{FEATURES}

The cultural information derived from 41 LK $31 / 32$ was contained primarily in 20 features excavated during both stages of investigation (Fig.9). The testing phase recorded 10 features (defined herein as discrete activity areas composed of cultural debris) as did the extensive excavations. In the absence of abundant stone tool remains, features and stratigraphic information were the main interpretive tools in determining site function.

Features were mapped in detail when encountered in the field. Plan views and cross sections were drawn for each, and photographs were taken. After plotting artifacts and associated cultural debris, feature fill was passed through 1/4inch hardware mesh and 1/16-inch window screen with water. Charcoal samples 


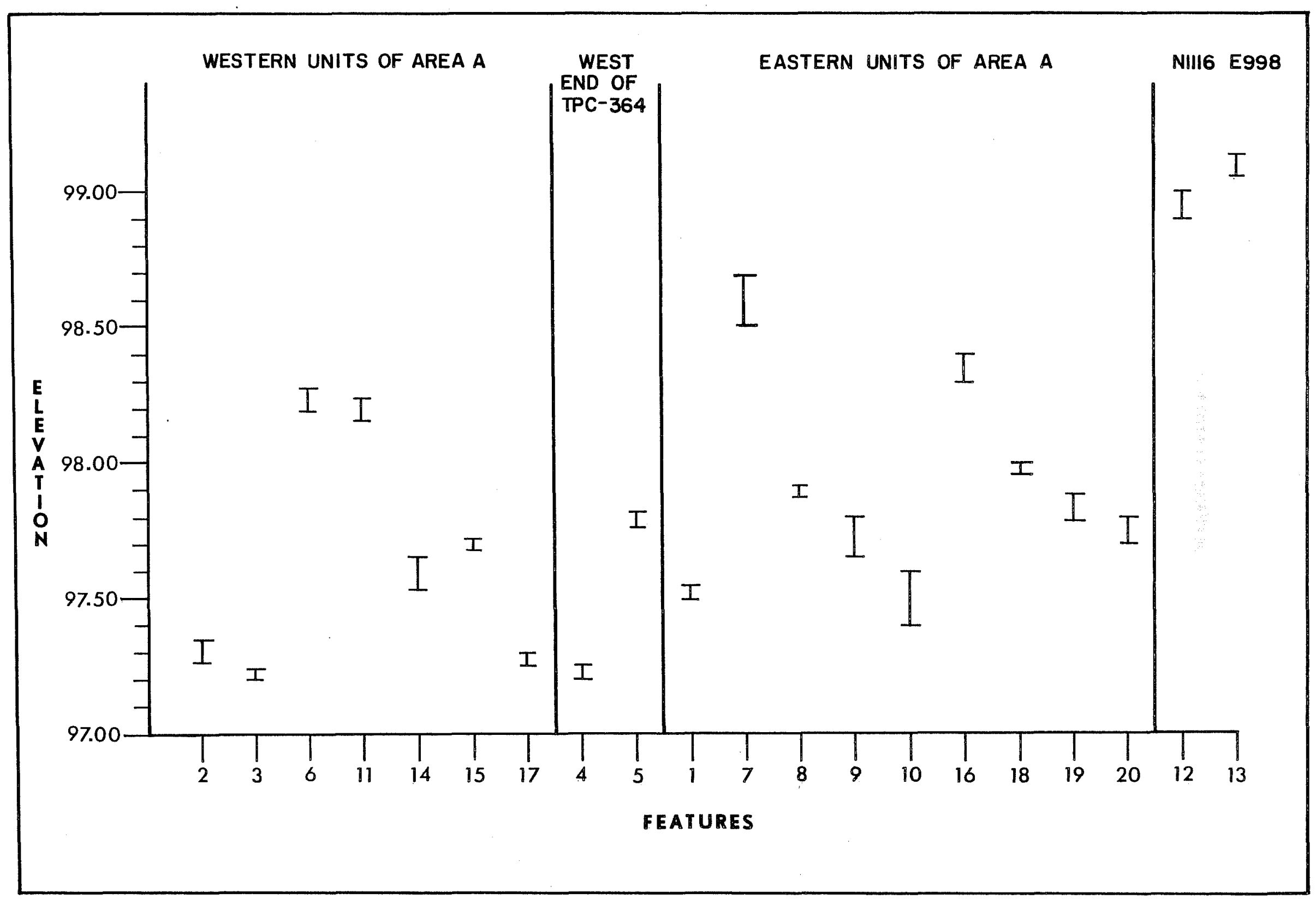

Figure 9. $41 \mathrm{LK} \mathrm{31/32} \mathrm{Feature} \mathrm{Thickness} \mathrm{and} \mathrm{Relative} \mathrm{Stratigraphic} \mathrm{Position.}$ 
were collected from every feature exhibiting charcoal flecks or stains, but only three features were eventually radiocarbon dated (see Table 2). Feature 1 was dated at $4710 \pm 80$ B.P., Feature 3 was dated at $4690 \pm 80$ B.P., and Feature 6 was dated at $3970 \pm 160$ B.P. A11 dates were derived from the earlier test excavations.

Feature Descriptions

Feature 1

Unit: N1062 E875

Depth: 97.54 to $97.50 \mathrm{~cm}$

Stratigraphic Location: Zone 2

Size and Thickness: $65 \times 35 \times 4 \mathrm{~cm}$

Description: This feature was constructed of chert and sandstone cobbles partially destroyed during the Bureau's excavation of TPC-364. The remaining oval area was tightly compact with some flecks of charcoal overlying the rocks. Beneath the burned rocks, a shallow, slightly basin-shaped depression is visible. This consists of a thin layer of sand overlying a thin layer of charcoal. A radiocarbon date of 2760 B.C. was obtained. No artifacts or cultural debris were directly associated with the feature (Feature 10 was located $2 \mathrm{~m}$ northwest of Feature 1).

Feature 2

Units: N1056 E865/N1057 E865

Depth: 97.46 to $97.25 \mathrm{~cm}$ (center point)

Stratigraphic Location: Zone 2

Size and Thickness: $190 \times 155 \times 15 \mathrm{~cm}$

Description: Feature 2 appeared as a conglomerate of Rabdotus shells, mussel shells, thermal chert spalls, and scattered sandstone. Several hundred musse] shells, mostly of uniform size and hinged-downward, were interspersed with the Rabdotus. Additionally, corroded bone (Trionyx was identified) and two drum otoliths were recovered from the mixed fill. No evidence of a depression or pit preparation was discernible, although charcoal flecks and small chunks of burned earth occurred sporadically throughout the she11 debris.

One utilized flake was associated with the concentration, occurring within the clustered shells. Feature 3, a small sandstone hearth (?), was mapped $2 \mathrm{~m}$ southwest of Feature 2.

Feature 3

Units: N1055 E863/N1055 E864

Depth: $97.20 \mathrm{~cm}$

Stratigraphic Location: Zone 2

Size and Thickness: $50 \times 70 \times 10 \mathrm{~cm}$

Description: The construction of Feature 3 strongly suggests a hearth function. Six sandstone cobbles outlined a basin-shaped crescent of charcoal 
underlain by burned soil. Fragments of mussel she11, chert flakes (including a biface thinning flake and biface distal tip), and several types of land snail fragments occurred within the fill. Burned and unburned mussel she 11 fragments were also noted. A sufficient quantity of datable charcoal was collected and radiocarbon dated at 2740 B.C.

Unfortunately, an unknown portion of Feature 3 was removed by the Bureau's TPC-364 and by subsequent erosion. Enough remained, however, to stratigraphically link this feature with Feature 2.

\section{Feature 4}

Unit: Western side of TPC-364

Depth: $97.24 \mathrm{~cm}$

Stratigraphic Location: Zone 2

Size and Thickness: $30 \times 35 \times 30 \mathrm{~cm}$

Description: Primarily, Feature 4 was a small oval concentration of highly fragmented mussel shelis lacking any further association other than four small chunks of possibly burned sandstone. No charcoal flecks, burned soil, or pit preparation was discernible. The location of the feature deep in the western profile of TPC-364 permitted only basic vertical exposure prior to its destruction by erosion.

\section{Feature 5}

Unit: Western Side of TPC-364

Depth: $97.79 \mathrm{~cm}$

Stratigraphic Location: Upper Portion of Zone 4

Size and Thickness: $10 \times 10 \times 2 \mathrm{~cm}$

Description: Although more complex in the number of components than Feature 4, Feature 5 was smaller and less compact in construction. A single sandstone fragment was recorded along with about one dozen land snails (Rabdotus) and four fragmented mussel shel1s. No charcoal was noted although a single fragment of thermally spalled chert was recovered.

Again, the precarious location of the concentration made vertical exposure difficult and destruction by erosion rapid.

Feature 6

Units: N105 E864/N1058 E865

Depth: $98.33-98.10 \mathrm{~cm}$

Stratigraphic Location: Zone 5

Size and Thickness: $110 \times 87 \times 23 \mathrm{~cm}$

Description: Feature 6 was a large, tightly compacted circular concentration of thermaliy fractured chert cobbles. A slight basin was discernible in cross section, as the rocks rested on a thin layer of charcoal which, in turn, rested on a discontinuous layer of burned soil. Numerous chert spalls occurred in the feature fil1. Enough charcoal was present that three samples for a radiocarbon assay were gathered resulting in a radiocarbon date of 2020 B.C. 
(Fig. 6,d). In size, the feature was roughly $1 \mathrm{~m}$ in diameter and more than $20 \mathrm{~cm}$ thick from the base of the burned soil to the top of the burned rock. Only four fragments of sandstone were noted among the chert.

A mussel shell concentration was found southwest of the feature, and one burned mussel fragment was found in the feature fi11. Feature 11 was mapped $2 \mathrm{~m}$ west of Feature 6 in the same zone. Scarce lithic debris and no diagnostic tools could be directly associated with Feature 6 . Fragments of land snails, mussels, and thermal chert spalls were scattered around the outer edge of the hearth.

Feature 7

Units: $\mathrm{N} 1062 \mathrm{E875}\left(2 \mathrm{~m}^{2}\right) / \mathrm{N} 1063 \mathrm{E876}\left(1 \mathrm{~m}^{2}\right)$

Depth: $98.75-98.60 \mathrm{~cm}$

Stratigraphic Location: Contact of Zones 10 and 11

Size and Thickness: $56 \times 56 \times 15 \mathrm{~cm}$

Description: Despite unintentional damage inflicted during excavation, enough remained of Feature 7 to provide an accurate account of the cultural remains. Very little burned rock occurred with the feature, al though traces of charcoal and burned soil were noted. The burned rocks were apparently not compact, instead being loosely arranged. No associations were recorded in or around the small circular burned area.

Feature 8

Units: $N 1062$ E876 $\left(2 \mathrm{~m}^{2}\right) / \mathrm{N} 1063 \mathrm{E} 877\left(1 \mathrm{~m}^{2}\right)$

Depth: $97.91-97.87 \mathrm{~cm}$

Stratigraphic Location: Zone 4

Size and Thickness: $64 \times 75 \times 4 \mathrm{~cm}$

Description: This feature was defined by the presence of a large, oval area of burned earth surrounded by an irregular scatter of several types of cultural debris. Hardened discolored earth with evidence of charcoal and ash mottling covered an area $25-30 \mathrm{~cm}$ in diameter, whereas cultural debris and 1 ighter staining spread more than $1 \mathrm{~m}$ in all directions. Lithic debitage, including flakes, one core fragment, and a large chunk, were recorded. Mussel and snail shells were abundant, particularly in the area southeast of the burned earth area. A dark brown stain of undetermined origin enclosed a semicircular area to the north of the burned earth. No stones of any sort appear to have been used in construction.

Feature 9

Units: N1062 E875 $\left(2 \mathrm{~m}^{2}\right) / \mathrm{N} 1062$ E876

Depth: $97.80-97.67 \mathrm{~cm}$

Stratigraphic Location: Zone 3

Size and Thickness: $75 \times 60 \times 13 \mathrm{~cm}$

Description: Directly below Feature 8 and inconclusively associated with it lay Feature 9 . The actual depth below Feature 8 ranged between a $7-\mathrm{cm}$ overlap and a $10-\mathrm{cm}$ separation. Again, excavation damage to both obscured potential relationships or differences which might have been present. 
A complete absence of burned rocks characterized this feature. An irregular circular stain was marked with charcoal chunks and fragments of broken mussels. In cross section, charcoal staining had leached into the soil, although no indication of a basin outline was clearly evident. Staining actually reached deep enough to suggest an intrusion into Zone 2, although evidence for such a pit was also lacking. Two charcoal samples were extracted from the feature fill.

Feature 10

Units: N1062 E875 (NW, NE Quads)/N1064 E875 (SW, SE Quads)

Depth: $97.67-97.39 \mathrm{~cm}$

Stratigraphic Location: Zone 2

Size and Thickness: $3 \times 2.4 \times 22 \mathrm{~cm}$

Description: The feature covered a broad horizontal area of about $4 \mathrm{~m}^{2}$ in Zone 2. Burned chert nodules and sandstone were scattered across a large portion of discolored soil (Fig. 7,e,f). Ash, charcoal, and burned earth all contributed to the discoloration. Fragments of burned bone and snail were also recorded. A pile of compact burned rocks in a deeply stained northeast portion of the feature may be indicative of pit construction. Feature 1 is located less than $2 \mathrm{~m}$ southeast of Feature 10 and is possibly related to the same occupational episode. Soil matrix and charcoal samples were taken after a cross section was completed (Fig. 10).

Feature 11

Units: N1057 E961 (NE Quad)/N1059 E861 (SE Quad)

Depth: $98.25-98.05$ (from cross section)

Stratigraphic Location: Zone 5 (as defined TTU 102)

Size and Thickness: $115 \times 101 \times 20 \mathrm{~cm}$

Description: A7though quite similar to Feature 6, Feature 11 differed in its lack of any sandstone and in its bas in shape (Fig. 6,C; 11). Closely packed chert cobbles were aligned side by side (as opposed to stacked) in a rough circular outline. Al1 of the cobbles were thermally spalled and surrounded by charcoal, although most of the charcoal was in the form of a fine powder mixed with the fire-hardened soil beneath the feature. No artifacts were found within the two $1-\mathrm{m}^{2}$ units where the feature occurred. More than 100 Rabdotus snails were uncovered to the northwest of the feature within the same $10 \mathrm{~cm}$ of Zone 5. Some petrified wood was included within the feature, although chert cobbles were the preferred thermal conductors.

Feature 6 was associated with Feature 11. No tools or debitage were found in any association.

Feature 12

Unit: N1116 Eg98 (NE Quad, $1 \mathrm{~m}^{2}$ )

Depth: $98.97-98.85 \mathrm{~cm}$

Stratigraphic Location: Level $7(99.10-98.90 \mathrm{~cm})$; Zone 9

Size and Thickness: $60 \times 75 \times 10 \mathrm{~cm}$ 

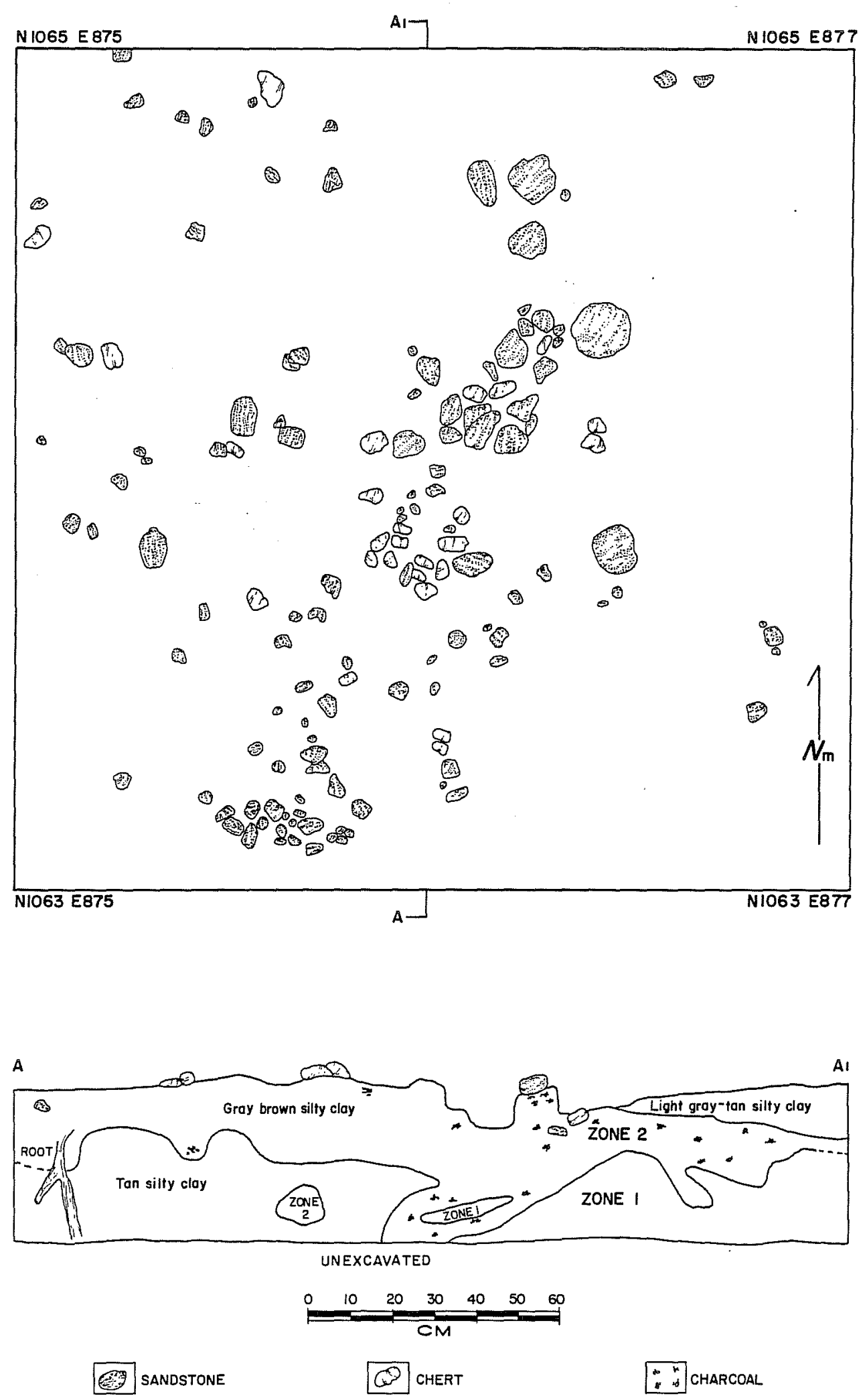

$41 L K 31 / 32$

FEATURE 10

PLAN VIEW AND CROSS SECTION

Figure 10. Plan View and Cross Section of Feature 10. 

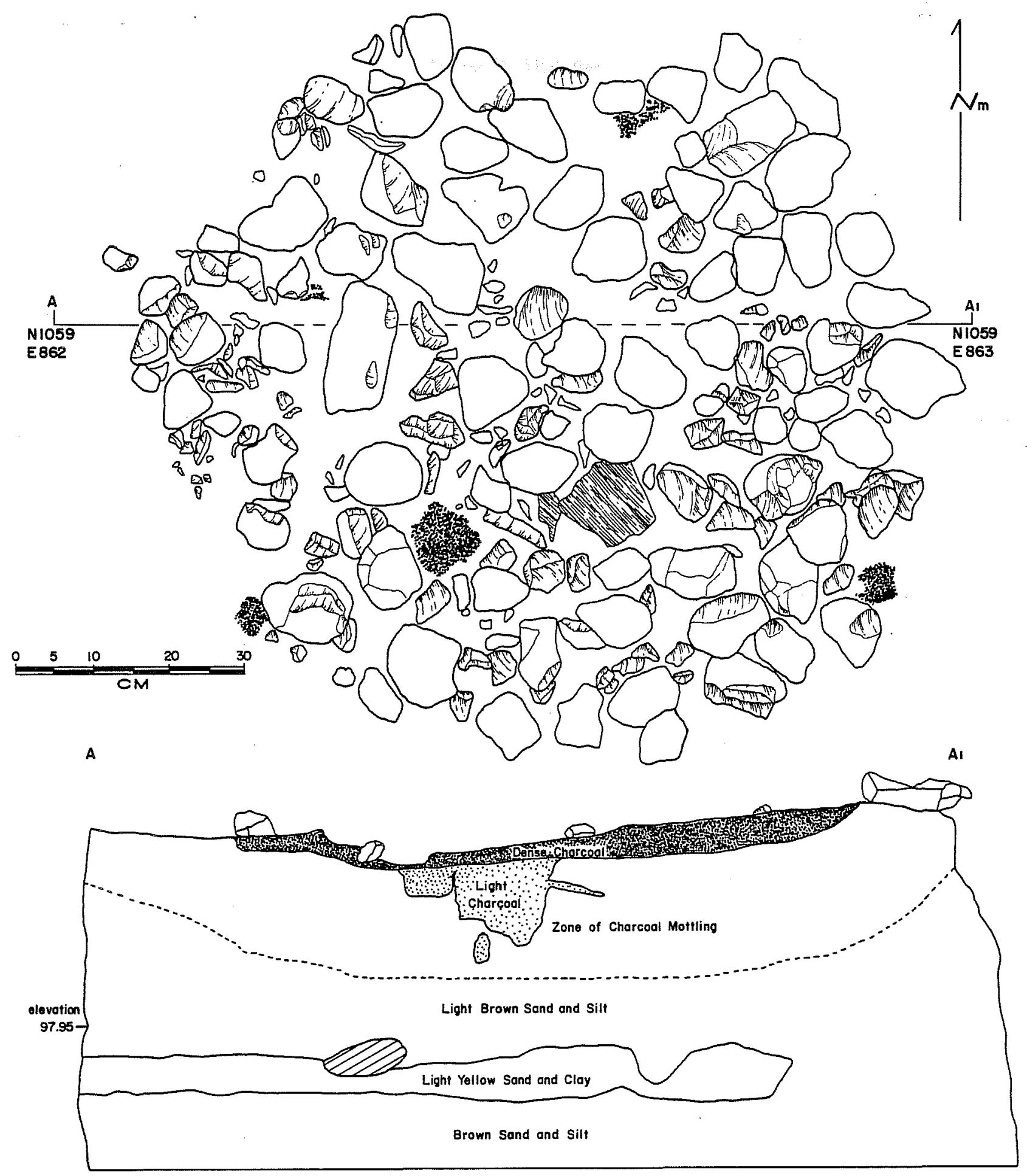

CHARCOAL

D] CHERT

CHERT with FRACTURES

PMTH PETRIFIED WOOD

RABDOTUS SNAIL

SOIL DISTURBANCE/RODENT BURROW

$41 L K 31 / 32$

FEATURE I।

PLAN VIEW AND CROSS SECTION

Figure 11. Plan View and Cross Section of Feature 11. 
Description: Approximately two dozen various stones (sandstone, tuffaceous sandstone, chert, and petrified wood) were arranged in a loose scatter containing a dart point (Abasolo ?), core, biface fragment, and several flakes. Some burned rock was found in the southeast quadrant of the level in questionable association with the feature. None of the rocks in the northeast quadrant appeared to have been burned. Charcoal flecks were present in the level.

The dart point (?) was chipped from fine siliceous wood, whereas the core and distal biface fragment were of locally obtainable chert.

Feature 13

Unit: N1083 E1108 (SE, SW Quads)

Depth: $98.14-98.06 \mathrm{~cm}$

Stratigraphic Location: Level $9(98.15-97.95 \mathrm{~cm})$; Zone 5

Size and Thickness: $35 \times 38 \times 8 \mathrm{~cm}$

Description: Although sma11, Feature 13 encompassed most of the cultural debris found in the site. Chert cobbles, sandstone, siltstone, and petrified wood were present in a loosely packed oval, with some indication of burned soil surrounding it. Snail she11, mussel shell (some burned), and a few chert flakes occurred within and around the feature. Large quantities of mussel shells and Rabdotus snails occurred thoughout level 9 as well. Charcoal flecks were present, although once again not in a collectible quantity.

Feature 14

Units: N1057 E861/N1056 E861 (NW Quad)/N1056 E862 (NE Quad)

Depth: $97.67-97.55 \mathrm{~cm}(?)$

Stratigraphic Location: Contact of Zones 3 and 4

Size and Thickness: $95 \times 140 \times 12 \mathrm{~cm}$

Description: Several different components comprise Feature 14. A central stain, apparently composed of ash, charcoal flecks, and clay, is surrounded by a semicircle of burned soil. Two siltstone rocks occupied the area of the stain. The stain was a narrow basin in cross section, slightly more than $12 \mathrm{~cm}$ deep. Within a meter of the stain, a large concentration of mussel shel1 (Unio and Lampsilis) lay to the south. Debris extending into N1056 E862 contained numerous mussel shell fragments and Rabdotus. Some burned chert cobbles (including thermal spalls) and a siltstone fragment displayed grooves suggestive of an abrasive action. A dart point (Lange) was found $0.5 \mathrm{~m}$ southeast of the central stain. Feature 15 resembles and is possibly an extension of Feature 14. A charcoal sample collected from the area of the stain was of insufficient size to yield a radiocarbon date.

Feature 15

Unit: N1059 E86T (SE Quad)

Depth: $97.69 \mathrm{~cm}$

Stratigraphic Location: Between Zones $2 \mathrm{~B}$ and 3

Size and Thickness: $79 \times 62 \times 5 \mathrm{~cm}$ 
Description: Siltstones (burned?), approximately fist-sized, were scattered across a thin layer of mussel she17s. Some patches of burned soil and flecks of charcoal were scattered among the mussel shells. Besides a single chert flake intermixed in the shells, there were no immediate associations. The mussel shell occurred in two rough concentrations to the southeast and northwest of the siltstone scatter, although shells were strewn throughout as well. Again, no evidence of a basin shape or any preparatory work in forming the hearth was present. Burned earth was noted within the area of the siitstones, but extended only to a depth of $2 \mathrm{~cm}$ at the maximum.

Feature 16

Units: $\quad$ 1061 E873/N1063 E873

Depth: $98.35 \mathrm{~cm}$

Stratigraphic Location: Zone 5

Size and Thickness: $205 \times 185 \times 10 \mathrm{~cm}$

Description: Two components were present in this large and interesting feature (Fig. 12). A large concentration (approximately 130 separate valves) of mussel shells was found approximately $50 \mathrm{~cm}$ north of a pile of chipping debris. Included in this chipping debris were 5 cores and 117 flakes detached from the cobbles. Lying within the pile of debris was a quartzite hammerstone that had been fractured on one edge. Apparently none of the flakes had been removed (all could be refitted), and burial had been rapid and in situ. Both chert and mussels might be associated with a charcoal stain recorded approximately $1 \mathrm{~m}$ to the east as Feature 7 (Unit N1062 E875). A1though Feature 7 appeared at a depth of $98.50 \mathrm{~cm}$, it continued to $98.35 \mathrm{~cm}$, at which level a scattering of mussels and burned rock was noted. Additionally, Unit N1061 E873 revealed several possible grinding stone fragments at a depth of $98.55 \mathrm{~cm}$ and a bifacial tool, and cores at a depth of $98.25 \mathrm{~cm}$. Although stratigraphically separated by $30 \mathrm{~cm}$, these tools still present some interpretive possibilities for the cultural remains clustered around Feature 16.

Feature 17

Units: N1057 E861 (SE, SW Quads)/N1055 E861

Depth: $97.35-97.25 \mathrm{~cm}$

Stratigraphic Location: Zone 2

Size and Thickness: $130 \times 111 \times 10 \mathrm{~cm}$

Description: One of the most complex and productive features once again occurred in Zone 2, $3 \mathrm{~m}$ west of Feature 2. Again, no intentional shaping of the feature was discernible in cross section, although a scattering of burned soil and charcoal occurred throughout the snails, mussels, and lithic debitage. Charcoal was collected but not dated.

The feature was apparently the focal point of tool production and food preparation. Associated with the soil discoloration and charcoal flecks were approximately 200 chert flakes, many of which were thinning flakes. Tools found in association with the feature included two cores, a uniface, two flakes with modified edges, two thin concave base bifaces, and a thick biface. Fire-fractured chert, sandstone, and burned umbo and soil fragments were 


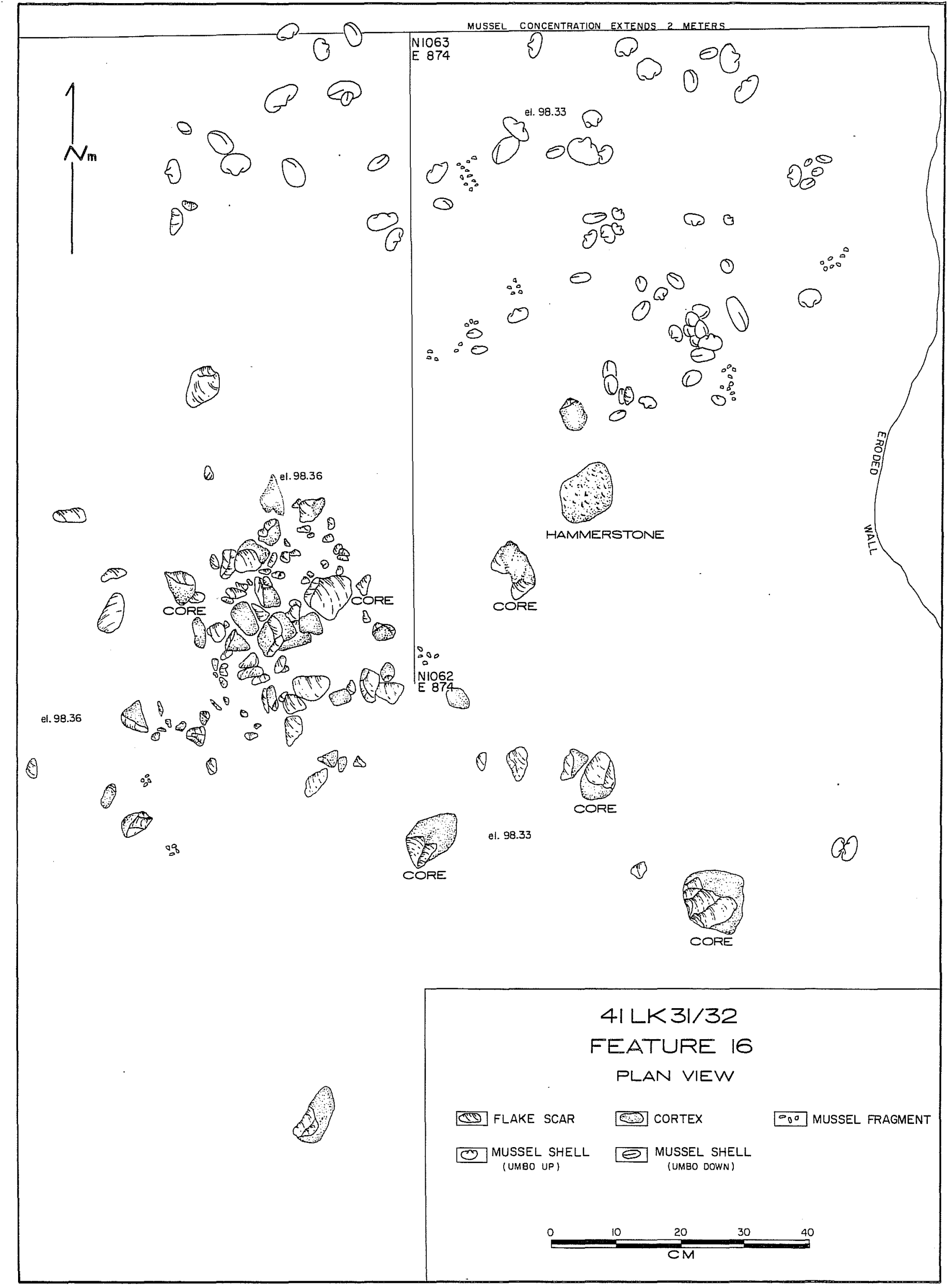

Figure 12. Plan View of Feature 16. 
loosely intermixed with the tools and flaking debris. Bone fragments were also noticed in the debris.

Feature 18

Unit: N1061 E873

Depth: $98.00-97.95 \mathrm{~cm}$

Stratigraphic Location: Contact of Zone 4 and Zone 5

Size and Thickness: $100 \times 65 \times 12 \mathrm{~cm}$

Description: Feature 18 was composed of a semicircular concentration of burned chert and siltstone. The stones were not grouped, instead being somewhat scattered. The soif beneath the feature showed evidence of heat coloration and charcoal mottling, al though no tools or debitage were found in direct association. Feature 19, 2 m north of Feature 18 in Unit N1063 E873, is stratigraphically associated.

Feature 19

Unit: N1063 E873

Depth: $97.85-97.65 \mathrm{~cm}$

Stratigraphic Location: Contact of Zone 4 and Zone 5

Size and Thickness: $35 \times 45 \times 15 \mathrm{~cm}$

Description: This small concentration of burned chert and siltstone was one of the few features that exhibited a shallow basin-shaped profile (Fig. 6,b). Although loosely constructed, several chert flakes and charcoal were associated, as wel1 as mussel shells and a concentration of Rabdotus snails extending northwest into Unit N1065 E873. Feature 18 is at the same stratigraphic level.

\section{Feature 20}

Unit: N1065 E875

Depth: $97.85-97.75 \mathrm{~cm}$

Stratigraphic Location: Zone 2

Size and Thickness: $197 \times 122 \times 5 \mathrm{~cm}$

Description: The feature was a dispersed cluster of burned siltstone associated with a scatter of mussel shells. A biface fragment found $2 \mathrm{~cm}$ above the burned rocks was the only associated artifact. Charcoal was present and collected for radiocarbon dating. Burned soil was distinct in the area of the rock scatter, but no basin was discernible in cross section.

Mussel shells (approximately 80 ) associated with the rock scatter were unburned and not intermixed with the rocks. Several Rabdotus snails and flakes were strewn within the rocks, but were not burned.

Stratigraphically, the feature is related to Features 2, 3, and 10 also located in Zone 2 . 
Summary

Features can be grouped into several categories based on form, function, and associations of cultural materials.

Features $2,3,8,12,13,14$, and 17

These features are characterized by $i 11$-defined horizontal boundaries, 1ittle or no structure in cross section, and evidence of a variety of functions occurring in the immediate confines of the feature. Feature 17 might be considered the holotype of this category as it contained evidence of chert tool production (biface failures and thinning flakes), food preparation (Rabdotus snails, mussel shells, charcoal flecks, and bone fragments), and some unspecified processing evidenced by edge worn flakes. It is assumed that the presence of burned rocks (sandstone, siltstone, and chert) in these features constitutes a hearth function in addition to the other activities.

Features 6, 11, 16, and 19

These features characteristically exhibited a single (or limited) function and a well-structured vertical and horizontal form.

Features 6 and 11 were remarkably similar in structure and size. Each was roughly $1 \mathrm{~m}$ in diameter and composed of tightly packed, fire-fractured chert cobbles. Neither was directly associated with tools or concentrations of mussel shells or snails. Finally, each exhibited a charcoal layer beneath the chert but there was no evidence of a prepared basin or pit.

Three aspects of this type of feature suggest a highly specialized function: chert cobbles were conspicuously selected and arranged; no tools or associated cultural debris was found in or near either feature; and chert spalls, results of thermal fractures in the cobbles, were concentrated within the feature and absent beyond the boundary of the burned cobbles. All three suggest considerable time spent in preparing the feature. The lack of associated cultural evidence suggests processing of whatever was cooked took place elsewhere on the site or, perhaps, at the locality of procurement.

Feature 16, possibly the most significant cultural feature uncovered, represents a cluster of chert cobbles and flakes located in Units N1061 E873 and N1063 E873. A cluster of five broken chert cobbles, one hammerstone, and approximately 117 flakes were present. The central pile of flakes, chips, and chunks was surrounded by discarded cores and core fragments. Apparently, an aboriginal flintknapper was testing the cobbles for quality, and they were discarded after several blows to each. None of the cores were exhausted. Flakes were being detached from cores without prepared platforms, and none of the flakes appear to have been taken after removal from the core. The hammerstone, a metamorphic stream cobble weighing slightly over a pound, was fractured (and presumably ruined) at an angle to the impact scars.

This extraordinary glimpse of a lithic reduction sequence implies that in this period in the site's history at least some raw material was being returned from procurement areas for processing. Furthermore, discrete function areas 
were being utilized in contrast to Features 2 and 17, but similar to Features 6 , 11 , and 19.

Mussel shell associated with the feature by level was included with the feature plan and number, but could well have been associated with an unexcavated feature north of the excavated units.

Feature 19 was the only feature to exhibit a prepared, basin-shaped profile. Construction is generalized, containing loosely arranged burned chert and sandstone, chert, charcoal, and mussel and snail shells. No tools were associated.

Features $1,7,9,10,15,18$, and 20

Seven features recovered were scattered in appearance, having no definitive structure in horizontal or vertical dimensions. These features tended to be associated with charcoal and dispersed burned rocks. Occasionally, mussel shells and Rabdotus snails were among the scatter but never, for example, in the concentrations that characterized Features 2 and 17. These features were considered to have been hearths (associated burned rock and charcoal) that were disturbed. Human action, such as cleaning a hearth, might create the scatter and soil stain observed between Features 1 and 10, al though animal disturbance and erosion could also be involved.

Features 4 and 5

These features were previously mapped in the profile of TPC-364. Their extent and full associations were not fully explored during mapping in the testing phase, primarily due to their location. Erosion subsequently destroyed the features.

\section{ARTIFACT ANALYSIS}

A1 1 excavated and surface-collected materials were returned to the Archaeology Laboratory at UTSA for analysis and storage. Lab personnel assisted in sorting excavated materials into categories determined by the range of artifacts and material types recovered. Soil samples, phytoliths, mussel shells, bone, and charcoal were also separated for distribution to consultants and analytical laboratories.

Final sorting and counting of field-sorted material preceded analysis. In a 11, 91 categories of material types were considered and 14 additional categories for weights of stone and shell were used. The final listing of all counts was computerized to yield a quantitative readout of the 105 total categories by $1-\mathrm{m}^{2}$ units and levels (see Appendix II).

Lithic analysis was approached from two directions. Debitage such as flakes, chips, and chunks were sorted into primary flakes, secondary flakes, tertiary flakes, and chips. Each of the flakes was examined for traces of edge wear, battering, gloss or hafting. Lithic tools were grouped by categories devised by Ha11, Black, and Graves (1982) and then examined for evidence of edge wear. 
Lithic Tools

This section on lithic tools involves artifacts grouped into six broad categories: bifaces (including dart points), unifaces (including gouges), cores, hammerstones, retouched flakes, and ground stone. These tools were all formed from siliceous stone readily available in the Uvalde gravels and Catahoula Formation exposed throughout the Frio River drainage. Chert gravels, petrified wood, and metamorphic gravel occurred in large deposits along the margins of the eroded uplands and in stream deposits. No tool excavated during either of the excavations at 41 LK $31 / 32$ was of a raw material not presently obtainable within the Frio River drainage.

Analysis of the tools began by sorting tools into categories based on visually determined forms. Utilization of this technique seeks to avoid "pigeonholing" of artifacts into popular categories--for example, Clear Fork gouges or Pedernales dart points--and attempts to establish functional categories instead. Similar approaches to lithic analys is can be found in Hester (1971) and Lynn, Fox, and 0'Malley (1977). Published artifact names were applied where types were readily ascertained to coincide with the literature.

Lithic categories used in this section were modified to correlate with categories established for the Choke Canyon project as a whole (Hall, Black, and Graves 1982). A comprehensive list of categories for the entire project was established by Grant D. Hall after viewing artifacts from all tested Choke Canyon sites. Ha17's categories contain al1 artifacts from 41 LK $31 / 32$ and should be consulted to augment the categories listed herein. Categories listed below pertain only to those inclusive of 41 LK $31 / 32$ artifacts and were derived from Hall's definitions.

\section{Cores (46 specimens)}

Cores are defined herein, as a cobble or other piece of raw material from which a flake or flakes have been removed. Flake removal was for the purpose of tool production. Table 3 presents the provenience of cores in each group.

Hall (ibid.) 1isted 10 groups of cores:

Group 1. Natural Platform

Group 2. Bidirectional, Natural, and Prepared Platforms

Group 3. Multidirectional, Natural, and Prepared Platforms, Single and Multiple Facets

Group 4. Unidirectional, Prepared Platforms, Single Facet

Group 5. Multidirectional, Natural and Prepared Platforms, Single Facet

Group 6. Core Nuclei

Group 7. Flat, Circular to Elliptical in Outline, Unifacially Cortex Covered

Group 8. Tested Cobbles

Group 9. Core Fragments

Group 10. Unmodified Cobbles

Of these 10 groups, numbers 5 and 10 were not recovered at 41 LK 31/32. 
Cores (continued)

Group 1. Natural Platform (8 specimens)

Cores in this group are characterized by flaking which utilizes the outer cobble cortex as the striking platform (Fig. 13,g). Most of these cobbles were irregular in outline, multidirectionally flaked, and retained $80 \%$ to $95 \%$ of the cobble cortex.

Group 2. Bidirectional, Natural, and Prepared Platforms (1 specimen)

Cores in this category were struck along a single edge or face using a cortex platform for the initial flakes, then using the flake scar as a platform to remove flakes at a $90^{\circ}$ angle to the original point of flake removal. A single specimen was recovered from 41 LK $31 / 32$ (Fig. 13,f).

Group 3. Multidirectional, Natural, and Prepared Platforms, Single and Multiple Facets (13 specimens)

Many cores recovered at 41 LK $31 / 32$ were of this category. As the category suggests, flakes were removed multidirectionally utilizing natural and cortex platforms (Fig. 13,h). Cortex remains on $90 \%$ of the core. Large flakes that had been removed were also included in this category and often retained no cortex.

Group 4. Unidirectional, Prepared Platform, Single Facet (5 specimens)

Flaking of these cores was characterized by unidirectional flakes perpendicular to a prepared platform, usually a single facet platform. Cobbles and flakes were represented, often retaining $50 \%$ to $80 \%$ of the cortex. Cores often termed polyhedral are included in this bracket (Fig. 13,d).

Group 6. Core Nuclei (12 specimens)

Twelve examples of this category made it the second most numerous recovered at $41 \mathrm{LK} \mathrm{31/32.} \mathrm{Often} \mathrm{termed} \mathrm{exhausted} \mathrm{cores,} \mathrm{these} \mathrm{specimens} \mathrm{are} \mathrm{sma11,} \mathrm{irregu-}$ lar in shape, multidirectionally flaked, and often show excessive battering and step-fracturing on the edges ( $F i g .13, a, c$ ).

Group 7. Flat, Circular to Elliptical in Outline, Unifacially Cortex Covered (1 specimen)

These are often elliptical or biconvex in outline with one face covered with cortex and the other with flake scars. The cores appear to be split cobbles or flakes as compared to other examples from the Choke Canyon area ( $\mathrm{HaTl}$, B1ack, and Graves 1982). 
TABLE 3. PROVENIENCE OF CORES RECOVERED IN EXCAVATIONS*

\begin{tabular}{|c|c|c|c|}
\hline UNIT & GROUP & LEVEL & ELEVATION \\
\hline N1056 E863 & 1 & 2 & $99.25-99.00$ \\
\hline N1056 E863 & 1 & 9 & $97.73-97.60$ \\
\hline N1062 E875 (2 specimens) & 1 & 3 & $99.25-99.00$ \\
\hline N1059 E863 & 1 & 12 & $97.55-97.45$ \\
\hline N1063 E873 (4 specimens) & 1 & 4 & $98.35-98.25$ \\
\hline N1059 E861 & 2 & 12 & $97.65-97.55$ \\
\hline N1055 E863 & 3 & & $97.20-97.15$ \\
\hline N1062 E875 & 3 & 2 & $99.50-99.25$ \\
\hline N1062 E875 & 3 & 3 & $99.25-99.00$ \\
\hline N1063 E875 & 3 & & Zone 2, Feature 10 \\
\hline N1064 E875 & 3 & & Zone 2, Feature 10 \\
\hline N1057 E861 & 3 & 16 & $97.35-97.25$ \\
\hline N1059E863 & 3 & 8 & $97.95-97.85$ \\
\hline N1059 E865 & 3 & 9 & $97.85-97.75$ \\
\hline N1061 E873 & 3 & 6 & $98.25-98.15$ \\
\hline N1061 E873 & 3 & 12 & $97.65-97.55$ \\
\hline N1063 E873 & 3 & 4 & $98.35-98.25$ \\
\hline N1065 E875 & 3 & 2 & $98.55-98.45$ \\
\hline N1117 E999 & 3 & 7 & $99.10-98.90$ \\
\hline N1056 E863 & 4 & 1 & $99.60-99.25$ \\
\hline N7061 E873 & 4 & 7 & $98.15-98.05$ \\
\hline N1065 E875 & 4 & 10 & $97.75-97.65$ \\
\hline N1083 E1108 (2 specimens) & 4 & 7 & $98.55-98.35$ \\
\hline
\end{tabular}

\#provenience of subsurface recoveries not provided for Group 9. 
TABLE 3. (continued)

UNIT

$\begin{array}{llll}\text { N1056 E863 (2 specimens) } & 6 & 4 & 98.75-98.50 \\ \text { N1062 E875 } & 6 & 3 & 99.25-99.00 \\ \text { N1059 E861 } & 6 & 3 & 98.55-98.45 \\ \text { N1061 E873 } & 6 & 6 & 98.25-98.15 \\ \text { N1083 E1108 } & 6 & 7 & 98.55-98.35 \\ \text { N1083 E1108 } & 6 & 8 & 98.35-98.15 \\ \text { N1083 E1108 (3 specimens) } & 6 & 9 & 98.15-97.95 \\ \text { N1083 E1108 } & 6 & 10 & 97.97-97.75 \\ \text { N1083 E1108 } & 6 & 11 & 97.75-97.55 \\ \text { N1055 E861 } & 7 & & \text { Feature } 17 \\ \text { N1116 E998 } & & & 99.10-98.90\end{array}$


Figure 13. Cores. a, Group 6, core nuclei; b, Group 9, core fragments; c, Group 6, core nuclei; d, Group 4, unidirectiona 1, prepared platform, single facet; $e$, Group 8 , tested cobbles; $f$, Group 2, bidirectional, natural, and prepared platform; g, Group 1, natural platform; h, Group 3, multidirectional, natural, and prepared platforms, single and multiple facets. 


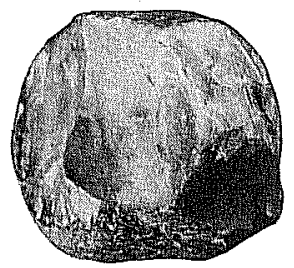

a
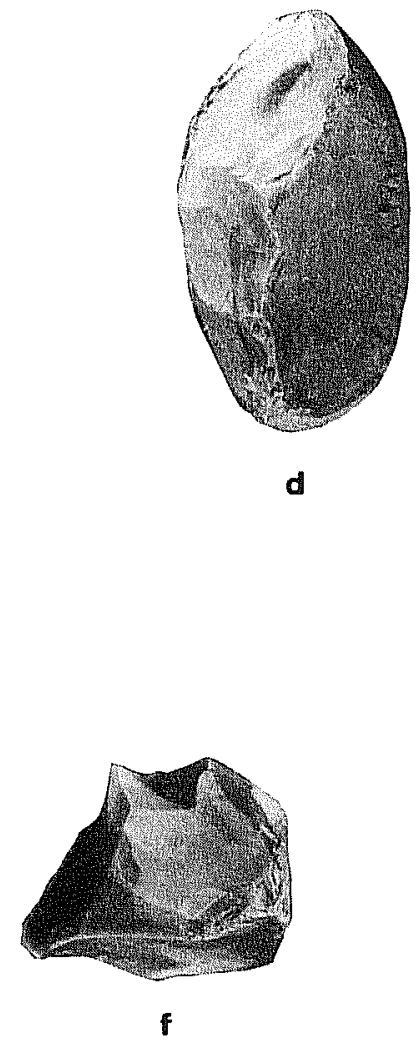

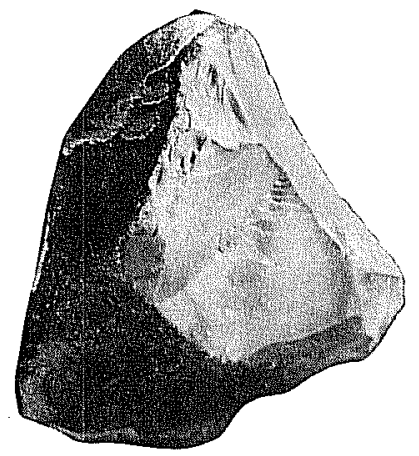

b

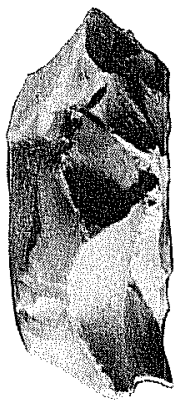

c

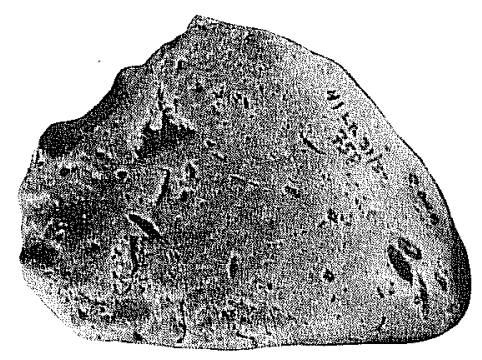

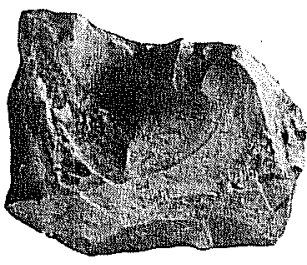

$\mathbf{g}$

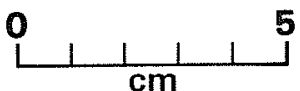

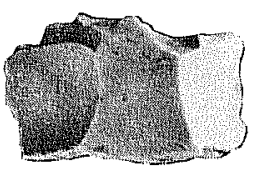

h 
Cores (continued)

Group 8. Tested Cabbles (1 specimen)

Flakes (one to four) have been detached from these cobbles, presumably to test material quality (Fig. 13,e). Cores in this category might also be labeled discards.

Group 9. Core Fragments (5 specimens)

Group 9 contains core fragments not classifiable into any of the above groups. Most are believed to be remnants of shattered cores and trimmings resulting from platform preparation and general shaping procedures (Fig. 13,b).

\section{Thick Bifaces (20 specimens)}

Hall (ibid.) defines thick bifaces as a subclass of bifaces in general, characterized by: 1) $1.3 \mathrm{~cm}$ or greater in thickness; 2) having 10 to $30 \mathrm{flake}$ scars, each greater than $1 \mathrm{~cm}^{2}$; 3) lack a finished or readily apparent form and wear patterns indicative of a functional tool. Whereas Hall assumes these to be discards or manufacturing failures, their potential for use on nonabrasive tissue or foliage is a possibility. Cortex is often retained on portions of the thick bifaces, and both cobbles and flakes were used as the preform of the tool. Hall also notes that thick bifaces could have functioned as cores, as well as unfinished steps in the bifacial reduction sequence. Hall identified the following nine groups:

Group 1. Large, Crudely Flaked Oval to Elliptical

Group 2. Elliptical

Group 3. Oval to Subcircular

Group 4. Circular to Subcircular

Group 5. Triangular

Group 6. Fragments with Pointed Ends

Form 1. Elongate

Form 2. Triangular

Group 7. Fragments with Rounded Ends

Form 1. Subcircular to Oval

Form 2. Large, Broad, Thin Fragments

Form 3. Elliptical

Form 4. Remnant Cortex Striking Platforms

Group 8. Odd and Miscellaneous Forms-Whole and Fragmentary

Group 9. Lateral and Medial Fragments

Group 4 is absent at 41 LK 31/32, as is Group 6 Form 1, Group 7 Form 3, and Group 8. Table 4 presents the provenience of the thick bifaces excavated. 
TABLE 4. PROVENIENCE AND METRIC DATA OF THICK BIFACES

UNIT LEVEL ELEVATION

DIMENSIONS $(\mathrm{cm})$

WEIGHT $(\mathrm{gm})$

Group 1. Large, Crudely Flaked Oval to Elliptical

$\begin{array}{llllll}\text { N1064 E877 } & 11 & 97.65-97.38 & 4.7^{*} \times 5.5^{*} \times 2.4 & 80.7^{*} \\ \text { surface } & & 8.1 \times 5.8 \times 2.4 & 88.8\end{array}$

Group 2. El1iptical

N7083 E1108 8

surface

$98.35-98.15$

$8.4 \times 3.6 \times 1.8$

57.1

$6.4 \times 3.6 \times 2.3 \quad 51.6$

Group 3. Oval to Subcircular

$\begin{array}{lcllll}\text { N1062 E875 } & 2 & 99.50-99.25 & 6.7 \times 4.3 \times 1.9 & 53.0 \\ \text { surface } & & 5.6 \times 4.9 \times 1.4^{*} & 36.7^{*} \\ \text { surface } & & 6.4 \times 4.7^{*} \times 1.4 & 37.7^{*}\end{array}$

Group 5. Triangular

N1055 E861 (Feature 17)

$8.1 \times 5.0 \times 2.0 \quad 87.0$

Group 6, Form 2. Fragments with Pointed Ends, Triangular

N1056 E863 $1199.60-99.25$

surface

surface

$\begin{array}{ll}--- & --- \\ --- & ---\end{array}$

Group 7, Form 1. Fragments with Rounded Ends, Subcircular to 0va1

surface $4.5^{*} \times 5.4 \times 1.8 \quad 43.6^{*}$

Group 7, Form 2. Fragments with Rounded Ends; Large Broad, Thin Fragments N1065 E873 $897.95-97.85 \quad 4.6^{*} \times 7.1 \times 2.2 \quad 62.0$ *

Group 7, Form 4. Fragments with Rounded Ends, Remnant Cortex Striking Platform surface $5.0^{*} \times 4.1 \times 1.3 \quad 32.5^{*}$

Group 9. Lateral and Medial Fragments

N1064 E877

N1083 E1108

N1083 E7 108

N7083 E1 108

N1116 E998

$\begin{array}{rr}11 & 97.65-97.38 \\ 6 & 98.75-98.55 \\ 6 & 98.75-98.55 \\ 7 & 98.55-98.35 \\ 7 & 99.10-98.90\end{array}$

surface

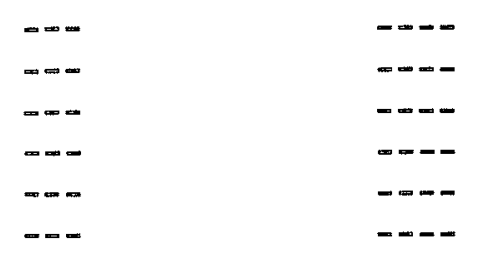


Figure 14. Thick Bifaces. a, Group 7 Form 1, fragments with rounded end, subcircular to oval; b, Group 7 Form 2, fragments with rounded end, large, broad, thin fragments; c, Group 7 Form 4, fragments with rounded end, remnant cortex striking platforms; d,e,f, Group 6 Form 2, fragments with pointed ends, triangular; $g, h, i$, Group 3 , oval to subcircular; $j, k$, Group 1, large crudely flaked oval to elliptical; 1,m, Group 2, elliptical. 

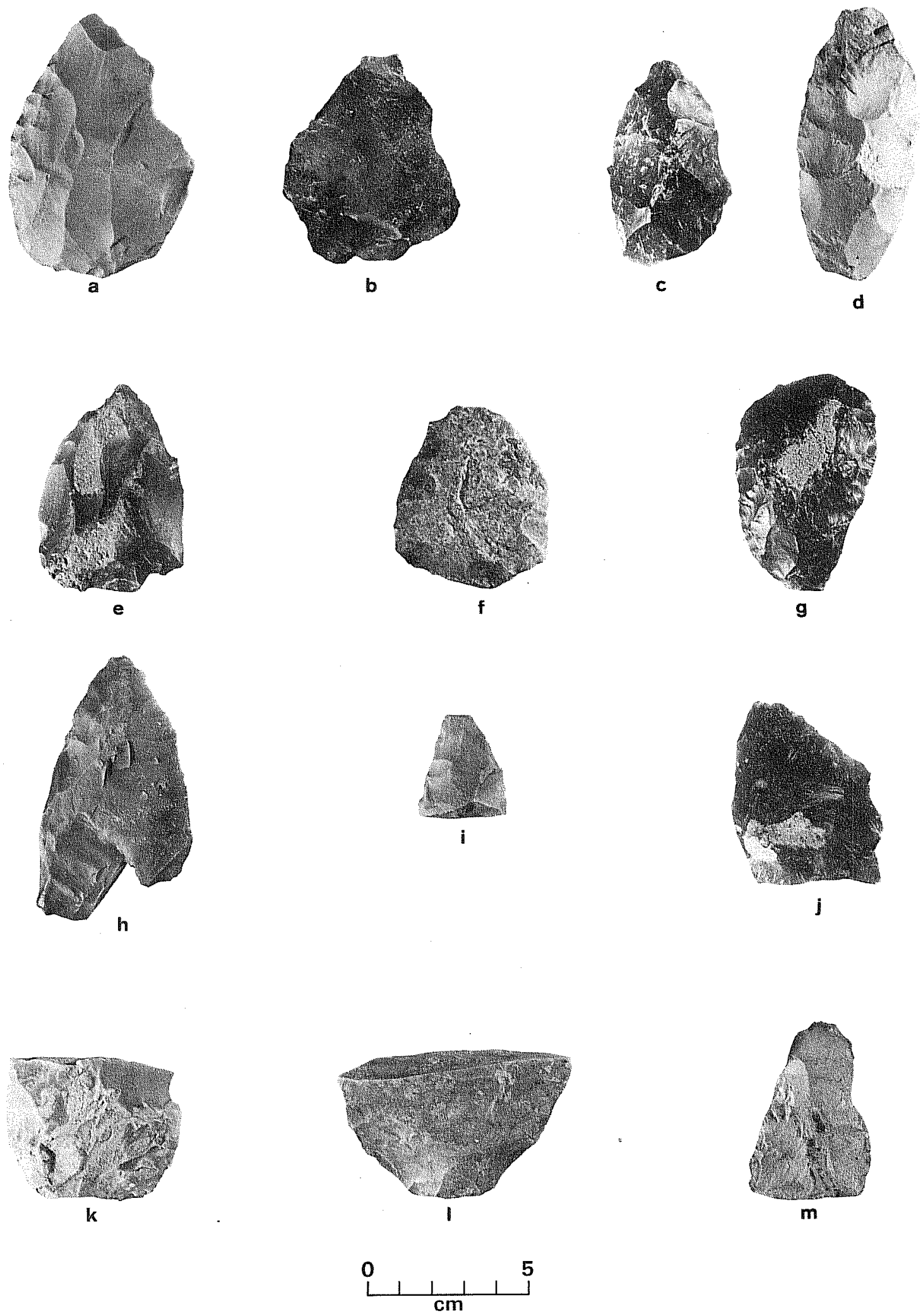
Thick Bifaces (continued)

Group 1. Large, Crudely Flaked Oval to Elliptical (2 specimens)

Flakes on these bifaces were detached from cortex or prepared platforms, leaving an oval, elliptical, or subrectangular form ( $F i g .14, j, k$ ). Centrally located ridges resulting from repeated step-fracturing are common. The bifaces tended to be longer than wide and are biconvex in cross section. Cortex was often present on one side, occasionaliy on both.

Group 2. Elliptical (2 specimens)

Bifaces in this category resemble Group 1, varying in the following characteristics: smaller and more elongated than Group 1; a more defined, less irregular edge form; and thinner in cross section, though still biconvex (Fig. $14,7, \mathrm{~m}$ ).

Group 3. Oval to Subcircular (3 specimens)

Widths tend to equal or closely approximate length in this category. Cross sections are biconvex to plano-convex, and cortex is often retained on one face (Fig. $14, g-i$ ).

Group 5. Triangular (1 specimen)

This grouping includes bifaces of triangular form with length approximately twice the width and a biconvex cross section (Fig. 16,p). A single example of this category came from 41 LK $31 / 32$ excavations.

\section{Group 6. Fragments with Pointed Ends (3 specimens)}

Elongate (Form 1) and Triangular (Form 2) fragments comprise this class of tools. In general, these tools are indicative of manufacturing or use failure debris of Group 2 (e1liptical) and Group 5 (triangular) Thick Bifaces. Form 1 was not in evidence at 41 LK $31 / 32$ while 3 specimens of Form 2 were recovered (Fig. 14,d-f).

\section{Group 7. Fragments with Rounded Ends (3 specimens)}

This generalized category contains four forms. Form 1 (Fig. 14,a) represents breakage from Group 2 and 3 bifaces, whereas Form 2 (Fig. 14,b) resembles failures in the Group 4 Form 3 Thin Biface category. Form 3 represents a possible variation on Group 2 breakage where bifaces broke longitudinally. Form 3 was not recovered at $41 \mathrm{LK} 31 / 32$. Form 4 (Fig. 14,C) bifaces retained a cortex striking platform on the rounded end. 
Thick Bifaces (continued)

Group 9. Lateral and Medial Fragments (6 specimens)

These unclassifiable fragments result from use or manufacturing failure.

Thin Bifaces

Included within this category are the stone tools commonly referred to as dart points, arrow points, and knives. Many may be preforms or manufacturing failures. These tools represent pressure flaking as well as percussion techniques, a thin cross section (1ess than $1.3 \mathrm{~cm}$ as established by Ha11), and, usualiy, a complete absence of cortex.

Only groups and forms represented at 41 LK $31 / 32$ will be discussed, and Table 5 provides the proveniences and measurements. Please consult Hall's (Hall, Black, and Graves 1982) extensive discussion for categories not included here.

Group 1. Stemmed (8 specimens)

Form 1. Large with Straight Stems (2 specimens)

This group represents stemmed bifaces and dart points characterized by nearparallel stem form.

Specimen 1. Straight to convex edges with a concave base characterize this surface-collected dart point (Fig. 15,a).

In form it corresponds to the Pedernales point as defined by Suhm and Jelks (1962:235-238). Reworking of one edge after the formation of a light patina was evident (corresponds to Hall's Specimen 3).

Specimen 2. Triangular blade with convex edges and a we11-developed point characterize this thin biface, along with a convex base and poorly developed shoulders (Fig. 15, b). Recovery of this presumed dart point was in zones bracketed between radiocarbon dates of 3380 B.C. and 2340 B.C. (this specimen equates with Hall's Specimen 9). I have linked this specimen to the Nolan type (Suhm and Jelks 1962:225-226).

Form 2. Large with Contracting Stems (4 specimens)

Specimens 1 and 2. Two specimens of dart points corresponding to the Morhiss type were surface collected at $41 \mathrm{LK} 31 / 32$ (Fig. 15, C,d). The bifaces were characterized by convex blade edges, a weakly developed distal point (on the complete example), slightly developed shoulders, 
TABLE 5. PROVENIENCE AND METRIC DATA FOR STEMMED THIN BIFACES +

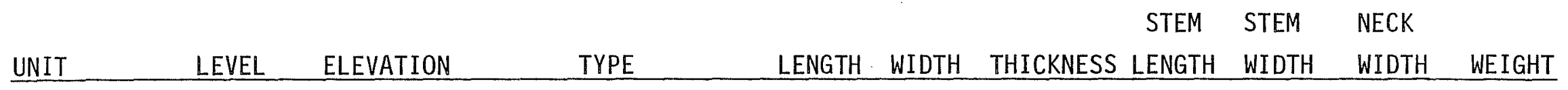

Group 1, Form 1. Large with Straight Stems

$\begin{array}{lllllllllll}\text { surface } & & & \text { Pedernales } & 7.1 & 2.8 & 0.6 & 2.0 & 2.1 & 2.1 & 11.0 \\ \text { N1058 E864 Zone 4 } & 97.69 & \text { Nolan (?) } & 5.8 & 2.5 & 0.7 & 1.5 & 2.1 & 2.0 & 11.4\end{array}$

Group 1, Form 2. Large with Contracting Stems

$\begin{array}{llllllllc}\text { surface } & \text { Morhiss } & 5.5 & 3.0 & 1.0 & 1.8 & 2.6 & 2.6 & 17.8 \\ \text { surface } & \text { Morhiss } & 4.8 & 2.9 & 0.9 & 1.7 & 2.2 & 2.2 & - \\ \text { surface } & & 5.0^{*} & 1.9 & 0.7 & 0.8^{*} & 1.4 & 1.4 & 7^{*} \\ \text { surface } & & 5.3 & 2.5 & 1.0 & 2.0 & 1.8^{*} & 1.8^{*} & -\end{array}$

Group 1, Form 3. Large with Expanding Stems

$\begin{array}{lllllllll}\text { N1057 E861 } & 97.65-97.55 & 4.7 & 2.9 & 0.6 & 1.4 & 2.3 & 2.0 & 8.8\end{array}$

Group 1, Form 6. Unclassifiable Fragments of Large Stemmed Bifaces

$\begin{array}{llllll}\text { N1059 E865 } & 8 & 97.95-97.85 & 3.4^{*} & 2.8 & 7.9\end{array}$ 
Thin Bifaces (continued)

and strongly convex bases. Fox (1979:62) recovered Morhiss material in Goliad County radiocarbon dated at 1250 B.C. to 500 B.C. (equals Ha11's Specimens 4 and 8).

Specimen 3. A slender, leaf-shaped point, missing the base and distal tip represented an untyped, presumed dart point (Fig. 15,e). Made of fine-grained, cream-colored chert, it was characterized by moderately convex edges-unevenly flaked--and a prominent, broken tip (equals Hal1's Specimen 11).

Specimen 4. This fragmented specimen was flaked from a coarse-grained gray chert which showed signs of thermal fracturing (Fig. 15,f). Surface collected, it exhibited a straight stem and flat base with moderate shoulders. The distal tip and one shoulder were missing, and the dart point could not be readily assigned to a defined type (equates with Hal1's Specimen 18).

Form 3. Large with Expanding Stems (1 specimen)

Bifaces of this category are again presumed to represent dart points.

Specimen 1. This dart point was excavated as part of Feature 14 at 41 LK $31 / 32$. Lateral edges were straight with slightly developed shoulders and a flat base

(Fig. 15,g). Some beveling was evident on one edge. The top was blunt and showed signs of dulling or reworking. Blade shape was generally triangular. I have tentatively linked the specimen to the Lange type (Suhm and Jelks 1962:203-204). Stratigraphic position was between the radiocarbon dates of 2340 B.C. and 3380 B.C., though perhaps much closer to the latter date in terms of excavation levels (equates with Ha11's Specimen 26).

Form 6. Unclassifiable Fragments of Large Stemmed Bifaces (1 specimen)

Fragments in this class showed evidence of having been a stemmed biface prior to breakage.

Specimen 1. This untyped presumed dart point showed

evidence of an impact fracture which had removed the

tip, and an irregular flute across one face (Fig. 15,h).

The remnant showed evidence of moderate shoulders and a

shallow base (equals Hall's Specimen 3). 
Figure 15. Thin Bifaces. a,b, Group 1 Form 1, stemmed, large with straight stems; c,d,e,f, Group 1 Form 2, stemmed, large with contracting stems; $g$, Group 1 Form 3, stemmed, large with expanding stems: $h$, Group 1 Form 6, stemmed, unclassifiable fragments of large stemmed bifaces; $i, j, k, 1$, Group 2 Form 1, unstemmed with straight bases, complete triangular: $m, n, 0, p$, Group 2 Form 2 , unstemmed proximal fragments with straight bases; $q, r, s, t, u$, Group 3 Form 2, unstemmed proximal fragments with concave bases; $v, w, x$, Group 4 Form 1, unstemmed with convex and semicircular bases, complete triangular; $y$, Group 4 Form 3, unstemmed oval to elliptica 1; $z, a a, b b$, Group 5, unstemmed leaf shaped. 


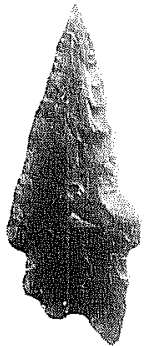

a

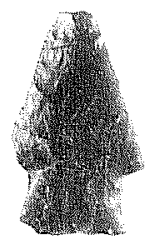

g

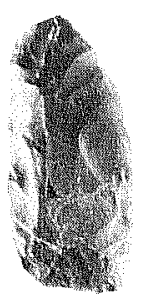

m

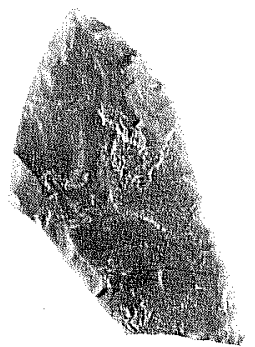

9
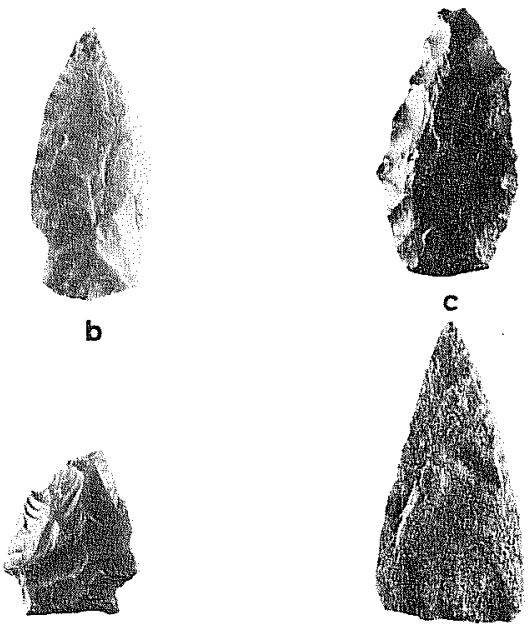

h

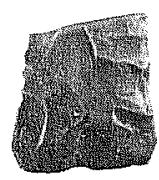

n

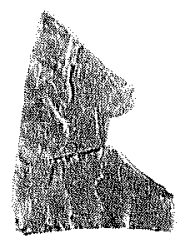

$r$

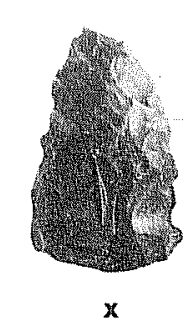

w
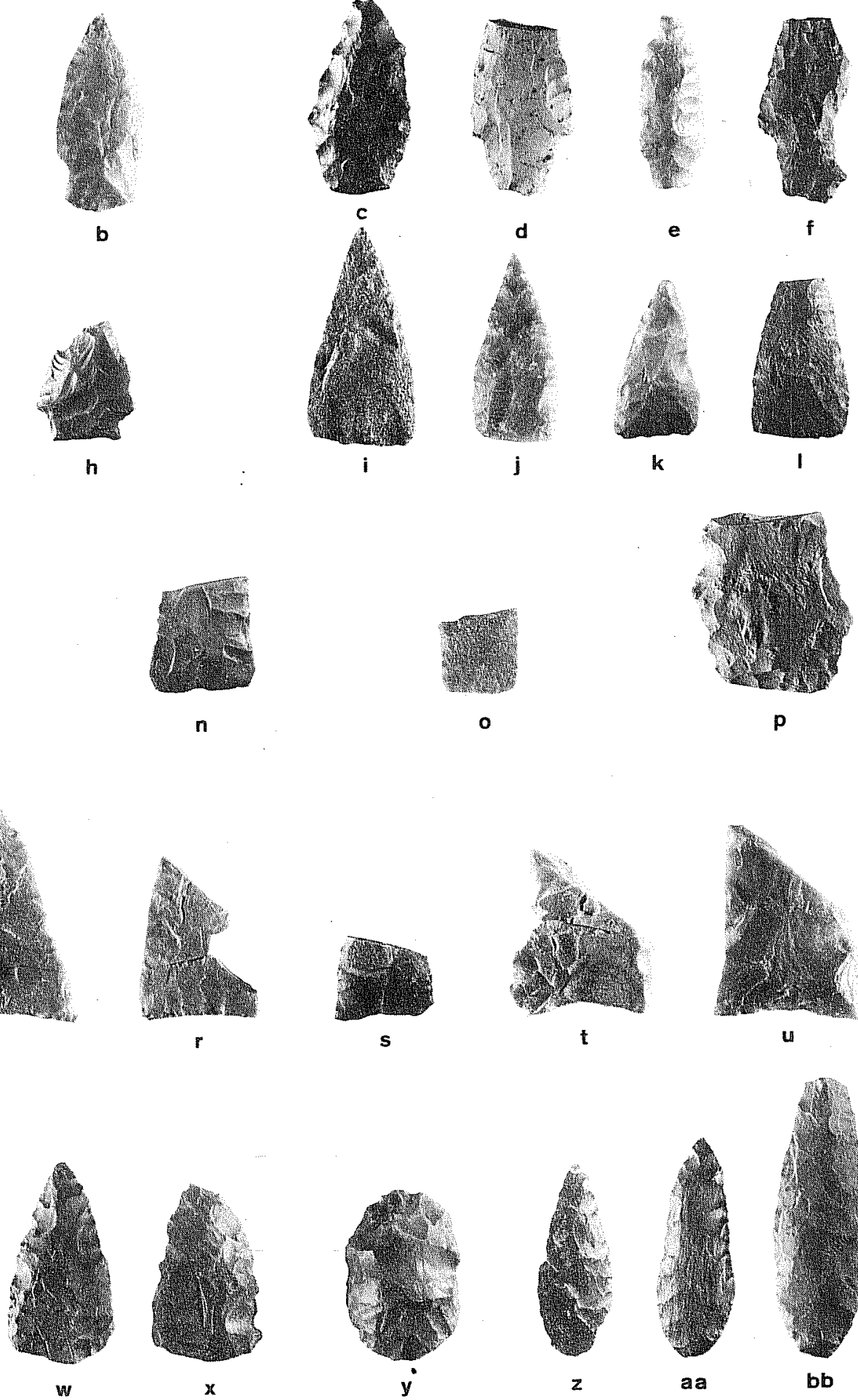

k

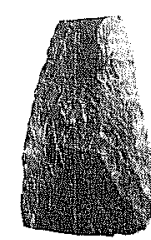

I
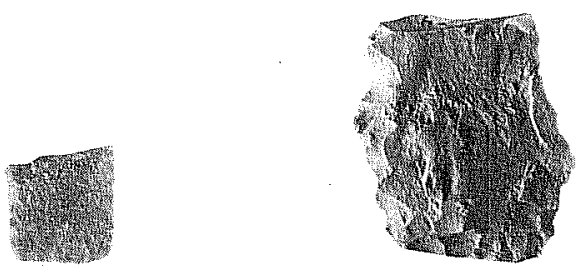

o

p

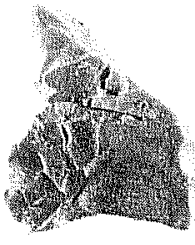

t

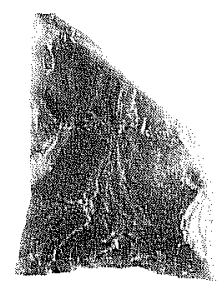

U
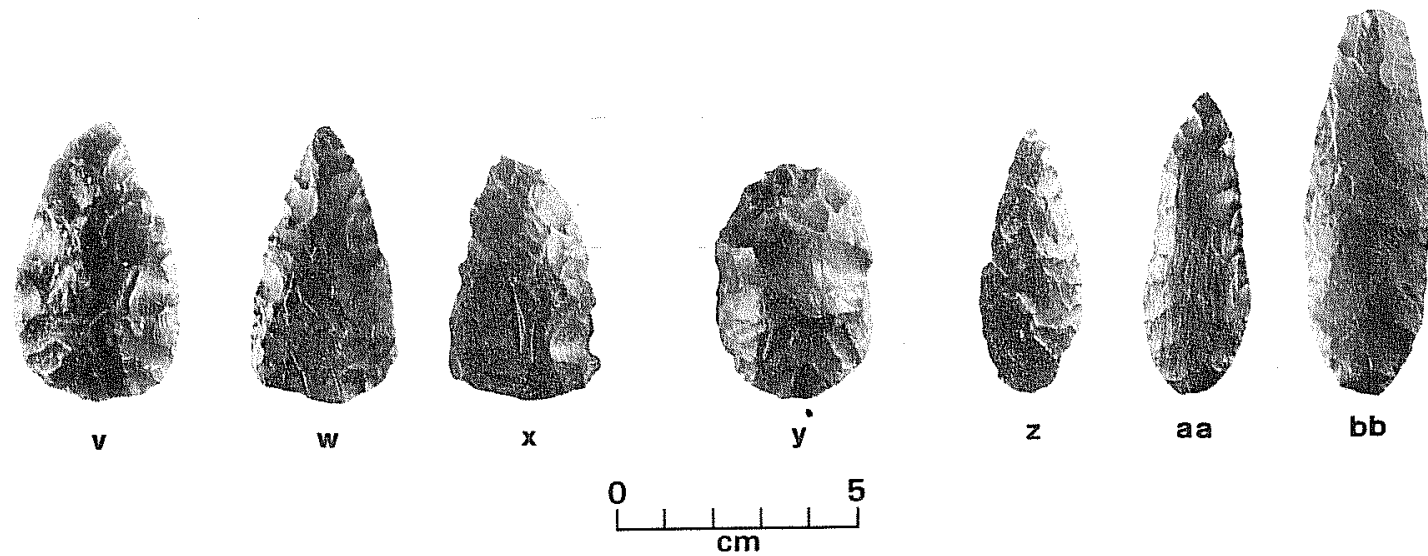
TABLE 6. PROVENIENCE AND METRIC DATA FOR UNSTEMMED THIN BIFACES RECOVERED IN EXCAVATIONS

Group 2, Form 1. Unstemmed with Straight Bases, Complete Triangular N950 E838

$$
2 \quad 100.10-99.90
$$

$5.4 \times 2.5 \times 0.8$

9.8

Group 2, Form 2. Unstemmed with Straight Bases, Proximal Fragments

$\begin{array}{lrrrrr}\text { N1057 E861 } & 3 & 98.65-98.55 & -\cdots & & -1- \\ \text { N1059 E861 } & 12 & 97.65-97.55 & 5.8 \times 2.6 & \times 1.1 & 15.7\end{array}$

Group 3, Form 2. Unstemmed with Concave Bases, Proximal Fragments

$\begin{array}{cccccc}\text { N1055 E861 } & 5 & 97.35-97.25 & * \times 4.2 \times 0.7 & 8.7 * \\ \text { N1055E861 } & 5 & 97.35-97.25 & * \times 4.4 \times 0.8 & 19.55^{*}\end{array}$

Group 4, Form 1. Unstemmed with Convex to Semicircular Bases, Complete Triangular N1059 E863 $10 \quad 97.75-97.65$

Group 4, Form 3. Unstemmed with Convex to Semicircular Bases, Oval to Elliptical N1059 E865 $9 \quad 97.85-97.75$ $\star x 1.7 \times$ *

Group 5. Unstemmed Leaf-Shaped $\begin{array}{lll}N 1117 \text { Eg99 } & 7 & 99.10-98.90\end{array}$

Group 9. Fragments with Pointed Ends

N1056 E863

N1055 E861

N7055 E861

N1059 E865

$\begin{array}{ll} & 97.25-97.20 \\ 6 & 97.25-97.15 \\ 6 & 97.25-97.15 \\ 8 & 97.95-97.85\end{array}$

$97.25-97.20$

$97.25-97.15$

$97.95-97.85$ 
TABLE 6. (continued)

\begin{tabular}{|c|c|c|c|c|}
\hline UNIT & LEVEL & ELEVATION & DIMENSIONS* $(\mathrm{cm})$ & WEIGHT* (gm) \\
\hline N1065 E875 & 9 & $97.85-97.75$ & $-\infty$ & --- \\
\hline N1083 E7108 & 6 & 98.7598 .55 & $-\infty$ & $-\infty--$ \\
\hline N1116 E998 & 6 & $99.30-99: 10$ & $-\infty$ & --- \\
\hline Group 10. & and $M$ & Fragments & & \\
\hline N1055 E863 & & 97.30 & $-\infty=$ & $-\infty-$ \\
\hline N950 E838 & 3 & $99.90-99.70$ & $\infty$ & --- \\
\hline N1055 E861 & 5 & & $-m-$ & $-\infty-\infty$ \\
\hline N1059 E863 & 14 & $97.35-97.25$ & $-\infty$ & $-\infty-$ \\
\hline N1063 E873 & 1 & $98.67-98.55$ & $-\infty$ & $-\infty-$ \\
\hline N1083 E7108 & 6 & $98.75-98.55$ & -- & $-\infty--$ \\
\hline N1083 E1108 & 8 & $98.35-98.15$ & $=-$ & $--\infty$ \\
\hline N1116 E998 & 7 & $99.10-98.90$ & -- & ---- \\
\hline N1116 E998 & 7 & $99.10-98.90$ & --- & --- \\
\hline
\end{tabular}


Thin Bifaces (continued)

Group 2. Unstemmed with Straight Bases (8 specimens, Table 6)

Form 1. Complete Triangular (4 specimens)

Bifaces within this group correspond to the Tortugas dart point type as described by Suhm and Jelks (1962:249). Point form is generally triangular with straight edges and a flat base (Fig. $15, i-1$ ). Longitudinal thinning flakes were evident on three of the four examples. Only a single point in this category was excavated, from level 2 of Unit N950 E838. A11 others were surface collected (corresponds to Hall's Specimens 1-46).

Form 2. Unstemmed Proximal Fragments with Straight Bases (4 specimens)

Specimens 1,2, and 3 are triangular in form, although incomplete due to manum facturing or use failure (Fig. 15, m-p). Specimen l (equals Hall's Specimen 11) is missing the distal third of the biface with straight edges. In overall form it resembles the Group 2 Form 1 triangular (or Tortugas), but the lack of basal thinning makes the possibility of a nondescript blank or preform feasible.

The two other bifaces in this category tend to be rectangular rather than triangular, with parallel convex to subconvex edges and flat bases. Specimen 2 (equals Ha11's Specimen 10) suggests the proximal portion of a finished tool of dart point size, thin and pressure flaked. Specimen 3 (corresponds to Hall's Specimen 45) is not pressure flaked and is complete except for a small portion of the distal tip. Battered platforms and hinge fracturing on one edge suggest this biface was a discarded preform.

Specimen 1 was recovered $35-45 \mathrm{~cm}$ below the surface in Unit N1057 E861; Specimen 3 was recovered from a depth of 235-245 cm in Unit N1059 E861. Specimens 2 and 4 were surface collected. In terms of radiocarbon dates, Specimen 1, resembling a Tortugas dart point, occurred almost $50 \mathrm{~cm}$ above the date of 2340 B.C. while the preform occurred roughiy $20 \mathrm{~cm}$ above the stratigraphic level from which the 3380 B.C. date was extracted.

Group 3. Unstemmed with Concave Bases (5 specimens)

Form 2. Unstemmed Proximal Fragments with Concave Bases (5 specimens)

These forms are wide, nonshouldered forms with slight to pronounced concave bases (Fig. 15,q-u). Edges range from convex to concave-convex. Specimens 1 and 2 (equals Hall's Specimens 3 and 7) were surface collected.

Specimens 3-5

( $\mathrm{Ha} 17$ 's 4,5 , and 6) were recovered from Feature 17 in Zone 2 of Unit N1055 E861.

Al1 of the Form 2 bifaces were characterized by well-finished proximal bases and a basal width suggestive of other than dart point function. Interestingly, 
Thin Bifaces (continued)

Specimens 3-5 exhibited we11-finished bases in conjunction with unused striking platforms and unthinned portions on the same fragment. This appears to suggest a critical function in base form, particularly in hafting. What this function might have been is problematical in the absence of edge wear on the three specimens. Feature 17 was located in Zone 2 and was therefore stratigraphically equal with the 3380 B.C. radiocarbon date.

Group 4. Unstemmed with Convex and Semicircular Bases (4 specimens)

Form 1. Complete Triangular (3 specimens)

The three bifaces in Group 4 Form 1 from 41 LK 31/32 are generally triangular in outline with convex sides and bases (Fig. $15, \mathrm{v}-\mathrm{x}$ ). Corners are rounded, and there is no evidence of basal thinning. Generally, these three specimens correspond to the Refugio dart point category in Suhm and Jelks (1962:241). Specimen 1 (corresponds to Hall's Specimen 6) was recovered at $1 \mathrm{~m}$ below surface in Unit N1056 E863 whereas Specimens 2 and 3 (corresponds to Ha11's 4 and 5) were surface collected.

Again, designation as a dart point is difficult with a generalized triangular biface, which could have easily functioned as a knife or a preform.

Form 3. Unstemmed Oval to Elliptical (1 specimen)

Collected from approximately $200 \mathrm{~cm}$ below ground surface in Unit 11059 E865, this oval, thin, roughly worked biface (Specimen 1) showed no edge wear

(Fig. $15, y)$. In the absence of other evidence, it is referred to as a preform or discarded tool failure.

\section{Group 5. Unstemmed Leaf Shaped (3 specimens)}

under this heading are slender with convex edges and blunt, round bases

(Fig. 15,z,aa,bb). Length is twice the width or more in every specimen from $41 \mathrm{LK} \mathrm{31/32.} \mathrm{Specimens} 1$ and 2 (corresponds to Hal7's 3 and 5) were surface collected. Specimen 3 (Hall's 4) was associated with Feature 12 in Unit $\mathrm{N} 1117$ E999, although no radiocarbon date was associated with that particular feature. Specimen 3 was chipped from finely textured petrified wood and was smooth along its proximal third and slightly serrated along the lateral edges. Leaf-shaped bifaces of this type resemble the Refugio and Lerma dart point types in Suhm and Jelks $(1962: 241,297)$.

\section{Group 9. Fragments with Pointed Ends ( 14 specimens)}

This category includes all distal tips, bases, and barbs from either tool failure, manufacturing error, or natural causes (Fig. 16,a-f). 
Figure 16. Thin Bifaces, Distally Beveled Bifaces and Unifaces, and a Thick Biface. $a, b, c, d, e, f$, Group 9, thin bifaces, fragments with pointed ends; g-0, distally beveled bifaces and unifaces ( $g, h$, Group 3 Form 2, short, broad, triangular to subrectangular-triangular, proximal end rounded; $i$, Group 8 Form 4, broad, flat, triangular; $j, k$, Group 4, small triangular to subtriangular; 1,m, Group 7 Form 4, distal fragments; $n$, Group 1, large triangular to subtriangular; 0 , Group 7 Form 2, short, broad, subrectangular to ova1); $p$, Group 5, thick biface, triangular. 


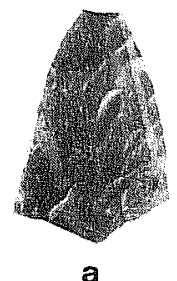

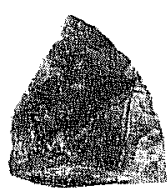

b

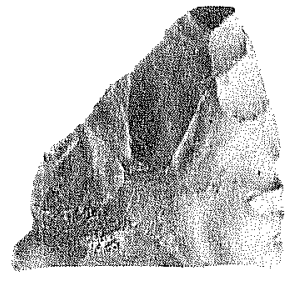

e

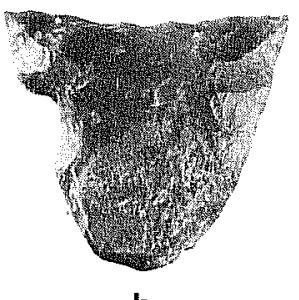

h

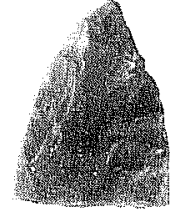

c

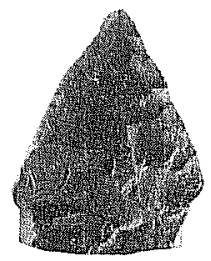

f
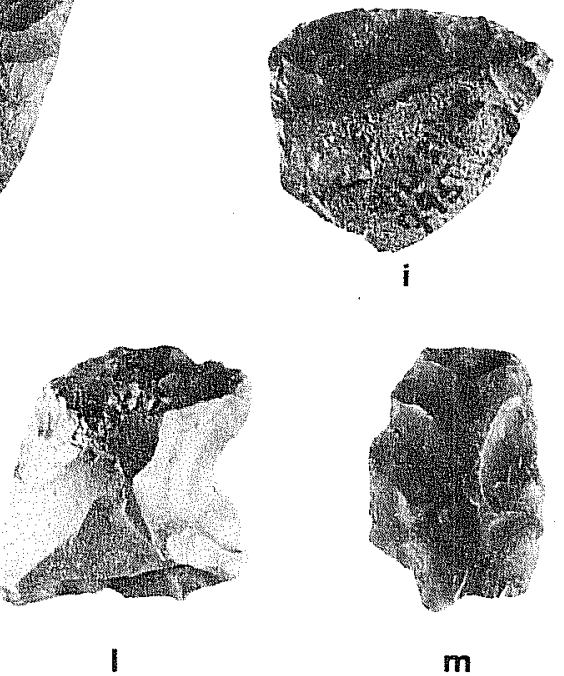
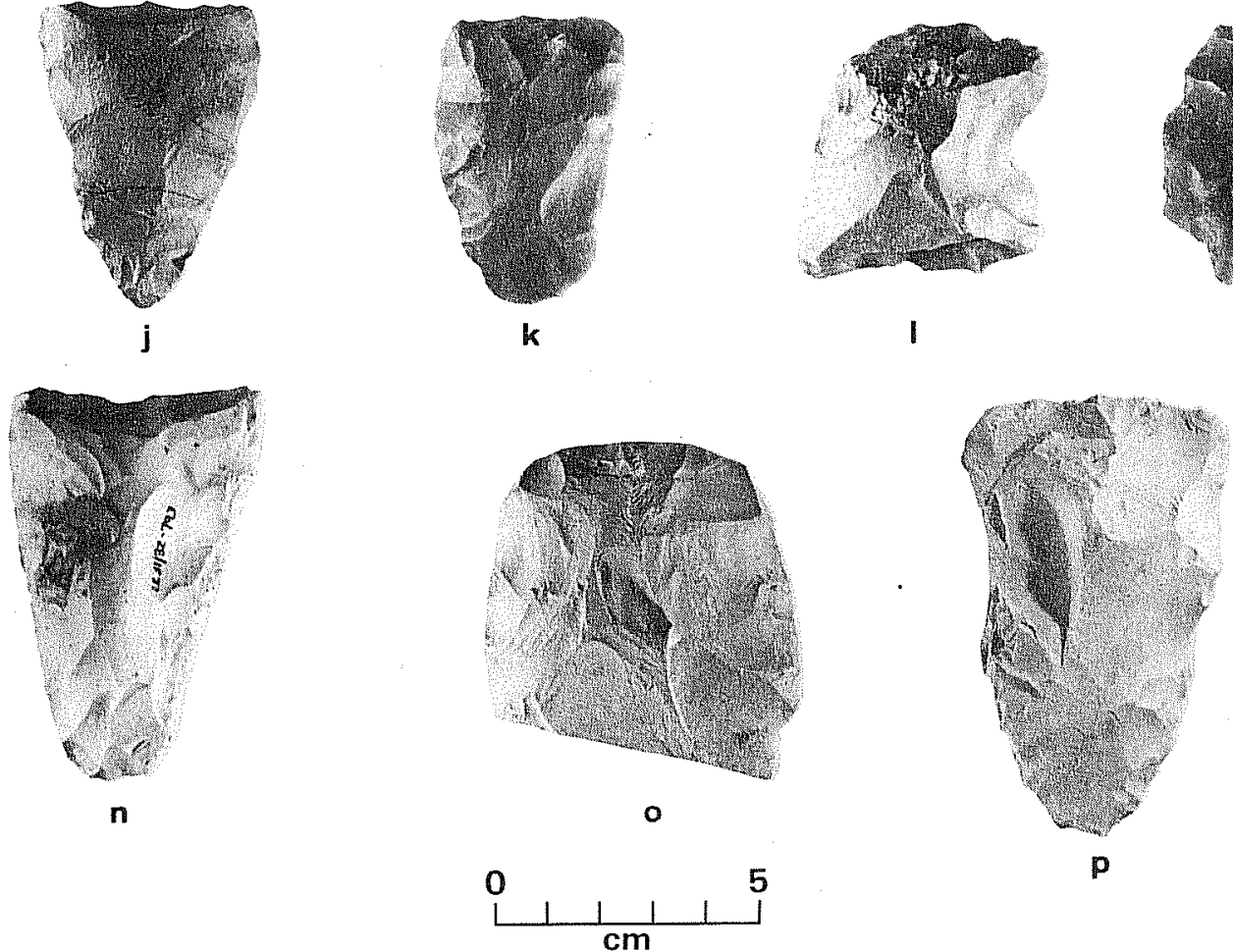
Thin Bifaces (continued)

Group 10. Lateral and Medial Fragments (13 specimens)

Unclassifiable fragments of lateral and medial biface portions are lumped in this group. Similar agents from Group 9 are presumably responsible.

Distally Beveled Bifaces and Unifaces

Unifacial and bifacial tools with beveled ends or bits are included in this class. Tool thickness was not a criteria with these tools, as the beveled end (or bit) was considered to be the critical defining factor. Published names applied to these tools include Clear Fork gouges, Guadalupe adzes, Olmos bifaces, and Nueces scrapers. Hal1 (Ha11, Black, and Graves 1982) describes the shapes as triangular/subtriangular to rectangular/subrectangular to elliptical to oval. Biconvex and plano-convex cross sections are common. Many of the specimens exhibit battering and step-fracturing at the bit edge.

Nine groups were described by Ha11, of which seven were present at 41 LK 31/32. Refer to Table 7 for provenience and metric data for distally beveled bifaces and unifaces. For more complete descriptions and a list of categories not discussed herein, please refer to Hall (ibid.).

Group 1. Large Triangular to Subtriangular (Clear Fork Gouge Type, 1 specimen)

A single specimen of this type was surface collected at 41 LK 31/32. It was triangular in shape and biconvex in cross section (Fig. 16,n). Edges were convex to subconvex, and a pronounced bit was located at the broad distal end of the biface (equals Hal1's Specimen 2 and Number 1 of Ray 1941).

$\frac{\text { Group 2. Large, Elongate, Rectangular to Subrectangular (Clear Fork Gouge }}{\text { Type, } 1 \text { specimen) }}$

The single example of a Group 2 gouge was also surface collected. It is rectangular with parallel edges and a steep bit on its proximal end (corresponds to Ha11's Form 1, Specimen 1 and Number 3 of Ray 1941).

Group 3. Short, Broad, Triangular to Subrectangular (2 specimens)

Form 2. Triangular, Proximal End Rounded (2 specimens)

Bifaces in Group 3 are generally wide, short, and well flaked. Width at the bit often equals or exceeds the total length of the tool. The outline is triangular, and both examples from 41 LK $31 / 32$ exhibit we11-defined, battered bits (Fig. $16, g, h)$. Specimens 1 and 2 were placed under Form 2 due to the slight concavity in the bit. 
TABLE 7. PROVENIENCE AND METRIC DATA FOR DISTALLY BEVELED BIFACES AND UNIFACES

UNIT LEVEL ELEVATION DIMENSIONS $(\mathrm{cm})$ WEIGHT $(\mathrm{gm})$

Group 1. Large Triangular to Subtriangular surface $7.0 \times 4.7 \times 2.3 \quad 64.3$

Group 2, Form 1. Large, Elongate, Rectangular to Subrectangular (Clear Fork gouge, Type 3 after Ray 1941).

surface

$8.3 \times 3.8 \times 1.5$

51.2

Group 3, Form 2. Short, Broad, Triangular to Subrectangular (Triangular, Proximal End Rounded)

$\begin{array}{lllllll}\text { N1059 E865 } & 9 & 97.85-97.75 & 4.3 \times 4.3 \times 1.4 & 24.0 \\ \text { N1065 E875 } & 7 & 98.05-97.95 & 4.6 \times 3.4 \times 1.4 & 32.9\end{array}$

Group 4. Smal1 Triangular to Subtriangular

$\begin{array}{lcccccc}\text { N1061 E873 } & 6 & 98.25-98.15 & 5.4 \times 3.2 \times 1.3 & 26.0 \\ \text { N950 E838 } & 3-4 & 99.90-99.50 & 5.8 \times 4.2 \times 1.2 & 28.5\end{array}$

Group 7, Form 2. Various Forms with Broad, Rounded, Low-Angle Bevels; Short, Broad, Subrectangular to Oval

N1059 E861

11

97.75-97.65

$6.2 * 5.8 \times 1.7$

Group 7, Form 4. Distal Fragments

N1083 E1 108

6

98.75-98.55

$4.7 * 4.5 \times 2.4$

surface

$5.1 * 5.3 \times 4.1$

Group 8, Form 4. Miscellaneous Forms; Broad Flat, Triangular surface

$4.4 \times 5.2 \times 1.5 \quad 31.2$ 
Distally Beveled Bifaces and Unifaces (continued)

Specimen 1, recovered in Unit $N 1059$ E865 approximately $225 \mathrm{~cm}$ below the surface, was basically unifacial with bifacial trimming on the extreme proximal tip. Specimen 2, recovered in Unit $N 1065$ E875 at $205 \mathrm{~cm}$ below the surface, was bifacial. Both gouges are within the stratigraphic range of the 2350 B.C. date, suggesting a Middle Archaic affiliation for these tools.

Form and bit battering on the gouges suggests that tools of this category are depleted versions of Group 1 or 2 gouges.

\section{Group 4. Small Triangular to Subtriangular (2 specimens)}

The two specimens (Fig. $16, j, k$ ) in this group correspond to Hall's Specimens 6 and 7. Characteristics of this group include small size, straight to convex bit edges, thinness, and fine flaking. Cross sections range from plano-convex to biconvex.

Specimen 1, recovered from Unit N950 E838, was unifacially flaked and showed evidence of heat treating. It was recovered $30-50 \mathrm{~cm}$ below the surface (level 4). Specimen 2, recovered $175 \mathrm{~cm}$ below the surface, in Unit 11061 E873 (1evel 6) was less well formed but exhibited bifacial flaking and a prominent distal bit. Neither tool was directly associated with a radiocarbon assay.

Group 7. Various Forms with Broad, Rounded, Low-Angle Bevels ( 3 specimens)

Group 7 tools are highly variable in form but have an edge Hall describes as "shove1-shaped." The bit is not steep, and battering or use wear is not evident. Four tool forms were defined by Hall of which 3 are in evidence at $41 \mathrm{LK} 31 / 32$.

Group 7 tools are felt to be unfinished gouge-type tools, broken in manufacture or discarded for imperfection in desired form. The shovel-shaped bit is the unbattered or unresharpened form of other gouge tools described in previous groups.

Form 2. Short, Broad, Subrectangular to oval (1 specimen)

This form is described by Hall as "shorter and wider" than Form 1 specimens (Fig. 16,0). The lone example from 41 LK 31/32 (equals Hall's Specimen 3) was recovered in Unit N1059 E861 at approximate1y $235 \mathrm{~cm}$ below the surface (1evel 11). The tool shows signs of heat treatment and use or retouch along the "shoveled" distal end. 
Distally Beveled Bifaces and Unifaces (continued)

Form 4. Distal Fragments (2 specimen)

- Specimen 1 (also equating with Hall's Specimen 1) was recovered in Unit N1083 E1108, 125-145 cm below the surface (1evel 6). The distal fragment shows evidence of having also been a perforator (Fig. 16,1,m).

\section{Group 8. Miscellaneous Forms (1 specimen)}

This broad group is represented by 5 forms having a distal bevel as a common trait. Only Form 4 is represented at 41 LK $31 / 32$.

Form 4. Broad, Flat, Triangular (1 specimen)

A single specimen recovered at a depth of approximately $80 \mathrm{~cm}$ below the surface (1eve1 4) of Unit 11116 E998. It is thin, plano-convex in cross section, has a wide bit, and a general triangular outline (Fig. 16,i). Bit angle is low.

\section{Debitage Analysis}

Lithic debitage, the by-product of stone tool production, is often the most extensive evidence of prehistoric activity at a site. For this reason, it assumes a critical role in the interpretation of site function and the activities of its inhabitants. In addition to formal tools (dart points, gouges, knives etc.), lithic waste debris in the form of a flake or a chip can be used as an effective, expedient, expendable tool for a variety of functions. Furthermore, debitage from the manufacture of formal stone tools can provide clues as to what tools were made at the site, although the tools themselves were not necessarily left or recovered during excavation.

In tota1, 41 LK $31 / 32$ yielded 7611 pieces of 1ithic debitage. These could be divided as follows:

\begin{tabular}{lr} 
Category & Number \\
\cline { 2 - 2 } Primary Flakes & 79 \\
Secondary Flakes & 885 \\
Tertiary Flakes & 2037 \\
Chips & 4610
\end{tabular}

Primary flakes were those exhibiting an $80 \%$ or greater covering of cortex on their dorsal surface. Secondary flakes retained 1ess than $80 \%$ cortex on the dorsal surface, and tertiary flakes (often termed interior) were devoid of any cortex whatsoever. Chips were defined as flakes with no platform present. Flakes were initially divided into categories based on a combination of platform attributes (cortex, single facet, small or large multiple facet, or lipped platforms) and flake utilization (if any). Trimmed flakes were those 
that had been resharpened or exhibited an edge modified by flaking, whereas modified flakes designated those showing use wear on an untrimmed edge. ATl flakes were examined under low power (10X) magnification during analysis for signs of utilization.

Access to raw materials is generally easy in the area of the Choke Canyon Reservoir. Pleistocene gravel deposits contain a variety of cherts and silicified woods suitable for knapping. These gravels, however, are nodular in form and were of inconsistent quality for the aboriginal flintknapper. The result was a large percentage of primary and secondary flakes struck from natural (cortex) platforms in the initial stages of cobble reduction. Detachment of flakes in this manner would result in (a) flakes suitable for further reduction into thin bifaces or unifacial tools, and (b) cobble cores suitable for reduction as cores, or into core bifaces and thick bifaces. This process is well illustrated by Lynn, Fox, and 0'Malley (1977:100-102).

Primary flakes, however, exhibited a larger percentage of single facet platforms rather than cortex platforms:

\begin{tabular}{lc} 
Category & Percentage of Total \\
\cline { 2 - 2 } Cortex Platforms & 28 \\
Single Facet Platform & 56 \\
"Other" Platform & 16.
\end{tabular}

This indicated a cautious approach to decortication with reliance on a single platform, probably prepared by grinding or striking perpendicularly on an existing flake scar. Had the cobbles been tested at the quarry source, we might expect a smalier proportion of cortex platform flakes appearing at 41 LK $31 / 32$ since these flakes would have been discarded prior to transporting material to the site. Additionally, only a single trimmed cortex flake was recovered, tending to support an inference of absence or nonuse of cortical flakes.

Direct evidence of the lack of utilization of primary flakes occurred in Feature 16, an intact core-reduction area occurring in Units N1061 E873 and N1063 E873. This feature is stratigraphically contemporaneous with Feature 6 , radiocarbon dated at 2360-2340 B.C. Five chert cobbles had been reduced in one spot, and none of the resulting flakes had been taken away. Two of the larger cores had been struck less than three times, removing large, irregular cortexcovered primary flakes. Impurities seemed to have been present in each cobble and had obviously hampered reduction attempts. One smaller, egg-shaped cobble had been split on either side of a thick, disc-shaped central portion, possibly in pursuit of a secondary flake suitable for bifacial reduction. Throughout the sequence of reduction, natural platform and cortex platforms were utilized, although no evidence of platform preparation was found. None of the more than 100 flakes or debris had been removed after detachment, suggesting that the debitage and remaining unused portions of the cores were unsuitable for the fl intknapper's intended purpose.

Feature 16 is unusual in that the cobbles were transported to the site prior to removal of some or all of the cortex. From additional site evidence, it is not unusual that the primary flakes remained unused. That Feature 16 was an 
isolated incident is highlighted by the fact that only a single hammerstone was recovered in excavations at 41 LK 31/32--with Feature 16. Thirty cores were recovered during excavation, many exhausted or knapped to a point where effort had far exceeded raw material return. The general absence of primary flakes on the site indicates that cores were prepared elsewhere (generally, in light of Feature 16) and utilized as necessary in site activities.

Primary flakes were scarce throughout the units. Numerically, they rarely occur as more than five in any $2-\mathrm{m}^{2}$ level. Including chips with $100 \%$ cortex, the number rises to. only 14 in level 7 (98.05-97.95 cm depth) in Unit N1065 E873. Inclusive of chips, primary flakes never exceeded $1.1 \%$ of the total debitage inventory; exclusive of chips they never exceeded $4 \%$. For the entire site, exclusive of chips, primary flakes accounted for $2.7 \%$ of the total debitage count.

Secondary flakes accounted for $29 \%$ of the total site debitage count ( 887 flakes). They fell into the following platform categories:

\begin{tabular}{lc} 
Category & Percentage of Total \\
\cline { 2 - 2 } Cortex Platform & 41 \\
Single Facet Platform & 33 \\
Sma11 and Large Multiple & 15 \\
Facet Platform & 11 \\
Lipped Platform &
\end{tabular}

Since secondary flakes represent an intermediate stage of lithic reduction, it is not unusual to find seemingly discrepant traits such as cortex platforms and lipped platforms in the same list.

The high percentage of cortex platform flakes is expected with the production of core bifaces or thick bifaces from irregular nodules. Thin bifaces require control over the surface flakes used to reduce it thickness. Thinning flakes, then, would be expected to have ground platforms, shaped and occasionally chipped to isolate a striking platform for maximum control. Multiple facet and 1 ipped platform flakes represent this type and together account for $25.6 \%$ of the secondary platform total. Single facet and cortex platform flakes usually indicate direct, hard-hammer percussion, normally used to flake cores or core bifaces. The ground platforms usually are felt to indicate soft hammer (such as antler or bone) percussion.

The secondary stage of 1 ithic reduction usually "roughs out" the tool form, removing remaining cortex and shaping a basic form to be refined by tertiary flaking. Therefore, if tools were actually shaped and finished at $41 \mathrm{LK} 31 / 32$, it could be expected that concentrations of secondary flakes, as well as tertiary flakes, would indicate discrete areas of lithic manufacture. Broken and discarded tools would be expected to occur with these concentrations.

Unit N1083 El108 offers an excellent example. Leve1s 5-10 yielded between 1540 secondary flakes per level. The concentration was as follows (exclusive of chip count for secondaries): 


\begin{tabular}{|c|c|c|c|}
\hline Level & Elevation & No. Secondary Flakes & Bifaces and Cores \\
\hline $\begin{array}{r}5 \\
6 \\
7 \\
8 \\
9 \\
10\end{array}$ & $\begin{array}{l}98.95-98.75 \mathrm{~m} \\
98.75-98.55 \mathrm{~m} \\
98.55-98.35 \mathrm{~m} \\
98.35-98.15 \mathrm{~m} \\
98.15-97.95 \mathrm{~m} \\
97.95-97.75 \mathrm{~m}\end{array}$ & $\begin{array}{l}15 \\
40 \\
38 \\
20 \\
40 \\
30\end{array}$ & $\begin{array}{l}1 \text { biface } \\
7 \text { bifaces, } 2 \text { cores } \\
2 \text { bifaces, } 5 \text { cores } \\
4 \text { bjfaces } \\
3 \text { cores } \\
2 \text { cores }\end{array}$ \\
\hline
\end{tabular}

Feature 17 yielded 31 secondary flakes in the level that contained two large broken bifaces and one complete biface.

Large numbers of secondary flakes were also associated with bifaces (and possibly with Feature 18) in Units N1065 E873 and N1065 E875, levels 7 and 8 (depth 98.05-97.95 m). In Unit N1059 E861, level 11 (depth 97.95-97.85 m) exhibits a high ratio of secondary to tertiary flakes as well as a biface fragment. It is possibly associated with Feature 15.

High ratios of secondary to tertiary flakes are not necessarily associated with tools, tool fragments, or features. They merely offer material evidence by association of a subsistence activity related to site occupation.

Thirty secondary flakes had evidence of wear or trimming. This represents $17.8 \%$ of the utilized flakes occurring at 41 LK $31 / 32$.

Tertiary flakes are usually considered thinning flakes as they represent the final stage of manufacture of any stone tool. Generally, they are smaller and more numerous than both primary and secondary flakes. 41 LK 31/32 yielded 2088 tertiary flakes in the following categories:

\begin{tabular}{lc} 
Category & Percentage of Total \\
\cline { 2 - 2 } Single Facet & 40 \\
Small and Large & 35 \\
Multiple Facet & 25 \\
Lipped &
\end{tabular}

Multifaceted and lipped tertiary flakes, like the secondary flakes, are assumed to be the product of edge preparation and platform grinding. Concentrations of tertiary flakes are also felt to represent areas of discrete tool manufacture.

Unit N1057 E861, leve1 11 (97.85-97.75 m) contained 259 smal1 thinning flakes although no tools. A large number of secondary flakes (55) were recovered in the same level, indicating an area once subject to a brief episode of intense tool finishing. Unit $N 1083$ El108 represents a similar situation in levels 510.

Tertiary flakes comprised $28.4 \%$ of the utilized flakes recovered from 41 LK $31 / 32$. Al though rough 1 y $10 \%$ more than the utilized secondary flakes recovered, it is still half of the 90 (53.2\% of total) utilized chips recovered.

Chips represented $59.5 \%$ of a 11 1ithic debitage recovered at 41 LK $31 / 32$. They were initially classified as corticate, partially corticate, or decorticate 
depending on the amount of cortex retained. As this roughiy corresponds to primary, secondary, and tertiary flakes, they were added to overal1 totals in the unit-level counts, although tallied separately.

\begin{tabular}{lc} 
Category & Percentage of Total \\
\hline Corticate & 11 \\
Partially Corticate & 22 \\
Decorticate & 67
\end{tabular}

Chips represent a variety of problems for interpretation because of their fragmentary nature and lack of platforms. The product of stress as flakes are removed from cores or bifaces, they are nonetheless a legitimate portion of a debitage assemblage.

No blades were recovered during excavation of $41 \mathrm{LK} \mathrm{31/32.} \mathrm{B1ades} \mathrm{have} \mathrm{been}$

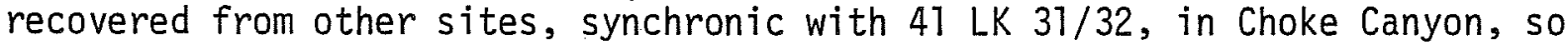
they certainly were part of the knapper's products. I am at a loss to explain their absence here.

Horizontal distribution of flake scatters, tools, and features will be discussed in Interpretations and Summary along with the Hester-Collins Model of lithic procurement on the Rio Grande Plain.

\section{Ground Stone Artifacts}

Fifteen items were included in the ground stone tool category at 41 LK 31/32. The tool category can be defined as: (1) sandstone fragments on which one or more smoothed, even surfaces are visible, and/or (2) sandstone fragments which show shape alteration such as unusually straightened edges and rounded or squared corners.

The weathered and fragmentary condition of the sandstone recovered from the site makes artifact identification difficult. It is apparent that the original surfaces (presumably the result of grinding tasks such as food processing) have deteriorated into smaller fragments. Fire may have been a primary factor contributing to the fragmentary nature of this group; at least $75 \%$ of the specimens exhibit heat discoloration. Provenience and metric data are given for the ground stone artifacts in Table 8. The sandstone artifacts are described, by lot number, as follows:

\section{Lot 21 ( 3 specimens)}

Specimen 1. This rectangular specimen has one smoothed surface which is concave in cross section. The sandstone is of moderate density.

Specimen 2. This triangular item has one very flat surface $(4.5 \times 3.5 \mathrm{~cm})$. The sandstone is of moderate to loose consolidation. 
TABLE 8. PROVENIENCE AND METRIC DATA FOR GROUND STONE ARTIFACTS†

\begin{tabular}{|c|c|c|c|c|c|c|c|}
\hline UNIT & LEVEL & ELEVATION & $\begin{array}{c}\text { NO. OF } \\
\text { SPECIMENS }\end{array}$ & LENGTH & WIDTH & THICKNESS & WEIGHT \\
\hline \multirow[t]{3}{*}{ N1056 E863 } & 6 & $98.23-98.15$ & 3 & 11.0 & 6.5 & 3.0 & $215.0 *$ \\
\hline & & & & $5.0^{*}$ & $3.0 *$ & 2.5 & $19.0 *$ \\
\hline & & & & $3.5^{*}$ & $3.0^{*}$ & 2.5 & $19.0^{*}$ \\
\hline N1059 E865 & 9 & $97.85-97.75$ & 1 & $4.0^{*}$ & $3.0^{*}$ & 1.5 & $15.0 *$ \\
\hline \multirow[t]{3}{*}{ N1061 E873 } & 8 & $98.00-97.75$ & 3 & $4.5^{*}$ & $4.0 *$ & $3.0^{*}$ & $77.0^{*}$ \\
\hline & & & & $6.5^{*}$ & $5.0 *$ & $4.0 *$ & $157.0 *$ \\
\hline & & & & $5.5^{*}$ & $4.5^{*}$ & $3.0^{*}$ & $84.0^{*}$ \\
\hline N1065 E875 & 11 & $97.65-97.55$ & 1 & $6.0 *$ & $4.0 *$ & 2.0 & $61.0^{*}$ \\
\hline surface & & & 1 & $8.5^{*}$ & $4.0 *$ & 2.0 & $52.5^{*}$ \\
\hline
\end{tabular}


Specimen 3. This roughly, triangular specimen may originally have fit with Specimen 2. It has one small flat surface $\left(2 \mathrm{~cm}^{2}\right)$. The sandstone consolidation is moderate to loose.

Lot 440 ( 1 specimen)

This triangular specimen has one smal1 ground surface $(1.5 \times 2.5 \mathrm{~cm})$. It is flat in cross section. The specimen was broken during recovery. The sandstone consolidation is loose.

\section{Lot 491A (3 specimens)}

Specimen 1. This roughly square item has two flat surfaces at right angles, joined by a straight, rounded edge $\left(4 \mathrm{~cm}^{2}\right.$ and $4.0 \times 2.0 \mathrm{~cm}$, respectively). The sandstone consolidation is moderate to hard.

Specimen 2. This rectangular specimen has four flattened surfaces $(6 \times 4,6 \times 3,3 \times 2.5$, and $6 \times 2.5 \mathrm{~cm})$ which undulate slightly. The remaining two surfaces are fractured and uneven. The consolidation of the sandstone is hard.

Specimen 3. This roughty square specimen has two surfaces, one slightly convex $(4 \times 2 \mathrm{~cm})$, one flat and undulating $(4 \times 2 \mathrm{~cm})$. Sandstone consolidation is moderate to hard.

Specimens 1,2 , and 3 seem to be fragments of a larger, original artifact. The original artifact was at least $5 \mathrm{~cm}$ thick.

\section{Lot 644 (1 specimen)}

The specimen has two surfaces joined by a rounded edge. Both surfaces are flat in cross section $(5.5 \times 3 \mathrm{~cm}$ and $4.0 \times 3.5 \mathrm{~cm})$. The specimen is subrectangular in shape, and sandstone is moderate to hard in consolidation.

\section{Lot 784 (1 specimen)}

The triangular specimen has one large flat grinding surface that covers one side of the artifact $(8.5 \times 4 \mathrm{~cm})$. The sandstone consolidation is very hard.

\section{FAUNAL ANALYSIS}

The prehistoric component of 41 LK $31 / 32$ produced a small sample of fauna 1 remains. Bones were equally absent in the fine-screened sample as in the soil processed through the 1/4-inch hardware mesh. In a11, about three dozen fragments were collected across the site, only six of which were suitable for identification. All identification was done by Harold Woolridge and is summarized in Table 9. All of the animals identified are still present in the area and do not reflect any climatic shift or concentration on a single habitat. 
TABLE 9. VERTEBRATE FAUNA*

\begin{tabular}{llll} 
UNIT LEVEL/ZONE & SPECIES & COMMON NAME ELEMENT \\
\hline
\end{tabular}

$\begin{array}{lllll}\text { N1083 E1108 } & \text { Leve1 } 8 & \text { Aplodinotus grunniens } & \text { Freshwater drum fish Otolith } \\ \text { N1094 E999 } & \text { Leve1 1 } & \text { Zenaida macroura } & \text { Mourning dove } & \text { Humerus } \\ \text { N1094 E998 } & \text { Leve1 1 } & \text { Charadrius vociferus } & \text { Killdeer } & \text { Humerus } \\ \text { N1057 E865 } & \text { Zone 2 } & \text { Aplodinotus grunniens } & \text { Freshwater drum fish Otoliths (2) } \\ \text { N1064 E876 } & \text { Zone 2 } & \text { Sylvilagus sp. } & \text { Cottontail rabbit } & \text { Phalanx } \\ \text { N1057 E861 } & \text { Leve1 16 } & \text { Unidentifiable } & \text { Turtle } & \text { Carapace } \\ \text { N1056 E863 } & \text { Leve1 9 } & \text { Unidentifiable } & \text { Unidentifiable } & \text { Artiodacty1 } \\ & & & & \text { phalanx } \\ & & & \text { fragment }\end{array}$

*Identifications by HaroTd $G$. Woolridge, Austin.

Bone preservation was generaliy poor. Whereas soil conditions (as determined by the Texas Agricultural Extension Service, Texas A\&M University) were slightly alkaline ( $\mathrm{pH}$ ranged from 8.2-9.0) and not necessarily destructive to bone, constant wetting and drying in the open site was no doubt injurious to the remains.

What the bones directly reveal about subsistence activities at the site is unfortunately little. The association of two freshwater drum otoliths with Feature 2 at least indicates exploitation of the riverine habitat other than freshwater mussels. Land mammals are notably absent with the exception of a cottontail phalanx in Zone 2 of Unit N1064 E876 and an unidentified artiodactyl phalanx fragment from level 9 of Unit N1056 E863. It is somewhat remarkable to find any site in central or south Texas in which identified remains of whitetail deer are completely absent.

Two bird humeri were recovered on the site, but not in association with cultural materials. A single killdeer and mourning dove are represented and are likely to have occurred in level 1 of Unit N1094 E998 through natural agents.

Overall, the absence of bones cannot be adequately explained by the effects of soil and weathering. For instance, features were generally in a.condition that indicated little, if any, exposure to weathering or erosion after use. Particularly in the cases of Features 2, 6, 11, and 16, rapid accumulation of sediments with little movement of associated mussel and snail shells appears to have been the rule. Coupled with a very small number of projectile points recovered (only two stratigraphically below Zone 4), the evidence suggests subsistence was based on the gathering of wild plant foods. Supplemental nutrition was available from freshwater mussels and land snails as the site was not used for procuring locally available fish, reptiles, and mammals.

The inclusion of freshwater drum otoliths in Zone 2 as well as Sylvilagus (cottontail rabbit) suggests that occupation during this period (4710 B.C.) was based on seasonally available resources of which wild game was a part. Later absence of bone suggests a specialization toward procuring and processing plant foods. 
Though seasonal subsistence patterns may help to explain the rarity of faunal remains, at least one alternative should be considered. Animal and fish bones could have been mashed for marrow or for "bone butter" or ground into flour (Newcomb 1961:41; Ruecking 1953:487). Tiny bits of crushed bone could have been mixed, and eaten, with gruel, soups, and mush in much the same ways as mentioned for the Cahuilla peoples of Southern California (Hester 1972:285; Bean 1972).

\section{SNAIL SHELL ANALYSIS}

All whole snail shells found in matrix excavated during the course of prehistoric excavations at 41 LK $31 / 32$ were collected. She 11 fragments, primarily of Rabdotus sp., were not saved. Terrestrial gastropods such as Rabdotus, Polygrya, Practicolella, Helicina, and Succinea were common. An aquatic species, Helisoma, occurs occasionally in the collection. Debris concentrates resulting from water washing through flyscreen yielded shells representing the above group as well as Helicodiscus, Carychium, Gastrocopta, Lymnaea, Pupisoma, Pupoides, and Microceramus. A count of whole Rabdotus shells recovered from the site are presented on a unit and level basis in Appendix II. Data concerning provenience and frequency of other snail species are on file at the Center for Archaeological Research, The University of Texas at San Antonio.

\section{MUSSEL SHELL ANALYSIS}

Fragmentary and whole remains of freshwater molluscs were commonly encountered during excavations of $41 \mathrm{LK} 31 / 32$. The context in which they occurred varied depending on the area of the site being excavated. Unit N1083 E1108, the easternmost area of the site to be sampled, yielded mussel shel1 scattered throughout several levels (particularly levels 4, 5, 9, and 10). Within this unit, shells were not associated with features or concentrated in easily defined discrete clusters. Condition of the shells was generally poor as a result of the tough matrix in which they were encased. Similar shell conditions and distributions were also the rule with Units N1116 E998 and N1097 E998.

The western edge of the site, which was extensively excavated, also yielded mussel debris, although in a somewhat different context. In units tested in the area scraped of overburden, mussel shells were normally found in association with features. Zone 2, Features 1, 2, 10, and 17 had she11s intermixed with charcoal, ashy soil, and burned rocks. Features 6,11 , and 16 showed discrete associated clusters. Whole and fragmentary shells did occur sporadically throughout levels, but not to the extent found on the eastern portion of the site. Shell condition was again quite friable in the tough matrix.

Collection of the mussel shells included plotting and drawing those associated with features or occurring in discrete clusters. She1ls encountered as part of the level fill were not plotted. Attempts were made to salvage as many complete shells as possible, even though soil conditions made this a rare occurrence. Fragility of the shells also made recovery efforts at the water screens difficult, as the shells tended to break up when washed. 
Identification of shells was undertaken by Dr. Harold Murray of Trinity University, San Antonio. Umbos of the shells and what few complete ones were recovered were submitted for identification. The analys is conducted by Murray (1982) is based on only $15 \%$ of the sample which was identifiable. The results are summarized in Table 10. Murray (personal communication) notes that al1 four species positively identified still occur in the Frio River and its drainages. Additionally, all are collectable in shallow water.

TABLE 10. IDENTIFIED MUSSELS FROM 41 LK 31/32*

Species Identified
Cyrtonais tampicoensis
Lampsilis anodontoides
Carunculina parva
Amblema plicata

Species Not Identified

Lampsilis sp.

Quadrula sp.

Amblema sp.

Leptodea sp.
Identification Unconfirmed

Truncilla sp. Elliptio sp.

\footnotetext{
* Listed in descending order of abundance.
}

Within the collection, Dr. Murray (ibid.) notes several items of interest. For example, the species Carunculina parva was the most abundant in the collection, although it is the smallest unionid found in the United States (averaging 2.5$5 \mathrm{~cm}$ in length). Contrasting that is the occurrence of only five Amblema plicata in the collection, a larger and heavier species that is still common in the Frio River. Quadrula sp. occurs in very low numbers, and Anodonta sp. is entirely absent. Murray suggests that if mussels were collected randomly, the low numbers of Quadrula and Amblema plus the absence of Anodonta would not be the case.

Unfortunately, the smal1 percentage of mussels identified makes interpretation dubious. Environmental change influencing which species were present in the drainage through time would be convenient, but is doubtful because all species present occur, even in very small numbers, throughout the chronological sequence of the site. With the present sample, ambiguities from a random collection might well be accounted for by forever-lost taste preferences peculiar to the seasonal inhabitants of 41 LK $31 / 32$.

Protein supplied by mussels is slight in relation to fish, reptiles, or mammals. Studies by Parmalee and K1 ippel (1974:421-434), Wing and Brown (1979:135-142), and Cook (1946) indicate that a considerable number of mussels are necessary to supply daily protein for a single human. Mussels, al though abundant in numbers, supplied only a portion of the actual diet, supplementing other sources of nourishment.

\section{INTERPRETATIONS AND SUMMARY OF PREHISTORIC OCCUPATION AT 41 LK $31 / 32$}

\section{Interpretations}

Excavations at 41 LK $31 / 32$ have provided a variety of new information to help provide a better understanding of the prehistory of south Texas. This final section attempts to incorporate the analysis of the raw data into certain 
areas of the research design for the Choke Canyon investigations. In particular, five problems are addressed in this section; although treated separately, they all nonetheless pertain to prehistoric people, closely dependent on (if not at the mercy of) their environment. They are:

1. Horizontal Distributions: organization of subsistence activities at the site;

2. Subsistence Strategies: food remains at the site;

3. Settlement Patterns: seasonal movements of the aboriginal groups;

4. Hester-Collins Model: lithic technology on the Rio Grande Plain; its implications and applications to the remains from 41 LK $31 / 32$;

5. Chronological Implications: the contributions of the data from 47 LK $37 / 32$ toward the development of a chronological scheme for southern Texas.

Some of the following interpretations may indeed not stand the test of time, and they are not necessarily meant to. Open debate of pressing questions in prehistoric south Texas is essential and will, I am hopeful, be stimulated by some of the following statements. Furthermore, findings at $41 \mathrm{LK} 31 / 32$ pose questions which should be addressed during future investigations in the region.

By the same token, the following interpretations are based on sound evidence recovered during the summer of 1978 and analyzed and reinterpreted dozens of times since. It is hoped that critical evaluation of these data continue from here and be supported or rejected by work aimed at the same objectives.

\section{Horizontal Distributions}

Artifacts, features, and debitage were plotted over broad, horizontal areas to look for patterns of intersite organization of labor division. This was accomplished during analysis by attempting to adjust horizontal strata, recognizable in profile only, to the rigid $10 \mathrm{~cm}$ level system employed.

It became evident during excavation and later in reviewing notes, that the soil strata generally dipped to the west (towards the Frio River) in the scraped area. While rising slightly in elevation to the east, the strata also became thinner, especially Zone 2. Recovery of features and artifacts was considerably higher in the western units of the scraped area where Zone 2 was thickest.

Features $1,2,3,10$, and 17 were associated with occupation during the formation of Zone 2. This rather sudden appearance of cultural material (Zone 1, 10-20 cm deeper, is sterile) is marked by an intense activity where cores were reduced, bifaces produced, and hearths actively maintained. Scatters of freshwater mussel shells, Rabdotus snail, and two freshwater drum fish oto1 iths, indicate the kinds of foodstuffs that may have dominated the diet, although bone fragments in Feature 3 suggest hunting was also practiced. Tools, particularly the cores and three concave-based broken bifaces recovered from Feature 17, are intermixed with flaking debitage, mussel and snail shel1, 
and burned rocks. Broad ash/charcoal stains, scattered burned rocks, and shallow outlines generally define the features, suggesting a lack of formal preparation.

The only formal tools associated with the five features were three broken, concave-based bifaces. These evoke interest in that two exhibit bases we11. prepared prior to finishing (and breaking). All were associated with Feature 17 and a considerable amount of associated flaking debris and shell refuse, as well as some edge worn flakes and the aforementioned cores.

Multiple functions were performed in a small area with no obvious task differentiation. Feature 14 exhibits a similar association of a stained pit, ash, scattered rocks, and mussel and snail shells in a relatively confined but poorly delineated area. However, a dart point was found with the feature, and a utilized flake and a preform were associated $2 \mathrm{~m}$ north of the feature. Feature 15, stratigraphically just above Feature 14, is associated with Feature 9 and exhibits a similar association with a biface, core, and dart point between the two (Features 9 and 15). Very little flaking debris occurs with these three features or in these levels in any units in the scraped area.

Task separation appears to be evidenced in the cultural remains found at elevation 97.85-97.75 below datum (contact of Zone 4 and Zone 5). At this level, 594 tertiary flakes were recovered in Unit N1057 E861, a gouge, 2 bifaces, a core, and a utilized flake in Unit N1059 E865, and a broken biface from Feature 20. A similar situation is encountered at elevation 98.05-97.95 where Feature 18 is separated $2 \mathrm{~m}$ from 200 thinning flakes in Unit N1065 E873, and $4 \mathrm{~m}$ from Unit N1065 E875 in which a gouge, mussel shel1s, and 80 thinning flakes were found.

Separation of features and task areas appears to reach an extreme at 98.7598.15 where Features 6 and 11 occur. Neither feature was associated with any tools, debitage, or mussel shell concentrations. Both occurred in the western portion of the scraped area. The eastern part of the scraped area was void of features, but contained at least one utilized flake in every $2 \mathrm{~m}^{2}$ unit. Unit N1061 E873, in fact, contained a clear Fork gouge, one core, and a grinding stone. Feature 16 was originally felt to be contemporary with Feature 6 and Feature 11, but now appears to occur 10-20 cm above Features 6 and 11 , associated only with a utilized flake in Unit N1065 E873, and a concentration of mussel shells in Unit N1065 E873.

Past Feature 16, the upper $1.5 \mathrm{~m}$ of sediment generally lack large features and concentrations of debitage. This is possibly related to an increase in sedimentation after 3970 B.P. (Feature 6), destroying or altering a preferred habitat.

Surface finds of dart points on the western edge of the scraped area possibly indicated renewed Late Archaic use of the area in transient hunting. Extremely dense concentrations of chipping debitage in levels 2 and 3 of Unit N950. E838 may also indicate heavy utilization of locally available cherts at this same time. 
Units N1094 E998, N1116 E998, and N1083 E1108 were omitted from discussion due to the fact they were each $2 \mathrm{~m}^{2}$ in size. While their excavation provided proof of subsurface site continuity, information obtained from them is limited in terms of material evidence of site organization. However, chipping debris recovered from Unit $N 1083$ E1708 indicate that considerable stone tool work was undertaken in the area at a time (stratigraphically) equivalent to a time shortly preceding and following Feature 6's $3970 \pm 160$ B.P. radiocarbon date.

\section{Subsistence Strategies}

In the section on horizontal distributions, associations between features, tools, and debitage were stressed. These, along with mussel shells, snail shells, and bone fragments provide the direct and indirect evidence of what, and how, the seasonal occupants ate.

Ethnohistoric and modern studies of hunters and gatherers (Lee and DeVore 1968; Bicchieri 1972; Lee 1979; Campbe11 and Campbe11 1981) provide us with a perspective on how food was obtained through seasonal scheduling of movements. Occupation of any single location was rarely over a few weeks duration, usually coinciding with seasonally abundant plants and/or animals.

41 LK $31 / 32$ represents, as does a large portion of prehistoric archaeology at Choke Canyon, multiple short occupations by groups (bands?) of hunters and gatherers. If one were to take the entire site synchronically, the general pattern of exploitation would differ quite 1ittle; mussels, snails, and (probably) several dozen different plant foods comprised the bulk of the diet. Game and fish were obtained whenever possible. However, certain minor variations in tools found and features recorded suggest more positive statements about the reasons for the occupation of $41 \mathrm{LK} 31 / 32$.

The general location of 41 LK 31/32, on a low terrace of the Frio River, provides excellent access to the Frio's riparian banks, its floodplain, and its aquatic resources. Short access is available to the uplands and abundant raw materials as wel1. If we accept Silberbauer's (1972:297-305) range of a G/wi catchment area as being a four mile foraging radius as typical, then the catchment area of 41 LK $31 / 32$ stretches to the Nueces River on the southeast and the Atascosa River on the east. Vast stretches of prickly pear-laden uplands extend to the north and northwest. In summary, then, three rivers, three riparian environments, large floodplains, and a considerable area of uplands lie within a day's walk of 41 LK 31/32. Obviously, such an optimal location helped contribute to the repeated occupation of the site from Early Archaic times on.

Evidence from Features $1,2,3,10$, and 17 lends credence to the broad spectrum approach to exploitation. Remains of turtie, fish, mussels, and snails suggest a heavy dependence on aquatic resources at $4710 \pm 80 \mathrm{~B}$.P. Feature 14, later in time, exhibited a dart point and ashy soil stain (along with mussels and snails) suggesting hunting and plant processing along with the collecting of aquatic resources. Features 6 and 11 (Feature 6 dated at $3970 \pm 160$ B.P.) appear to represent a more radical departure in subsistence, as two large, compact hearths occupied a relatively sterile cultural stratum. Similar hearth construction does not appear again prior to or after these two features. 
It is suggested the initial occupation of 41 LK $31 / 32$ began with the development of Zone 2 and the stabilization of the Frio River in its present channel. A summer occupation is tentatively suggested based on the following observations: (1) turtles, fish, and mussels are most easily collected in the lowwater summer months; and (2) an absence of hunting tools such as dart points or end scrapers.

Bone fragments virtually disappear from the recovery above Zone 2. However, features continue to exhibit mussel and snail debris throughout the entire site occupation. Two dart points recovered with Features 9 and 14 represent the only evidence of hunting until another dart point was recovered $50 \mathrm{~cm}$ above Feature 11. Evidence of increased plant/wood utilization occurred at elevation 97.85-97.75 when the first gouge was recovered. The first grinding stone occurred at 98.25-98.15, just below the specialized Features 6 and 11 (Zone 5).

Features 6 and 11 are carefully constructed, perhaps representing the formally and intensive exploitation of a specific resource. The fact that similar construction does not appear again lends credence to the suggestion that they represent processing of a plant resource not normally available in such quantity. A climatic optimum might explain this unique (in the sense of the overall site assemblage) occurrence.

In summary then, subsistence at $4710 \pm 80$ B.P. was broadly based on aquatic resources. For reasons already stated, it is felt to represent a summer portion of a seasonal round. As the floodplain stabilized, occupation became geared to a heavier reliance on locally available plants. Dart points associated with Features 9 and 14 provide tenuous evidence of a late summer/early fall occupation, hunting deer and harvesting riparian nuts and seeds. The disappearance of dart points entirely after Features 9 and 14 suggests a heavier orientation towards plants, as does the appearance of the gouge and grinding stone. Summer would again be the optimal season for this, combining ripe seeds with easily collected mussels. Features 6 and 11, dated at $3970 \pm 160$ B.P., are felt to be special purpose features for processing quantities of a locally abundant plant resource. By this time period, all evidence of activities other than plant and mussel collecting have disappeared. Basically, the subsistence base appears to have progressively narrowed in diversity while possibly expanding in abundance of plant species exploited. Seasonal evidence for Features 6 and 11 is scant, though late summer would be a guess, especially if the hearths were interpreted as large-scale processing of prickly pear tunas which ripen at that time.

As evidence generally points toward a summer or fall residence, where were the inhabitants the remainder of the year? Campbel1 and Campbel1 (1981) noted that the Spanish accounts of the Mariames had them moving between the Nueces and Guadalupe Rivers, exploiting the riparian and surrounding environs of each river in a bilobate pattern.

Formal tools would provide some help in this question. Unfortunately, 41 LK $31 / 32$ is woefully lacking in these. The two excavated dart points (Lange and Travis-neither fit into a convenient pigeon hole) are reminiscent of central Texas. Upper excavation levels revealed a single Tortugas point, in addition to two broken bases. Tortugas points were also collected from the 
surface. Morhiss points suggest contact with the central coastal area as does a fragment of marine shell collected from the surface.

Based on this admittedly flimsy evidence, I propose the following seasonal round: in the Early Archaic a low population density began an increasingly extensive summer use of the Frio/Nueces Rivers area in search of riparian foods and prickly pear. Groups were small and possibly moved from the Balcones Escarpment to the coast utilizing a strategy of broad exploitation of all available resources. By the time Features 8 and 20 appear, sometime between 4710 B.P. and 3970 B.P., discrete utilization areas appear, along with gouges which represent wood-working tools. This suggests possibly larger groups functioning at a higher level of organization to more effectively exploit the floral potential of the area. Central Texas point types located stratigraphically below Features 8 and 20 suggest an affinity with that area. Features 6 and 11 continue to argue for complex, large scale organization in local exploitation. Sometime after 3790 B.P., Morhiss and Tortugas points appear and evidence discrete work areas and we11-prepared features disappear. I suggest that population pressure increased during the Archaic, necessitating a more restricted seasonal round, one geared to more efficient exploitation of plants in the 41 LK $31 / 32$ vicinity. By 3970 B.P., bands were coalescing to exploit volumes of an abundant plant resource, probably prickly pear. Settlement rounds may have been divided into those radiating from the Balcones Fault region and those radiating from the coast into the Choke Canyon region. Campbel1 and Campbe11's (1981) bilobate territories may well have developed by the Late Archaic with continuing population pressures making linear control of riparian environments inefficient, if not impossible.

Hester-Collins Model

Hester (1975) has outlined a scheme of lithic procurement and production on the Rio Grande Plain, termed the Hester-Collins Model by Thoms, Montgomery, and Portnoy (1981). Basically it entails three phases:

Phase I. Cobble testing by removal of one or more primary flakes to judge cobble quality;

Phase II. Initial reduction and basic tool shaping by further removal of primary and secondary flakes;

Phase III. Tool finishing with tertiary flakes being the main evidence.

Phases I and II are thought to occur at terrace sites with gravel exposures and quarry sources, whereas Phase III occurs after transport of modified materials to a large floodplain base camp.

Evidence from 41 LK $31 / 32$ generally supports the mode1. Primary flakes were extremely rare on the site and, with the exception of Feature 16, did not occur in discrete areas of lithic production. Feature 17 gave evidence of broken tools, discarded due to manufacturing failures whereas discrete areas 
in Units N1057 E861 (elevation 97.85-97.75) and N1065 E873 (elevation 98.0597.75) definitely indicate tool finishing activities. Exhausted cores are quite common, as predicted, particularly in Zone 2 between Features 1, 3, 10, and 17 and in Unit N1083 E1108, Feature 13, which was (roughly) associated with 7 cores.

Feature 16, in which cores were obviously transported to the site and tested, is only problematical in its deviation from an ideal model. In an area as rich in lithic resources as the Choke Canyon area, casual procurement is to be expected and should not alter the general observation that 41 LK $31 / 32$ yielded Tithics as predicted.

Differentiation in the core-tool and core-flake industries were difficult to discern. Finished tools are often indistinguishable as to their origin (as a flake or core). Cobble size and shape most probably dictated the actual difference, although selection for raw material suitable for a thick biface might well differ from that selected for a thin biface or dart point.

\section{Chronological Implications}

One of the original goals set forth in the research strategy of the archaeological investigations at Choke Canyon was to gather data permitting clarification and elaboration of the prehistoric cultural chronology for southern Texas. Initially, the substantial depth below surface of the cultural remains observed at 41 LK $31 / 32$ suggested that they might be the oldest subsurface remains to be found at Choke Canyon. Subsequent assay of carbon samples recovered during testing operations on the site verified this speculation. Radiocarbon assay of samples from cultural features encountered in slightly over a meter of deposit at the bottom of the site revealed that the deposit, and corresponding human debris, accumulated over approximately 1000 years of time was between 3380-3350 B.C. (TX-2920 and TX-2921) and 2360 2340 B.C. (TX-2922). Dates presented are corrected according to MASCA calibrations (see Table 2). Thus, the deepest components contained in deposits at 41 LK $31 / 32$ are important as the only definitely established subsurface examples of Early and Middle Archaic activity at Choke Canyon.

As Early and Middle Archaic activities occurred at 41 LK 31/32, rates of alluvial deposition and soil development were such that remnants of successive periods of activity on the site were stratigraphically distinct, especially the surfaces of the features yielding the three radiocarbon assays (Features 1 and 3 in Zone 2 and Feature 6 over a meter above). This stratigraphic situation, coupled with available radiocarbon assays, renders the assemblage of data and debris from the Early and Middle Archaic horizons valuable as a comparative tool.

Although chipped stone tools believed to have potential as diagnostic time indicators were not recovered in great numbers from Early and Middle Archaic

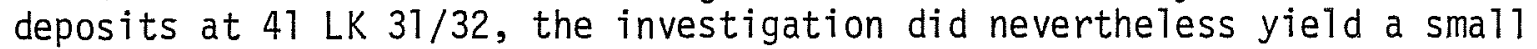
assemblage of tools which should ultimately prove useful in recognizing coeval assemblages at Choke Canyon and elsewhere in south Texas. Specimens found in Early Archaic context (Zone 2) are limited to three unstemmed, thin bifaces (all fragmentary) having triangular outlines and concave bases (Fig. 15,q,t,u). 
Most of the potentially diagnostic specimens were recovered from deposits roughly midway between the surfaces dated by radiocarbon assay. That is, between $3380-$ 3350 B.C. and 2360-2340 B.C. Among these specimens are two stemmed thin bifaces (Fig. 15,a,b), four unstemmed thin bifaces (Fig. 15, m, n, x,y), and three distally beveled tools (Fig. 16,g,h,o). The single specimen in clear Middle Archaic (Zone 5) context is a distally beveled tool (Fig. 16,k).

Upper, less extensively investigated deposits at 41 LK $31 / 32$ contained cultural debris attributed to Late Archaic activity on the site. Designation of these remains as Late Archaic is based on their stratigraphic position relative to deeper, radiocarbon-dated deposits and on the absence of recognized Late Prehistoric diagnostics (such as arrow points and aboriginal pottery) from the general debris assemblage. The suggested Late Archaic affiliation for debris occurring in the upper meter of deposit at 41 LK $31 / 32$ is not substantiated by radiocarbon dates or clearly recognized time diagnostic artifacts. Potential time diagnostic forms found in the upper meter of deposit on the site include two unstemmed thin bifaces (Fig. 15,j,aa) and one distally beveled tool (Fig. 16,j).

Early historic aboriginal activity is possibly represented at 41 LK $31 / 32$ by a metal arrow point collected from the surface a short distance east of the site's historic component (Fig. 20, C).

\section{Summary}

Zone 2, the lower occupation of 41 LK 31/32, exhibits several major differences from the Zone 5 (and above) upper occupation. Gouges and grinding stones are absent, hearths are smaller and far less compact, and finished tools are of different styles. I postulate that these differences reflect a seasonal adaptation to a dry, xeric environment. Geological studies indicated that aggradation of the Frio River may not have yet begun, resulting in scoured floodplains unsupportive of plants later exploited on a large scale. Although mesquite might have existed in limited numbers in the riparian zones, exploitation of it on a large scale was not yet economically feasible. Pollen remains from dry shelters in the Lower Pecos area (cf. Bryant and Shafer 1977) indicate that prickly pear had been exploited since wel1 prior to the 4710 B.P. lower zone date at 41 LK 31/32. Freshwater mussels, snails, fish, and turtles (one carapace fragment was identified) were being consumed, and the presence of a dart point indicates the potential of hunting. The lack of grinding implements and wood working tools such as gouges (cf. Howard 1973) strongly suggest a lack of extensive floral procurement. Secondary and tertiary lithic debris with broken tools indicates at least one specialized activity was taking place during this Middle Archaic period. By definition this occupation fits Shafer and Baxter's (1975) Model of a "Limited Function" site. A short-term, seasonal occupation characterized by some foraging and hunting is then indicated. Large scale plant processing was not being utilized, implying (via ethnohistorical information) that occupation was of the band level, noncommunal variety. Again, if seasonal ethnohistorical patterns were applicable in the Middle Archaic, this lower occupation can be expected not to have been occupied during summer plant processing. Freshwater mussels, however, are best collected in shallow water which occurs most frequently (at least at present) during winter and midsummer. I interpret this occupation as midsummer rather than winter for the following reasons: 
1. Rabdotus snail procurement would be least profitable during the winter.

2. Turtles are an abundant resource during summer.

3. Broken, nonutilized tools would not be expected during winter occupation.

4. Late spring-early summer and late summer-early fall sites should exhibit plant procurement tools (edge worn flakes, gouges, and grinding stones) with discrete processing concentrations such as concentrated burned rock--particularly if agave, prickly pear, or other plant foods were being processed.

The upper occupation of the site readily lends itself to ethnohistorical observation. Gouges, grinding stones, dart points, and areas of discrete functions evidence a multifunctional occupation. Transition to this from Zone 2 was made possible by depositional changes resulting from aggradation of the Frio River. Overbank sediments resulted in a richer floodplain environment while mesquite had expanded to the point that exploitation was economically feasible (expansion beginning, possibly, with the advent of more mesic conditions). The Zone 5 radiocarbon date of 3970 B.P. might mark a climate not radically different from today's permitting a subsistence pattern that remained intact until at least Late Prehistoric times.

Ethnohistoric accounts of summer aggregations to exploit prickly pear and other abundant plants could explain this upper occupation. Snails and mussels were still a prominent food item, apparently to no more or less an extent than in the Middle Archaic. Gouges, the most numerous recognizable tool, argue for the presence of wood working, just as the large, compact chert cobble hearths suggest large scale plant processing. Meager evidence for trade appeared in the surface collections where dart points common to the coastal areas and the Edwards Plateau were recovered. One small fragment of marine shell (unidentified) was also recovered in the surface collection. Such tenuous evidence might suggest affiliation of several groups for a period of time, probably for the purpose of mass plant exploitation or ceremonies (Newcomb 1961). The following points argue for a late summer-early fall occupation:

1. Prickly pear and mesquite yield best during the late summer and early fall.

2. Mussels and snails are still readily collectable.

3. Gouges, manos, edge worn flakes, and large burned rock concentrations are present in this occupational zone, but absent from previous ones indicating increased plant processing activities.

4. Dart points, scrapers, and discarded preforms indicate hunting and manufacturing activities.

5. A discrete function area containing five cores in various stages of reduction allude to processing and procurement of lithic material, often Tocated in eroded terraces near upland prickly pear patches.

6. The appearance of dart points and marine shells not normally found in the area argues for trade or multiple band meetings. 
Part II: Historic Investigations by Daniel E. Fox 


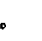




\section{HISTORIC SITES INVESTIGATIONS}

As part of the ongoing archaeological investigations at 41 LK $31 / 32$, two 19th century house sites were mapped and excavated in August 1978. Site 41 LK 202 was recorded in 1977 by personnel from the Cultural Resources Institute, Texas Tech University, as archaeological survey of selected areas at Choke Canyon was being carried out. The site was described as consisting of a stone house foundation with an associated scatter of mid- to late-19th century household refuse situated on an elevated terrace alongside the Frio River (Thoms, Montgomery, and Portnoy 1981:46). Original1y recorded as a prehistoric site, the historic components at 41 LK 31/32 were identified by CAR workers as Phase I test excavations were conducted on the site (Ha11, Black, and Graves 1982). In conjunction with the archaeological investigations, a limited historic research effort was conducted by Daniel $\mathrm{E}$. Fox to recover documentary evidence and other information pertaining to the history of ownership and occupation of the land on which sites 41 LK $31 / 32$ and 41 LK 202 are located. The research was approached so as to recover information that is site specific, or directly applicable to the archaeological investigation of sites 41 LK $31 / 32$ and 4.1 LK 202, and applicable to the evaluation of the historical and archaeological significance of these sites within the context of the cultural history of the Choke Canyon project area and greater south Texas.

\section{Historic Component at 41 LK $31 / 32$}

The historic structure at 41 LK $31 / 32$ was left in a wooded area during brush clearing of the reservoir area (Fig. 17,a). Flagstones marking a single chimney foundation were present on the southwest corner of an apparent house structure (Fig. 17,b). No wooden foundations were present, nor was any evidence of a trash dump observed around the structure's perimeter. Stones at the northeast corner of the house provided an indication of the length and width of the structure.

Excavations were directed towards: (1) delineation of wal1 foundations and other features, and (2) recovery of artifacts in the interior to provide material evidence both for dating and ascertaining the structure's original function. Ten $1-m^{2}$ units were laid across the foundation, oriented $90^{\circ}$ to the site grid. The chimney foundation was drawn to scale, as were the flat stones scattered at the northeast portion of the structure. Trowels were used to remove $10 \mathrm{~cm}$ of overburden, at which point a flat unit floor was maintained in an effort to detect foundation outlines, in situ artifacts, or a drip line from the structure's roofing (Fig. 18).

Recovery, unfortunately, was meager and soil staining was only noticeable in Unit $X$. The stain was found in a position suggestive of a wa11, though its irregular shape and relatively small size was more indicative of a rodent burrow.

A11 soil troweled from this portion of 41 LK $31 / 32$ was passed through $1 / 4-i n c h$ hardware mesh with a low pressure water stream. A11 materials were collected from the screen and returned to the Center for Archaeological Research for analys is by Daniel E. Fox. 
Figure 17. General Photos--Historic. a, view northeast across two sandstone rubble heaps marking collapsed chimneys on the historic component of $41 \mathrm{LK} \mathrm{31/32.}$ The tops of the highest rocks were the only parts of the ruin visible as excavations began; $b$, chimney foundation exposed beneath rubble of the southwesternmost sandstone concentration in the historic component at $41 \mathrm{LK} 31 / 32$. This foundation was beneath the rubble heap in the foreground of Figure $17, a$ as described above; c, view southwest across the area containing 41 LK 202 after brush was cleared, the Frio River is to the right; d, overview northwest across 41 LK 202 with excavations in progress; e, chimney footing at the northeast end of the structural foundation at 41 LK 202; f, cross section detail of chimney footing at the northeast end of the 41 LK 202 structure. 


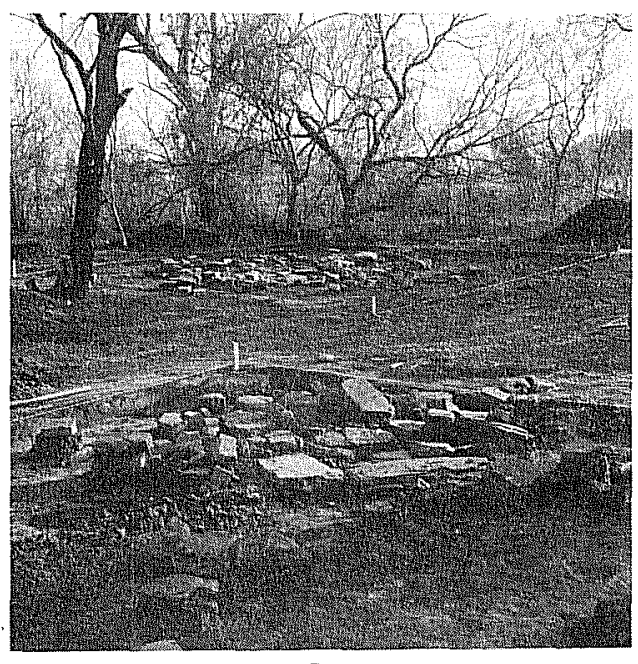

a
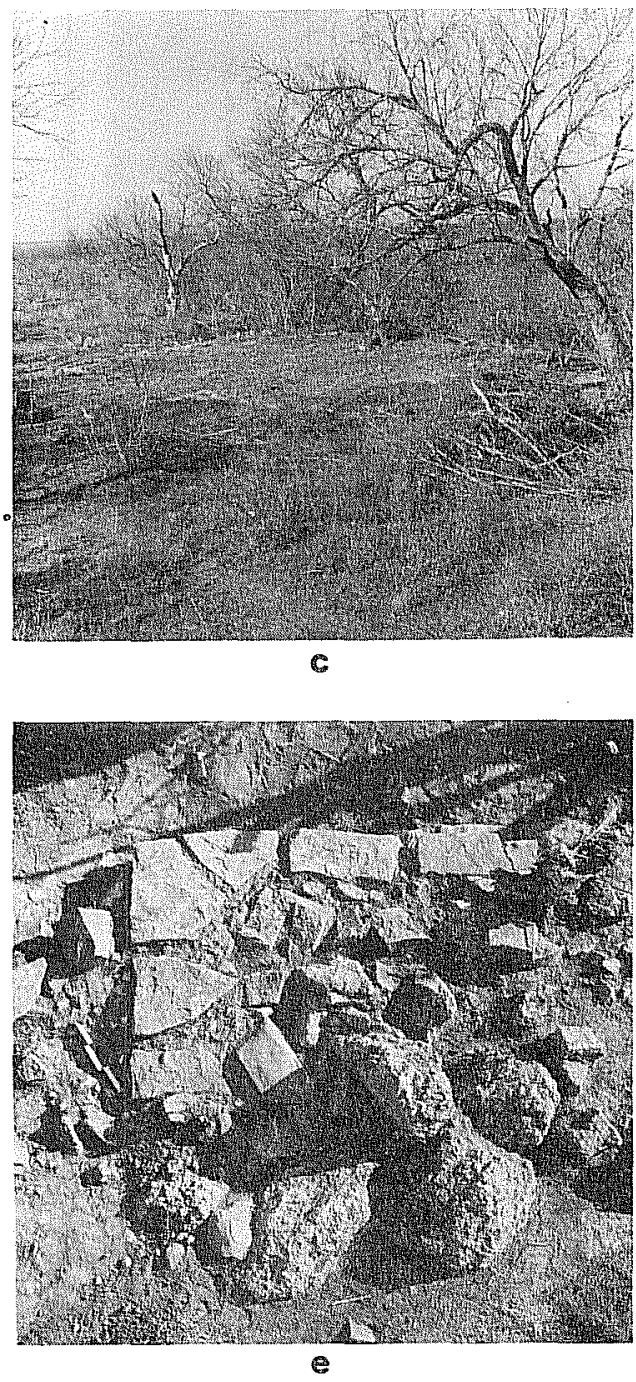
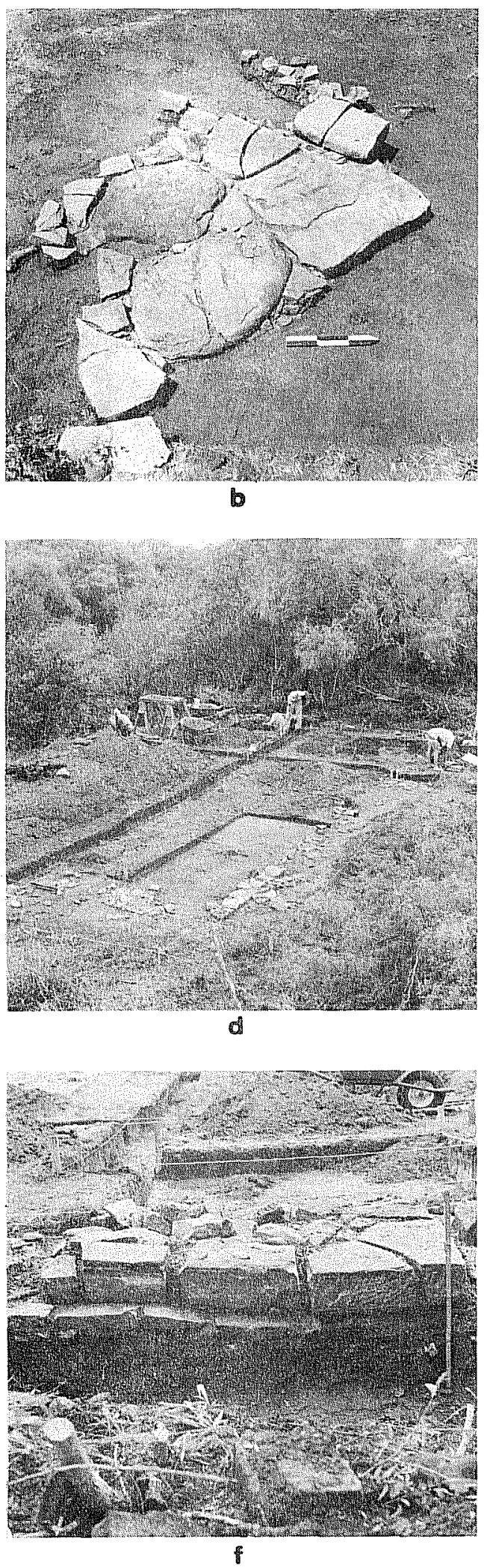


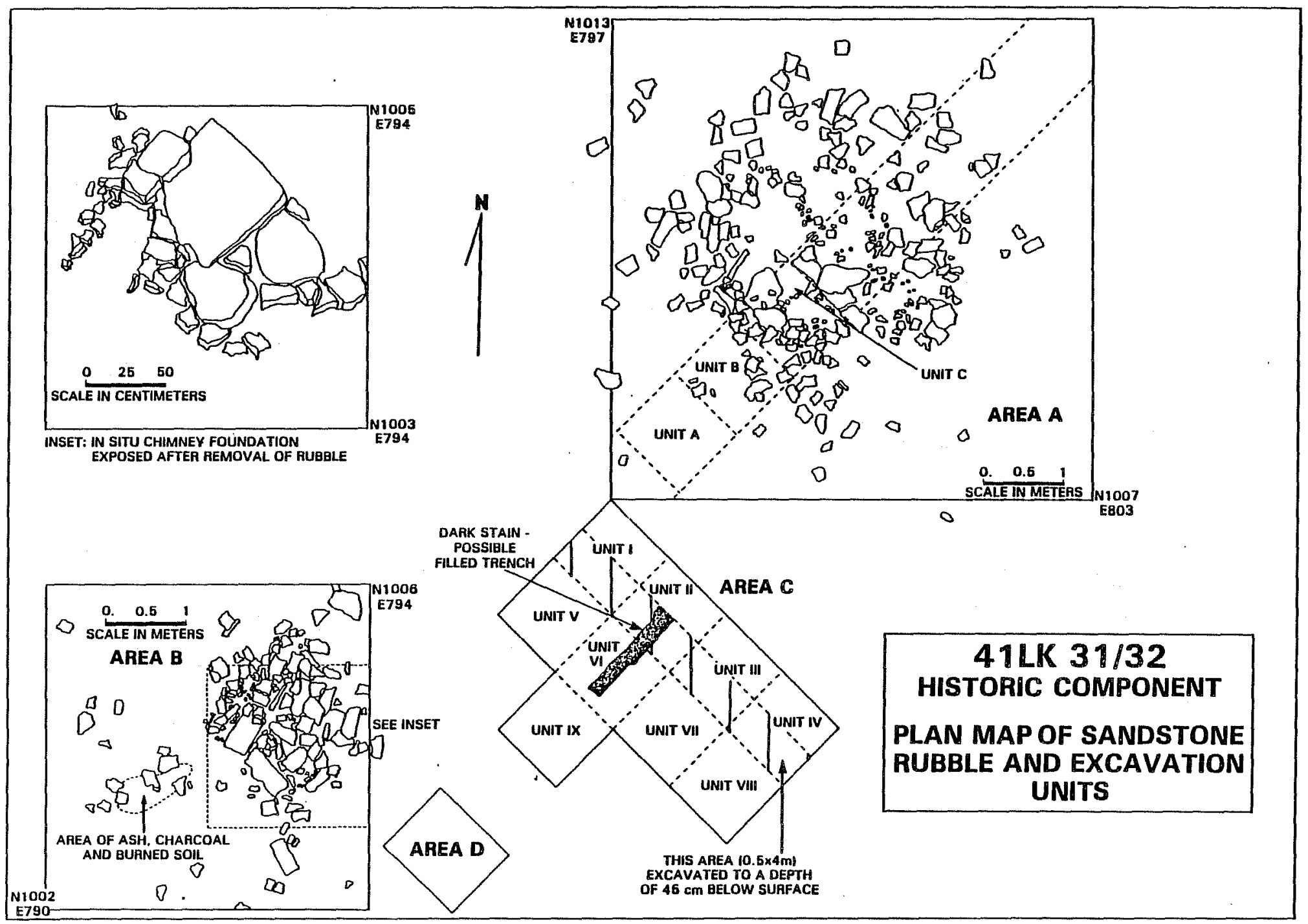

Figure 18. 41 LK 31/32 Historic Component--Plan Map of Sandstone Rubble and Excavation units. 
Historic Component at 41 LK 202

Lying on a bluff roughly $8 \mathrm{~m}$ over the present Frio River bed, this site was larger and better preserved than $41 \mathrm{LK} 31 / 32$ (Fig. 17, C). A foundation out line was present (oriented, again northwest-southeast) as we11 as a chimney foundation at the northwest corner (Fig. 17,d-f; 19). Building stones and the remains of a cistern were eroding off of the steep bluff into the Frio River.

Goals for investigating the rectangular structure were generally the same as those for the historic component at 41 LK 31/32. The grid, however, was oriented with respect to the foundation outline of the house. Four large units were staked to encompass the foundation's interior. A $50-\mathrm{cm}$ wide trench was dug through the foundation's interior at $90^{\circ}$ to the center point of each wal1, intersecting in the center. Troweling in this trench revealed no walls or stains to a depth of $50 \mathrm{~cm}$.

Foundations were cleaned and sketched, as were the fireplace remnants. Soil from the four interior $2-\mathrm{m}^{2}$ units was hand-screened. All artifacts recovered were retained for analysis.

Site Histories

Crucial to the interpretation of data obtained during the field investigations was a historical study of the two sites. Documentary research into the history of ownership and occupation of sites 41 LK $31 / 32$ and 41 LK 202 was focused primarily on deed, probate, survey, and abstract records stored at the Live 0ak County Courthouse, George West, Texas. Other historical references consulted include Dobie (1941), Fehrenbach (1968), Webb (1952), McDowe11 (1967), and Lynn, Fox, and 0'Malley (1977:173-178). Informal conversations with various Live Oak County and U.S. Bureau of Reclamation employees revealed that Hirsh N. Schwartz, mayor of Schulenburg, Texas, and Lee Mahoney of George West, Texas, are potential sources for oral histories of 20 th century ownership and occupation of the property on which sites 41 LK $31 / 32$ and 41 LK 202 are located. However, it is doubtful that these gentlemen can contribute reliable information about the mid- to 1ate-19th century occupation of these sites. Basic information recovered from county records and historical references concerning ownership and occupation of sites 41 LK $31 / 32$ and 41 LK 202 is presented in Table 11. Following is an elaboration of this data.

In 1828, John McMullen and James McGloin were awarded a colonization grant to settle a large expanse of prairie between San Antonio and the Nueces River (see Lynn, Fox, and 0'Malley 1977:173-174). The property on which sites 41 LK $31 / 32$ and 41 LK 202 are located was part of one league and one labor of land granted to Mark Killely (sometimes spelled Killelee or Killeley) as a colonist. It is doubtful that Anglo-American occupation of the Killely Survey took place before the late 1850s. Settlement efforts were discouraged by the fear of Indians, by the difficulty of farming without irrigation, and by Mexican politics (ibid.:173). 
TABLE 11. CHRONOLOGY OF HISTORIC SITES 41 LK 31/32 AND 41 LK 202

Dates Documentary Information

References

1828-1830 Mexican Government awards colonization grant to John MCMullen and James McGloin. A headright of one league and one labor of the Frio River valley is granted to colonist Mark Killely.

1856

Live Oak County is organized and its county seat, Oakville, is founded about 5.5 miles east of the M. Killely Survey.

1857, John G. King sells five Negro slaves, 800 head Aprii 17 of cattle, and 25 head of horses to his wife, Elizabeth C., for $\$ 10$.

1857, Apri] 18

Michael O'Hely and his wife, Mary, of Live Oak County sel1 154.2 acres fronting on the Frio River on the M. Killely Survey to Elizabeth C. King, of Live Oak County for \$212.

1857, June 1

1857, Juty 16

1858 , March 4-5

1858 , March 4-5

1880 , August 21

1881 , May 16
Michael O'Haley (O'Hely) and his wife, Mary, of Live Oak County se11 154.2 acres fronting on the Frio River, part of the M. Killely Survey, and adjoining Elizabeth $C$. King's tract, to Thomas King for $\$ 212$.

John G. King and his wife lease their stock for five years to A. W. Pelham and W. Slaughter.

San Patricio County District Surveyor P. S. Hagy surveys 1320.5 acres of the M. Killely Survey for Thomas King.

San Patricio County District Surveyor P. S. Hagy surveys 1320.5 acres of the M. Killely Survey (adjoining the west boundary of Thomas King's 1320.5 acre tract) for John King.

John G. King and his wife, Elizabeth C., "citizens of the County of Bee," sell two 154.2 acre tracts ( 308.4 acres) on the M. Killely Survey to James Murray of Bee County for $\$ 1$.

James 0. Gaffney, administrator of the estate of Walter Henry of San Patricio County, sells $8812 / 3$ acres of the Thomas Henry Survey (adjoining the east boundary of the M. Killely Survey) to Rose Mahoney of San Patricio County.
Lynn, Fox, and 0'Malley $1977: 173-174$

Webb Vol. 2 $1952: 298$

Deed Records Vol. A:52-53

Deed Records Vol. A:51-52

Deed Records Vol. A:62-63

Deed Records Vol. B:85-86

Abstract and Survey Vol. 1: 290

Abstract and Survey Vol. 1: 291

Deed Records Vol . F:323324

Deed Records Vol. F:528529 
TABLE 11. (continued)

Dates

1881 ,

December 9

Early 1890s

1897,

August-

October

1913,

March 13

1918,

May

1919 ,

March 13

1936,

January 13

1977
Documentary Information

References

Deed Records

Vol. F:621

Deed Records

Vol. K:539

Deed Records

Vol. L: :323-

337

Probate

Minutes Vol.

B: 142-146

Probate

Minutes Vol.

$c: 8-10$

sisting of 3740 acres "known as the M. K. Mahoney

Ranch" and acreage in San Patricio County.

Mary Bluntzer and Mark K. Mahoney of Nueces

County and Rose Agatha Mahoney, Aggie Mahoney and

Ada J. Mahoney of San Patricio County, all heirs

of M. K. Mahoney, sel1 $3812 / 3$ acres of the

T. Henry Survey, 2719 acres of the M. Killely

Survey and 640 acres in the Simmons Subdivision

(a speculative development to the south, on the

Nueces River) to Julius Schwartz.

Elizabeth A. McCowan and her husband Hugh of San

Patricio County, Michael L. Mahoney of Atascosa

County, Margaret F. Baldeschwiler and her hus-

band M. F. of San Patricio County, Catherine J.

Bluntzer and her husband William D. of Nueces

County, and Albert F. Mahoney of Arizona convey

their interests in the Rose Mahoney estates to

Isy Schwartz, Joe W. Schwartz, Amy Schwartz and

Hirsh N. Schwartz, all of Fayette County.

Hirsh N. Schwartz of Schulenburg, Texas, turns

over the Schwartz place to the U.S. Bureau of

Reclamation.
Deed Records Vo1. 59:95-

97 


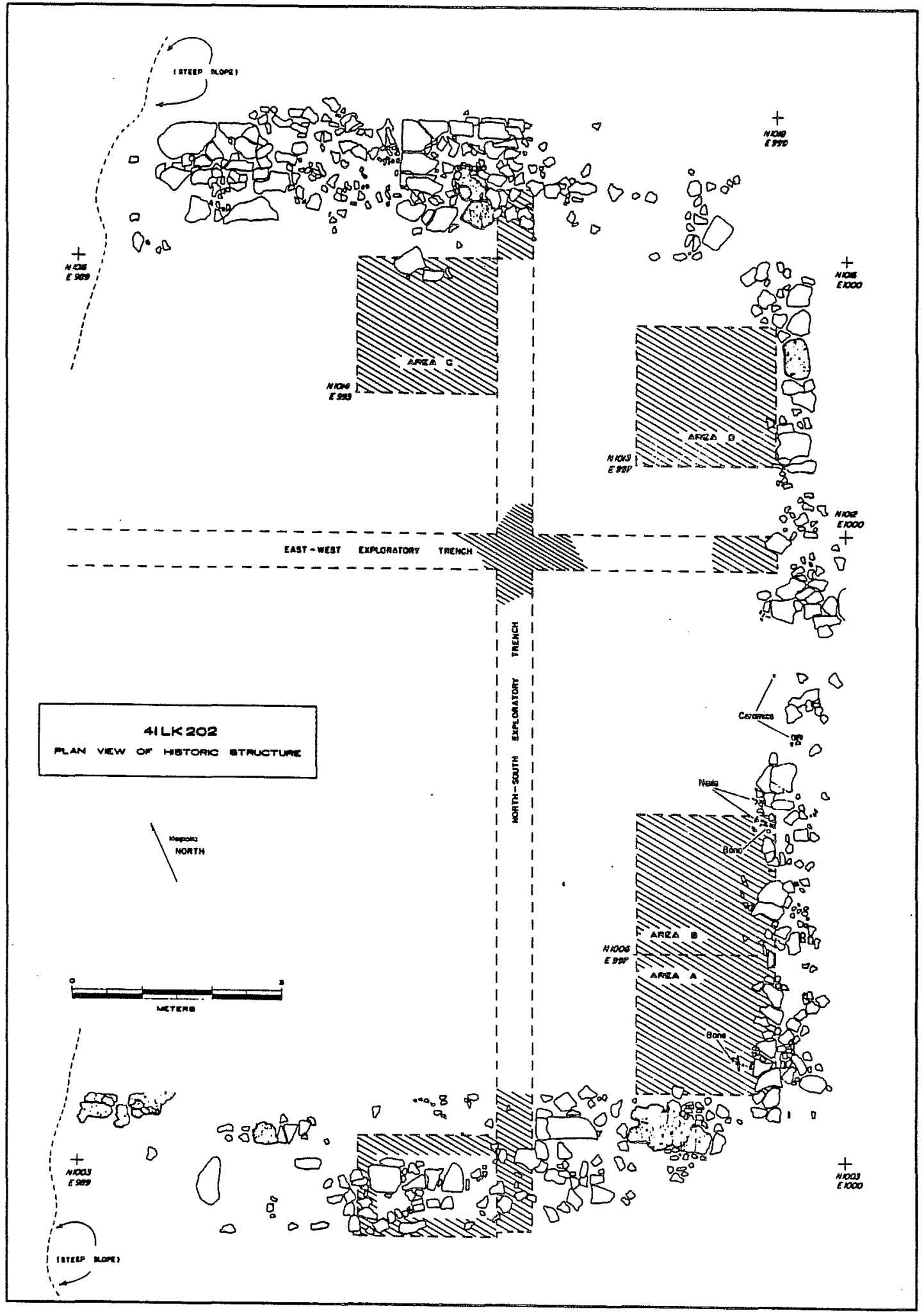

Figure 19. 41 LK 202 Historic Structure--Plan View and Excavations. 
After Texas joined the United States, the south Texas frontier pushed westward away from developing communities on the Texas coastal plain (Fehrenbach 1968: 296-297). The town of Oakville, founded in 1856 as the county seat of the newly organized Live Oak County (Webb Vol. 2 1952:298), probably became the principal townsite that helped to populate the lower Nueces, Frio, and Atascosa River valleys. The earliest records of ownership of the M. Killely Survey are dated April and June 1857, and include deeds to adjoining 154.2 acre tracts sold to Elizabeth C. King, wife of John G. King, and Thomas King by Michael 0'Hely (sometimes spelled O'Haley) and his wife, Mary (Deed Records Vol. A: $51-52,62-63)$. How and when the 0'Helys acquired this land is not yet known; however, it does not seem likely that they occupied it.

The nature of John and Elizabeth King's livelihood is reflected by a deed dated Apri1 17, 1857, one day before Elizabeth was deeded the 154.2 acre Frio River tract. For $\$ 10$, John King conveyed the following property to Elizabeth: ". . five negro slaves," including "one negro man named John aged about forty years, one negro boy named Ned two years old, one negro woman named Mary, one boy name Pete aged four years, one child named Ben four months old, eight hundred head of stock cattle (ear marked shallow fork in the left ear and under bit in the right) branded JK-CK,..." and ".. . twenty-five head of horses..." (Deed Records Vol. A 1857:52-53). The Kings may have been descendents of Southern planters or yeomen farmers who as Texas colonists adopted cattle raising (Dobie 1941:29; Fehrenbach 1968:309, 559).

The possibility of a temporary occupation of the M. Killely Survey is suggested by the record of an agreement dated July 1857, in which John and Elizabeth King would lease their stock to $A$. W. Pelham and W. Slaughter. The Kings agreed to furnish Slaughter and Pelham with two horses, provisions, clothing, and ". . means of paying off hirelings for the stock. . ." In return for this, and ". . 1/4 of the increase..." in the stock at the end of five years, Slaughter and Pelham agreed to ". . . gather all the scattered stock in any different parts of the County that can possibly be collected. . . "and at the end of five years to keep the stock ". . . as much so in the immediate Range as they possibly can..." (Deed Records Vol. B 1857:85). Perhaps Slaughter and Pelham occupied the King's property temporarily.

Although no record has been found which states that Thomas or John and Elizabeth King actually lived on their Frio River tracts, it seems possible that sites 41 LK $31 / 32$ and 41 LK 202 are the remains of household occupations by John and Elizabeth King and Thomas King, respectively. In March 1858, San Patricio County Surveyor P. S. Hagy surveyed 1320.5 acres of the M. Killely Survey for Thomas King and the adjoining 1320.5 acres of the same survey for John King (Abstract and Survey Vol. 1 1858:290-291).

It is also possible that one site (perhaps 41 LK 202) was occupied by John and Elizabeth King and that the other housed Elizabeth's five Negro slaves. In any case, occupation by at least one of the Kings of a house near the bank of the Frio River is indicated by references made in the metes and bounds of a deed dated 1897 to ". . . the old chimney of King's house... " and ". . . the chimney of the King Place" (Deed Records Vol. L 1897:330-331).

In August 1880, John and Elizabeth King sold their original 154.2 acre tract and an adjoining 154.2 acre tract (probably Thomas King's) to James Murray for 
$\$ 1$ (Deed Records Vo1. F 1880-1881:323-324). Perhaps John and Elizabeth retired to Oakville at this time. In December 1881, Murray sold the King place to Rose Mahoney of San Patricio County (ibid.:621). In succeeding years, Rose Mahoney acquired additional lands in the vicinity of the M. Killely Survey (Deed Records Vol. F 1880-1881:528-529), but no evidence could be found which suggests that the old King place was occupied.

In 1897, Rose Mahoney's estate was divided among her heirs, most of whom apparently resided in San Patricio County (Deed Records Vo1. L 1897:323-337). M. K. Mahoney was partitioned 573 acres of land upon which the " . . old King place .." was located (ibid.:330-331). M. K. may have occupied the property after (and possibly before) 1897. In 1918, his estate, valued at $\$ 35,000$ included 3740 acres ". . known as the M. K. Mahoney Ranch . . " (Probate Minutes Vo1. C 1918:8-10).

In 1919, the heirs of M. K. Mahoney sold the ranch to Julius Schwartz (Deed Records Vo1. 2 1919:565-569). In 1936, the heirs of Rose Mahoney and M. K. Mahoney conveyed their interests in the estates to Hirsh N. and other members of the Schwartz family of Fayette County (Deed Records Vo1. 59 1936:95-97). Until recent reclamation of the Schwartz place by the U.S. Government, the property on which 41 LK $31 / 32$ and 41 LK 202 are located has been used primarily for hunting and cattle grazing.

\section{Analysis of Historic Artifacts}

The field work described earlier yielded a wide range of historic artifacts from the historic component at 41 LK $37 / 32$ and from site 41 LK 202. A description of these specimens is presented here.

\section{Construction Materials (1350 specimens; Fig. 20)}

A variety of iron hardware and windowpane glass reflects the nature of mid-19th century building construction at sites 41 LK 202 and 41 LK 31/32 (Table 12). Square cut nails, including at least three standard sizes, make up the majority (1063 specimens) of the sample of construction materials. All are common cut (as opposed to fencing, casing, finishing, etc.,) nails and are typical of 19th century frame construction (Fontana and Greenleaf 1962:44-50). Two handwrought nails may have been made at the sites either to supplement the supply of cut nails or to serve some special purpose. A cluster of wire nails (all 6d, or "box nails") probably represents a 20th century fence gate or an early 20 th century renovation of the south end of the ruins of the structure at site 41 LK 202.

A bolt, a wood screw, and a butt hinge (Fig. 20,d) might be the sort of hardware used to fasten door jambs and window casings to the structure at site 41 LK 202. A heavy wrought pintle (a bar $17 \mathrm{~cm}$ long and $1.2 \mathrm{~cm}$ thick with a loop or eye in one end) could have been used as a hinge for a heavy door, or more likely as a support for a fireplace crane (Fig. 20,b). A fragment of a thumb latch (Fig. 20,g) and two hand-wrought staples probably represent a simple means of latching doors without the use of door knobs and locks (Fig. 20,h). 


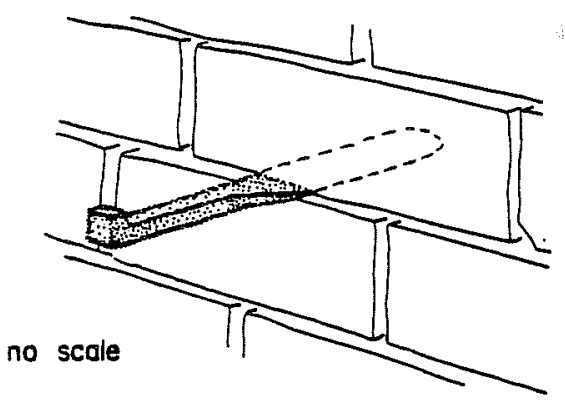

a

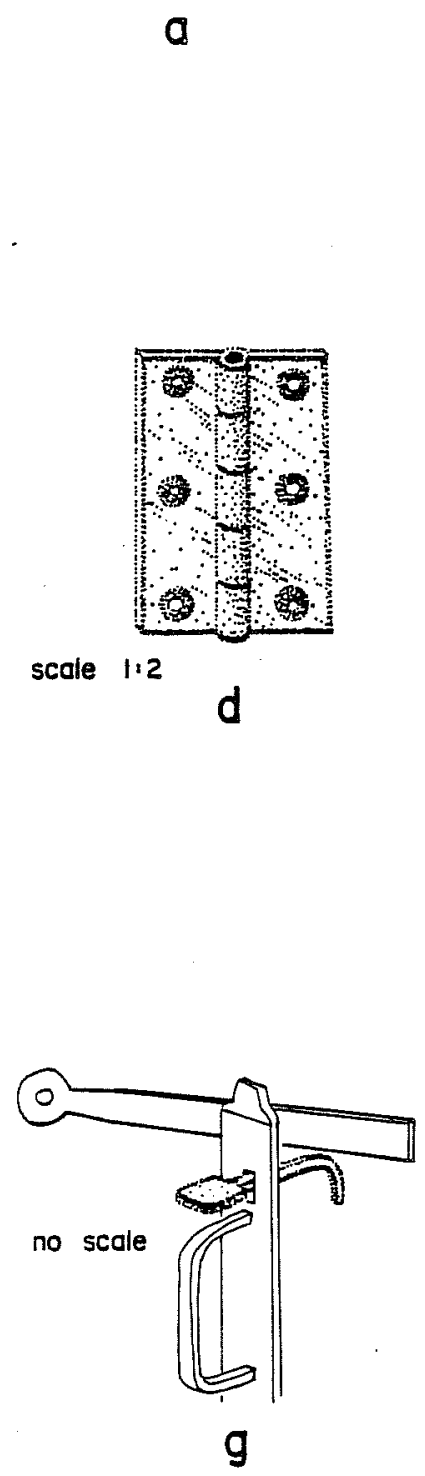

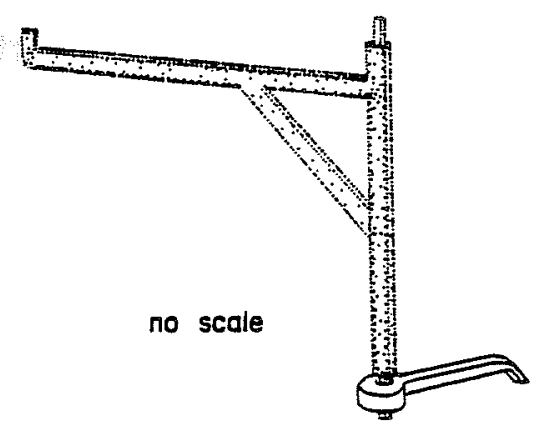

b
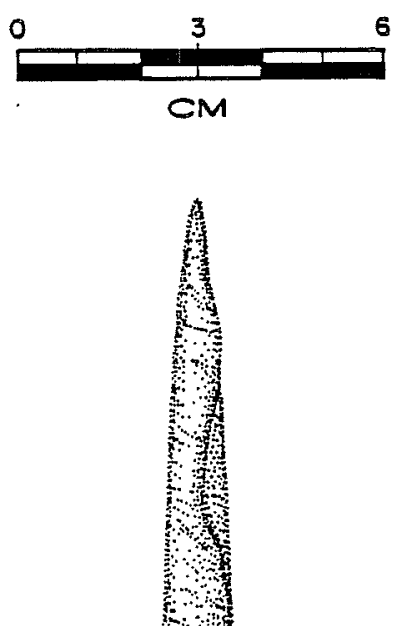

$f$

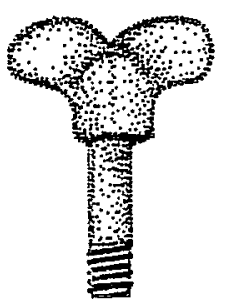

e

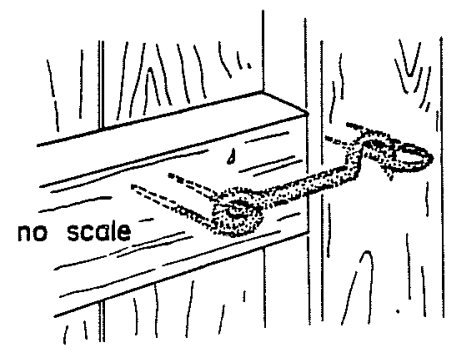

h

Figure 20. Metal Items and Construction Materials. a, wrought iron tool or fireplace hardware; b, heavy wrought iron door or fireplace crane pintle; $c$, metal arrow point; d, butt hinge; e, iron adjustment wing bolt; $f$, rolled, pointed tin cone; $g$, door latch fragment; $h$, wrought iron staples. 


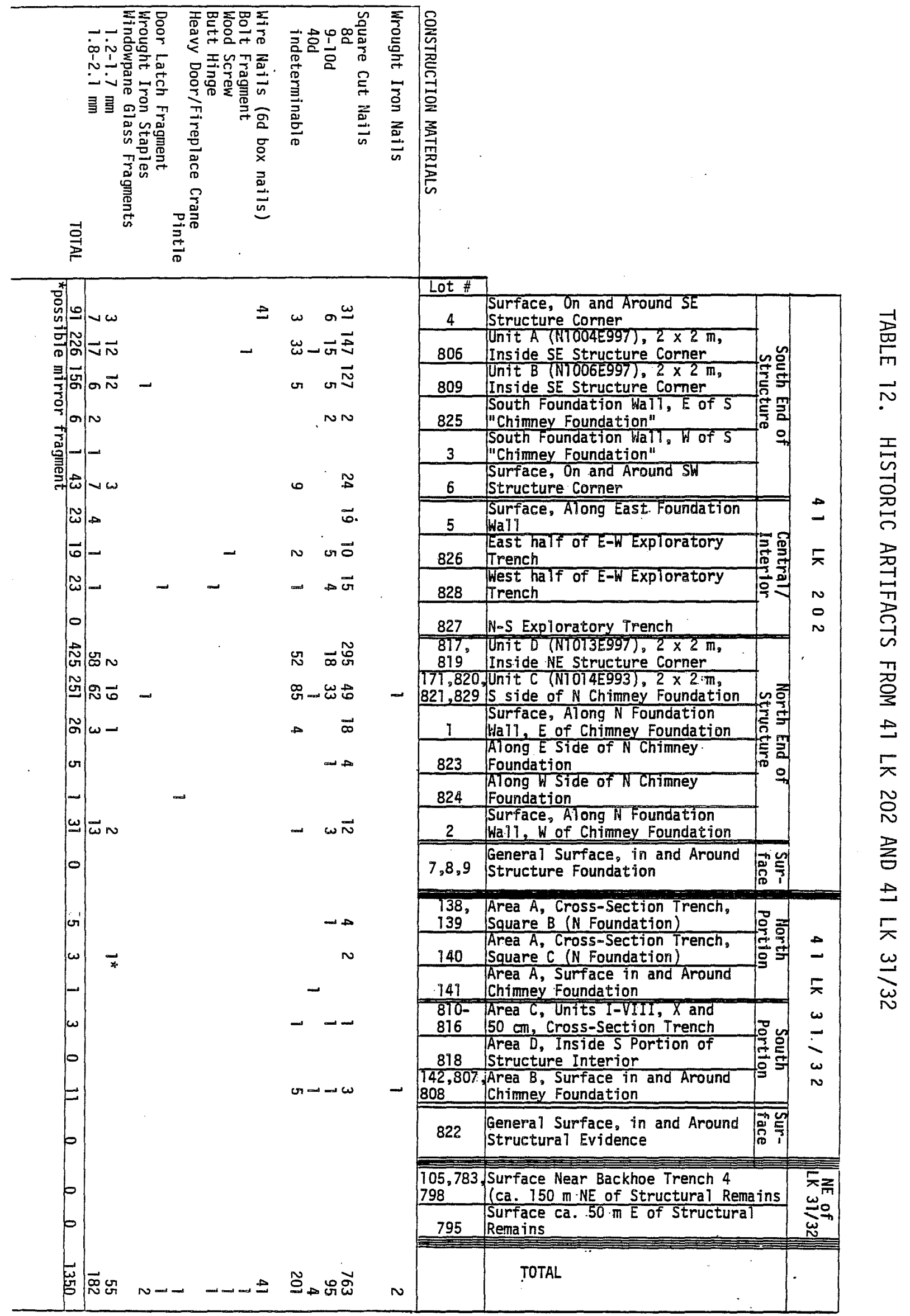


TABLE 12. (continued)

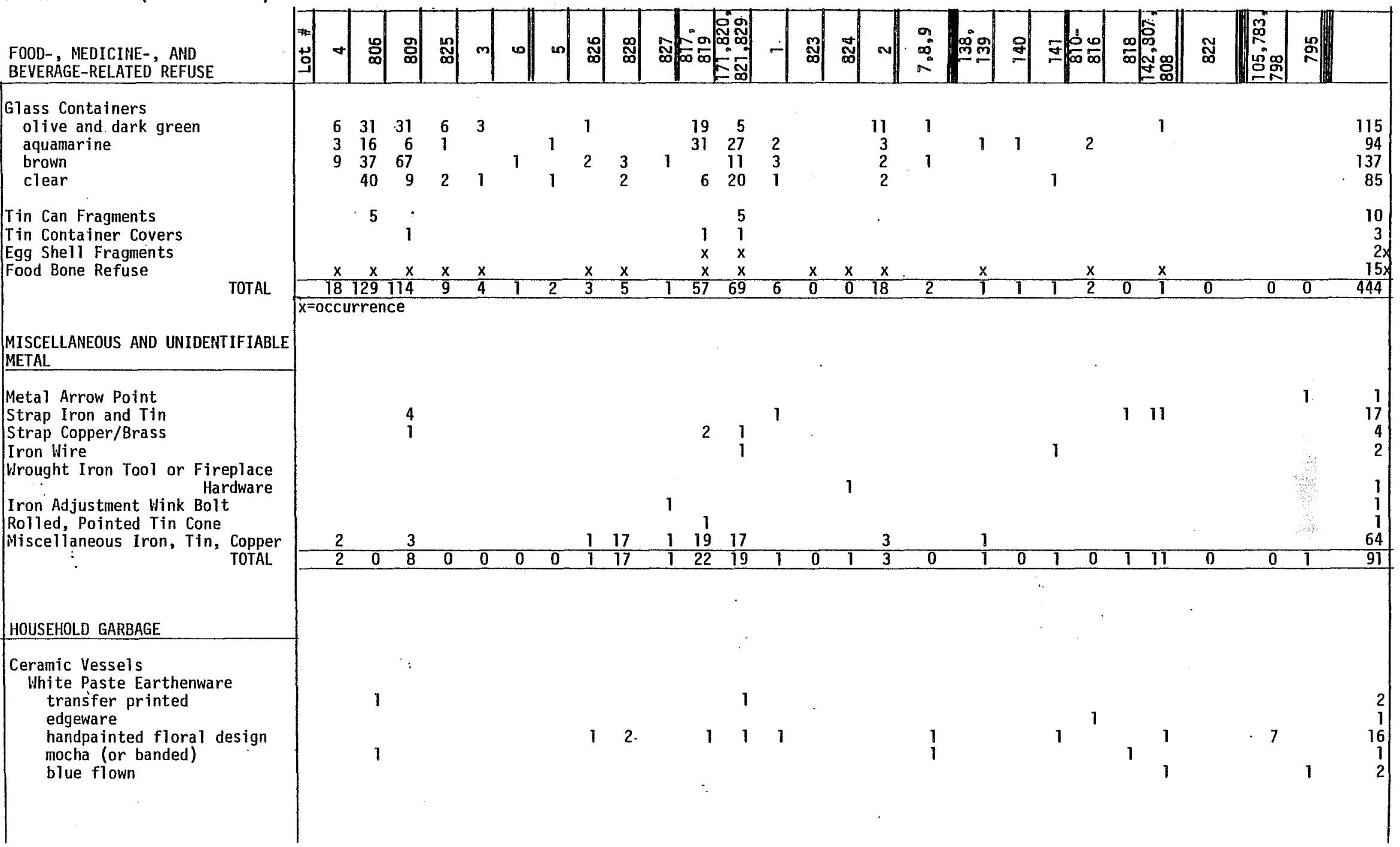




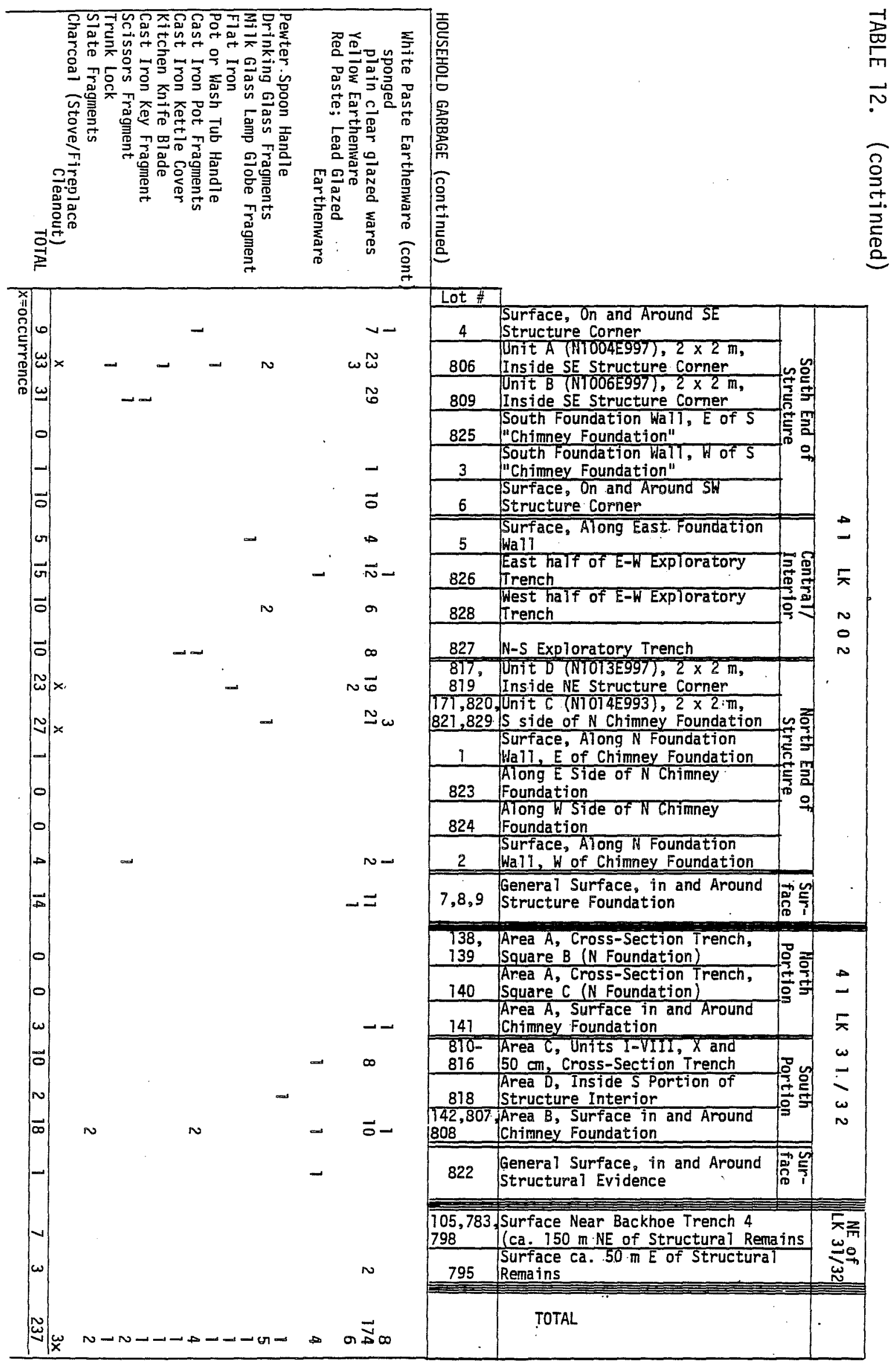


TABLE 12. (continued)

HARNESS TRAPPINGS AND AGRICULTURAL EQUIPMENT

Buckles (Cinch and Bridte)

Ring Bit Fragment

Harness Ring

Bridle Rosette

Horse Shoe

Horse Shoe Nails.

Wiffle Tree Band

Chain Links

Hower Blade Fragment (?)

Fence Staples

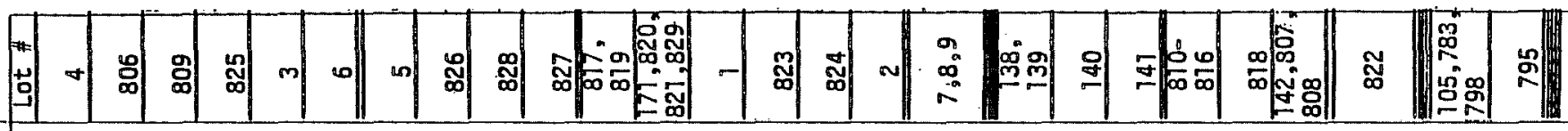

TOTAL.

\section{FIREARM-RELATED ITEMS}

\section{Cartridges}

.44 cal. Rimfire Henry (Winchester)

.44 cal. Rimfire, Extra-Long (Ballard)

45 cal. Rimfire, Short (Remington) Single-Action Army Revolver

.44 cal. Centerfire, Smith and Wesson (American)

.44 cal. Centerfire, Smith and Wesson (Russian)

.41 cal. Rimfire, Short (Rem-

ington Derringer)

Lead

$.36 \mathrm{cal}$. Colt, cut

28 cal. (?) Spir from Pistol

Bal1

Unidentifiable

Brass Patch Box Cover Fragment Powder Container Covers

Pistol Flint

Poss. Gunflint or Strike-0-1ite

Poss. Gunflint or Strike-0-lite
TOTAL

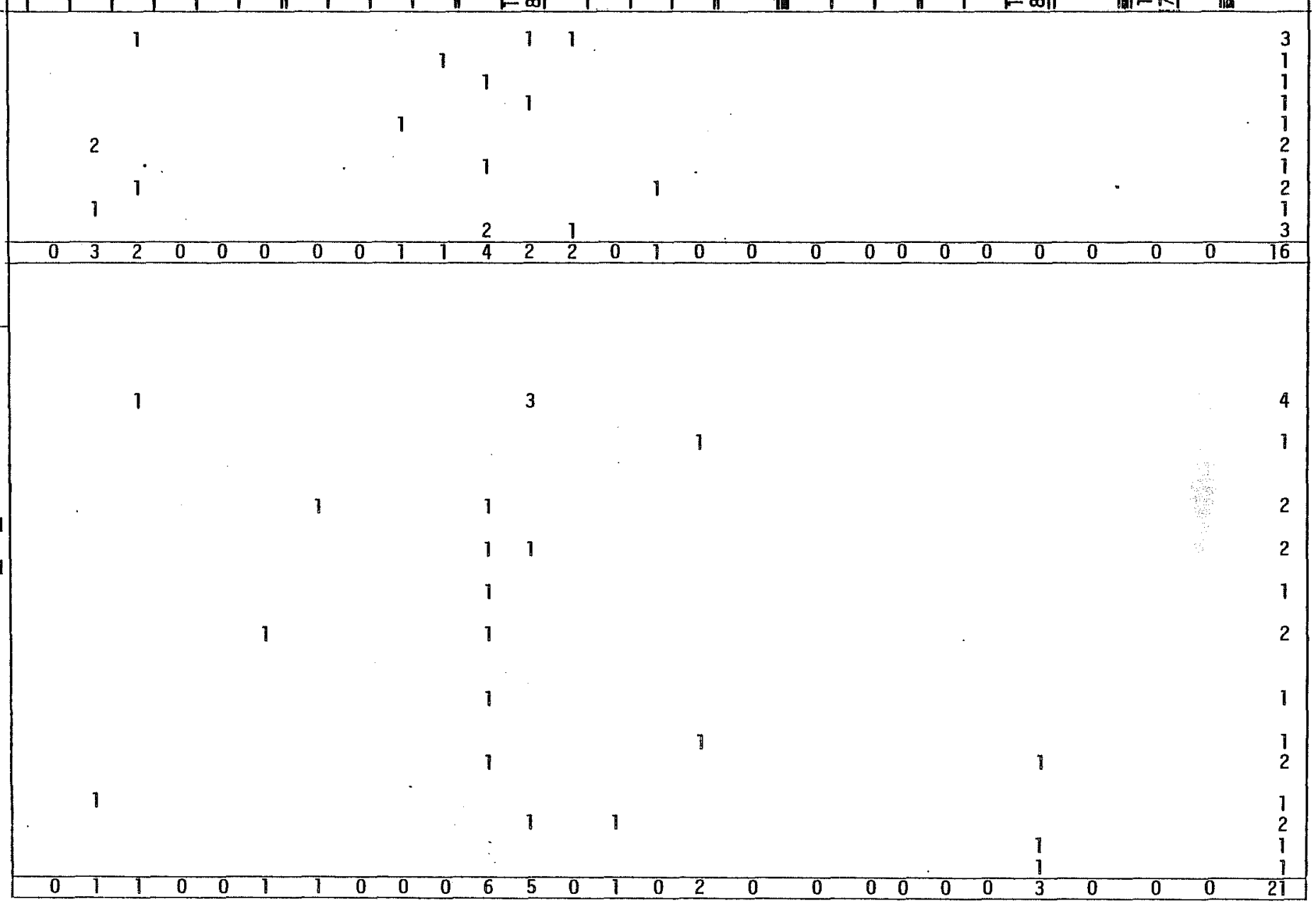




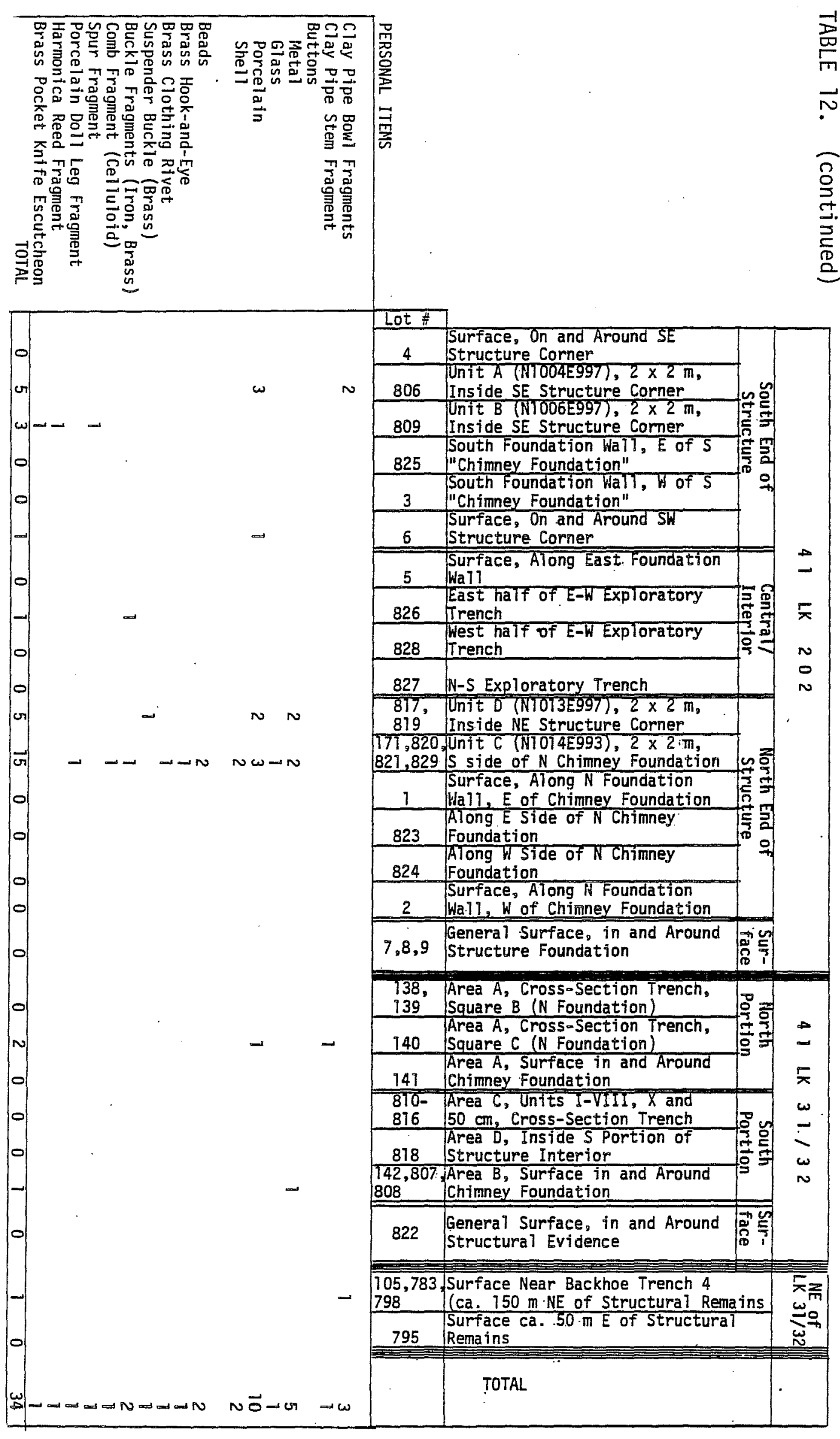


Windowpane glass fragments seem to occur in two thicknesses $(1.2-1.7 \mathrm{~mm}$ and $1.8-2.1 \mathrm{~mm})$. However, it is quite possible that weathering (patination) and production tolerance could account for the overall variation in thickness of only $0.9 \mathrm{~mm}$ and that a 11 of the window glass from site 41 LK 202 may be representative of one standard pane size, perhaps $12 \times 19-1 / 4$ inches in dimension and about $2 \mathrm{~mm}$ thick (Roberson 1974:24). Only one sample was recovered from site $41 \mathrm{LK} 31 / 32$. A7though it measures $1.5 \mathrm{~mm}$ thick and conforms to the range of the rest of the sample of windowpane glass, it is possible that it is a fragment of a mirror, instead of a windowpane.

Food-, Medicine-, and Beverage-Related Materials (444 specimens; Fig. 21)

The sustenance of the occupants of sites 41 LK 202 and 41 LK $31 / 32$ is reflected by fragments of glass containers, tin cans, tin covers for cardboard or metal containers, egg shells, and animal bones (Table 12).

01 ive and dark green, aquamarine, brown (amber), and clear glass sherds represent two principle vessel forms produced during the second half of the 19th century. 01 ive and dark green cylindrical and panel bottles probably contained alcoholic beverages (Fig. 2l,c). Three dark green fragments are from the bases of handmade (free-blown) cylindrical wine bottles with kickups and improved pontil scars (Fig. 21,j) dating from before about 1880 (Munsey 1970:48). Some sherds from olive green panel bottles, with molded bodies and hand-finished rims, have raised letters. Five such bottle fragments bear portions of the Tabe1 "UDOLPHOWOLFE'S/AROMATIC SCHNAPPS/SCHIEDAM." These 14-ounce bottles had cork stoppers and contained almost $21 \%$ alcohol by volume. They were produced during the 1860s (Switzer 1974:36, Fig. 49).

A greater variety of vessel shapes is represented by sherds of aquamarine bottle glass. An oval base of a panel bottle has a rough pontil scar. Neck and rim sherds (Fig. 21,e) from three aquamarine bottles are hand-finished. Three body sherds from cylindrical bottles bear unidentifiable portions of raised labels. These and most of the other aquamarine bottle sherds probably are from medicine and alcoholic beverage bottles with mold-made bodies and hand-finished rims (Fig. 21,b,g) dating technologically to the 1860s and 1870s (Ma11ouf, Fox, and Briggs 1973:181; Lynn, Fox, and O'Malley 1977:197). Many sherds are from sma11, thin-walled bottles or vials. Others are from larger bottles. One body sherd represents a cathedral panel bottle, a vessel form used during the 1860s as a container for pickles, honey, and pepper sauce (Switzer 1974:51-60).

The entire sample of brown bottle glass seems to be from bitters bottles, many of which were square or rectangular panel bottles and a few which were cyl indrical (Fig. 21,h,i). By 1870, the vast majority of bottles containing bitters, a popular "medicine" during the 1860s and 1870s, were brown (or amber) in color (Watson 1965:39).

Large and small food, medicine, and beverage containers are represented by sherds of clear glass. Most clear glass bottles appear to have had mold-made bodies and hand-finished rims (Fig. 21,a,d,f) dating technologically to the 1860s and 1870s (Ma17ouf, Fox, and Briggs 1973:181; Lynn, Fox, and 0'Ma17ey 1977:197). Some sherds probably are from smal1 medicine vials. Others are 
Figure 21. Food-, Medicine-, and Beverage-Related Materials. a, clear bottle rim (hand finished); b, aquamarine bottle neck (hand finished); c, olive-green bottle rim (hand finished); $d$, clear glass bottle or vial rim (hand finished); e, aquamarine glass bottle or vial rim (hand finished); f, clear glass jar (?) rim (hand finished); g, aquamarine rectangular panel bottle base (handmade with pontil scar); $h$, brown square panel bottle base (mold-made); $i$, brown square panel bottle base (mold-made); $j$, olive-green cylindrical bottle base (with kickup and improved pontil scar). 


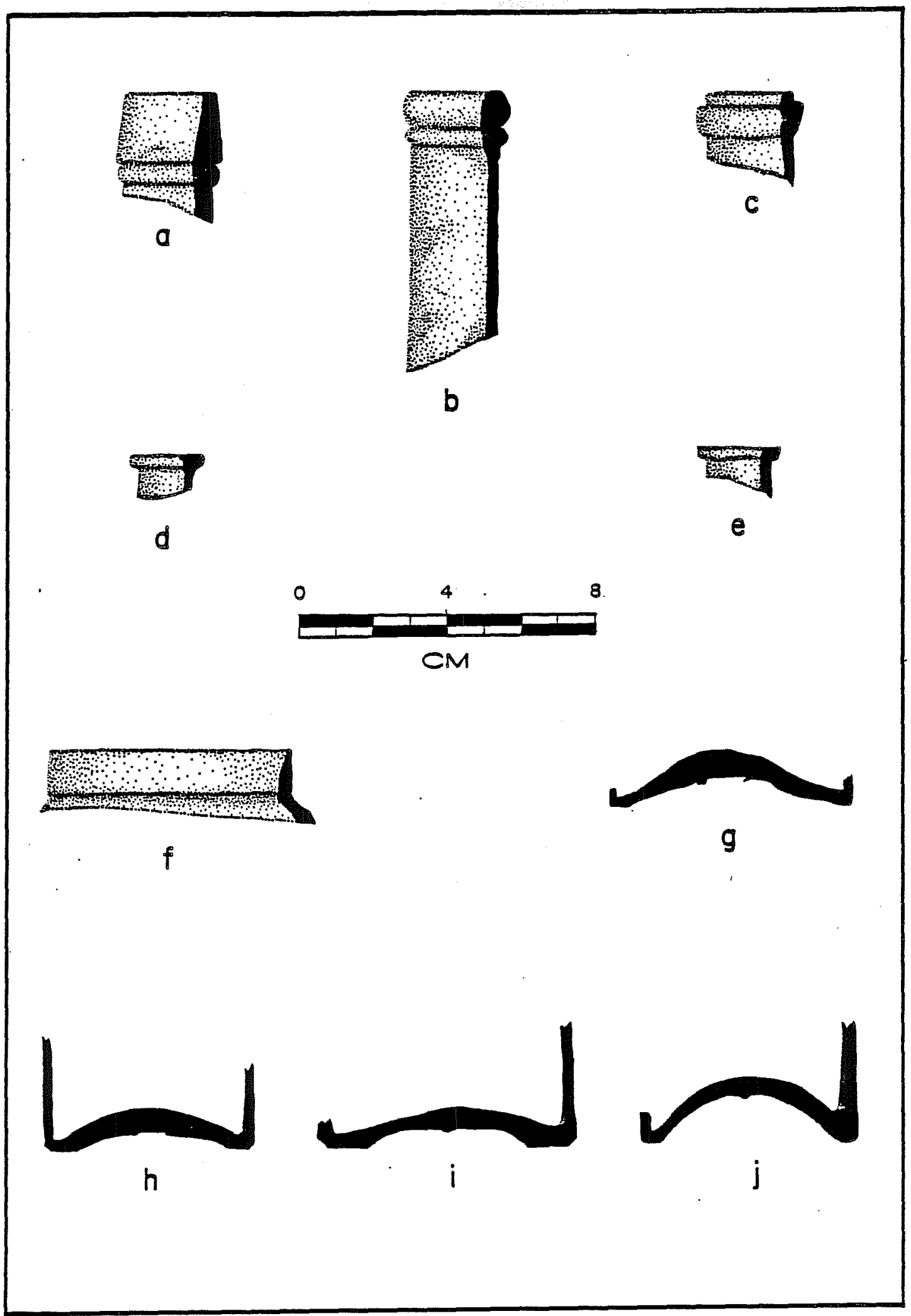


from larger cylindrical or flask-shaped beverage bottles. One rim sherd from a broad-mouthed bottle or jar (6.2 cm interior diameter) may be from a container for mustard (Switzer 1974:48, Fig. 68) or some other food and probably dates to the 1860s or 1870s.

Tin can fragments are few in number (10) and not identifiable as to form or content. Tin cans were produced thoughout the 19th century, particularly during the late 1880s, and were used as containers for a variety of meat and vegetable foods, condensed milk, and other products (Fontana and Greenleaf 1962:67-68). Tin container covers probably fitted over tin and/or cardboard containers for spices, tobacco or other products. Egg shells probably represent chicken eggs produced and consumed at site 41 LK 202.

Harold Woolridge of Austin analyzed 15 samples $(65 \mathrm{gm})$ of bone collected from sites 41 LK 202 and 41 LK $31 / 32$ (Table 12). Identifiable domesticated 1ivestock include cow, sheep and/or goat, and pig. Game animals include deer and/or antelope, wild turkey, rabbit, aquatic turtle and possibly wild cow and bison. The bones of a rat and a snake probably represent inhabitants of the airspace beneath the structure at site 41 LK 202. Cattle, sheep and/or goats raised on the farm probably were the most common animal foods, although the variety of bones of wild animals indicate that hunting was an important part of subsistence. Not only special cuts, but various body portions are represented by cut and unaltered food bones.

Household Items (237 specimens; Fig. 22)

Fragments of ceramic plates, cups, bowls, and other vessels (216 sherds) comprise most of the evidence of household occupations at sites 47 LK 202 and 41 LK 31/32 (Table 12). Decorated British-made white paste earthenwares, including transfer printed (Fig. 22,C), edgeware (Fig.22,a), hand-painted floral design (Fig. 22,h), mocha (or banded slipware) (Fig.22,d), flown blue (Fig. 22,f), and sponged designs (Fig. 22,b), were imported before the Civi] War, although these wares may have been used and discarded during the 1860 s and 1870s. Some sherds of plain white paste earthenware probably are from the undecorated portions of decorated vessels. Most plain clear glazed sherds probably represent the influx of plain ware (including some ironstone) imported after 1860 (Davis and Corbin 1967:26). One sherd from the bottom of a plate bears the printed maker's mark, "WARRANTED/IRONSTONE CHINA/TRADE MARK/JOHN EDWARDS," which refers to a Staffordshire pottery and probably dates from between the 1860s and 1891 (Godden 1964:231; 1971:67).

Six sherds of yellow ware (Fig. 22,i) probably are from mixing bowls like those commonly advertised in mail-order house catalogues of the late 1800s and early 1900s (Raycraft and Raycraft 1975:Plate 16). Four sherds of red paste, leadglazed earthenware (Fig. 22, e,g) are from serving or storage bowls. This type of pottery has been produced in Mexico for over 300 years (Fox 1974:55).

In addition to pottery sherds, a pewter spoon handle (Fig. 23,e), drinking glass, tumbler or mug fragments, cast-iron pot, kettle fragments (Fig. 23,d), and a kitchen knife blade are representative of food preparation and consumption. A flat iron (Fig. 23,b), a pot or wash tub handle, and two scissor fragments (Fig. 23,a) reflect other household or personal items. A cast-iron 


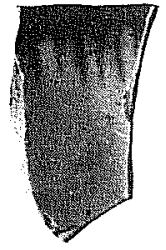

a

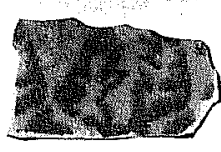

b

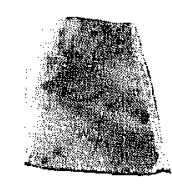

C

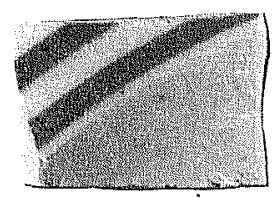

d

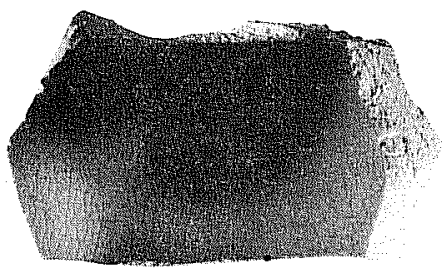

0
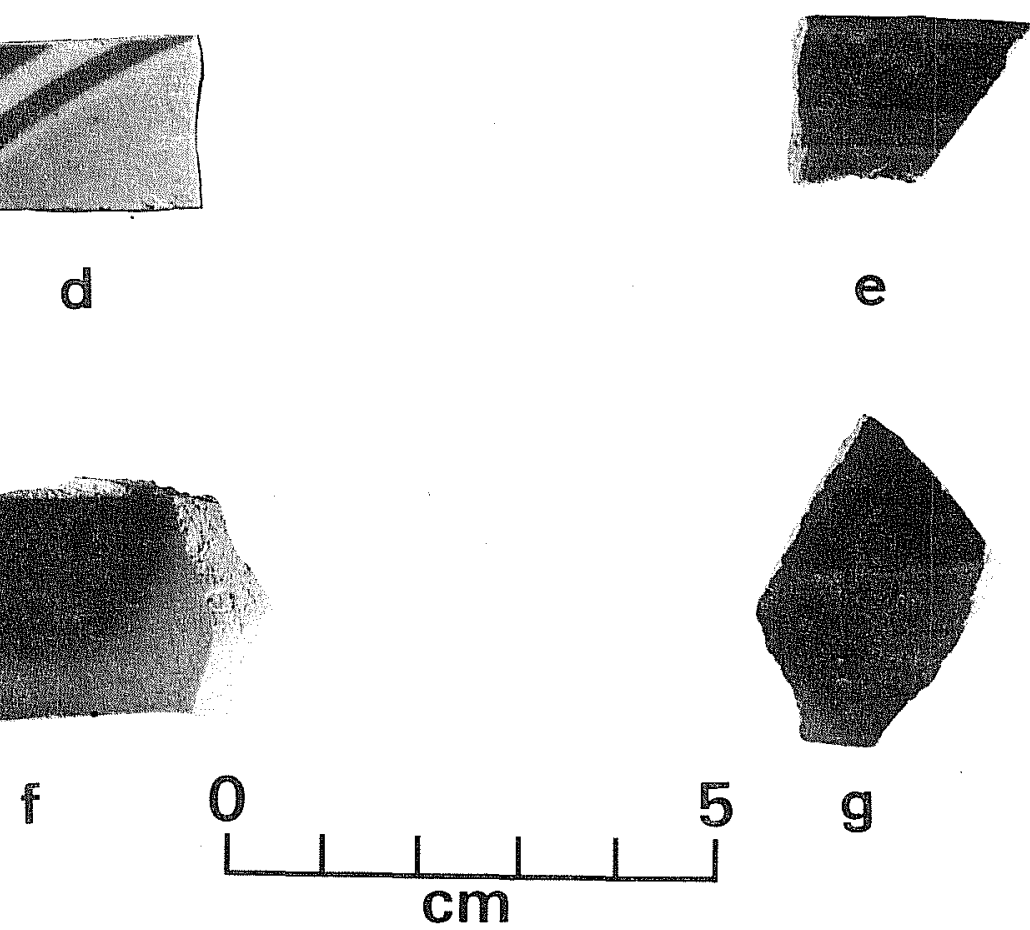

e
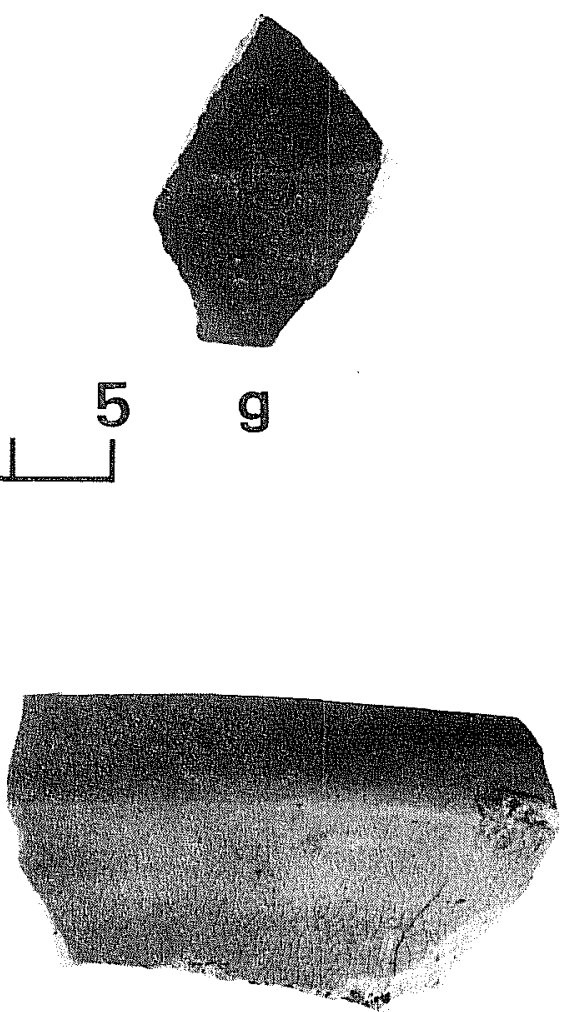

h

Figure 22. Historic Ceramics. a, edgeware, blue on white; b, sponged ware, blue on white; $c$, transfer printed ware, blue on white; d, mocha or banded ware, blue on white; e, red paste, lead glazed, brown on orange ware; f, flown blue ware; g, red paste, lead glazed, brown ware; $h$, hand-painted floral design, black, red, green and blue on white; $i$, yellow ware. 

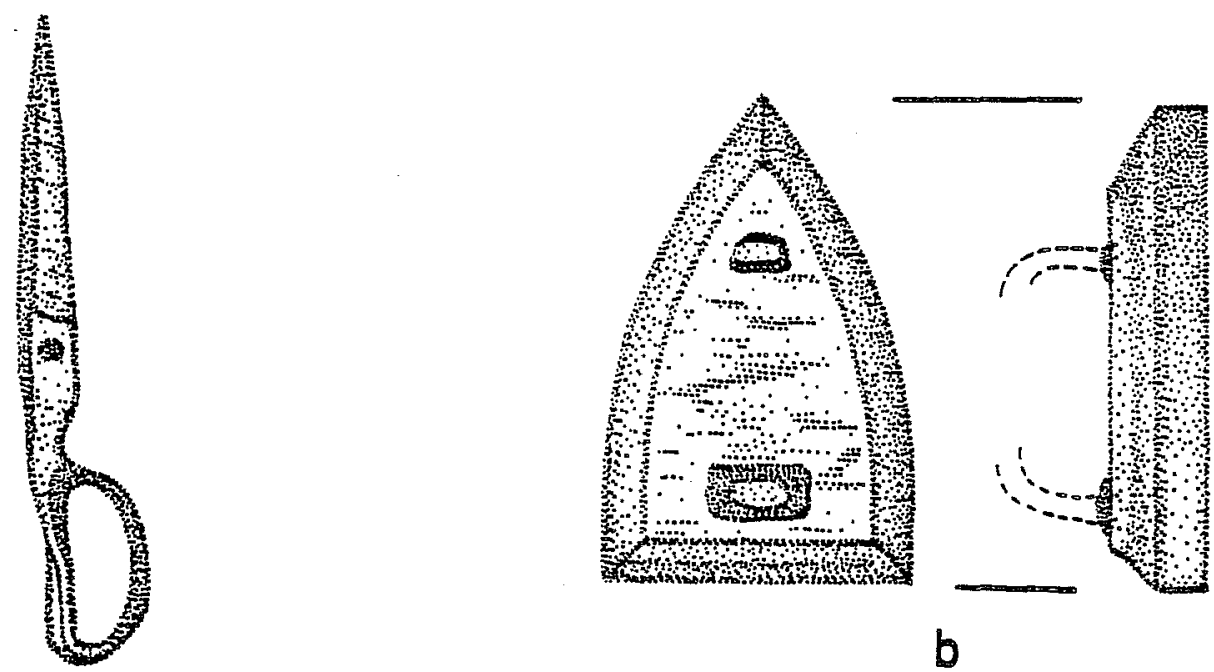

b

a
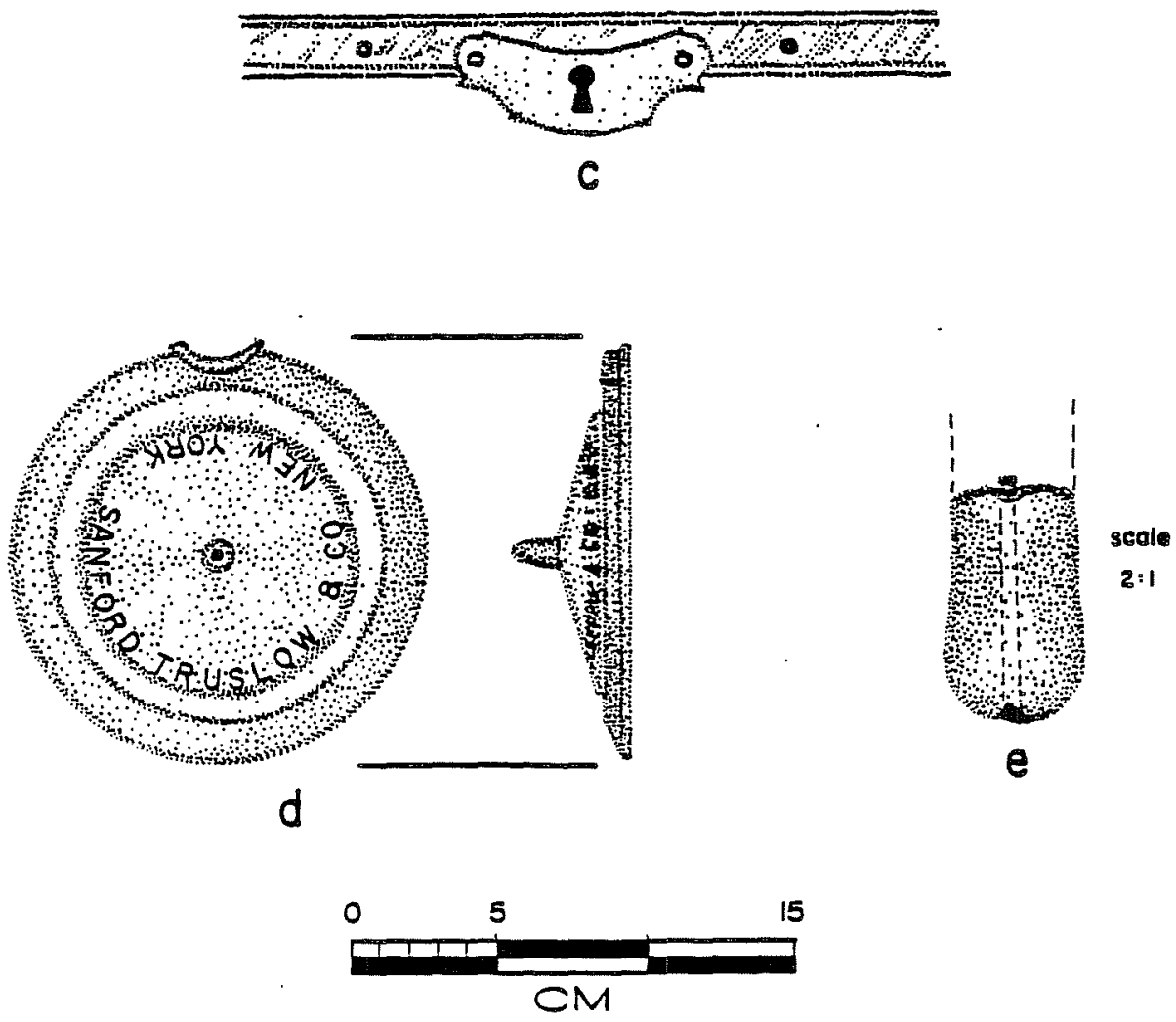

Figure 23. Household Items. a, scissors fragment; b, flat iron; c, brass trunk lock plate; $d$, cast iron kettle cover; e, pewter spoon handle. 
key may have been used in a recovered trunk lock (Fig. 23,c). Two small pieces of slate could be from a writing tablet. A fragment of a simple milk. glass lamp globe indicates the type of artificial household lighting used at site 41 LK 202. Charcoal probably represents wood stove and/or fireplace clean-out.

Harness Trappings and Agricultural Equipment (16 specimens, Fig. 24)

The 19th century agrarian nature of the occupation of site 41 LK 202 is reflected by harness trappings, a horse shoe and horse shoe nails, an iron reinforcing band (probably for a singletree $5.0 \mathrm{~cm}$ in diameter), and a section of a heavy ( $3.5 \mathrm{~mm}$ thick) saw blade, probably part of a horse-drawn mower (Fig. 24,c). Three fence staples probably post-date the household occupation of site 41 LK 202 and represent 1ate 19th century or 20th century fence construction across the site area. Harness trappings include harness buckles (Fig. 24,b), a harness ring, chain links (probably from trace chains), a nickle bridle rosette (Fig. $24, a)$, and a broken iron four-ring bridle bit (Fig. 24,d).

Personal Items (34 specimens; Fig. 25)

The clothing, the habits and other personal aspects of the occupants of sites 41 LK 202 and 41 LK $31 / 32$ are reflected by clothing fasteners, tobacco pipe and pipe stem fragments, beads, an iron spur fragment (Fig. 25,d), a porcelain do 11 leg fragment, a harmonica reed fragment, a sma11, thin decorative brass pocket $\mathrm{knife}$ escutcheon, and a tooth from a comb (Table 12).

Clothing fasteners include metal, glass, porcelain and shell shirt and/or blouse and shoe buttons (Fig. $25, h, i$ ), a brass hook-and-eye, a small brass rivet, buckle fragments and a fancy brass suspender buckle (Fig. 25,e). One metal button (recovered from site $41 \mathrm{LK} \mathrm{31/32)}$ is a U.S. Army button (Fig. 25,g) produced for enlisted men between 1855 and the 1870 s by the Scovil1 Company (Brinckerhoff 1965:74). One multifaceted glass bead (Fig. 25,f) is translucent red with a small brass eye and may have been used as a decorative button. The other is an opaque, dark brown, spherical glass bead, $8.5 \mathrm{~mm}$ in diameter.

Two basal fragments of unglazed clay tobacco pipes (Fig. 25,a,c) are similar to pipes produced in Pamplin, Virginia during the 19th century (Hamilton and Hamilton 1972:Plates 17,M and 22, $\mathrm{AH}$ ). A thin rim sherd of clear glazed white paste earthenware, burned on the interior, appears to be from a pipe bowl with an interior diameter of approximately $2.5 \mathrm{~cm}$. A white clay pipe stem fragment (Fig. 25,b), $6.3 \mathrm{~cm}$ long, is oval in cross section and tapers gradually from a thickness of $8 \times 11 \mathrm{~mm}$ to $6 \times 9 \mathrm{~mm}$ at the mouth piece.

The rubber or celluloid tooth of a large comb conceivably could date to the Tate 19th century, but probably represents 20 th century use (or even the archaeological investigation) of site 41 LK 202. 


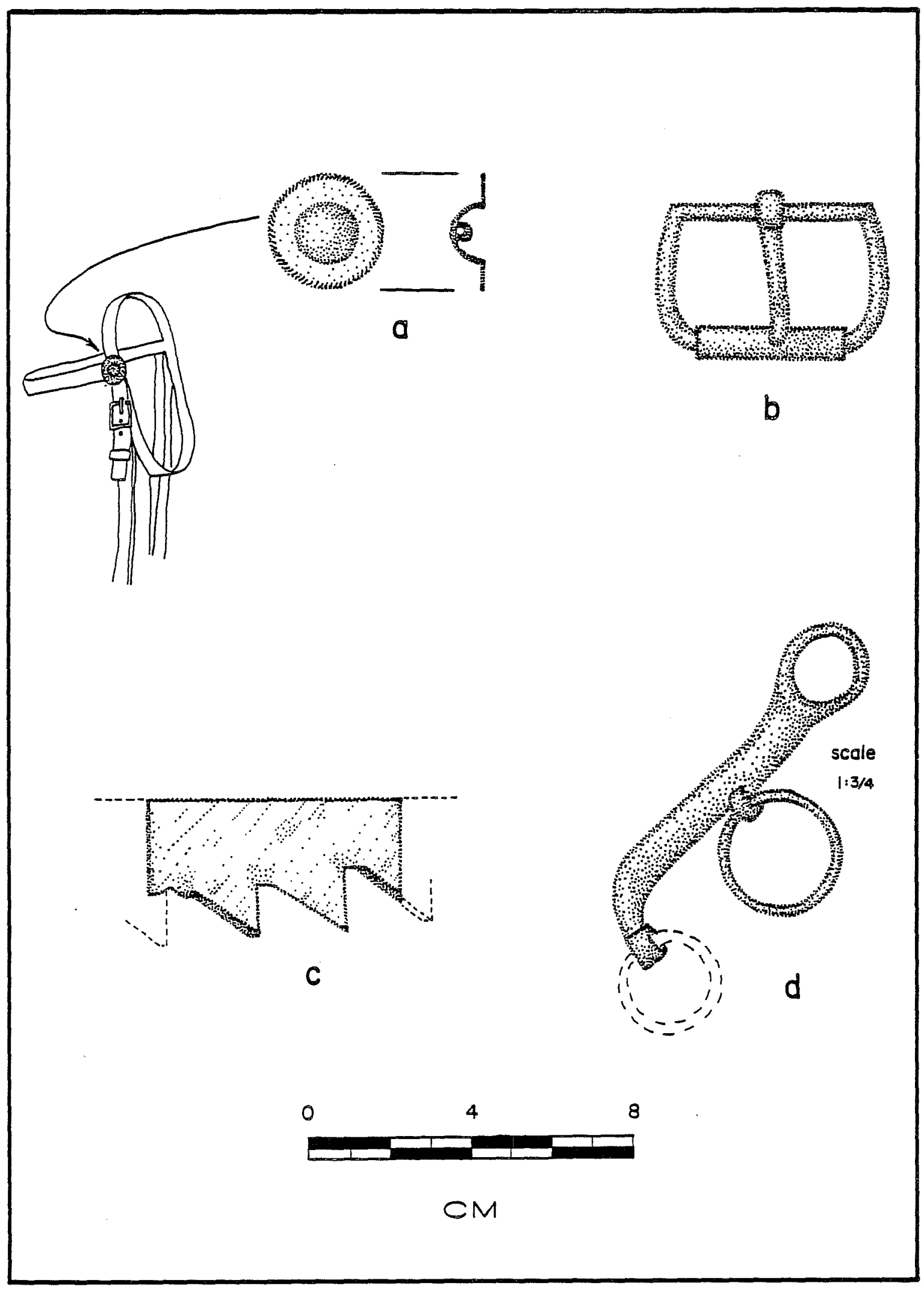

Figure 24. Harness Trappings and Mower Blade Fragment. a, nickle bridle rosette; $b$, cinch buckle; $c$, mower blade fragment; $d$, ring bit fragment. 

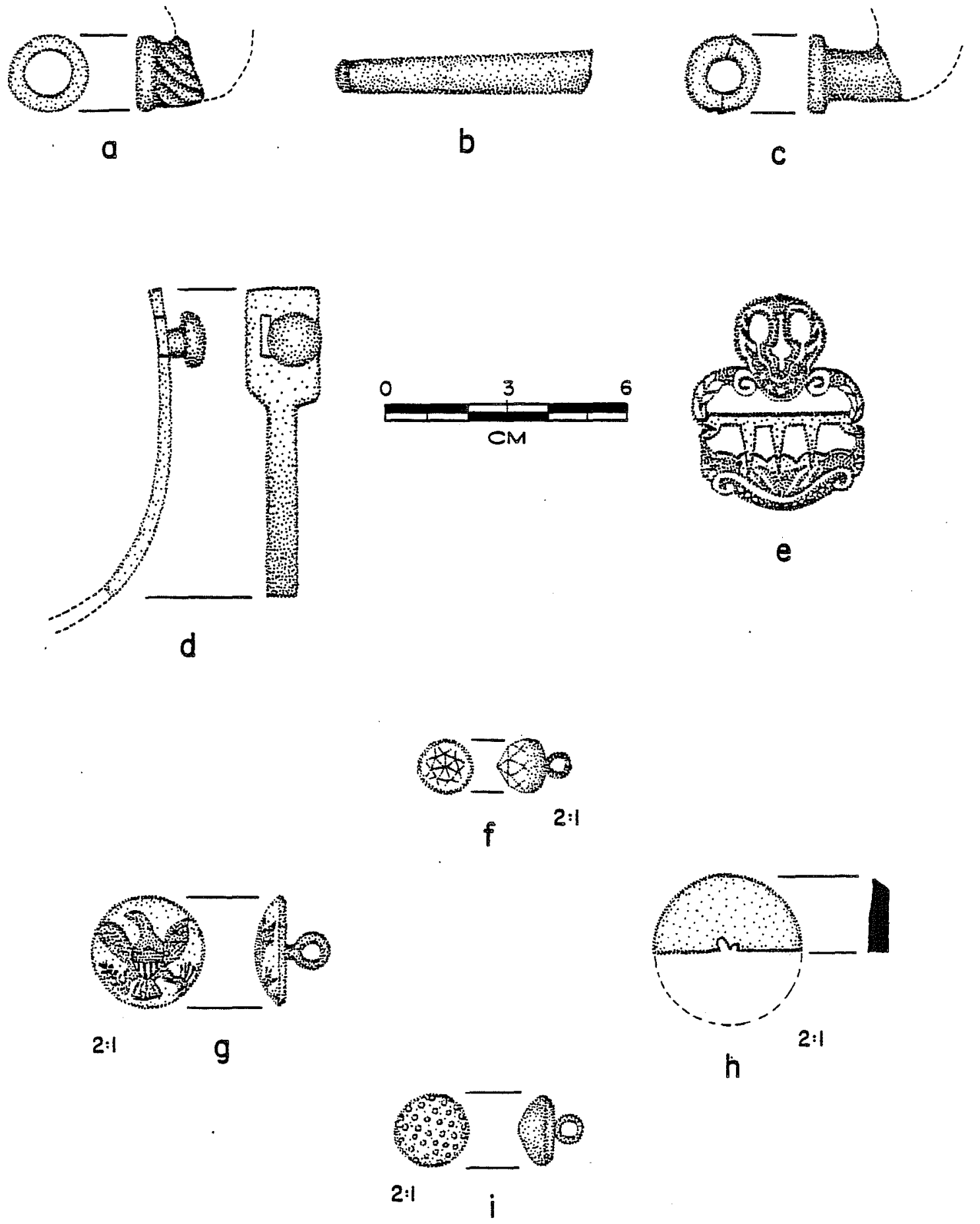

Figure 25. Personal Items. a, clay pipe fragment; b, clay pipe stem fragment; $c$, clay pipe fragment; $d$, spur fragment; e, suspender buckle; $f$, red multifaceted glass button (or bead); g, Scovil1 \& Co. U.S. Army button; $h$, black glass button fragment; $i$, brass shoe button. 
Firearm-Related Items (21 specimens; Fig. 26)

The use of at least seven different rifles and pistols is indicated by 12 centerfire and rimfire cartridges (Fig. 26,b), four artifacts of lead, a gun part and a pistol flint (Fig. 26,d). Revolvers, muzzle-loaded and breech-loaded pistols and rifles are represented. All cartridges date from the mid-to late19th century (Logan 1959:68-69, 136).

Two threaded zinc screw-on caps (Fig. 26,a) for zinc or cardboard black powder containers bear the trademark "HAZARDS POWDER" and probabTy date to the mid19th century (Sam Nesmith, personal communication, December 1978). A rectanguloid flake of chert, plano-convex in cross section (11 mm thick), is unifacially beveled and may have been used as a gunflint, a strike-o-light (Fig. 26,C), or some other tool form.

\section{Miscellaneous and Unidentifiable Metal (91 specimens)}

An assortment of iron and tin, copper and/or brass probably represents a variety of implements (Table 12). A metal arrow point (Fig. 20, C) is similar in shape to metal projectile points reported from south Texas (Mitchell 1974). It is $4.3 \mathrm{~cm}$ long, $1.7 \mathrm{~cm}$ wide at the shoulders, $0.7 \mathrm{~cm}$ wide at the intersection of the stem and the blade, and $2 \mathrm{~mm}$ thick. The edges of the slightly expanding stem have hatchurelike cuts, probably added as a hafting modification.

Metal straps probably were used in building, barrel, and trunk construction. Iron wire could have been employed as construction material or bucket bales.

A heavy tool or piece of fireplace hardware (Fig. 20,a) was wrought from a length of rectangular iron bar $(25.6 \mathrm{~cm}$ long, $2.3 \mathrm{~cm}$ wide and $1.1 \mathrm{~cm}$ thick). One end was bent-over to form a projection, like the head of a spike or a chisel. The opposite end of the bar was flattened, giving it a spatulate shape ( $15.5 \mathrm{~cm}$ long, $4.0 \mathrm{~cm}$ wide, and $6 \mathrm{~mm}$ thick). Although it may have been used as some sort of tool, this hand-forged artifact could have been wedged between the stones of a fireplace to form a support for a grate or some other kind of fireplace furniture.

An iron wing bolt ( $7 \mathrm{~mm}$ in diameter at the shank) probably was an adjustment screw for a household, construction or agricultural implement (Fig. 20,e). A rolled and pointed tin cone (Fig. 20,f) and an assortment of miscellaneous scraps of iron and tin are not identifiable as to function.

Summary and Interpretations

Archaeology at sites 41 LK 202 and the historic component of 41 LK $31 / 32$ provides data on historic household occupations at three structures (Fig. 27). Viewed as a unit, occupation of this complex of households began during the 1850 s and lasted until the 1880s, judging from the chronological association of food-, medicine-, and beverage-related materials, household garbage, and firearm-related items. A metal arrow point found in the vicinity of site 41 LK 31/32 may pre-date this occupation, but could be contemporaneous with 


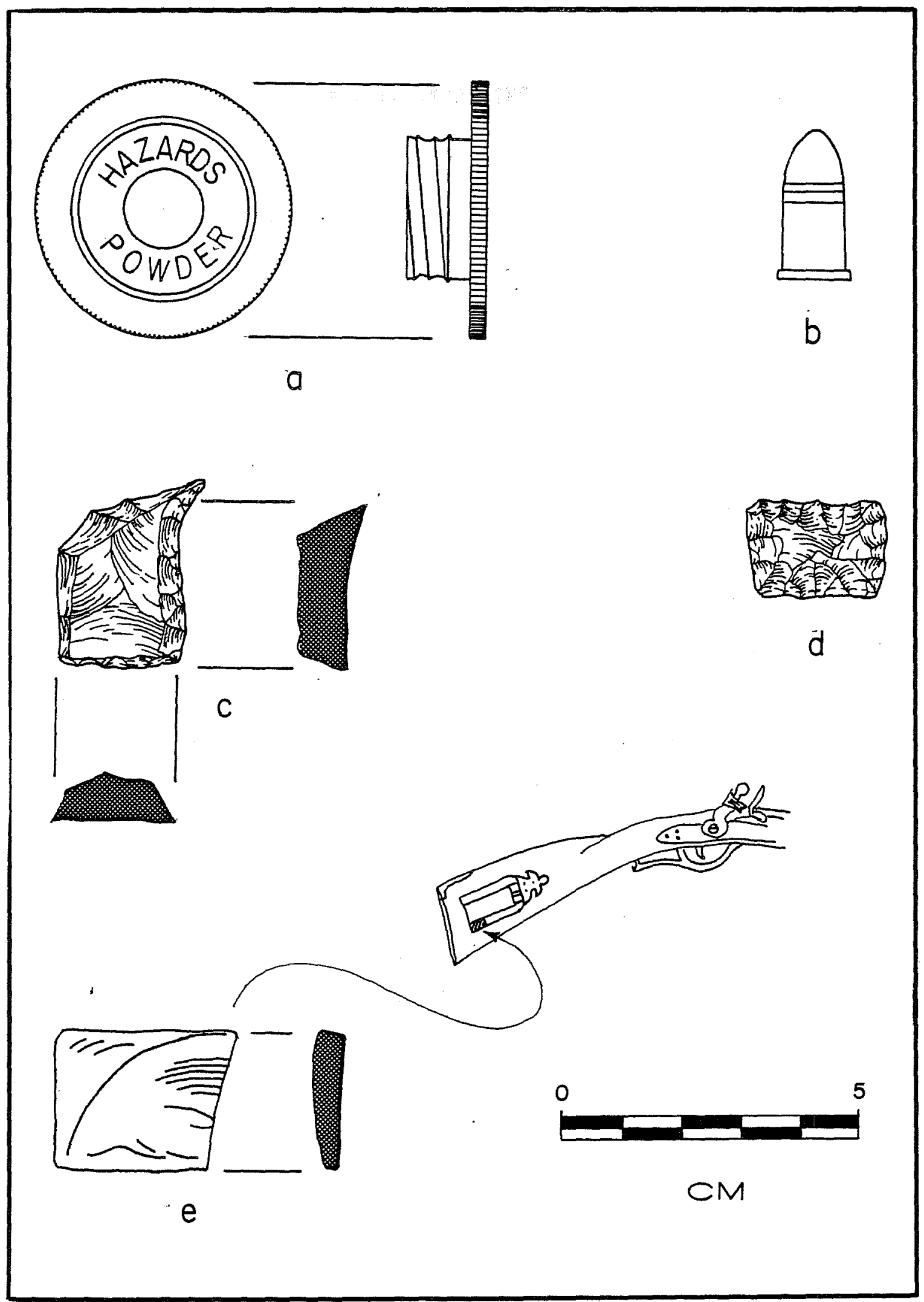

Figure 26. Firearm-Related Items. a, zinc powder container cover; b, .41 caliber rimfire short cartridge for Remington Derringer; $c$, possible gun flint or strike-o-light; $d$, pistol flint; e, brass patch box cover. 


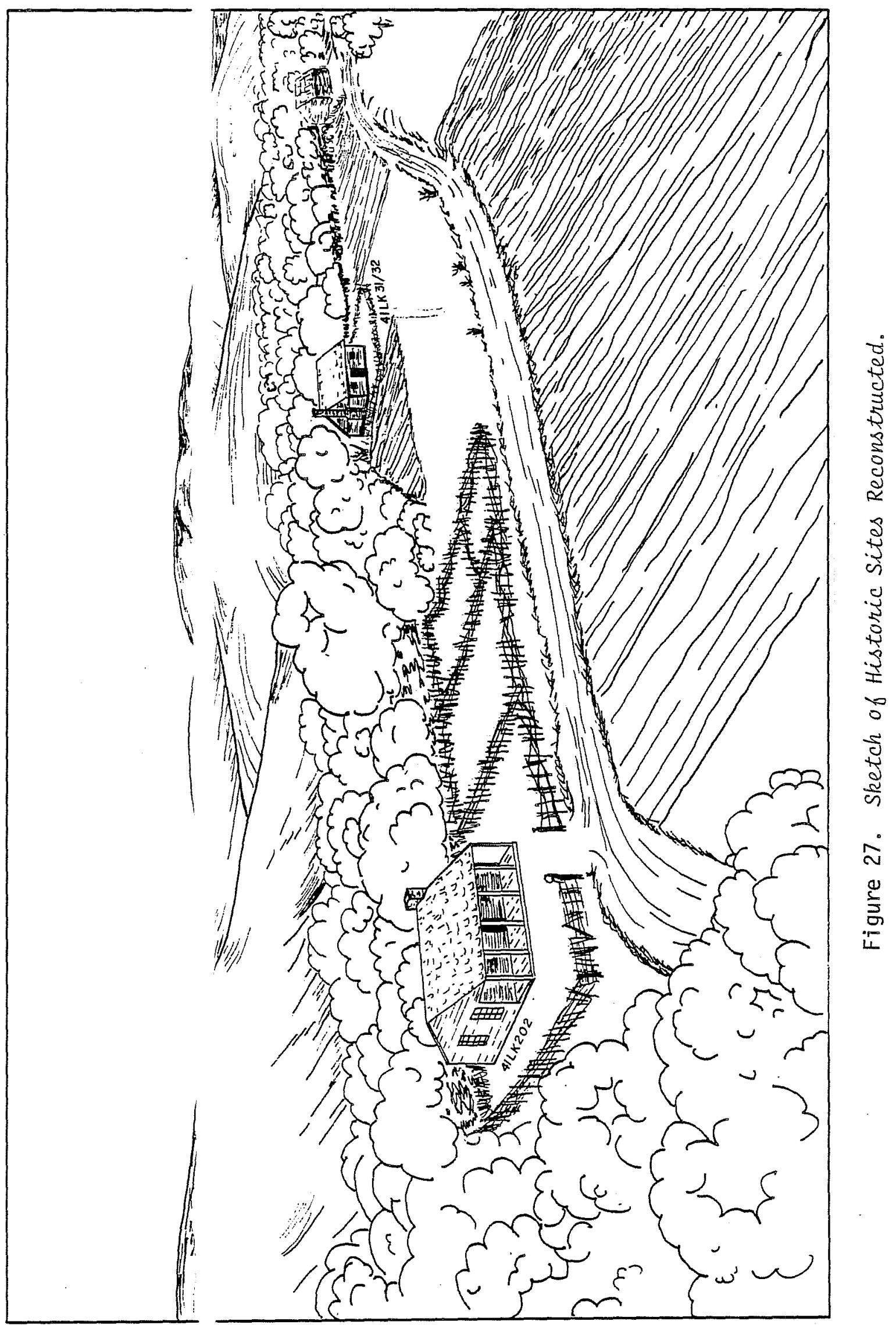


it. Some construction materials (wire nails) and agricultural equipment (fence staples) probably reflect late 19th century fence construction across the occupation area and posssibly early 20th century renovation of the structure at site 41 LK 202, perhaps in maintenance of the ruins as a hay barn. One personal item (a tooth from a comb) probably indicates a 20th century visit to this site.

Taken individual7y, sites 41 LK 202, 41 LK 31/32, and evidence of a household occupation to the northeast apparently are different from one another in length of occupation, nature of building construction, and possibly ethnic affiliation. Everything about site 41 LK 202 reflects a continuous household occupation during the period from the late 1850s to about 1880. The large quantity of square cut nails, other building hardware, and windowpane glass represents a relatively substantial frame structure. The high frequency of occurrence of sherds from alcoholic beverage bottles, the types of clothing represented by personal items, and the wide variety of firearm-related items suggest that the site was occupied by adult male and female Anglo-Americans. A porcelain doll part is the only evidence to suggest that children may have lived there.

A considerably smaller quantity of cultural material was recovered from site $41 \mathrm{LK} 31 / 32$, even though a large area was excavated. The relatively smal1 sample size can be explained partly by the short time span during which the site was occupied. Decorated British-made ceramic sherds comprise about $27 \%$ of the sample of white paste earthenware recovered from-site $41 \mathrm{LK} 31 / 32$ (compared to about 10\% from site 41 LK 202), suggesting that the structure was occupied primarily during the late 1850 s and the 1860s. Brown bottle glass, that became common in the 1870s, was not found at site $41 \mathrm{LK} 31 / 32$.

A7 though wrought iron and square cut nails from site 41 LK $31 / 32$ are of the same sizes as those recovered from site 41 LK 202, they are much fewer in number, suggesting that the walls of the structure were not of frame construction. The lack of other forms of building hardware, such as hinges, screws, and door latches, and the extremely limited sample of windowpane glass (one sherd which could be from a mirror) gives the impression that the building at site 41 LK 31/32 was less permanent than the frame house at site 41 LK 202. Perhaps it was a simple jacal or picket structure with a shingle or thatched roof.

This building functioned as a dwelling, judging from the assortment of household garbage, food-, medicine-, and beverage-related materials, and personal items recovered. However, no harness trappings or agricultural equipment were found at site $41 \mathrm{LK} 31 / 32$, suggesting that such equipment was stored or used somewhere else. Firearm-related items seem to represent rather primitive weapons and/or hunting implements, although they may have been sophisticated enough for the years preceding the Civil War. It seems quite possible that this household structure at site 41 LK $31 / 32$ was a tenement built to house labor for the farm and ranch headquartered at site 41 LK 202.

It is impossible to make credible interpretations of the duration of occupation, nature of construction or ethnic affiliation pertaining to the cluster of artifacts found about $150 \mathrm{~m}$ northeast of the structural remains at site $41 \mathrm{LK} \mathrm{31/32.} \mathrm{Although} \mathrm{the} \mathrm{artifacts} \mathrm{are} \mathrm{indicative} \mathrm{of} \mathrm{household} \mathrm{occupation}$ 
contemporaneous with the occupation of sites 47 LK 202 and 41 LK 37/32, and scattered sandstone blocks, noted during field work, probably are evidence of a structure, no intensive surface inspection or controlled excavations were conducted in this area.

The material culture from the occupation area composed of sites 41 LK 202 and 41 LK 31/32 are representative of a mid-19th century frontier settlement. The occupants maintained households which were self-sufficient, to a great extent, and to a varying degree dependent upon established communities several leagues away. Archaeological materials reflect a subsistence based on ranching and probably some farming, supplemented by hunting. The settlers consumed foods and used other materials and equipment produced on the homestead, extracted from the countryside and imported from trade centers on the Texas coastal plain, in south central Texas, and possibly on the Rio Grande. Characteristic of their subsistence were large quantities of domesticated and wild animal foods, a sufficient supply of bitters, schnapps and other spirits, medicines and an extensive arsenal of firearms.

Summarizing the documentary research into the ownership and occupation of sites 41 LK $31 / 32$ and 41 LK 202, it seems that John and Elizabeth King, and possibly their slaves, were the first occupants. It is possible that Thomas King constructed and occupied one of the houses, although his land was acquired by John and Elizabeth King apparently by 1880 , when they sold their property. There also is a slight possibility that cattlemen Slaughter and Pelham occupied the King property temporarily before the Civil War. After 1880, sites 41 LK 31/32 and 41 LK 202 probably were not occupied, and by 1897 the houses had likely fallen into ruin.

Sites 41 LK $31 / 32$ and 41 LK 202 should then be considered historically significant from at least two viewpoints: the cultural and genealogical background of their occupants, and the meaning of this occupation in the lower Frio River valley within the historical context of mid- to late-19th century south Texas. Who were the Kings? It does not seem likely that slave owner John G. King was related to Pennsylvania Presbyterian Richard King who began the King Ranch of the lower coastal plain (Fehrenbach 1968:288-289). Certainly there were a number of Kings in Anglo-American Texas (McDowe11 1967).

It can be suggested that John and Elizabeth King moved to Live Oak County from an established community of Southern planters and yeoman farmers who settled Austin's and DeWitt's colonies during the 1820s and 1830s. In 1836, a William P. King and his brother, John G. King, responded to Travis' request for relief at the Alamo. In 1838, another John G. King, probably the father of the two young men, claimed the estate of William P. King (Webb Vol. 1 1952: 960). Apparent7y, the younger John G. King actualiy did not go to the Alamo. Instead, a substitute went in his place, as was common practice in those days (Catherine McDowe11, Librarian, Daughters of the Republic of Texas, personal communication). It seems quite possible that the John $G$. King who, with his wife, acquired land on the M. Killely Survey of Live Oak County in 1857 and died about 1890 was the brother of William P. King, who died at the Alamo. Thomas King may have been John G. King's brother, or perhaps his son. 
Assuming that sites 41 LK $31 / 32$ and 41 LK 202 were occupied by descendents of Southern planters or yeoman farmers, this occupation fits well into the general pattern of frontier settlement in Texas suggested by Fehrenbach (1968: 297):

$$
\begin{aligned}
& \text {. hunter-trader-trapper on the far frontier; hunter- } \\
& \text { farmer behind him through a large yeoman belt; then the } \\
& \text { planters forging their own kind of civilized existence in } \\
& \text { the rear. The towns, most of which were minor ports or } \\
& \text { river stations or mere crossroads settlements, supported } \\
& \text { this settlement when and where they could. }
\end{aligned}
$$

About 5.5 miles to the east of the King's place was the growing community of 0akville. Some 12 miles to the west, up the Frio River, were the cattlemen of Yarbrough Bend. Further west was Dog Town and the Laredo/San Antonio road and the vast expanse of unsettled frontier.

The King's occupation of the lower Frio River valley is an example of the development of the south Texas cattle industry on an open range. Their agreement with Slaughter and Pelham reflects the time, before the range was fenced off in the early 1880s (ibid.:567), when people leased cattle instead of grassTand.

What happened at the King place from 1857 to 1880 has been obscured by the effects of time. Apparently the King family did not survive in Live Oak County after 1913 to hand down the legacy of John and Elizabeth King. What happened at the King place is preserved only in the structural evidence and patterning of household refuse which form the archaeological context of 41 LK $31 / 32$ and 41 LK 202. 


\section{REFERENCES CITED}

Anonymous

1954 A Radiocarbon Date on the Falcon Focus. Bulletin of the Texas Archeological Society $25: 565$.

Antevs, E.

1955 Geologic Climatic Dating in the West. American Antiquity 20:317-335.

Baker, V. R. and M. M. Penteado-Orellana

1977 Adjustment to Quaternary Climatic Change by the Colorado River in Central Texas. Journal of Geology $85(4): 395-422$.

Bean, L. J.

1972 Mukat's People, the Cahuilla Indians of Southern California. University of California Press, Berkeley.

Bicchieri, E. G. (ed.)

1972 Hunters and Gatherers Today. Holt, Rinehart and Winston, New York.

Blair, W. F.

1950 The Biotic Provinces of Texas. The Texas Journal of Science 2(1):93-117.

Brinckerhoff, S. B.

1965 Metal Uniform Insignia of the U.S. Army in the Southwest, 18461902. The Journal of Arizona History Summer:71-92.

Bryant, V. M., Jr.

1975 Pollen as an Indicator of Prehistoric Diets in Coahuila, Mexico. Bulletin of the Texas Archeological Society 46:87-106.

1978 Palynology: A Useful Method for Determining Paleoenvironment. Texas Journal of Science 30(1):25-42.

Bryant, V. M., Jr. and H. J. Shafer

1977 The Late Quaternary Paleoenvironment of Texas: A Model for the Archeologist. Bulletin of the Texas Archeological Society 48: 1-25. 
Bunker, R. C.

1982 The Geomorphic Framework of Human Occupation in the Frio River Valley, Choke Canyon Dam Reservoir, Live Oak and McMullen Counties, Texas. In Archaeological Investigations at Choke Canyon Reservoir, South Texas: The Phase I Findings, by G.D. Hal1, S. L. Black, and C. Graves: Appendix II. Center for Archaeological Research, The University of Texas at San Antonio, Choke Canyon Series 5.

Campbe1 1, T. N.

1975a The Payaya Indians of Texas. Southern Texas Archaeological Association, Special Publication 1, San Antonio.

1975b Personal communication reported in 1975. In Some Aspects of Late Prehistoric and Protohistoric Archaeology in Southern Texas, by T.R. Hester and T. C. Hill, Jr.:2.1. Center for Archaeological Research. The University of Texas at San Antonio, Special Report 1 .

Campbe11, T. N. and T. J. Campbel1

1981 Historic Indian Groups of the Choke Canyon Reservoir and Surrounding Area, Southern Texas. Center for Archaeological Research, The University of Texas at San Antonio, Choke Canyon Series 1 .

Cook, S. F.

1946 A Reconsideration of Shell Mounds with Respect to Population and Nutrition. American Antiquity 12:51-53.

Davis, E. M. and J.E. Corbin

1967 Archeological Investigations at Washington-on-the-Brazos State Park. State Building Commission Archeological Program Report 5. Austin.

Di11ehay, T. D.

1974 Late Quaternary Bison Population Changes on the Southern Plains. Plains Anthropologist 19(65):180-196.

Dobie, J.F.

1941 The Longhorns. Grosset and Dunlap, New York.

Fawcett, W. B., Jr.

1977 An Examination of Prehistoric Variability in Southern Texas. Unpublished manuscript on file, Texas Archeological Survey, Austin. 
Fawcett (continued)

1979 Phase III Archeological Research Within Palmetto Bend Reservoir, Jackson County, Texas. Unpublished manuscript on file, Texas Archeological Survey, Austin.

Fehrenbach, T. R.

1968 Lone Star: A History of Texas and Texans. Macmillan Company, Toronto.

Fontana, B. L. and J. C. Greenleaf

1962 Johnny Ward's Ranch: A Study in Historical Archaeology. The Kiva 28(1-2):1-115.

Fox, A.A.

1974 Lead Glazed Wares. In Mission Rosario Archeological Investigations 1973, by K. Gi1more:55-59. Texas Parks and Wildlife Department Archeological Report 14. Austin.

Fox, D. E.

1979 Archaeological Investigations of Two Prehistoric Sites on the Coleto Creek Drainage, Goliad County, Texas. Center for Archaeological Research. The University of Texas at San Antonio, Archaeological Survey Report 69.

Godden, G. A.

1964 Encyclopedia of British Pottery and Porcelain Marks. Bonanza Books, New York.

1971 The Illustrated Guide to Mason's Patent Ironstone China. Praeger Publishers, New York.

Gunn, J. and R. MahuTa (eds.)

1977 Hop Hi11; Culture and Climatic Change in Central Texas. Center for Archaeological Research, The University of Texas at San Antonio, Special Report 5.

Ha11, G. D., S. L. Black, and C. Graves

1982 Archaeological Investigations at Choke Canyon Reservoir, South Texas: The Phase I Findings. Center for Archaeological Research, The University of Texas at San Antonio, Choke Canyon Series 5. 
Ha11, G. D., K. M. Brown and D. R. Potter

1982 Excavations at 41 LK 67, A Prehistoric Site in the Choke Canyon Reservoir, South Texas. Center for Archaeological Research, The University of Texas at San Antonio, Choke Canyon Series 7.

Hami 1 ton, H. W. and J. T. Hamilton

1972 Clay Pipes from Pamplin. The Missouri Archaeologist 34(1-2): $1-47$.

Hester, T. R.

1971 Archeological Investigations at the La Jita Site, Uvalde County, Texas. Bulletin of the Texas Archeological Society 42:51-148.

1972 Review of Mukat's People, the Cahuilla Indians of Southern California. In California Historical Quarterly LI(3), by L. J.Bean:284-286.

1975 Late Prehistoric Culture Patterns Along the Lower Rio Grande of Texas. Bulletin of the Texas Archeological Society 46:107-125.

1977 Hunters and Gatherers of the Rio Grande Plain and the Lower Coast of Texas. Center for Archaeological Research. The University of Texas at San Antonio.

1980 Digging into South Texas Prehistory. Corona Publishing Company, San Antonio.

Hester, T. R. and T. C. Hi11, Jr.

1975 Some Aspects of Late Prehistoric and Protohistoric Archaeology in Southern Texas. Center for Archaeological Research. The University of Texas at San Antonio, Special Report 1.

Hi11, T. C., Jr., J. B. Holdsworth, and T. R. Hester

1972 Yucca Exploitation: A Contemporary Account from the Rio Grande Plain. La Tierra 4(1):19-21. San Antonio.

Howard, C. D.

1973 A Study of the Clear Fork Gouge. Bulletin of the Texas Archeological Society 44:51-60.

Inglis, J. M.

1964 A History of Vegetation on the Rio Grande Plain. Texas Parks and Wildlife Department, Bulletin 45. Austin. 
Johnson, E. H.

1931 The Natural Regions of Texas. Bureau of Business Research, Research Monograph 18. Austin.

Lee, R. B.

1979 The :Kung: Men, women, and work in a Foraging Society.

Cambridge University Press, Cambridge.

Lee, R. B. and I. DeVore

1968 Man, the Hunter. Aldine Press, Chicago.

Lewis, R. 0 .

1978 Use of Opal-Phytoliths in the Paleoenvironmental Reconstruction at the Hudson-Meng Site. In The Hudson-Meng Site: An Alberta Bison Kill in the Nebraska High Plains, by L. D. Agenbroad: 211-216. The University Press of America, Washington, D.C.

Live Oak County, Texas

Abstract and Survey Records.

Deed Records.

Probate Minutes.

Logan, H. C.

1959 Cartridges: A Pictorial Digest of Small Arms Ammunition. Bonanza Books, New York.

Looney, M. R. and V. R. Baker

1977 Late Quaternary Geomorphic Evolution of the Colorado River, Inner Texas Coastal Plain. Transactions of the Gulf Coast Associations of Geological Societies, 27th Annual Meeting XXVII : 323-332.

Lynn, W. D., D. E. Fox, and N. O'Malley

1977 Cultural Resources Survey of Choke Canyon Reservoir, Live Oak and McMullen Counties, Texas. Texas Historical Commission, office of the State Archeologist, Archeological Survey Report 20. Austin.

Mallouf, R. J., D. E. Fox, and A. K. Briggs

1973 An Assessment of the Cultural Resources of Paimetto Bend Reservoir, Jackson County, Texas. Texas Historical Commission and Texas Water Development Board, Archeological Survey Report 11. Austin. 
McDowe11, C. W. (ed.)

1967 Now You Hear My Horn: The Journal of James Wilson Nichols, 1820-1887. The University of Texas Press, Austin.

Mitche11, J. L.

1974 Notes on Metal Projectile Points from Southern Texas. Journal of South Texas 1:47-51. Corpus Christi.

Munsey, C.

1970 The Illustrated Guide to Collecting Bottles. Hawthorn Books, New York.

Murray, H. D.

1982 An Analysis of Unionids (Freshwater Mussels) Recovered in Phase I

Archaeological Investigations at Choke Canyon Reservoir. In Archaeological Investigations at Choke Canyon Reservoir, South Texas: The Phase I Findings, by G. D. Hal1, S. L. Black, and C. Graves: Appendix VI. Center for Archaeological Research, The University of Texas at San Antonio, Choke Canyon Series 5.

Newcomb, W. W., Jr.

1961 The Indians of Texas. The University of Texas Press, Austin.

Parmalee, P. and W. E. K1 ippel

1974 Freshwater Mussels as a Prehistoric Food Resource. American Antiquity 39(3):427-434.

Ralph, E. K., N. H. Michael, and M. C. Han

1973 Radiocarbon Dates and Reality. MASCA Newsletter 9(1).

Ray, C. N.

1941 Various Types of Clear Fork Gouges. Bulletin of the Texas Archeological and Paleontological Society 13:152-162.

Raycraft, D. and C. Raycraft

1975 American Country Pottery. Wallace-Homestead Book Company, Des Moines.

Roberson, W. R.

1974 The Carrington-Covert House: Archeological Investigation of a 19th-Century Residence in Austin, Texas. Texas Historical Commission, Office of the State Archeologist Report 25, Austin. 
Robinson, R. L.

ms. The Study of Biosilica: Reconstructing the Paleoenvironment of the Central Coastal Plain of Texas. Center for Archaeological Research. The University of Texas at San Antonio, Special Report 7. In preparation.

Ruecking, F., Jr.

1953 The Economic System of the Coahuiltecans of Southern Texas and Northeastern Mexico. Texas Journal of Science 6(3):480-497.

Sellards, E. H., W. S. Adkins, and F. B. Plummer

1975 The Geology of Texas, Volume 1: Stratigraphy. Bureau of Economic Geology, The University of Texas Bulletin 3232, Austin.

Shafer, H. J. and E. P. Baxter

1975 An Archeological Survey of the Lignite Project, Atascosa and McMullen Counties, Texas. Texas AEM University, Anthropology Laboratory Report 7, College Station.

Sitberbauer, G. B.

1972 The G/Wi Bushmen. In Hunters and Gatherers Today, ed., E. G. Bicchieri:271-326. Holt, Rinehart and Winston, New York.

Sjoberg, A.

1976 Phosphate Analysis of Anthropic Soils. Journal of Field Archaeology 3:447-454.

Switzer, R. R.

1974 The Bertrand Bottles: A Study of 19th Century Glass and Ceramic Containers. National Park Service, U.S. Department of the Interior. Washington, D.C.

Suhm, D. A. and E. B. Jelks

1962 Handbook of Texas Archeology: Type Descriptions. Texas Archeological Society Special Publication 1 and Texas Memorial Museum Bulletin 4. Austin.

Thoms, A. V., J. L. Montgomery, and A. W. Portnoy

1981 An Archaeological Survey of a Portion of the Choke Canyon Reservoir Area in McMullen and Live Oak Counties, Texas. Center for Archaeological Research. The University of Texas at San Antonio, Choke Canyon Series 3. 
U.S. Department of the Interior

1975 Final Environmental Impact Statement, Nueces River Project, Choke Canyon Dam and Reservoir Site, Texas. Bureau of Reclamation, Southwest Region, Amaril10.

Watson, R.

1965 Bitters Bottles. Thomas Nelson and Sons, New York.

Webb, W. P. (ed.)

1952 The Handbook of Texas. Volumes I and II. Texas State Historical Association, Austin.

Weeks, A. W.

1933 Lissie, Reynosa and Upland Terrace Deposits of Coastal Plain of Texas Between Brazos River and Rio Grande. Bulletin of the American Association of Petroleum Geologists 17(5):453-487.

Wing, E. S. and A. B. Brown

1979 Paleonutrition; Prehistoric Foodways. Academic Press, New York. 


\section{APPENDIX I}

\section{SCOPE OF WORK}

Test excavation by the University of Texas at San Antonio (UTSA) has recovered significant data from 41 LK $31 / 32$ and 41 LK 202 and demonstrated the likelihood of these archaeological sites containing additional significant data. The preliminary results of the evaluation of these sites are given in the attached UTSA report.

The mitigation of impact program to be conducted at 41 LK 31/32 and 41 LK 202 shall include recovery of data through excavation, analysis of that data, and production of an investigative report detailing the results of the excavation and analysis.

Work to accomplish this program requires the following:

a. Formulation of a site specific research design addressing at least the following problems:

(1) Understanding of the lifeways of the populations whose presence is indicated at the sites. sites.

(2) Determination of specific behavior patterns which occurred at the

(3) Recovery of data relevant to the chronology of the sites.

(4) Recovery of data relevant to previous area research.

b. Commitment to undertake field work involving:

(1) Manual excavation of an area sufficient in extent and depth to satisfy requirements of research design. All major artifacts and elements of occupational features shall be left in situ until photographed and plotted on measured plan maps. Carbon samples for radiocarbon assay shall be collected. Matrix samples for soil, pollen, and other analyses shall be collected from each excavation level and/or "living surface."

(2) The extent of mechanical excavation required to satisfy requirements of the research design for the deeply stratified cultural deposits of 41 LK $31 / 32$ shall be stipulated by the proposer and an analysis of the impact of the proposed strategy on the resource base provided.

c. Analysis of collected data:

A11 data collected under items $b(1)$ and (2) above shall be analyzed in a manner consistent with the site-specific investigative design (item a. above). 
d. Reports:

The detailed results of the analysis (item c. above) shall be furnished to the Government in report form as follows:

\section{(1) Investigative report}

The investigative report shall contain details of all field work (item b. above) and analysis of data (item c. above). Two copies shall be initially submitted in draft status. Fifty copies of the final report shall be required.

The format of the investigative report shall be in accordance with "Guidelines to Formal Standards for Scientific and Technical Reports Prepared by or for the Federal Government," as issued December 1968 by the Committee on Scientific and Technical Information, Federal Council for Science and Technology, Washington, D.C. 20509.

The investigative report shall contain a list of keywords (descriptors) and a short informative abstract (about 200 words).

The "Scope of Work" of this contract shall be appended to and made a part of the required investigative report.

The Principal Investigator's signature shall appear on the lower right hand corner of the title page of all copies of the investigative report.

Prior to Bureau approval of the final investigative report, no portion of the study, its conclusions, or recommendations shall be released to any outside party, or otherwise publicized without prior consent of the Contracting Officer. See Clause No. 21 of this "General Provisions" concerning publication and copyright.

bimonthly.

(2) Two copies of a letter-type progress report shall be submitted 


\section{APPENDIX II}

RATES OF RECOVERY FOR SELECTED CLASSES OF DEBRIS BY UNIT AND LEVEL

The following printouts provide laboratory counts and/or weights for selected classes of debris recovered in excavations at 41 LK 31/32. Columns on each page are headed by the following entries:

SITE - The site number. Only 41 LK 31 is given, but listings also include units excavated at 41 LK 32.

NORTH/EAST - Grid coordinates at the southwest corner of the excavation unit.

LEV - Vertical level in the excavation unit starting with the surface level(1) and proceeding downward.

A Tuff rock weight, in grams*

B Sandstone weight, in grams*

C Fire-fractured rock weight, in grams*

D Mussel shel1 umbo count

E Mussel shel1 weight (umbos and fragments combined), in grams*

F Rabdotus shell count (whole shells only)

$G$ Bone weight, in grams*

H Primary flakes, total count

I Primary flakes, modified, total count

$\mathrm{J}$ Secondary flakes, total count

K Secondary flakes, modified, total count

L Tertiary flakes, total count

M Tertiary flakes, modified, total count

N Chips, total count

*Last digit in each weight figure represents tenths of a gram. 


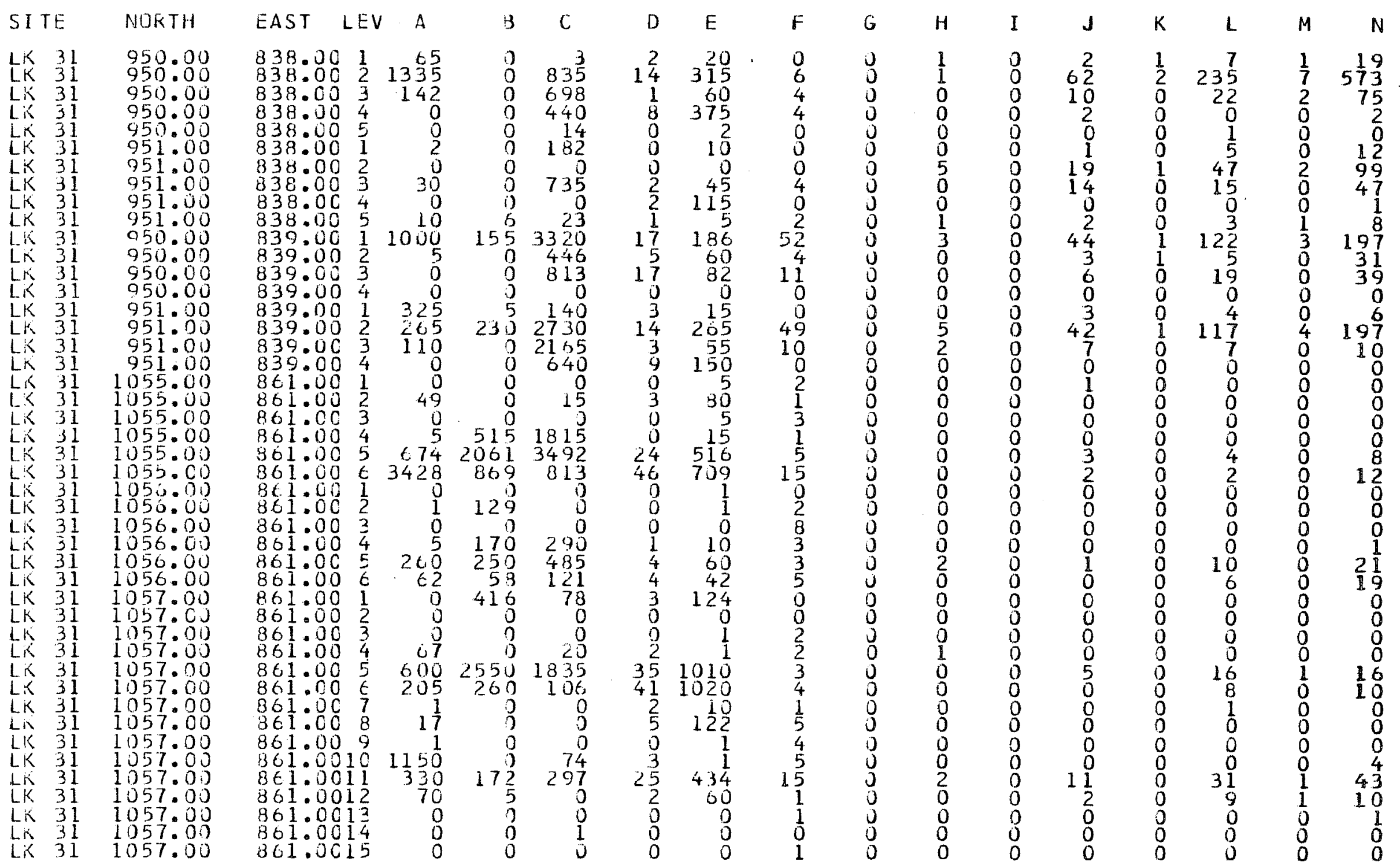




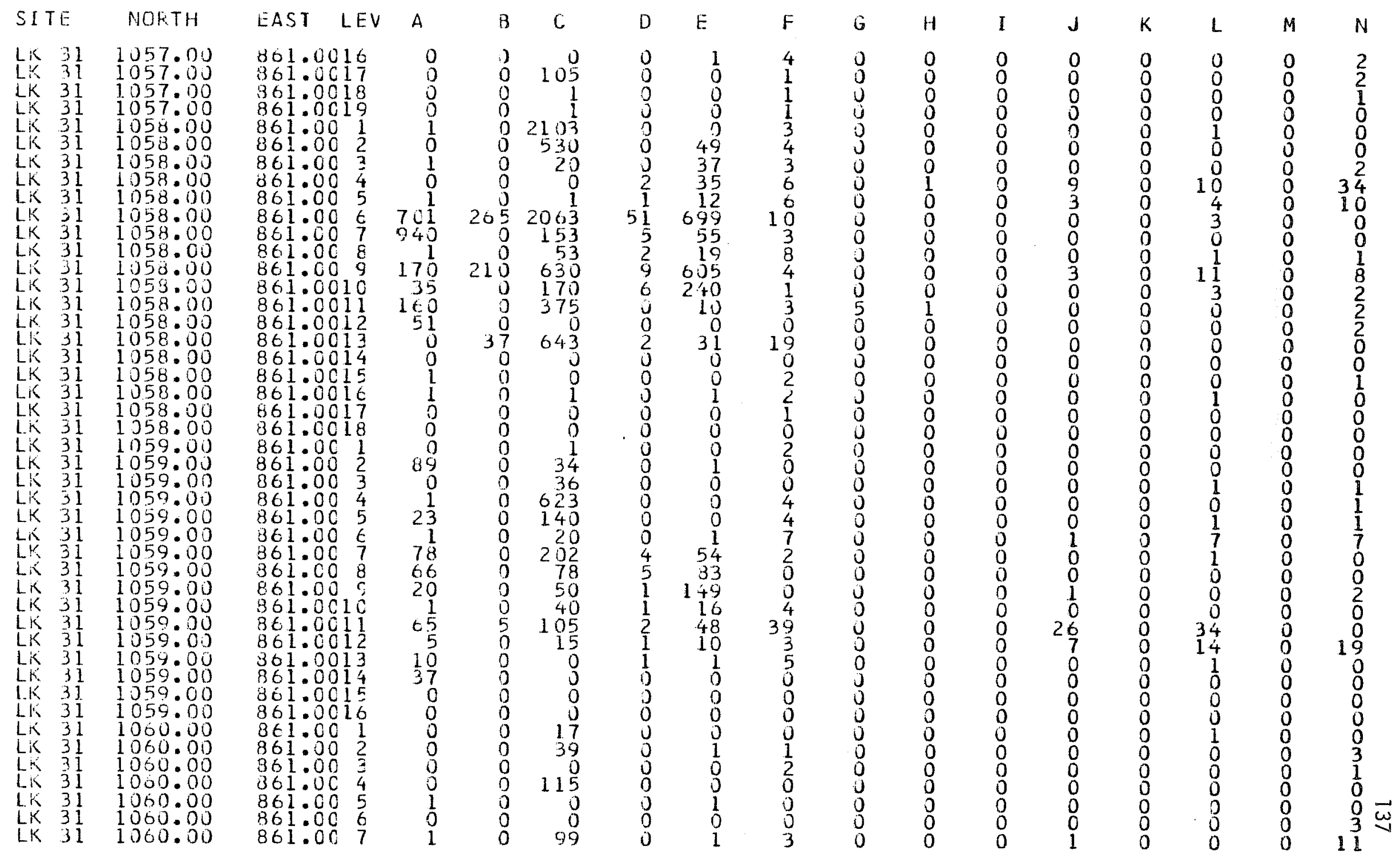




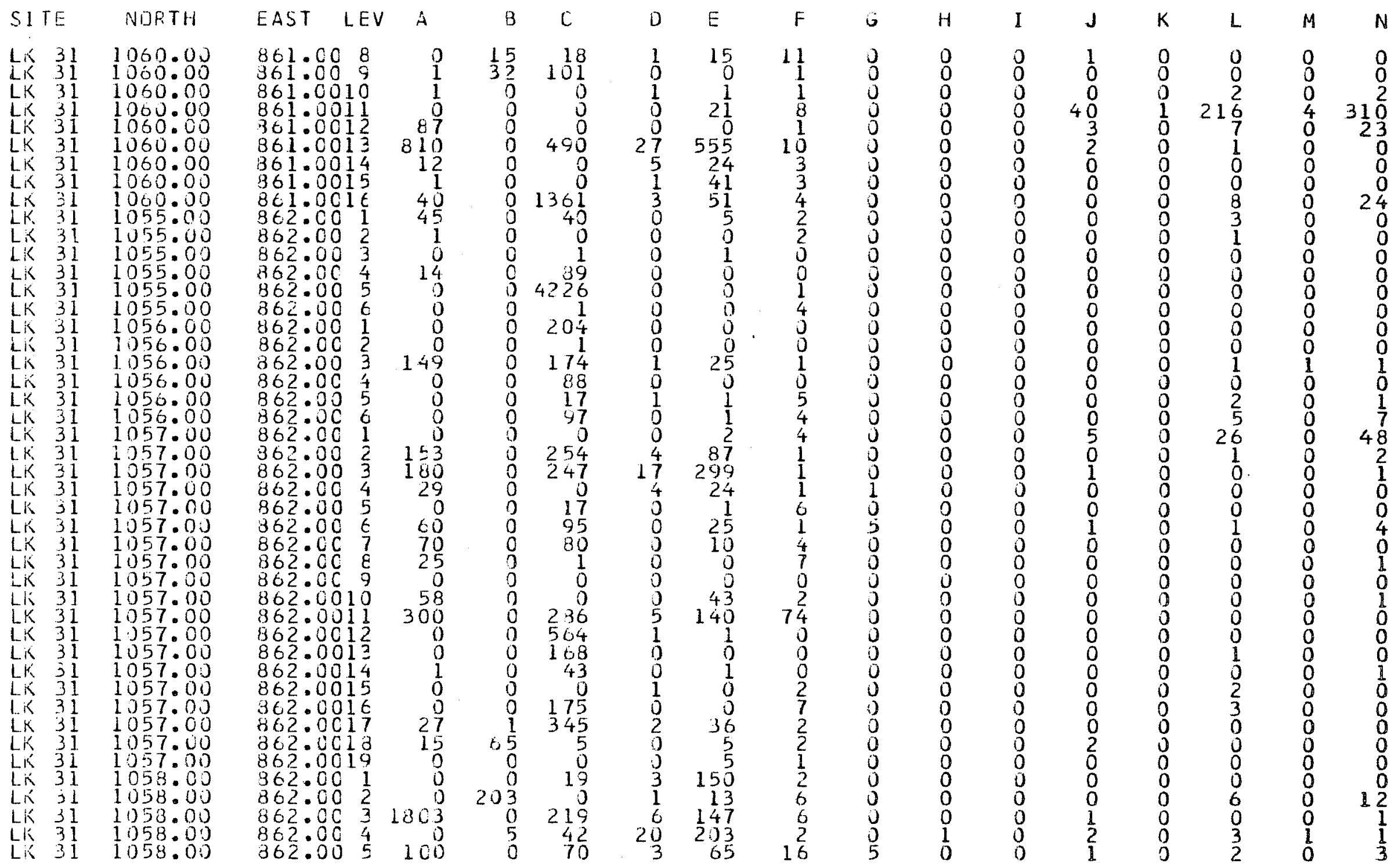




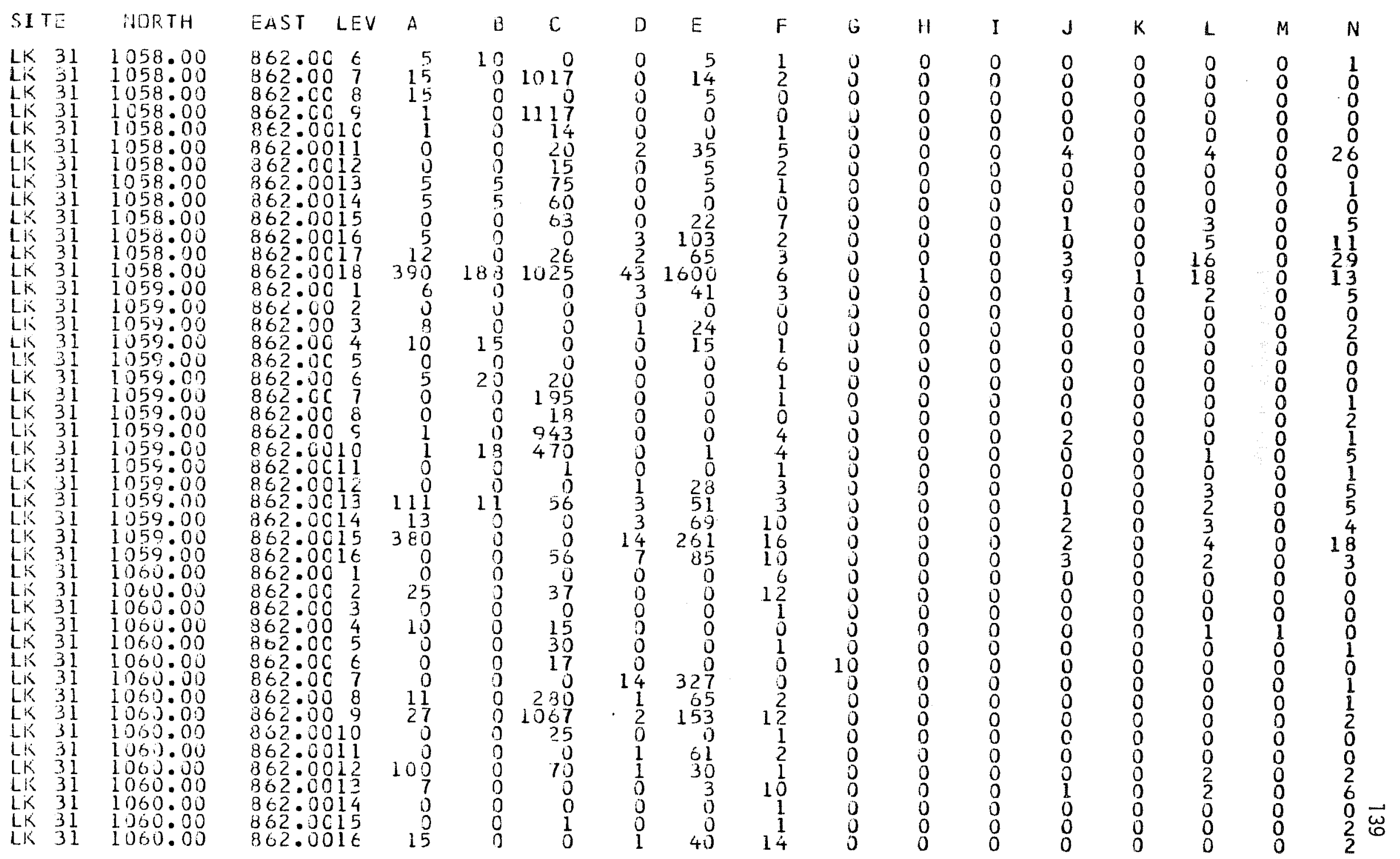




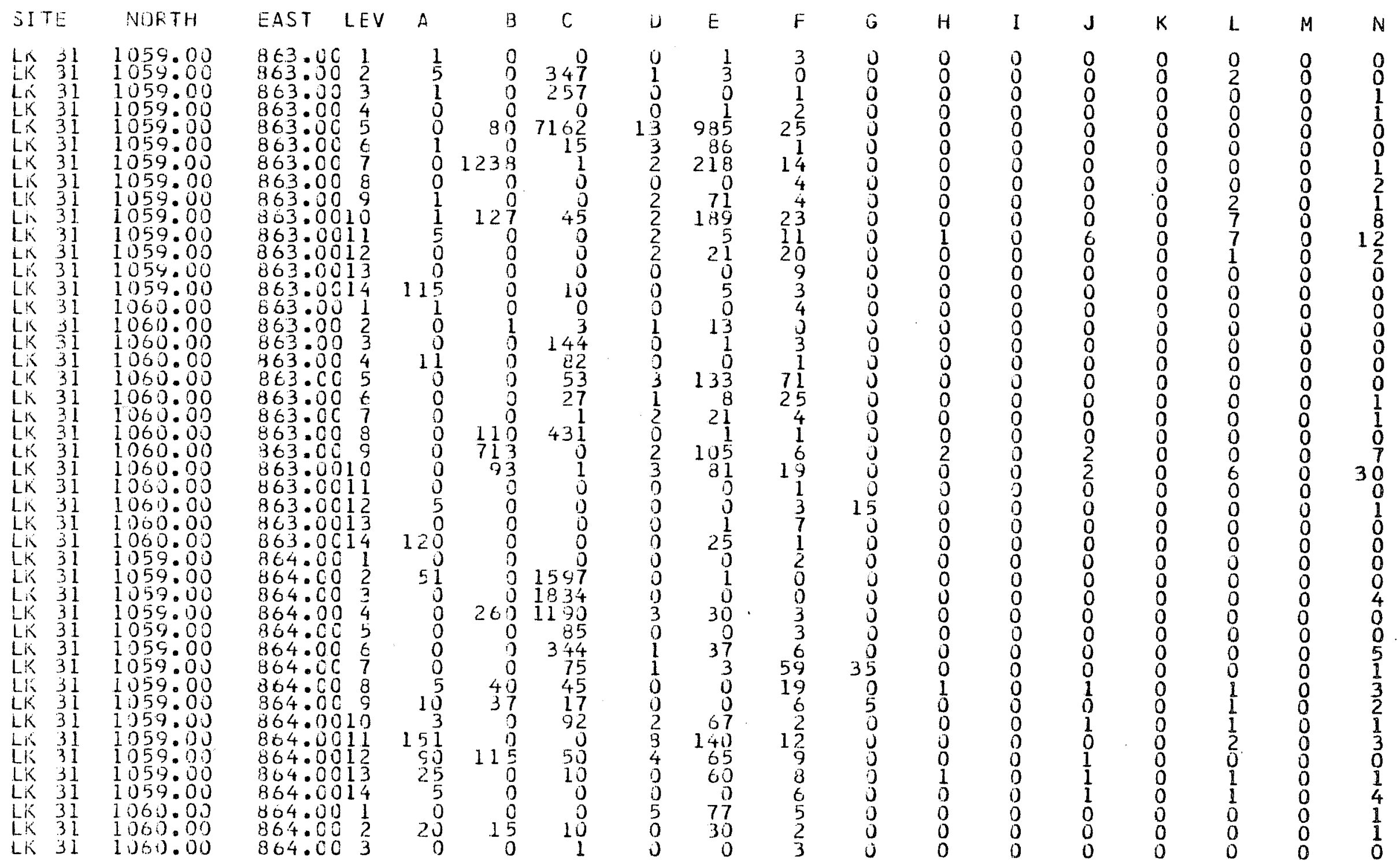




\begin{tabular}{|c|c|c|c|c|c|c|c|c|c|c|c|c|c|c|c|c|}
\hline IITE & NOF.TH & EAST LEV & A & $B$ & C & 0 & $E$ & $F$ & G & $\mathrm{H}$ & I & $J$ & $k$ & $L$ & $M$ & $N$ \\
\hline 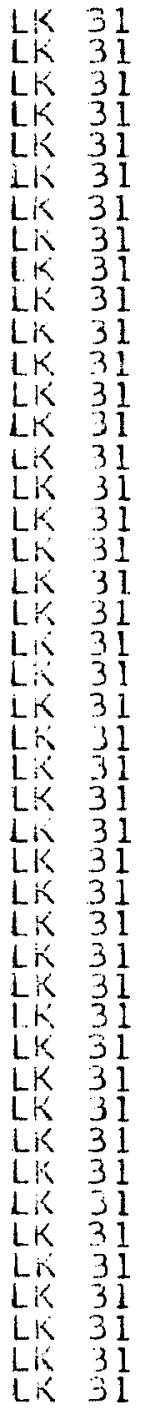 & $\begin{array}{l}1060: 00 \\
1060: 00 \\
1060: 00 \\
1060: 00 \\
1060: 000 \\
1060: 00 \\
1060: 00 \\
1060: 00 \\
1060: 00 \\
1060: 00 \\
1060: 00 \\
1059: 00 \\
1059: 00 \\
1059: 00 \\
1059: 00 \\
1059: 00 \\
1059: 00 \\
1059: 00 \\
1059: 00 \\
1059: 00 \\
1059: 00 \\
1059: 00 \\
1059: 00 \\
1059: 00 \\
1059: 00 \\
1060: 00 \\
1060: 00 \\
1060: 00 \\
1060: 00 \\
1060: 00 \\
1060: 00 \\
1060: 00 \\
1060: 00 \\
1060: 00 \\
1060000 \\
1060: 00 \\
1060.00 \\
1060: 00 \\
1060: 00 \\
1057: 00 \\
1057: 00 \\
1058: 00 \\
1058.00 \\
1058: 000 \\
1059.00\end{array}$ & 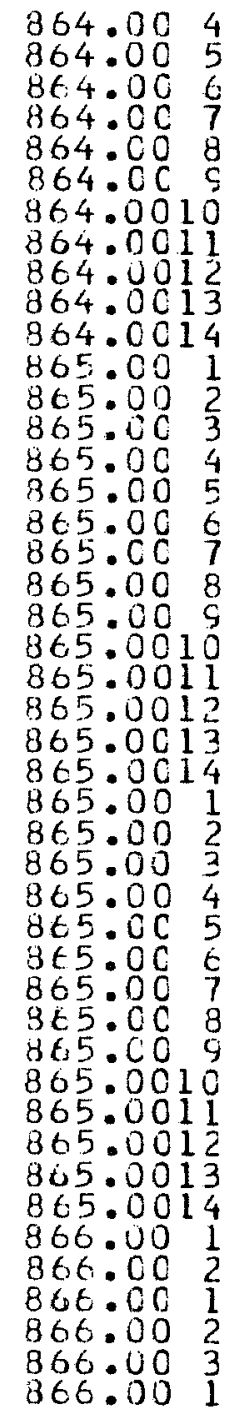 & $\begin{array}{r}0 \\
0 \\
25 \\
0 \\
0 \\
23 \\
10 \\
0 \\
0 \\
66 \\
9999 \\
10 \\
0 \\
0 \\
50 \\
22 \\
10 \\
18 \\
1 \\
1 \\
0 \\
0 \\
0 \\
15 \\
999 \\
296 \\
11 \\
1 \\
0 \\
0 \\
0 \\
0 \\
1 \\
59 \\
26 \\
5 \\
0 \\
324 \\
996 \\
38 \\
19 \\
417 \\
18 \\
1 \\
0\end{array}$ & $\begin{array}{r}0 \\
0 \\
0 \\
0 \\
5 \\
70 \\
20 \\
0 \\
0 \\
0 \\
230 \\
0 \\
0 \\
0 \\
0 \\
708 \\
0 \\
0 \\
0 \\
0 \\
0 \\
0 \\
0 \\
180 \\
00 \\
150 \\
153 \\
0 \\
0 \\
0 \\
0 \\
0 \\
0 \\
0 \\
30 \\
0 \\
10 \\
100 \\
0 \\
3132 \\
32 \\
0 \\
0 \\
0\end{array}$ & $\begin{array}{r}30 \\
363 \\
465 \\
20 \\
5 \\
82 \\
105 \\
35 \\
50 \\
0 \\
217 \\
285 \\
25 \\
54 \\
5 \\
00 \\
130 \\
997 \\
378 \\
323 \\
100 \\
46 \\
35 \\
110 \\
953 \\
300 \\
0 \\
00 \\
150 \\
6 \\
0 \\
198 \\
986 \\
1864 \\
3604 \\
230 \\
15 \\
700 \\
0 \\
1 \\
0 \\
306 \\
0 \\
0\end{array}$ & $\begin{array}{r}0 \\
0 \\
1 \\
0 \\
0 \\
0 \\
0 \\
15 \\
1 \\
6 \\
22 \\
0 \\
0 \\
0 \\
0 \\
0 \\
0 \\
0 \\
1 \\
0 \\
0 \\
2 \\
4 \\
5 \\
6 \\
1 \\
0 \\
0 \\
0 \\
0 \\
0 \\
4 \\
4 \\
0 \\
7 \\
9 \\
14 \\
4 \\
1 \\
0 \\
0 \\
1\end{array}$ & $\begin{array}{r}0 \\
1 \\
45 \\
0 \\
0 \\
0 \\
5 \\
472 \\
50 \\
130 \\
771 \\
20 \\
5 \\
5 \\
5 \\
0 \\
0 \\
0 \\
0 \\
92 \\
0 \\
0 \\
25 \\
46 \\
61 \\
75 \\
1 \\
1 \\
0 \\
0 \\
0 \\
0 \\
0 \\
69 \\
63 \\
70 \\
70 \\
90 \\
458 \\
29 \\
21 \\
21 \\
1\end{array}$ & $\begin{array}{r}0 \\
3 \\
6 \\
1 \\
3 \\
7 \\
2 \\
6 \\
6 \\
8 \\
7 \\
10 \\
8 \\
4 \\
6 \\
7 \\
0 \\
1 \\
3 \\
8 \\
1 \\
2 \\
6 \\
9 \\
9 \\
11 \\
6 \\
4 \\
7 \\
3 \\
0 \\
1 \\
1 \\
6 \\
4 \\
6 \\
0 \\
11 \\
22 \\
4 \\
2 \\
3 \\
10 \\
6 \\
0\end{array}$ & $\begin{array}{l}0 \\
0 \\
0 \\
0 \\
0 \\
0 \\
0 \\
0 \\
0 \\
0 \\
0 \\
0 \\
0 \\
0 \\
0 \\
0 \\
0 \\
0 \\
0 \\
0 \\
0 \\
0 \\
0 \\
0 \\
0 \\
0 \\
0 \\
0 \\
0 \\
0 \\
0 \\
0 \\
0 \\
0 \\
0 \\
0 \\
0 \\
0 \\
0 \\
0 \\
0 \\
0 \\
0 \\
0 \\
0\end{array}$ & $\begin{array}{l}0 \\
0 \\
0 \\
0 \\
0 \\
0 \\
0 \\
0 \\
1 \\
0 \\
1 \\
0 \\
0 \\
0 \\
0 \\
0 \\
0 \\
0 \\
0 \\
0 \\
0 \\
0 \\
0 \\
0 \\
0 \\
0 \\
0 \\
0 \\
0 \\
0 \\
1 \\
0 \\
0 \\
0 \\
0 \\
0 \\
0 \\
0 \\
0 \\
0 \\
0 \\
0 \\
0\end{array}$ & $\begin{array}{l}0 \\
0 \\
0 \\
0 \\
0 \\
0 \\
0 \\
0 \\
0 \\
0 \\
0 \\
0 \\
0 \\
0 \\
0 \\
0 \\
0 \\
0 \\
0 \\
0 \\
0 \\
0 \\
0 \\
0 \\
0 \\
0 \\
0 \\
0 \\
0 \\
0 \\
0 \\
0 \\
0 \\
0 \\
0 \\
0 \\
0 \\
0 \\
0 \\
0 \\
0\end{array}$ & $\begin{array}{l}1 \\
0 \\
0 \\
0 \\
0 \\
0 \\
2 \\
1 \\
1 \\
0 \\
6 \\
1 \\
0 \\
0 \\
0 \\
0 \\
0 \\
0 \\
0 \\
0 \\
0 \\
0 \\
0 \\
3 \\
3 \\
2 \\
0 \\
0 \\
0 \\
1 \\
0 \\
0 \\
0 \\
0 \\
0 \\
1 \\
0 \\
0 \\
3 \\
2 \\
1 \\
1 \\
0 \\
0 \\
0\end{array}$ & $\begin{array}{l}0 \\
0 \\
0 \\
0 \\
0 \\
0 \\
0 \\
0 \\
1 \\
0 \\
1 \\
0 \\
0 \\
0 \\
0 \\
0 \\
0 \\
0 \\
0 \\
0 \\
0 \\
0 \\
0 \\
0 \\
0 \\
0 \\
0 \\
0 \\
0 \\
0 \\
0 \\
0 \\
0 \\
0 \\
0 \\
0 \\
0 \\
0 \\
0 \\
0 \\
0 \\
0 \\
0 \\
0 \\
0\end{array}$ & $\begin{array}{r}0 \\
0 \\
0 \\
0 \\
0 \\
0 \\
2 \\
2 \\
4 \\
3 \\
11 \\
0 \\
0 \\
0 \\
0 \\
0 \\
0 \\
0 \\
0 \\
0 \\
0 \\
2 \\
2 \\
2 \\
7 \\
4 \\
2 \\
1 \\
0 \\
0 \\
0 \\
1 \\
0 \\
2 \\
0 \\
1 \\
0 \\
0 \\
1 \\
3 \\
1 \\
0 \\
1 \\
0 \\
0\end{array}$ & $\begin{array}{l}0 \\
0 \\
0 \\
0 \\
0 \\
0 \\
0 \\
0 \\
0 \\
0 \\
1 \\
0 \\
0 \\
0 \\
0 \\
0 \\
0 \\
0 \\
0 \\
0 \\
0 \\
0 \\
0 \\
0 \\
0 \\
0 \\
1 \\
0 \\
0 \\
0 \\
0 \\
0 \\
0 \\
0 \\
0 \\
0 \\
0 \\
0 \\
0 \\
0 \\
0 \\
0 \\
0 \\
0 \\
0\end{array}$ & $\begin{array}{r}3 \\
0 \\
2 \\
0 \\
0 \\
0 \\
1 \\
1 \\
0 \\
8 \\
10 \\
18 \\
14 \\
4 \\
1 \\
0 \\
0 \\
0 \\
0 \\
1 \\
1 \\
3 \\
1 \\
1 \\
06 \\
0 \\
12 \\
12 \\
4 \\
4 \\
4 \\
0 \\
0 \\
0 \\
0 \\
0 \\
2 \\
0 \\
1 \\
\frac{1}{3} \\
0 \\
0 \\
1 \\
8 \\
8 \\
2 \\
11 \\
0 \\
0 \\
5 \\
1 \\
0\end{array}$ \\
\hline
\end{tabular}




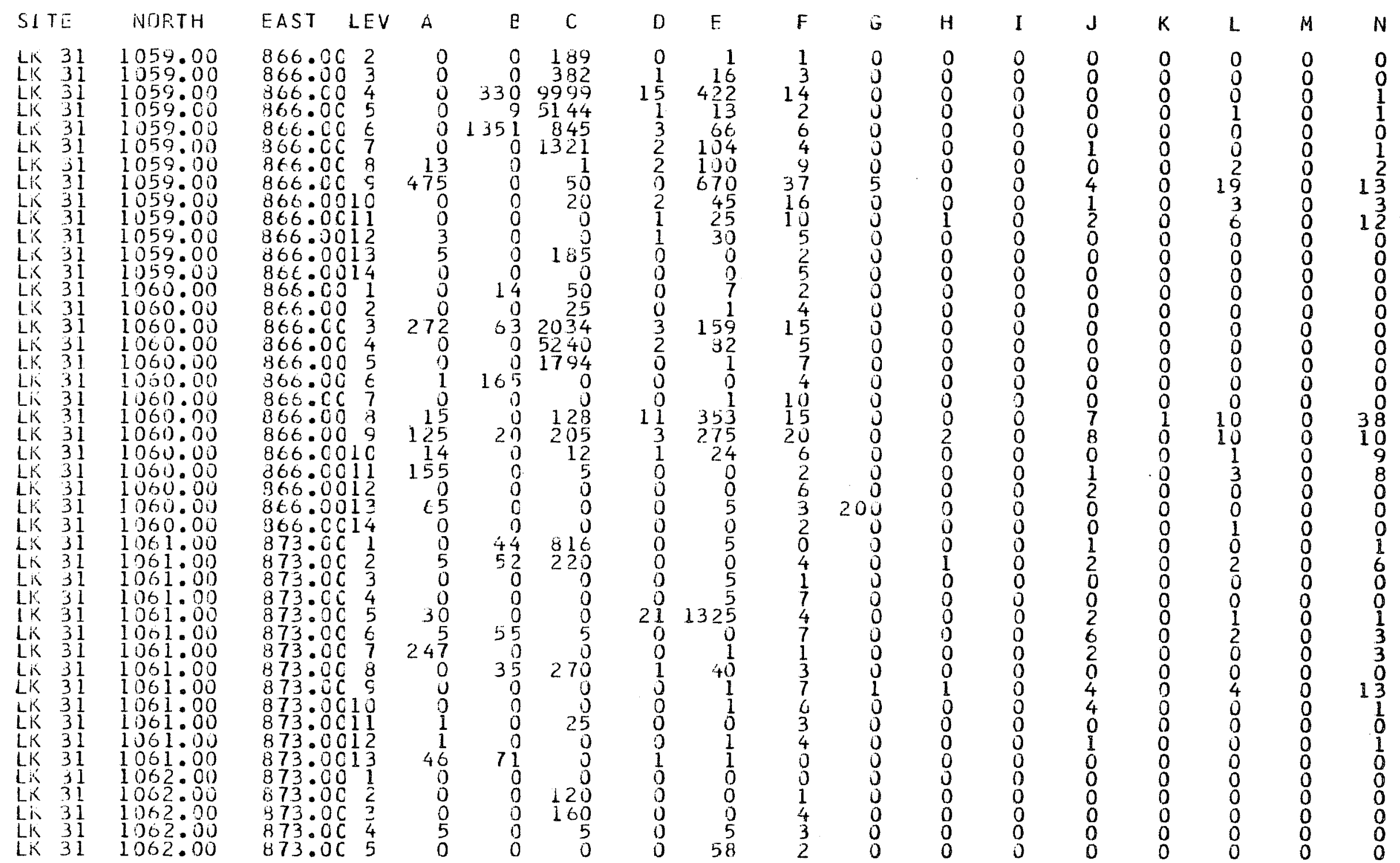




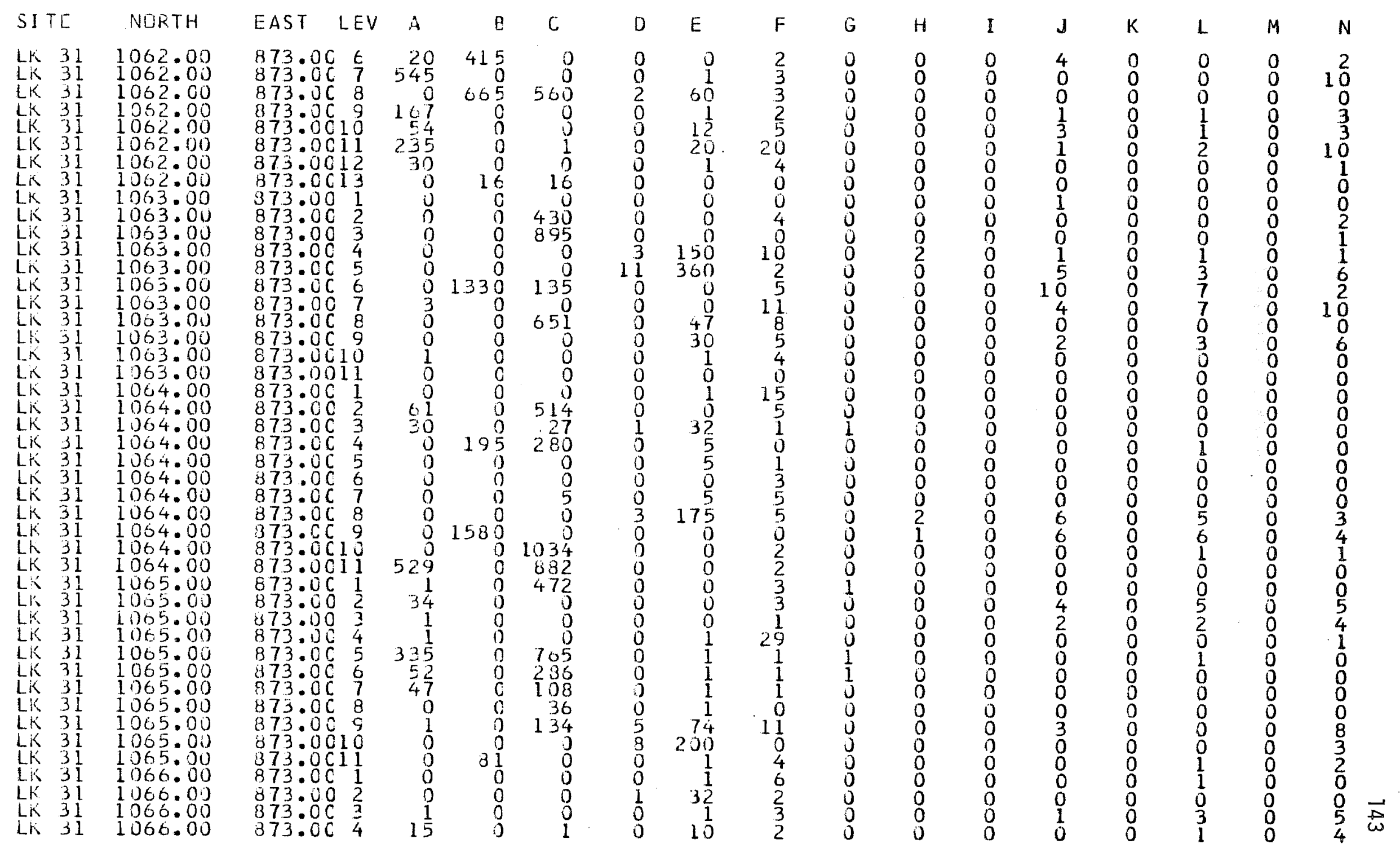




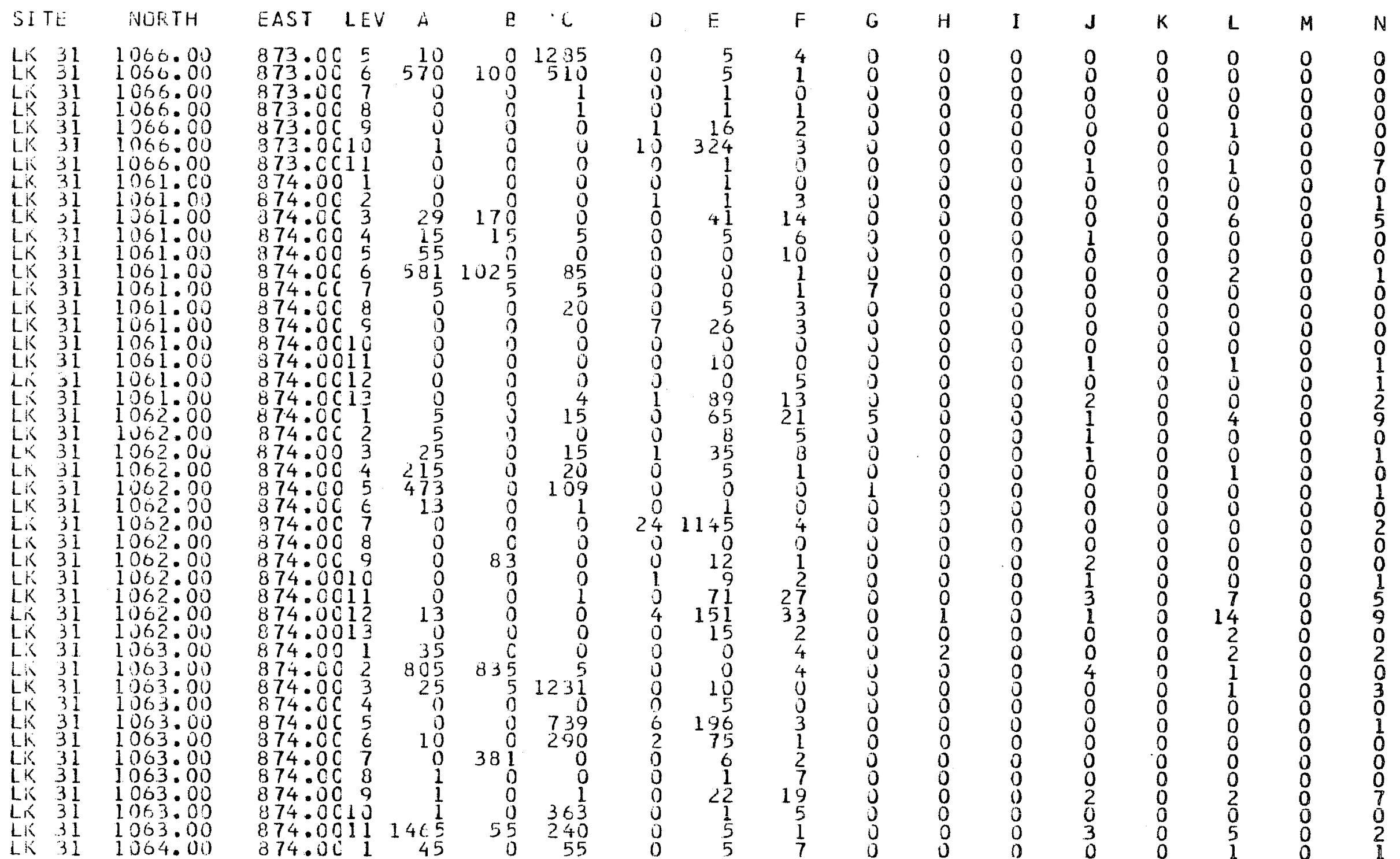




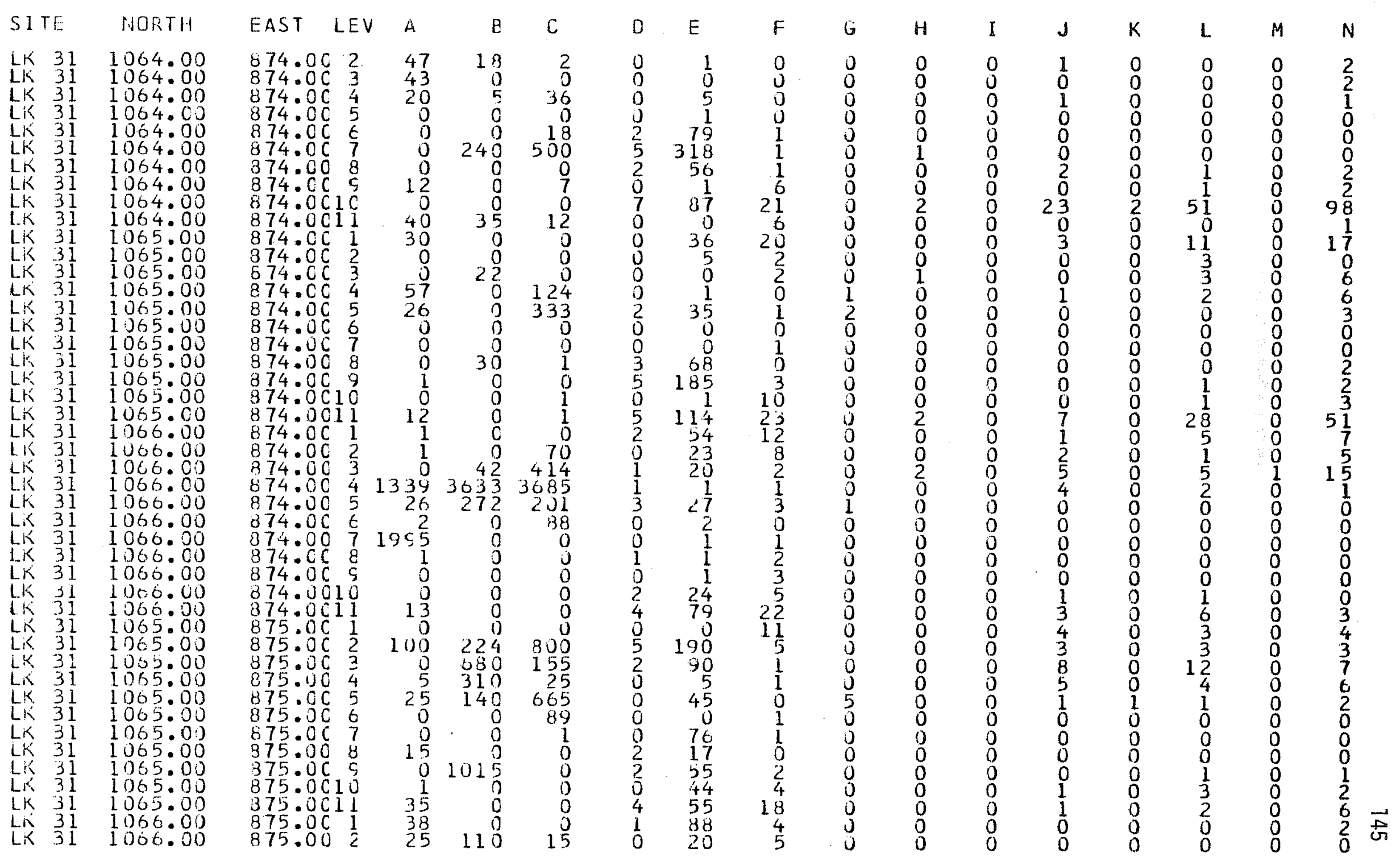




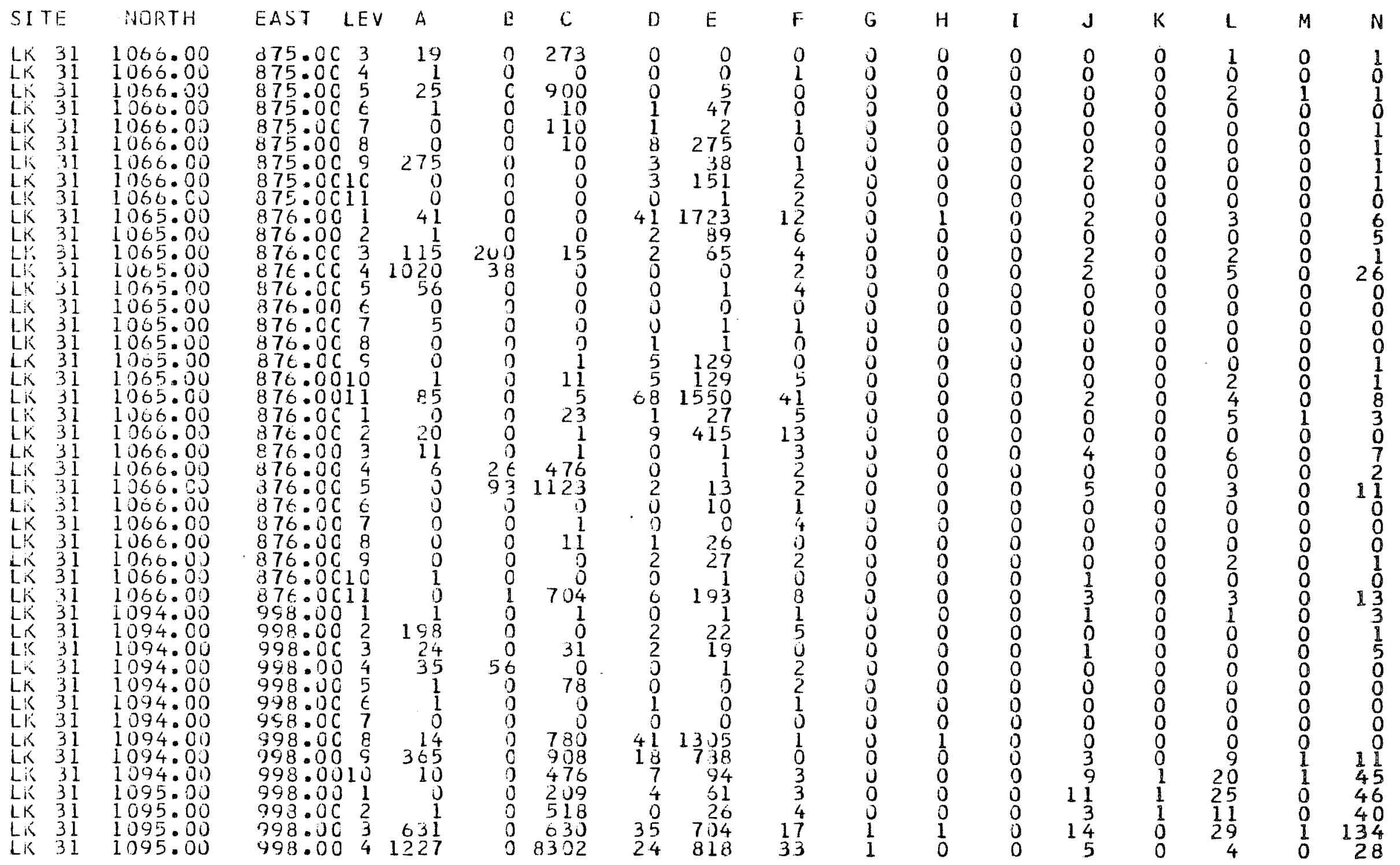




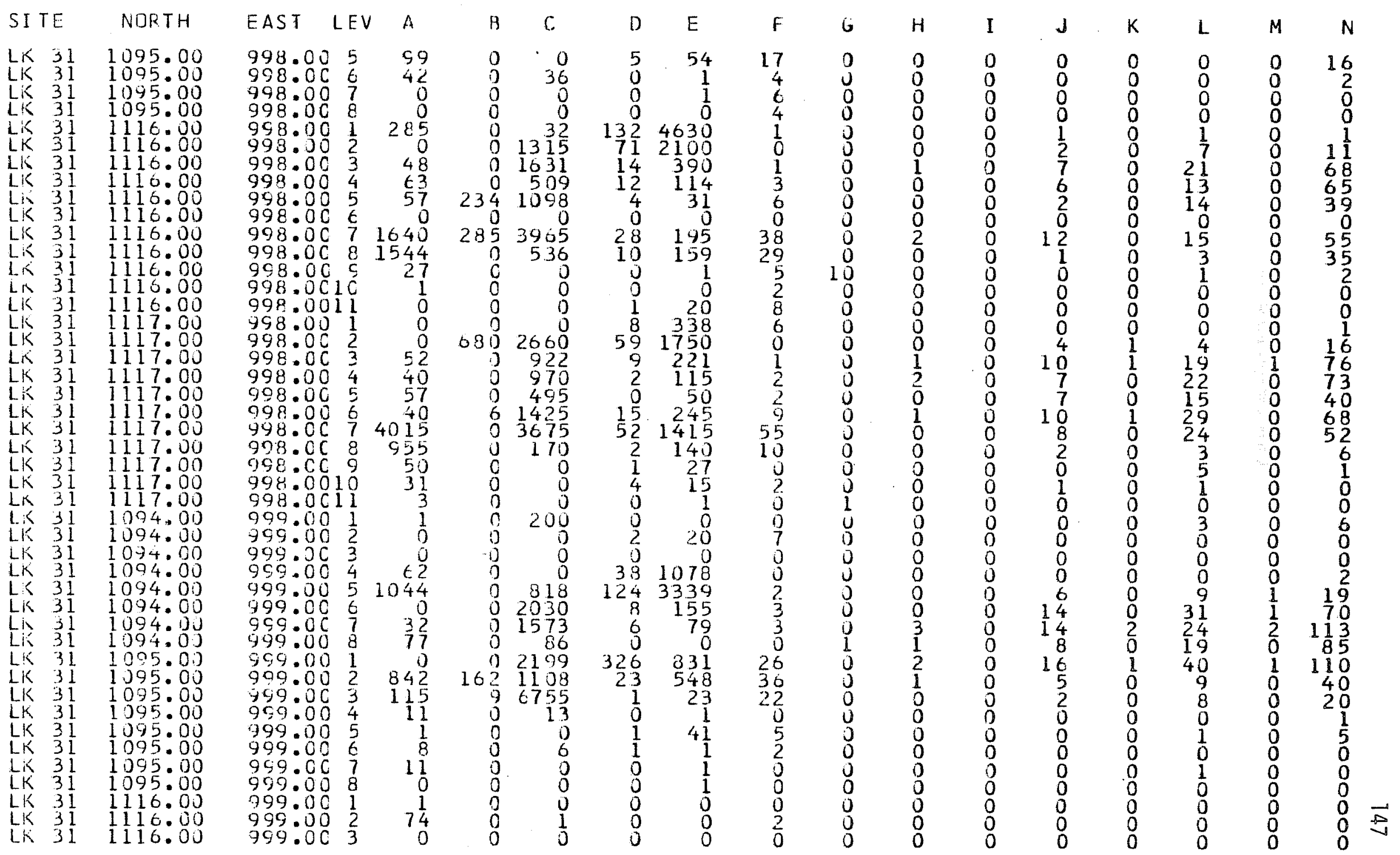




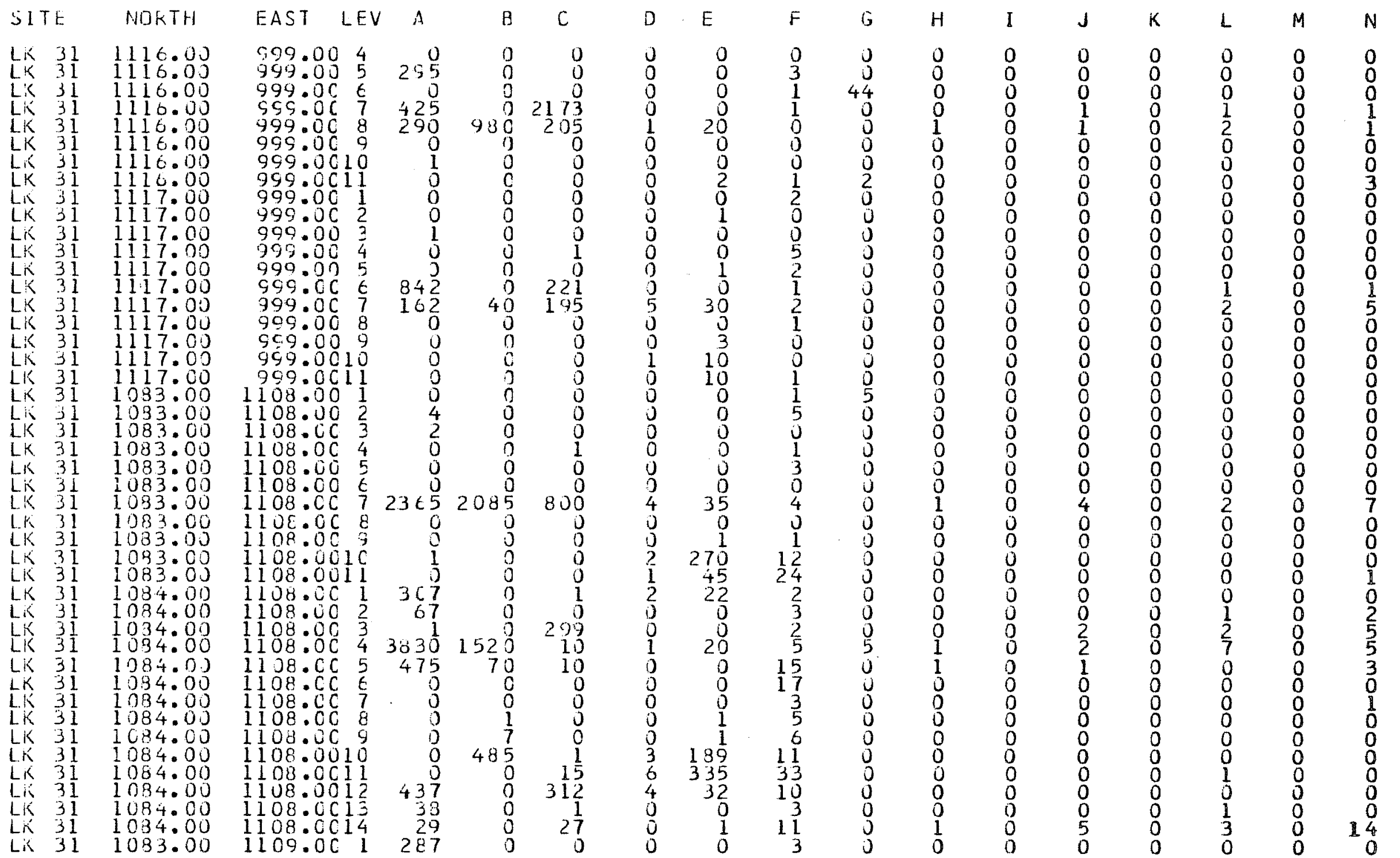




\begin{tabular}{|c|c|c|c|c|c|c|c|c|c|c|c|c|c|c|c|c|}
\hline SITE & NURTH & EAST & $A$ & $B$ & $\mathrm{C}$ & i) & $E$ & $F$ & $\dot{j}$ & $H$ & I & $J$ & $k$ & L & $M$ & $N$ \\
\hline $\begin{array}{ll}L K & 31 \\
L K & 31 \\
L K & 31 \\
L K & 31 \\
L K & 31 \\
L K & 31 \\
L K & 31 \\
L K & 31 \\
L K & 31 \\
L K & 31 \\
L K & 31 \\
L K & 31 \\
L K & 31 \\
L K & 31 \\
L K & 31 \\
L K & 31 \\
L K & 31 \\
L K & 31 \\
L K & 31 \\
L K & 31 \\
L K & 31 \\
L K & 31 \\
L K & 31 \\
L K & 31 \\
L K & 31 \\
L K & 31\end{array}$ & $\begin{array}{l}1083.00 \\
1033.00 \\
1083.00 \\
1033.00 \\
1033.00 \\
1093.00 \\
1083.00 \\
1083.00 \\
1083.00 \\
1083.00 \\
1084.00 \\
1034.00 \\
1084.00 \\
1094.00 \\
1034.00 \\
1084.00 \\
1084.00 \\
1084.00 \\
1084.00 \\
1084.00 \\
1084.00 \\
1084.00 \\
1084.00 \\
1084.00 \\
1084.00 \\
1084.00\end{array}$ & 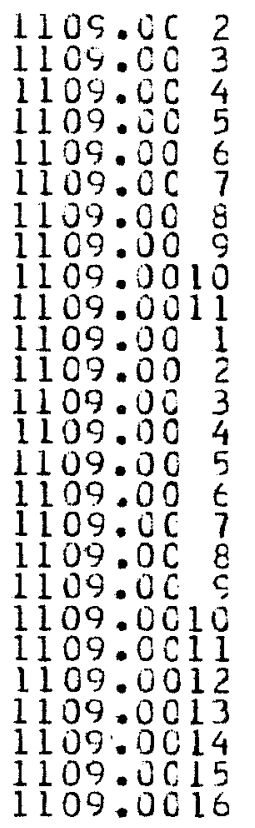 & $\begin{array}{r}0 \\
0 \\
0 \\
0 \\
0 \\
0 \\
0 \\
718 \\
2473 \\
480 \\
288 \\
0 \\
0 \\
2160 \\
0 \\
35 \\
1331 \\
1193 \\
847 \\
4020 \\
1310 \\
306 \\
35 \\
1 \\
0\end{array}$ & 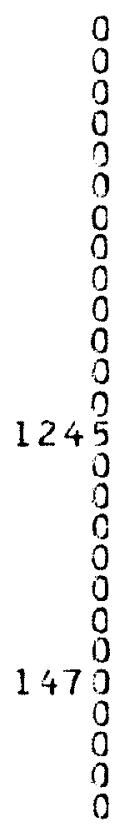 & $\begin{array}{r}0 \\
0 \\
0 \\
0 \\
0 \\
15 \\
45 \\
0 \\
1 \\
19 \\
2230 \\
0 \\
0 \\
0 \\
405 \\
0 \\
0 \\
0 \\
0 \\
0 \\
37 \\
1 \\
30 \\
9 \\
0 \\
0 \\
0\end{array}$ & $\begin{array}{l}0 \\
0 \\
0 \\
0 \\
3 \\
1 \\
0 \\
0 \\
0 \\
0 \\
0 \\
0 \\
0 \\
1 \\
0 \\
0 \\
1 \\
7 \\
0 \\
1 \\
1 \\
0 \\
0\end{array}$ & $\begin{array}{r}0 \\
0 \\
1 \\
1 \\
124 \\
35 \\
1 \\
55 \\
0 \\
0 \\
0 \\
0 \\
0 \\
25 \\
1 \\
1 \\
121 \\
800 \\
1 \\
45 \\
1 \\
0 \\
1 \\
1 \\
0 \\
0\end{array}$ & $\begin{array}{r}7 \\
2 \\
12 \\
3 \\
11 \\
0 \\
5 \\
7 \\
4 \\
8 \\
6 \\
62 \\
17 \\
13 \\
6 \\
2 \\
35 \\
56 \\
8 \\
10 \\
19 \\
9 \\
1 \\
0 \\
6 \\
4\end{array}$ & $\begin{array}{l}0 \\
0 \\
0 \\
0 \\
0 \\
j \\
0 \\
0 \\
0 \\
0 \\
0 \\
0 \\
0 \\
j \\
0 \\
1 \\
0 \\
0 \\
j \\
0 \\
0 \\
1 \\
0 \\
0 \\
0 \\
0\end{array}$ & $\begin{array}{l}0 \\
0 \\
0 \\
0 \\
0 \\
0 \\
0 \\
0 \\
1 \\
0 \\
0 \\
2 \\
0 \\
0 \\
0 \\
0 \\
0 \\
0 \\
0 \\
0 \\
0 \\
1 \\
0 \\
0 \\
0 \\
0\end{array}$ & $\begin{array}{l}0 \\
0 \\
0 \\
0 \\
0 \\
0 \\
0 \\
0 \\
0 \\
0 \\
0 \\
0 \\
0 \\
0 \\
0 \\
0 \\
0 \\
0 \\
0 \\
0 \\
0 \\
0 \\
0 \\
0 \\
0 \\
0 \\
0\end{array}$ & $\begin{array}{r}0 \\
0 \\
0 \\
1 \\
0 \\
0 \\
0 \\
0 \\
2 \\
0 \\
0 \\
14 \\
0 \\
4 \\
0 \\
0 \\
0 \\
0 \\
0 \\
1 \\
2 \\
4 \\
0 \\
0 \\
0 \\
0\end{array}$ & $\begin{array}{l}0 \\
0 \\
0 \\
1 \\
0 \\
0 \\
0 \\
0 \\
1 \\
0 \\
0 \\
0 \\
0 \\
0 \\
0 \\
0 \\
0 \\
0 \\
0 \\
0 \\
0 \\
0 \\
0 \\
0 \\
0 \\
0\end{array}$ & $\begin{array}{l}0 \\
0 \\
0 \\
0 \\
0 \\
0 \\
0 \\
1 \\
4 \\
2 \\
0 \\
1 \\
0 \\
18 \\
0 \\
0 \\
0 \\
0 \\
0 \\
1 \\
3 \\
3 \\
1 \\
0 \\
0 \\
0\end{array}$ & $\begin{array}{l}0 \\
0 \\
0 \\
0 \\
0 \\
0 \\
0 \\
0 \\
0 \\
0 \\
0 \\
0 \\
0 \\
0 \\
0 \\
1 \\
0 \\
0 \\
0 \\
0 \\
0 \\
0 \\
0 \\
0 \\
0 \\
0 \\
0 \\
0 \\
0 \\
0\end{array}$ & $\begin{array}{r}0 \\
0 \\
0 \\
1 \\
0 \\
0 \\
0 \\
4 \\
6 \\
14 \\
0 \\
23 \\
23 \\
23 \\
0 \\
0 \\
0 \\
0 \\
0 \\
0 \\
8 \\
6 \\
2 \\
1 \\
0 \\
0\end{array}$ \\
\hline
\end{tabular}


APPENDIX III

\section{GLOSSARY}

biface

chip

chipped stone

cortex

cultural debris

cultural horizon

cultural zone

dart point

debitage

feature (cultural feature) a chipped stone tool or tool fragment shaped by knapping flakes from two opposite sides as a means of gradual7y thinning the piece to the desired form.

a portion of a flake which, due to breakage, crushing, or shattering, has no striking platform. Chips are an incidental product of chipped stone tool manufacture.

any piece of stone which has been intentionally altered by the aborigine through removal of flakes for the purpose of stone tool production.

on a cobble, the exterior weathered surface or rind which usually conceals the interior color and material quality of the rock.

material remains produced or altered, either directly or indirectly, as a result of human activity. At Choke Canyon, this term specifically applies to surviving materials evidencing the sites of prehistoric and/or early historic human activities in the area.

within a given layer of earth in the subsurface of a site, a cultural horizon is an aggregate of cultural debris representing a given period of time in prehistory.

a vertically restricted stratum of earth in the subsurface of a site containing cultural debris deposited during a period of time more limited in time than a horizon (see above)。

a bifacial chipped stone projectile designed to be attached to a short wooden shaft in the manner of a javelin. In size, the dart point and its shaft are midway between a spear and an arrow. The dart could be hurled by itself or thrown with an atlate (spearthrower), a device affording added power to the thrust of the weapon. The bow and arrow did not come into use in the Choke Canyon region until approximately A.D. 1300. The dart was the principal projectile-type weapon prior to this time.

all residues (flakes, chips, chunks) resulting from the manufacture of chipped stone tools.

the surviving evidence of a specific human activity (or set of activities) which occurred in the past over a spatially restricted area within a site. A feature might be a hearth 
feature fill

flake

ground stone

hammerstone

hand screening

hearth

hunter/gatherers

Tithic debitage

lithic scatter (see below); a concentration of mussel and snail shell; an accumulation of cores, debitage, and stone tools and tool fragments; or a stain in the earth marking a shallow pit dug as an oven, trash pit, or cache.

the earth matrix surrounding or contained within the objects or other manifestations constituting a cultural feature. The feature fil1 sometimes contains minute remains, such as bone and carbon, which provide clues to feature function.

one type of debitage produced as a rock is being chipped into a stone tool. A flake always retains a striking platform marking the point at which the parent rock was struck to knock the flake off. The flake is usually thickest at the striking platform and thins out towards the other end. A flake may itself serve as a tool (see utilized flake definition below).

a rock which has been smoothed and/or shaped by man either

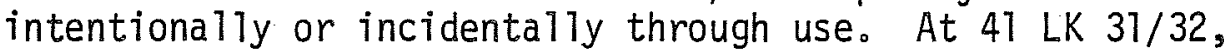
the term applies to fragments of sands tone which retain evidence of use as grinding slabs (metates) which were smoothed and faceted by abrasion as plant products (seeds and beans?) were prepared for human consumption.

a rock, usially quartzite or durable igneous material, used as a hammer to shape chipped stone tools.

the manual process of working excavated matrix through hardware cloth for the purpose of recovering cultural debris contained therein (contrast to water screening below).

a place in a site where prehistoric people built a fire. Most often the hearth is recognized as a tight cluster of rock. A hearth might also be evidenced simply as an area of fired earth. Hearths often contain carbon and are surrounded by debris (mussel she11, snail she11, debitage) evidencing food items prepared over the fire and activities carried out beside it.

a term applied to people who survived by hunting available species of wildlife and gathering all manner of plant and animal products fit for human consumption. The term usually implies a nomadic, impermanently-settled way of $7 i \mathrm{fe}$ requiring close harmony with nature.

same as debitage (see above).

an accumulation of cores, debitage, chipped stone tools, and/or fire-altered rocks visible on the ground surface of an area. 
living floor

or surface

otolith

paleoclimate

patrilinea 1

phytolith

pit oven

profile

radiocarbon date

subsistence cycle a now-buried, vertically restricted plane or level within a site which was once the exposed ground surface upon which past human activity occurred. Cultural debris deposited during the activity, if not later disturbed, marks the surface and may yield to the archaeologist information concerning the character and topography of the buried surface.

a thick, subcircular bone element found in the skull area of some fish. Relatively durable, otoliths are often the only bones found in prehistoric sites at Choke Canyon.

the climate as it was in prehistory. At Choke Canyon, as in many other places, present climatic conditions are remarkably different from those experienced by people during certain periods in the area's prehistory.

a system of tracing ancestry through the male line in human society.

microscopic cellular structures of silica found in many types of plants. Being of silica, phytoliths may be preserved in the soil for thousands of years. As each plant produces phytoliths in different forms, the phytoliths may be analyzed to determine types of plants present at any given time in the prehistory. Still in its infancy, phytolith research has not yet been perfected to the extent that reliable reconstructions of prehistoric plant communities can be made.

a type of prehistoric hearth made by digging a shallow hole in the ground. The food item to be cooked, usually some kind of plant product, was placed in the hole and covered with a layer of soil over which coals or heated rocks were placed.

the vertical wall of an excavation unit, backhoe trench, or geologic test pit in which the natural layering of the soil (stratification) may be seen. Layers or strata within the soil may also be the result of human activities on earlier, now-buried surfaces with the site (stratigraphy).

an absolute age calculated through a complex analytical procedure in which samples of organic residues (usually carbon, but also shell, bone, and organic-rich earth) are assayed to determine the time when the organism yielding the organic material actually lived.

for hunter/gatherers, the annual pattern of movement over a territory designed to take best advantage of food resources available at given places at given times of the year. 
thermal spal1

(fracture)

umbo

uniface

utilized flake

water screening fragmentation of rocks through exposure to intense heat such as when stones were used by prehistoric people to Tine a hearth or pit oven.

the hinge portion of a mussel shell where ligaments attached to both valves (halves) of the shell held it together while the animal was living. More durable than thinner parts of the she1l, the umbo survives better in archaeological deposits

a chipped stone tool which was formed through chipping on only one face. Usually made from large flakes, the face opposite the chipped surface is very smooth and flat.

a flake which, without further intentional alteration, is used as a tool to perform some task such as cutting, shaving, or scraping. The utilized flake is recognized by edge damage, that is, tiny flake removals and breakage along the sharp edge resulting from contact with the material being worked.

use of a pressurized jet of water to wash earth through hardware cloth or flyscreen for purposes of recovering cultural debris. This method had advantages over hand screening (see above) in that it is faster and, because the matrix can be more completely broken down to pass through flyscreen, smaller items of cultural debris can be recovered. 
. 